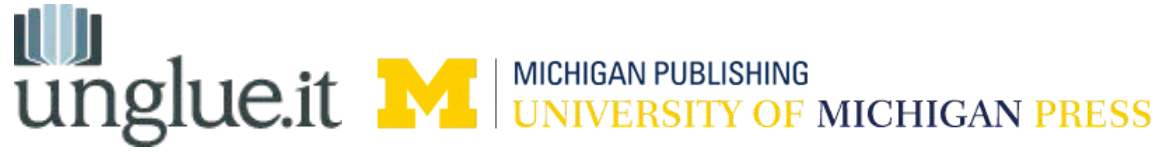

ONLINE SURVEY

In collaboration with Unglue.it, we have set up a survey (only ten questions!) to learn more about how open access ebooks are discovered and used.

We really value your participation-please take part!

\section{CLICK HERE}

An electronic version of this book is freely available, thanks to the support of libraries working with Knowledge Unlatched. $\mathrm{KU}$ is a collaborative initiative designed to make high quality books Open Access for the public good. 

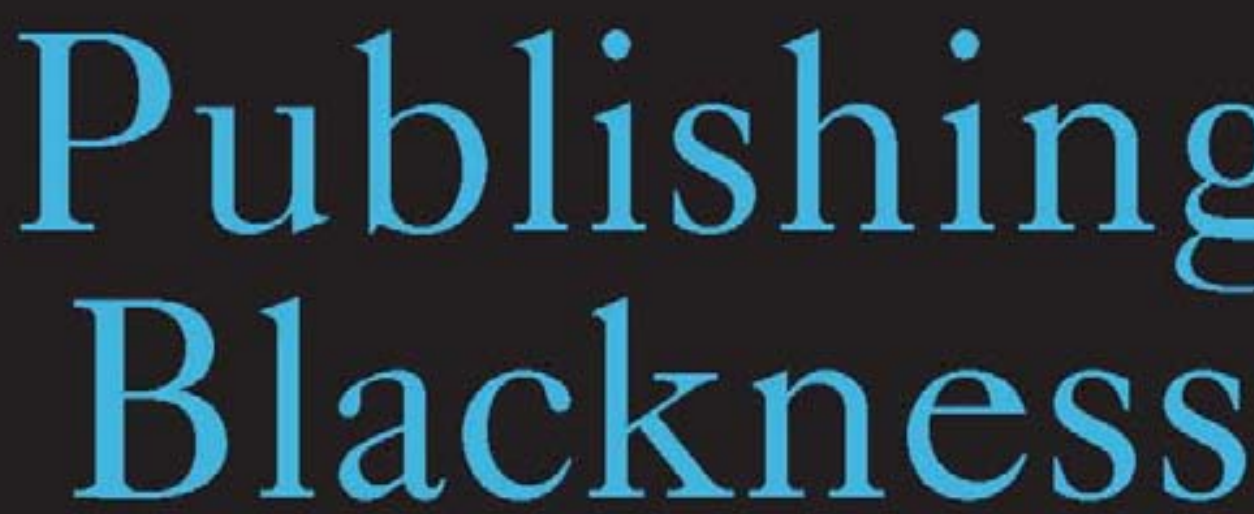

\section{TEXTUAL CONSTRUGTIONS} OF RACE SINGE 1850

Edited by

George Hutchinson and John K. Young 


\section{PUBLISHING BLACKNESS}




\section{EDITORIAL THEORY AND LITERARY CRITICISM}

\section{George Bornstein, Series Editor}

Palimpsest: Editorial Theory in the Humanities, edited by George Bornstein and Ralph G. Williams

Contemporary German Editorial Theory, edited by Hans Walter Gabler, George Bornstein, and Gillian Borland Pierce

The Hall of Mirrors: Drafts \& Fragments and the End of Ezra Pound's Cantos, by Peter Stoicheff

Emily Dickinson's Open Folios: Scenes of Reading, Surfaces of Writing, by Marta L. Werner

Scholarly Editing in the Computer Age: Theory and Practice, Third Edition, by Peter L. Shillingsburg

The Literary Text in the Digital Age, edited by Richard J. Finneran

The Margins of the Text, edited by D. C. Greetham

A Poem Containing History: Textual Studies in The Cantos, edited by Lawrence S. Rainey

Much Labouring: The Texts and Authors of Yeats's First Modernist Books, by David Holdeman

Resisting Texts: Authority and Submission in Constructions of Meaning, by Peter L. Shillingsburg

The Iconic Page in Manuscript, Print, and Digital Culture, edited by George Bornstein and Theresa Tinkle

Collaborative Meaning in Medieval Scribal Culture: The Otho Lazamon, by Elizabeth J. Bryan

Oscar Wilde's Decorated Books, by Nicholas Frankel

Managing Readers: Printed Marginalia in English Renaissance Books, by William W. E. Slights

The Fluid Text: A Theory of Revision and Editing for Book and Screen, by John Bryant

Textual Awareness: A Genetic Study of Late Manuscripts by Joyce, Proust, and Mann by Dirk Van Hulle

The American Literature Scholar in the Digital Age, edited by Amy E. Earhart and Andrew Jewell

Publishing Blackness: Textual Constructions of Race Since 1850, edited by George Hutchinson and John K. Young 


\section{PUBLISHING BLACKNESS \\ Textual Constructions of Race Since 1850}

George Hutchinson and John K. Young, editors

The University of Michigan Press

Ann Arbor 
Copyright $\odot$ by the University of Michigan 2013

All rights reserved

This book may not be reproduced, in whole or in part, including illustrations, in any form (beyond that copying permitted by Sections 107 and 108 of the U.S. Copyright Law and except by reviewers for the public press), without written permission from the publisher.

Published in the United States of America by The University of Michigan Press

Manufactured in the United States of America @ Printed on acid-free paper

$\begin{array}{llllllll}2016 & 2015 & 2014 & 2013 & 4 & 3 & 2 & 1\end{array}$

A CIP catalog record for this book is available from the British Library.

Library of Congress Cataloging-in-Publication Data

Publishing blackness : textual constructions of race since 1850 /

George Hutchinson and John Young, editiors.

pages $\mathrm{cm}$ - (Editorial theory and literary criticism)

Includes bibliographical references and index.

ISBN 978-0-472-11863-2 (hardback) -

ISBN (invalid) 978-0-472-02892-4 (e-book)

1. American literature-African American authors-History and criticism-Theory, etc. 2. Criticism, Textual. 3. American literature-African American authors-Publishing-History.

4. Literature publishing-Political aspects-United StatesHistory. 5. African Americans-Intellectual life. 6. African Americans in literature. I. Hutchinson, George, 1953- editor of compilation. II. Young, John K. (John Kevin), 1968- editor of compilation

PS153.N5P83 2012

$810.9^{\prime} 896073-\mathrm{dc} 23$ 


\section{ACKNOWLEDGMENTS}

Publishing Blackness has passed through several potential versions before settling in its current form. We have been grateful throughout to George Bornstein, for initiating this project for Michigan's Editorial Theory and Literary Criticism Series, and for helping to shepherd the book through the production process. We also thank the volume's contributors, for the depth and range of their insights and for their patience along the way. We have appreciated the questions and objections from the Press's three anonymous reviewers, each of whom helped to make the final product stronger. Finally, we have been lucky to work with Thomas Dwyer and other members of the University of Michigan Press staff, including Christopher Dreyer and Alexa Ducsay. 



\section{CONTENTS}

\section{Introduction}

The Brief Wondrous Life of the Anglo-African Magazine;

or, Antebellum African American Editorial

Practice and Its Afterlives

IVY G. WILSON

Representing African American Literature; or,

Tradition against the Individual Talent

GEORGE HUTCHINSON

"Quite as human as it is Negro": Subpersons and

Textual Property in Native Son and Black Boy

JOHN K. YOUNG

The Colors of Modernism: Publishing African Americans,

Jews, and Irish in the 1920 s

GEORGE BORNSTEIN

More than McKay and Guillén: The Caribbean in

Hughes and Bontemps's The Poetry of the Negro (1949)

IFEOMA KIDDOE NWANKWO

108

Editorial Federalism: The Hoover Raids, the New Negro

Renaissance, and the Origins of FBI Literary Surveillance

WILLIAM J. MAXWELL

Loosening the Straightjacket: Rethinking Racial

Representation in African American Anthologies

GENE ANDREW JARRETT 
VIII CONTENTS

"Let the World Be a Black Poem": Some Problems of Recollecting and Editing Black Arts Texts

JAMES W. SMETHURST

Textual Productions of Black Aesthetics Unbound $\begin{array}{lr}\text { MARGO NATALIE CRAWFORD } & 188\end{array}$

$\begin{array}{ll}\text { Select Bibliography } & 211\end{array}$

$\begin{array}{ll}\text { Contributors } & 215\end{array}$

$\begin{array}{ll}\text { Index } & 219\end{array}$ 


\section{George Hutchinson and John K. Young}

\section{INTRODUCTION}

Ed Bullins's 1971 one-page play, Malcolm: '71, or Publishing Blackness, laments and excoriates the academic domestication of black radicalism, specifically with reference to a white graduate student's request that a black playwright recommend black poets for inclusion in her planned anthology of radical American literature. Whitegirl tells Blackman she was given Blackman's name by Professor Hack, "the white professor who teaches black poetry and aesthetics," hired as a result of student protests for a Black Studies program at the Black Revolutionary Third World City University. "You wouldn't imagine," she tells Blackman, "how terribly, terribly radical and revolutionary this book is going to be! . . . And I was hoping that, if you could collect a section for the Blacks ... I mean the Black poets, of course, well I could meet with you." Blackman cuts her off, asking who her dog Malcolm (barking in the background throughout) is named for. When she replies, "Malcolm X," he gently hangs up the phone. ${ }^{1}$

Central to this interchange is a concern about the cooptation and domestication of black radicalism and black literature, accompanied by implicit worries about textual reproduction and selection in academic scholarship. As Margo Crawford notes in her discussion of Bullins in this volume's closing essay, Malcolm: ' 71 "dramatizes the problem of who frames whom and who collects whom." At the time of the play, textual scholarship was enjoying something of a revival that would last into the $198 \mathrm{os}$. Black literary study, on the other hand, was just taking off on its post-196os expansion with a growing number of newly reprinted texts, often in hardback facsimile form out of Arno Press of the New York Times or in inexpensive paperback under the aegis of the African/ American Library series edited by Charles R. Larson and published by Collier Books. Scholarly editions of African American literature were practically nonexistent. 
With its philological roots in the Bible, medieval scrolls, and Shakespeare's folios and quartos, textual scholarship was slow to come to African American literature, no doubt in part because textual scholarship depended on an academic industry already built up around canonical, white male authors. Groundbreaking editions like the 1969 "genetic text" of Melville's Billy Budd (an Inside Narrative) edited by Harrison Hayford and Merton M. Sealts Jr. could only be justified financially on the basis of a large array of courses in which it might be used in place of a cheaper, even if flawed, edition in a paperback collection of Melville's stories and novellas. The mammoth CEAA-approved editions of the complete works of Hawthorne, Melville, Whitman, and Howells-none of which was finally completed-took decades of work and plenty of money from soonstrapped university presses. They ended in midstream and went out of print as scholarly publishing lost financial support and viability in the course of the 1980 os and after. Indeed, textual scholarship easily appeared out of sync with the French poststructuralist wave sweeping the American academy in the 1970s and 1980s, and generally lost prestige, not to mention market share, in the profession of literary studies as a whole over the last three decades of the twentieth century. ${ }^{2}$ African American literary studies, meanwhile, took an opposite trajectory.

While African Americanist scholarship exploded by the turn of the twenty-first century and, some might argue, contributed in some of its forms to the domestication of black literary radicalism, textual scholars-almost all of them white-lamented that no one seemed to care anymore about what they did. However, as black-authored texts entered the bookstores and the classrooms in expanding numbers, and black literary scholarship became institutionalized, a new interest in issues raised by textual scholars began to appear in African American literary scholarship, and textual scholars began turning to black-authored texts. Certain developments in textual scholarship meshed in interesting ways with central issues in African American literary study. For example, a move away from establishing "authoritative" texts based on an author's initial or final intentions, or a fetishization of "copytext," suited a field in which intentionality could be difficult to determine. ${ }^{3}$ The "broken, coded documents" ${ }^{3}$ of black literary history might be reread and reedited from theoretical orientations focused on broader imaginings of textuality, without authorial intention as a guiding principle. An interest in what Gerard Genette termed the "paratext," including prefaces, typefaces, dust jackets, and eventually what came to be known as the "mate- 
rial text," connected with long-standing concerns in African American studies about the material and institutional contexts of black literature. Similarly, textual scholarship moved toward a greater acceptance of multiplicity in presentations of texts, or what some have termed the "fluid text," and this plausibly connects with what have been regarded as the especially performative dimensions of black literature, what Jennifer DeVere Brody identifies as "the issue of the link (or leak) between black ink and embodied forms of blackness - of being black and black being." ${ }^{5}$

While William L. Andrews would lament in a 1997 essay that "classic African American writers" could not "qualify for complete textual editions in formats comparable to those that are sealing a hallowed place in American literary history for a Harold Frederic or a Charles Brockden Brown," the fifteen years since have witnessed important editions and anthologies of black literature, several produced by contributors to this collection. ${ }^{6}$ At the same time, the growing turn toward digital editions, while often responding brilliantly to the changing circumstances under which texts are and will be archived, edited, and read, also threatens to replay the same tight connections between cost and commercial viability that informed the selection of CEAA editions. The first decade of the twenty-first century has seen important digital editions of William Blake, Dante Gabriel Rossetti, Geoffrey Chaucer, Beowulf, and Willa Cather, among others, but thus far only "smaller" online projects related to African American texts, such as Christopher Mulvey's edition of Clotel. ${ }^{7}$ Whether this trend will continue remains to be seen, but the financial exigencies of digitizing and storing electronic editions do not figure to change in the foreseeable future. While Yale University Press, for example, in coordination with the Frederick Douglass Papers, has produced important new print editions of Douglass's autobiographies during this period, the editorial principles adopted there have tended to reinforce the premises upon which author-centered editions have historically proceeded, what Clayborne Carson, in an overview of his editions of Martin Luther King Jr's papers, has called the "widespread belief among American elites in the notion that Great Men and their ideas alter the course of history." ${ }^{\prime}$ As Carson acknowledges, the material support for his work on King's papers itself relies on this ostensibly outmoded historiography, as do Yale's Douglass editions. Once again, African American literary scholarship finds itself caught between belated inclusion in theoretical approaches to textual scholarship whose foundations are crumbling, on the one hand, and new theoretical visions that turn out to be premised 
on familiar practices of exclusion. We present this volume in the hope of finding different ways of conceptualizing this relationship, both in theory and in practice.

The present collection-this instance of Publishing Blacknessresponds to recent trends in both textual and African Americanist scholarship, with the hopes of relocating this emerging dialogue away from the margins of each field. At the same time, the volume argues that this exchange has long been implicit in each discipline's concern for modes of textual production and reproduction. Indeed, from the white editorial authentification of slave narratives, to the cultural hybridity evidenced in the Harlem Renaissance's interaction of Jewish publishers and "New Negro" authors, to the overtly independent publications of the Black Arts Movement, to the immense commercial power of Oprah's Book Club, African American textuality has consistently revolved around the contests of cultural power inherent in literary production and distribution. Always haunted by the commodification of blackness and by forms of racial surveillance, from the era of slavery to the age of Obama, African American literary production interfaces with the processes of publication and distribution in particularly charged ways. Because the production of racial difference and inequality, as well as the battle against white supremacy that helped produce a black public sphere, has been vitally connected with the rise, and the struggles over control, of American print culture, African Americanist scholarship has the potential to drive textual scholarship in new and provocative directions. As black writers from Hurston to Suzan Lori-Parks and theorists such as Diana Taylor and Fred Moten have pointed out, the mechanisms of publication and archive-building have served racial domination, to such an extent that some black literary expression has attempted to evade traditional Western textual form entirely, embedding itself in slave-thrown pottery in the nineteenth century and in ephemeral material or performative instantiations since. ${ }^{9}$ Such arguments-which may have relevance for other literary traditions as well (one thinks in particular of Native American and Chicano/a studies) - bring into view the shifting boundaries of textual scholarship's very self-definition.

Even if not grounded in terms specific to textual scholarship, African Americanist literary scholarship since its inception has evoked theories of textuality and editorial practice. James Weldon Johnson's 1928 essay "The Dilemma of the Negro Author," for example, fundamentally concerns the material dissemination of black letters in a white supremacist 
society, what Johnson terms "a special problem which the plain American author knows nothing about-the problem of the double audience. ... The moment a Negro writer takes up his pen or sits down to his typewriter he is immediately called upon to solve, consciously or unconsciously, this problem of the double audience." ${ }^{10}$ Similarly, the trope of the "talking book," influentially explored by Henry Louis Gates Jr. in The Signifying Monkey and beyond, suggests a sometimes ambivalent yet very productive relationship between print and oral expression in the African American literary tradition. A distrust of the printed word, especially when it concerns or presumes to represent black experience (even if produced by writers of African descent), is written into much black literature after World War II. As Gates asks, "What did/do black people signify in a society in which they were intentionally introduced as the subjugated, as the enslaved cipher? Nothing on the $x$ axis of white signification, and everything on the $y$ axis of blackness." 11 This version of a double audience, in which a white readership threatens to zero out the paradoxically limited plenitude of a black representational scheme, reframes Johnson's dilemma in ways that express the particular feedback loop between textual production and reception for African American literature. What has editorial theory or textual scholarship to do with African American literature? Everything.

And vice versa. The mainstream of African American literary study has, arguably, been a wrangling over the relationship of the literary text to its multiple determinations of editorial mediation, packaging, oral antecedent, strategic duplicity, relation to lived experience, ambiguous authorship, canonization, and methods of marketing that affect the material presentation of the text, and thus the text itself. As Houston A. Baker Jr. famously concludes, in a discussion of the Trueblood episode in Invisible Man, "To examine the status of black expressiveness as a commodity, then, is to do more than observe, within the constraints of an institutional theory of art, that the 'art world' is a function of economics. In a very real sense, the entire sum of Afro-America's exchange power has always been coextensive with its stock of expressive resources." ${ }^{12}$

Publishing Blackness explicitly addresses the issues raised by putting these disciplines in a mutual exchange. The volume charts major issues and trajectories, from decisions concerning the presentation of particular texts to the book-form republication of works previously published in serial form for black-owned periodicals, to issues of archival preservation, to questions of canonization, to the dissemination of texts that 
originally had a strong performative dimension, and more recent experiments involving collaborations between black poets and musicians or visual artists. In assembling the essays that follow, we have aimed not to be comprehensive but to present provocations and instigations for further work in this vital area of literary scholarship. We very much agree with Leon Jackson's recent call "to read both the outsides as well as the insides of texts and theorize the mediatory connections between the two," and view this collection as another step in a period of slow but steady crossfertilization between these disciplines over the last several years. ${ }^{13}$

At the same time, this collection takes advantage of its grounding in African American literary history to question the premises and methods of textual scholarship itself. While editorial theory in recent years has emphasized the social dimensions of textual production, this focus has generally not been extended to matters of race (with some notable exceptions). From the problematic and productive hybrid interactions between black writers and white editors and publishers to the constitution of the page itself with black letters on a white background (though with occasional texts that self-consciously foreground, by resisting, this practical norm), there are numerous editorial issues that may change significantly once race is taken into account. In her lecture "Home," Toni Morrison presents an example of one such difference in her discussion of Beloved's last sentence, "Certainly no clamor for a kiss." As Morrison explains, her editor at Alfred A. Knopf, Robert Gottlieb, "had suggested an alteration in the language of the sentence," leading Morrison eventually to revise her original version with the closing word "kiss," and prompting outrage in a friend of Morrison's who had seen the novel's manuscript. Morrison concludes, "Actually, I think my editor was right. The original word was the 'wrong' word. But I also know that my friend was right: the 'wrong' word, in this case, was also the only word. Since language is community, if the cognitive ecology of a language is altered, so is the community." ${ }^{14}$ The social and racialized dimensions of language, and the commercial and cultural dimensions of Morrison's response to her editor's suggestion, generate precisely the kinds of questions that the essays in this volume address: how to understand relationships between texts and communities of readers, and how to chart the material production of those texts and the implicit construction of their readerly communities.

African Americanist criticism has always involved textual scholarship, whether that moniker has been used or not. Textual scholarship's primary relationship to African American studies derives from its focus 
on historicizing the processes of textual production, which grounds in material and social detail the ways in which authorial and publishing processes reflect and/or struggle against the social, cultural, and political systems working in the background of a work's production. While most African Americanist research has focused at this level of analysis, the reproduction of African American literature has tended to take the texts' material history lightly, as the imperative of simply getting out-of-print texts back into circulation-specifically as African American literaturehas been the priority. This in itself indexes the force of the color line in the production and reproduction of work by African American authors. And yet questions about how books are edited, published, marketed, distributed, repackaged, and anthologized have been raised from very early in the history of African American literature. They are ultimately questions about how books function as evidence for the ways in which "race" has operated as a social category. The editorial theorist Paul Eggert concludes of the broader relationship between editorial scholarship and the social sphere: "But of course, until the bibliographic work is done, the fine-grained ways in which a literary text can be shown to duplicate or resist or reformulate the ideological cross-currents of its period are not reliably available for close inspection, although ungrounded generalisations may always be entertained." ${ }^{15}$ In the case of African American literature, such bibliographic work might entail examining a book's various covers and other paratextual features; comparing its manuscript and published versions in relation to the choices mandated by editors, publishers, or other agents; investigating the advertised images of authors and their books; charting a work's popularized format, in paperback editions or in anthologies; and many other avenues.

Spurred by Jerome McGann's work in 1980s and 1990s-especially in A Critique of Modern Textual Criticism (1983), The Textual Condition (1991), and Black Riders (1993)-editorial theorists shifted toward a socialized conception of authorship, relocating authors within a broader spectrum of participants in the process of textual production, alongside editors, publishers, printers, and various other associated agents. Editorial work thus became not a pursuit of an "ideal" or "definitive" edition that would reflect an author's original or final intentions, but rather a matter of reproducing a work's first published edition, as a window into the social contexts behind the process of making the work public. The choice between an intentionalist or materialist editorial orientation is more, or at least differently, complicated in the case of many black writ- 
ers, given the actual and/or perceived circumscriptions on their agency, both at the immediate level of composition and revision and in the wider sphere of aesthetic expressiveness.

While the story of the McGannian revolution in editorial theory will be familiar to those readers approaching this collection from that vantage point, it is worth rehearsing briefly for those encountering the essays here from a background in African American studies. (Like all such narratives, this one necessarily reduces and simplifies a complex history; readers interested in more detailed accounts should consult the Select Bibliography at the end of this volume.) The "modern textual criticism" that McGann began to critique in the early 1980 os, frustrated by his experiences editing Byron, was grounded in earlier twentieth-century work from W. W. Greg, Fredson Bowers, and G. Thomas Tanselle. This editorial school defines its choice of copy-text, and thus its guiding sense of textuality, in terms of final authorial intention, often using such intention as a regulative ideal, in the absence of direct evidence of an author's wishes, but still premised on what an editor perceives the author's intentions to have been. As Tanselle concludes in his key 1976 essay, "The Editorial Problem of Final Authorial Intentions," an editor is "pledged to print only the author's words." Even in cases where an editor's judgment leads to a different text than the one ordinarily perceived as "final," the "justification is that the reading is 'final' in terms of his [the editor's] view of the work as an organic whole." ${ }^{16}$ For editorial theorists, the controversy surrounding Hans Walter Gabler's 1984 "synoptic" edition of Ulysses revolved around the lack of any single document or set of documents Joyce had "authorized"; rather, Gabler determines what he perceives Joyce's intentions to have been in an ideal world (which of course was far from the case in the actual circumstances of production). Gabler's Ulysses is therefore, for McGann, the first instance of postmodern editing. ${ }^{17}$

McGann's critique of the Greg-Bowers-Tanselle orientation first finds statements such as Tanselle's above to be internally incoherent, and, more important, privileges a work's first publication as most expressive of the history of its production, rather than seeking a return to a version desired by an author but interfered with on the way to the public. For McGann, Jack Stillinger, and others, authorship becomes an inherently social process, as reflected by the messy realities of publication, and so their approaches to editing derive from this materialist stance. Rather than restoring Hurston's Dust Tracks on a Road to its manuscript version, 
for example, before the cuts and revisions mandated by Lippincott in the midst of World War II, a McGannian editor would prioritize the book's initial publication, finding in the frustration of Hurston's intentions rich evidence for the social circumscriptions of black authorship in the 1940s.

The last several years, however, have witnessed something of a postMcGannian shift within editorial theory, toward a more comprehensive sense of textuality as always oscillating between intentionalist and materialist instantiations. In such works as Peter Shillingsburg's Resisting Texts (1997), Paul Bryant's The Fluid Text (2002), Sally Bushell's Text as Process (2009), and Paul Eggert's Securing the Past (2009), there emerges a growing preference for privileging the work as a collection of versions, and thus for editing multiple iterations, rather than focusing primarily on a particular text emanating from an author's ideal or a publisher's product. As Bryant explains, "The very nature of writing, the creative process, and shifting intentionality, as well as the powerful social forces that occasion translation, adaptation, and censorship among readers-in short, the facts of revision, publication, and reception-urge us to recognize that the only 'definitive text' is a multiplicity of texts, or rather, the fluid text." ${ }^{18}$ This kind of editorial approach seems especially well suited for much African American literature, whether it is aimed at multiple audiences as part of the struggle to resist being framed as "only" black while also carving out a distinct aesthetic space from which an authentically black cultural perspective could develop, or is aimed deliberately at a black audience with an emphasis on process and performance as well as communal collaboration rather than textual fixity and reproducibility. The former tensions are clearly in play in the career of Jean Toomer, for instance, who published much of the poetry and fiction that would make up Cane in a variety of modernist journals, several of which (such as Double Dealer or $S_{4} N$ ) were not marked as distinctly "Negro," and who yearned to be known, in reviews and advertisements for his work, simply as "American." The latter tensions are endemic in the Black Arts Movement, as James Smethurst and Margo Natalie Crawford point out in this book.

Similarly, the problem of how to edit the first British and three later American editions of William Wells Brown's Clotel (or Clotelle, or Miralda, as it was alternately titled) derives in part from Brown's flight to London following the passage of the Fugitive Slave Act in 1850, just as Lippincott's removal of "whole chunks" of Hurston's Dust Tracks appears alternately to contemporary critics as either Hurston allowing her edi- 
tor to eliminate any "overt statements . . . that might have been viewed as inflammatory," or as Hurston enacting a "duping" strategy in which the revised passages subvert their intended editorial meanings. ${ }^{19}$ Editors selecting one of these editions as a copy text, or determining the relationship between a main text and its annotated variants, will require a nuanced sense of American racial history in order to parse out either authorial intention or the social circumstances surrounding initial publication, just as African Americanists interpreting such works should realize the editorial choices (or lack thereof) informing the contemporary reprints on which they base their readings.

The historical difficulties of residing outside of a rigid black/white system, or the kinds of imaginary classificatory structures that both make cultural practices like passing possible even while the principles upon which they ostensibly rest are undercut by the possibility of passing: these are the senses of history that have largely defined African Americanist studies, and with which textual scholarship would profitably engage. In his recent What Was African American Literature? (2011), Kenneth W. Warren analyzes the overlay of history and contemporary perspective in terms of repeated and "oversimplified" emphases on racism.

Rather, what needs getting at is what follows when the problem of racism has become a problem of history. For once racism is described as a problem of how we understand and acknowledge the power of history, "color blindness" becomes something other than pretending not to notice conventional marks of racial difference even as one makes important decisions based on that difference. Rather, "color blindness" turns out to be a kind of blindness to the presentness of the past, a refusal to see that people can still be victimized by the past, and that the past can be victimized by the present. $^{20}$

Whether or not one ultimately agrees with Warren's provocative thesisthat the gradual disintegration of Jim Crow society will consequently mean the end of an African American literature that has defined itself in relation to the creation of racial equality-Warren's argument highlights the simultaneously productive and problematic relationship between black aesthetics and black politics, and the vision of history that derives from that intersection. The essays in this volume are similarly situated, 
for editing-both in theory and in practice-turns inevitably on the "presentness of the past," by asking how to represent a work's historical processes and versions to present (and future) readers.

This collection ended up with a notable emphasis on anthologization, which was not the editors' initial intention, yet this emphasis is symptomatic of the structurally central role of anthologies in the rise and shifting definitions of "black literature," closely connected with social and political goals. Bringing attention to black literature as such, and developing an audience for literature by African Americans and others of African descent, entailed collecting different varieties of it and presenting it in aggregate form, in the process willy-nilly developing a "canon" of black literature distinct from other literatures, even in the case of anthologies, such as Countee Cullen's Caroling Dusk, that did not believe in such a concept as "Negro poetry." In the course of the twentieth century the notion of African American literature as a coherent category decisively won out, most decisively in fact after the time when, according to Warren's argument, "African American literature" ended-that is, after the passage of civil rights legislation that spelled the end of formal segregation. The legal supports of racial segregation fell before an assault that was both "integrationist" and nationalist to varying degrees, self-consciously defined as the movement of a people with a long history, and with a future. "I may not get there with you," Dr. King famously said, "but we as a people will get to the promised land." Thus a form of what Darby English, in the context of African American visual art, has termed "black representational space" became institutionalized-along with black studies itself-as never before just as certain forms of legally sanctioned segregation died. As Ivy Wilson points out in this book, the archival turn and emergence of such series as the Oxford Collected Black Writing Series edited by Henry Louis Gates Jr. may signal "a certain state in the institutionalization of African American Studies that no longer requires an immediate political concern or social movement to authorize its lines of critical inquiry." This insight might be of considerable theoretical significance to an understanding of the history of textual scholarship as a whole.

The archival turn to which Wilson alludes (which would be impossible without antecedents in the field of collecting and library scienceArthur Schomburg's collection acquired by the New York Public Library in the 1920s, the acquisition of the Moorland and Spingarn collections at Howard University, the development of the James Weldon Johnson 
Memorial Collection in the late 1930s and 1940s, and other such endeavors) has been an enormously productive development as well as one that required some attempt at the definition of boundaries, and it followed upon African Americanist criticism from the Black Arts Movement forward (by Larry Neal, Stephen E. Henderson, Addison Gayle Jr., Baker, Gates, and many others) that was largely defined by the goal of distinguishing what made "black literature" black, not just sociologically but formally, ethically, and thematically. Examining the changing notions of what challenged editors of black literature anthologies and book series over the course of the twentieth century therefore, it would seem, ends up being a major issue for an investigation of the "textual production of race" suggested in this book's subtitle.

Also significant as one examines anthologies and reprint series or new editions is the oblique relationship between nationality and race. While the category "black" challenges national boundaries, the converse is also true: an author who is "black" or "Negro" in one country may not be so considered in another, as Langston Hughes sadly discovered on his first trip to Africa when people of present-day Ghana whom he encountered told him he was a white man. This did not, of course, prevent Hughes from continuing to identify with Africans as Negro, or black-a choice, however involuntary in the American context, without which the canon of African American poetry might look much different than it does today. If Caribbean writers like Claude McKay, Eric Walrond, and Paule Marshall have entered the canon of African American literature, destabilizing the enclosure of "African American" as a subcategory of "American" literature, so has the attempt to internationalize American understandings of blackness destabilized that very category, most notably in the midcentury anthology none other than Hughes coedited with his close friend Arna Bontemps, discussed by Ifeoma Kiddoe Nwankwo in this book. One might notice intriguing tensions as well as connections that surface between the various chapters of this book as symptomatic of tensions, ambiguities, and ambivalences about the very notion of "black literature" in the history of the concept's twentieth-century career, and its currently debated status among scholars, poets, novelists, and playwrights.

The nine essays that follow are organized both chronologically and thematically, with the guiding questions outlined above appearing across a range of periods and genres. Ivy G. Wilson focuses on antebellum print culture in relation to Thomas Hamilton's Anglo-African Magazine, which 
he conceived of as a space in which African Americans could "speak for themselves." Turning from the fraught process of production for blackowned periodicals in this period to three of the magazine's most prominent contributors-Martin R. Delany, Frances E. W. Harper, and James McCune Smith-Wilson seeks to contextualize these authors within the discursive field of Hamilton's magazine, thus recentering contemporary recoveries of nineteenth-century African American literature away from writers considered in relative isolation, in order to better gauge the "multitudinous and sometimes contradictory ideas of these writers at specific moments." George Hutchinson's essay begins with an invocation of recent "Post-Black" (which is not to say postrace) artists' resistance to enclosure in "black representational space" and then examines curiously related efforts of New Negro authors to evade racial enclosure. Subsequent historical and editorial approaches to the Harlem Renaissance, he argues, tend to reinscribe a majority/minority distinction that they resisted, that seemed to them related to a Jim Crow ordering of the literary field. In the first of several analyses of anthologization, Hutchinson considers Countee Cullen as a case study, before turning to "the paratextual elements and bibliographic codes that help shape a text's reception," here attuned to Cullen once more and to Nella Larsen's Passing. Essays by John Young and George Bornstein orient themselves toward authorpublisher interactions between the 1920 s and 1940s, with Young examining the ethical implications of Richard Wright's revisions to Native Son and Black Boy (American Hunger), both made at the behest of his Harper Bros. editor and the Book-of-the-Month Club. Bornstein considers several exemplary works of the New Negro Renaissance within the field of their publishers' avant-garde lists, which typically included works by Irish and Jewish authors as well, thus creating a kind of countermodernism to that produced by more established (and Anglo-Saxon) American houses.

Ifeoma Kiddoe Nwankwo investigates the politics of anthologizing in the case of Langston Hughes and Arna Bontemps's 1949 Poetry of the Negro, situating that unique anthology in relation to earlier models. Nwankwo's reading of the Hughes and Bontemps first edition raises the question of what constitutes "Negro" poetry: is the racial identification of the author the constitutive factor, or is the textual subject rather the primary consideration? Noting the slippage in The Poetry of the Negro between poetry "by" Negroes and poetry "of" Negroes coming from what are euphemistically termed "tributaries" (meaning white Ameri- 
cans) and then, even more dramatically, the conceptual complications that ensue from the inclusion of poetry by Caribbean poets of any racial designation and on any subject (the Caribbean being a "Negro" space by implicit definition), Nwankwo positions this midcentury anthology against contemporary interests in Black Atlantic, diasporic, and transnational blackness. Notably, in a later edition of the anthology, Arna Bontemps deleted the entire Caribbean section. It seems that what counts, textually, as black has never been certain.

Hughes also appears in William J. Maxwell's contribution, but here as the subject of the FBI's decades-long surveillance of African American authors, in what Maxwell terms the Bureau's "shaping entanglement with Afro-modernist writing." In more than a few cases, black authors wrote with the awareness of an interpretive community of G-men bent on making cases. This shadow presence within the literature of the $\mathrm{Ne}-$ gro Renaissance, the longer New Negro movement, and after has importantly defined the FBI's cultural presence; and the effects of "editorial federalism" on black writers from composition and revision through publication and beyond opens new possibilities for further research into the production of African American literature through much of the twentieth century.

Gene Jarrett and James Smethurst in the next two essays reflect on their own editorial choices with respect to anthologies currently under way. After analyzing the ideologies implicit in earlier anthologies, in which the rationale for anthologization is to "represent the race," thus screening out what he has elsewhere termed "anomalous texts," particularly those without black characters, Jarrett positions his own Alternative Reader of African American literature (2006) and his in-progress Blackwell Anthology of African American Literature in terms of contemporary readers (both mainstream and academic) who may be "awaiting their own disarticulation from the straightjacket of racial authenticity and representation in African American political history." Can the category African American Literature, he implicitly asks, include texts that do not represent African Americans except in terms of the one-drop rule as applied to the authors of such texts? What constitutes a black text?

The volume's concluding essays, by Smethurst and Margo Natalie Crawford, turn to the presentness of the recent past, investigating the material forms in which Black Arts texts reached their publics. Smethurst faces the challenge of how to represent those forms in composing (with his collaborators Sonia Sanchez and John Bracey) a Black Arts anthol- 
ogy. Observing a privileging of "process over product" in many Black Arts works, he asks how one might produce an edition of such contingent textual forms without endowing them with a false historical stability. Based on a "performance ethos in which artist, work, and audience are intimately bound" in the common question of "what made a text 'Black," Black Arts texts in Smethurst's account compel an approach to anthologizing that is ultimately focused on classroom use, growing out of the necessity all teachers of the movement have faced in assembling their own quasi-anthologies to represent this period.

In a more intensive analysis of Black Arts Movement challenges to Western textual practices, Crawford scans a range of efforts to produce a "Black Book" in the course of the twentieth century, coming to focus on close readings of the paratexts of Black Arts pamphlets and magazines and the inimitable text/image production by Amiri Baraka and Fundi Abernathy, In Our Terribleness, the title page for which was a mirror with the title printed on it. Crawford demonstrates the oppositional status of such works as textual objects: Black Arts material texts, she concludes, "were the textual performance of the antitext, the performance of writing and producing books that would be too action-oriented to be held as a precious object of highbrow capital." In her coda, Crawford adds, appropriately for our own purposes in introducing the book you are now holding, "The Black Arts impulse to make art that defied the dominant norms was tied to the impulse to make art that was too excessive to be contained in books."

Far from the last word on this field, this collection will, we hope, stimulate further investigations, archival research, classroom questions, and perhaps even new forms of anthologies, as these two rich and diverse disciplines continue to engage each other. Many topics and problems fall outside the scope of the essays here, including (but certainly not limited to) interactions between African American literature and texts produced by other "minority" authors, from the early days of the republic to the present; the efficacy of more historically grounded editorial approaches to past black literary works, versus the kinds of fluid textuality made possible by advances in the digital humanities; the packaging and distribution of mass-market African American writers, from Iceberg Slim to Zane; or the material forms of black cinema. As early twentyfirst-century humanities scholarship continues the project of "laying equal claim to the Fourth of July," in the philosopher Charles W. Mills's 
words, the material forms of American racial history should continue to be revisited and reproduced, even as the means of those returns are reconceived from both sides of the dialogue between textual and African Americanist scholarship. ${ }^{21}$

Notes

1. Ed Bullins, Ed Bullins: Twelve Plays and Selected Writings, ed. Mike Sell (Ann Arbor: University of Michigan Press, 2006), 135-36.

2. On the CEAA and the current MLA Committee on Scholarly Editions in relation to poststructuralist literary theory, see Peter Shillingsburg, Resisting Texts: Authority and Submission in Constructions of Meaning (Ann Arbor: University of Michigan Press, 1997), chapter 5.

3. As early as 1983, in A Critique of Modern Textual Criticism (Chicago: University of Chicago Press), Jerome J. McGann would note the "nonscriptural level of authority" in The Autobiography of Malcolm X, observing, "An editor who came to deal with this work might be tempted to say, simply, that Alex Haley is the principal authority for the 'words' while Malcolm X is the authority for the material and 'ideas.' Needless to say, it does not require much imagination to realize the problems which would await an approach based upon such distinctions" $(85,85-86)$. On the other hand, this is the only African American text to appear as an example in Critique (aside from a passing reference to Eldridge Cleaver's Soul on Ice in the same paragraph) and is bracketed by discussions of Bulwer-Lytton, John Ashbery, Marianne Moore, and Auden. Even D. C. Greetham's 1999 study, Theories of the Text (Oxford University Press), so exhaustive in its exemplary detail that the name index stretches across twenty pages, includes nary a mention of Frederick Douglass, Zora Neale Hurston, Ralph Ellison, or any other African American literary example.

4. Fred Moten, "Black Op," PMLA 123 (2008): 1743.

5. On paratext see Gerard Genette, Paratexts: Thresholds of Interpretation, trans. Jane E. Lewin (Cambridge: Cambridge University Press, 1997). Jennifer DeVere Brody, "The Blackness of Blackness ... Reading Invisible Man," Theatre Journal 57 (2005): 681.

6. William L. Andrews, "Editing 'Minority' Texts," in The Margins of the Text, ed. D. C. Greetham (Ann Arbor: University of Michigan Press, 1997), 50.

7. See Christopher Mulvey, "Liberating an African American Text: Editing Clotel for an Electronic Century," in Critical Voicings of Black Liberation: Resistance and Representations in the Americas, ed. Kimberly J. Phillips, Hermine D. Pinson, Lorenzo Thomas, and Hanna Wallinger (Münster: Lit, 2003).

8. Clayborne Carson, "Editing Martin Luther King, Jr.: Political and Scholarly Issues," in Palimpsest: Editorial Theory in the Humanities, ed. George Bornstein and Ralph G. Williams (Ann Arbor: University of Michigan Press, 1993), 314.

9. Michael A. Chaney discusses the pottery of David Drake ("Dave the Potter") in Fugitive Vision: Slave Image and Black Identity in Antebellum Narrative (Bloomington: Indiana University Press, 2009), 176-208. On a theorization of the relationship of performativity as improvisation to black aesthetics and language, see Fred Moten, In the 
Break: The Aesthetics of the Black Radical Tradition (Minneapolis: University of Minnesota Press, 2003). In The Archive and the Repertoire: Performing Cultural Memory in the Americas (Durham: Duke University Press, 2003), Diana Taylor argues for "embodied memory" in performance as offering alternative perspectives on historical experience in the Americas compared to, or in concert with, those derived from the written archive, especially for those shut out from positions of power.

10. James Weldon Johnson, “The Dilemma of the Negro Author," in The New Negro: Readings on Race, Representation, and American Culture, 1892-1938, ed. Henry Louis Gates Jr. and Gene Andrew Jarrett (Princeton: Princeton University Press, 2007), 378.

11. Henry Louis Gates Jr., The Signifying Monkey: A Theory of African-American Literary Criticism (New York: Oxford University Press, 1988), 47.

12. Houston A. Baker, "To Move without Moving: Creativity and Commerce in Ralph Ellison's Trueblood Episode," in Black Literature \& Literary Theory, ed. Henry Louis Gates Jr. (New York: Routledge, 1990), 243.

13. Leon Jackson, "The Talking Book and the Talking Book Historian: African American Cultures of Print-The State of the Discipline," Book History 13 (2010): 293.

14. Toni Morrison, "Home," in The House That Race Built, ed. Wahneema Lubiano (New York: Random House, 1997). Both quotations in this paragraph appear on page 8 .

15. Paul Eggert, Securing the Past: Conservation in Art, Architecture and Literature (Cambridge: Cambridge University Press, 2009), 161.

16. G. Thomas Tanselle, "The Editorial Problem of Final Authorial Intention," in Textual Criticism and Scholarly Editing (Charlottesville: University Press of Virginia, 1990). Both quotations in this paragraph appear on page 71.

17. Jerome McGann, "Ulysses as a Postmodern Work," in Social Values and Poetic Acts: The Historical Judgment of Literary Work (Cambridge: Harvard University Press, 1988).

18. Paul Bryant, The Fluid Text: A Theory of Revision and Editing for Book and Screen (Ann Arbor: University of Michigan Press, 2002), 2.

19. Valerie Boyd, Wrapped in Rainbows: The Life of Zora Neale Hurston (New York: Scribner, 2003), 357, 360; and Trudier Harris-Lopez, South of Tradition: Essays on African American Literature (Athens: University of Georgia Press, 2002), 66. See also Claudine Raynaud, "Rubbing a Paragraph with a Soft Cloth'?: Muted Voices and Editorial Constraints in Dust Tracks on a Road," in De/Colonizing Subject: Politics and Gender in Women's Autobiography, ed. Julia Watson and Sidonie Smith (Minneapolis: University of Minnesota Press, 1992).

20. Kenneth W. Warren, What Was Black Literature? (Cambridge: Harvard University Press, 2011), 85-86. Warren quotes from Judith Stein, "Of Mr. Booker T. Washington and Others': The Political Economy of Racism in the United States," in Renewing Black Intellectual History: The Ideological and Material Foundations of African American Thought, ed. Adolph Reed Jr. and Kenneth W. Warren (Denver: Paradigm Publishers, 2010), 19.

21. Charles W. Mills, Blackness Visible: Essays on Philosophy and Race (Ithaca: Cornell University Press, 1998), 200. 


\author{
Ivy G. Wilson
}

\title{
THE BRIEF WONDROUS LIFE OF \\ THE ANGLO-AFRICAN MAGAZINE
}

\author{
Or, Antebellum African American \\ Editorial Practice and Its Afterlives ${ }^{1}$
}

On December 6, 1856, the Provincial Freeman and Weekly Advertiser ran James Monroe Whitfield's "Prospectus of the Afric-American Quarterly" advertising a future periodical that he hoped would "enter the arena of public literature, to exhibit the intellectual capacities of the negro race, and vindicate them before the world." ${ }^{2}$ In the wake of his attendance at the National Emigration Convention of the Colored People of North America in 1854 and 1856, Whitfield circulated an advertisement announcing that the convention delegates had authorized the publication of a "Quarterly Periodical devoted to the general interest of the colored people."3 Enumerating the various domains in which the interests of African Americans had been compromised such as the "wicked legislation," "the American government," and the "Word of God," Whitfield maintained that "any class of community that fails to wield" the potent power of the press will "always be depreciated and undervalued in the public imagination." ${ }^{4}$ Conceptualized as a "preeminent Literary work, for circulation both at home and abroad," the Afric-American Quarterly Repository was intended to contain between 160 and 200 octavo pages and be embellished with fine steel engravings of "distinguished negro[es]." Featuring both U.S. and Haitian authors, it would have articles written in English and French. Whitfield himself would act as senior editor, joined by eight corresponding editors-among them Martin R. Delany, James Theodore Holly, William C. Monroe, Mary Ann Shadd (Cary), and Mary E. Bibb.

But Whitfield's wished-for journal was a nonstarter, and the fate of the journal reveals the dilemmas and difficulties of publishing-including 
printing, editing, and subscriptions - that made black periodicals such a tenuous venture in the nineteenth century. Although he was an important figure in the debates regarding emigrationism, Whitfield's principal engagement with the world of publishing consisted of his experience as a poet, in venues such as Frederick Douglass's newspapers and with James S. Leavitt, a small Unitarian outfit that brought out his only volume of poetry in 1853. If Whitfield's call for a dual-language periodical seemed grandly ambitious for someone with little apparent editorial experience, then the aspirations of Thomas Hamilton to start a magazine might seem to have a greater chance of succeeding. Hamilton, who had spent the greater part of his professional life in publishing, had similar wishes to start a magazine that specifically focused on the historical condition and artistic contributions of U.S. blacks.

While recent work by Todd Vogel has reexamined the black press, and Elizabeth McHenry has analyzed black reading communities, the historical and theoretical meanings of African American editorial practices have remained relatively understudied. ${ }^{6}$ By focusing on the specific periodical type of the magazine I use Hamilton's Anglo-African Magazine to stage an analysis of the genealogies of African American editorial practices. In the first part of the essay, I take up Hamilton's history editing and publishing contemporary writers. In the second part, I focus on three figures centrally associated with the Anglo-African MagazineDelany, Frances Ellen Watkins Harper, and James McCune Smith-to unveil some of the lines of critical inquiry that have undergirded the textual scholarship of recent editorial endeavors specifically involved with reprinting projects. In what follows, I examine the publishing initiatives of Hamilton less to formulate a theory of African American editorial practices per se than to interrogate what some of the contemporary practices related to the "archival turn" might mean to current theories of African American studies.

"The requisite editorial matter": The Emergence of the Anglo-African Magazine

While topics such as temperance, religion, and appearance were frequent mainstays, slavery and black equality were the central focus of nearly every antebellum African American periodical. When Douglass launched The North Star (1847-51), he introduced the paper with a prospectus an- 
nouncing his objective: "The object of The North Star will be to attack slavery in all its forms and aspects; advocate Universal Emancipation; exact the standard of public morality; promote the moral and intellectual improvement of the colored people; and to hasten the day of freedom to our three million enslaved fellow countrymen." W Willis A. Hodges's The Ram's Horn, an abolitionist paper out of Williamsburgh, New York, ran for three years between 1847 and 1850, reaching a peak circulation of $2,500 .{ }^{8}$ While every paper advocated the abolition of slavery, there was a wide divergence on whether African Americans should leave the United States altogether, remain isolated in segregated communities, or strive for integration. The Aliened American (1853-54), based in Cleveland, Ohio, and Mary Ann Shadd's Provincial Freeman (1853-57), published in Windsor, Ontario, Canada, championed integration. In contrast, Henry Bibb argued for keeping black communities protected and isolated from whites in his paper, Voice of the Fugitive, while John B. Russwurm, in wrestling control of Freedom's Journal from Samuel Cornish, turned the angle of the paper to one that decidedly advocated that blacks should leave the United States for Africa.

While African Americans could be found within the pages of white-edited periodicals, black periodicals pressed the call for selfrepresentation as an urgent if not necessary responsibility. "We wish to plead our own cause," reads the editorial statement of Freedom's Journal- "Too long have others spoken for us. Too long has the publick been deceived by misrepresentations, in things which concern us dearly ...."' After Freedom's Journal and The Rights of All, Samuel Cornish became editor of the short-lived The Weekly Advocate (1837-1837), where he stated in the first issue to his black readership that the paper was "their paper, in every sense of the word ... devoted particularly to our own interests-conducted by ourselves, devoted to our moral, mental and political improvement." ${ }^{\prime 0}$ And Thomas Hamilton pronounced a similar mandate when he maintained in the inaugural issue of the Anglo-African Magazine that African Americans should "speak for themselves; no outside tongue, however gifted with eloquence, can tell their story; no outside eye, however penetrating, can see their wants; no outside organization, however benevolently intended, nor however cunningly contrived, can develop the energies and aspirations which make up their mission." ${ }^{11}$ After years in the publishing industry, Hamilton would take up this mission again when he began laying the groundwork for his magazine.

Sometime in 1858, Hamilton began distributing copies of his "Pro- 
spectus of the Anglo-African Magazine" to promote the new publication that he would edit. The prospectus was a $19 \mathrm{~cm} \times 14 \mathrm{~cm}$ single-sheet flyer, small enough that it could have been an insert in nearly any publication. He enumerated eight primary objectives of the magazine, among them providing a forum "for the rapidly rising talent of colored men in their special and general literature," and announced that the first issue of an octavo magazine of thirty-two large pages would appear in January 1859 and feature a portrait of Alexander Dumas. ${ }^{12}$ When we recall that Whitfield had hoped his "Afric-American Quarterly Repository" would be something on the range of 160 to 200 pages, we begin to see the almost impossible ambition of his proposal. In an order of scale, the material costs of Whitfield's Afric-American Quarterly Repository would have been at least five times as much as Hamilton's Anglo-African Magazine. Yet, whereas Whitfield hoped to price his quarterly at seventy-five cents, Hamilton sought one dollar for twelve issues.

Hamilton's prospectus itself is a compelling document for what it reveals about the black publishing industry in New York. The flyer was printed by John J. Zuille, whose business was located at 396 Canal Street in New York City. Zuille was active in black politics throughout the century from the antebellum period (founding the New York stop of the Underground Railroad, for example) and served as a delegate at the State Labor Convention for blacks during Reconstruction. ${ }^{13}$ While scholars have a relatively broad picture of the numerous antebellum African American newspapers that existed and, to a lesser extent, corresponding information about their editors and publishers, we still have comparatively little information about African American printers and binders. Zuille was early engaged in African American publishing, having been the printer for the Colored American, a four- to six-page weekly newspaper edited by Samuel Cornish, Phillip A. Bell, and Charles Bennett Ray. In his brief sketch of Zuille in The Rising Son: or, The Antecedents and Advancement of the Colored Race (1873), William Wells Brown described Zuille as a "practical printer" who "showed mechanical skill that placed him at once amongst the ablest of the craft." ${ }^{14}$ Zuille's printing house was in the vicinity of Hamilton's own editorial office at 48 Beekman Street, which also served as the Office of the American Abolition Society, located in an area that was then known as Printing House Square. ${ }^{15}$ The same year that Zuille printed the prospectus for Hamilton's Anglo-African Magazine, he also printed a short four-page document, probably originally intended as a pamphlet, that consisted of a preamble and constitution for the Af- 
rican Civilization Society, of which Henry Highland Garnet served as president. In this respect, it was important for Hamilton not only to have black authors writing for the magazine but to have an African American printer as well, especially one who had experience working with African American political and civic groups.

In a burgeoning world of African American newspapers, broadsides, and pamphlets, Hamilton intended the Anglo-African Magazine to be different with its attention to matters cultural as well political. In his early years, Hamilton worked in various capacities for newspapers such as the Colored American (1837-42), the Evangelist (1845-48), and the National Anti-Slavery Standard (1840-70), giving him valuable experience in the work of publishing periodicals. Still, the idea of an African American magazine was unprecedented. Later in the same year Hamilton followed with the Weekly Anglo-African, which was meant to serve as a companion to the magazine with shorter articles and news coverage. As Deborah Jackson notes, Hamilton's operating costs were quite extensive, and he underwrote his endeavors publishing the magazine and newspaper by working as a bookbinder. Jackson also notes that he supplemented his income with a sideline business selling books, offering a wide selection by both white and black authors. ${ }^{16}$

It seems that Hamilton sought to advertise his magazine in areas of the country that had discernible free black populations that already had a subscription base with local or regional black newspapers. Such was the case in Ohio, a veritable bastion of black activism. Only a month after the first issue of the Anglo-African Magazine appeared, Oberlin College's Student Monthly reviewed it in the "Literary Notices" section, praising its "excellent literary matter" and concluding with the hope that "it could be put in the possession of every negrophobia-monger in the land." ${ }^{17}$ Notwithstanding the format, the Anglo-African Magazine was seemingly comparable to other black periodicals that focused on the condition of African Americans. Perhaps the closest equivalent was Frederick Douglass' Paper, which featured editorials, essays, poetry, and excerpted fiction in its pages. However, while most newspapers are meant to be disposable, it is evident that Hamilton intended the Anglo-African Magazine to have a degree of permanence. At the end of 1859, all twelve issues of the first year were bound and made available in book form.

With its especially keen focus on the literary arts, Hamilton most likely conceived of his magazine as suitable for the libraries of the nation's small but growing free black middle class. Indeed, when he writes of the 
need for an independent voice in the "fourth estate," it seems that he is referring as much to black newspapers as he is to the white publishing industry. A magazine may have seemed an unnecessary extravagance, perhaps even a waste of precious resources, given the demographics of African Americans who could afford such a luxury at midcentury, but it is clear that Hamilton wanted his magazine to be the black equivalent to those white-edited magazines that were proliferating in the publishing centers of Boston, Philadelphia, and New York.

In a short story written for the inaugural volume of the Anglo-African Magazine, William J. Wilson describes a number of paintings that his protagonist Ethiop views related to the history of African American editorial practices. Among the paintings that Ethiop views is a portrait of the editor of the Anglo-African Magazine itself who is portrayed surrounded by "piles of all the journals edited by colored men from the commencement [of African American publishing] up till the present," including Freedom's Journal, Colored American, People's Press, North Star, and Frederick Douglass' Paper. ${ }^{18}$ Significantly, hovering in the background unbeknownst to Hamilton is Samuel Cornish, the former editor of Freedom's Journal, which ran from 1827 to 1829 . The story's painting approximates a claim articulated by James McCune Smith, notwithstanding his sardonic tone, that "next to the pulpit, and behind the chairs, no place has greater charms for colored Americans than a seat in the chair editorial." ${ }^{19}$ In describing Ethiop's encounter with the painting, Wilson deliberately links Freedom's Journal to the Anglo-African Magazine as part of the same continuum. This continuum is underscored, however, less by the political orientation, format, or even style of the periodical than by the fact that each was under the editorship of an African American. In the painting, Hamilton is depicted sitting with Freedom's Journal, "the first journal ever edited by, and devoted to the cause of the colored man in America, held in one hand and outspread before him, while the other, as though expressive of his resolve, is firmly clenched." ${ }^{20}$ In representing Cornish as the "First Editor" and Hamilton as the "Last Editor," Wilson essentially imagines them as a kind of alpha and omega of black publishing.

There would, of course, be numerous black editors to come after Hamilton, but Wilson's use of Ethiop's fascination with a periodical "edited by, and devoted to the cause of the colored man" prefigures larger questions about race and editorial practices in the antebellum United States. ${ }^{21}$ In the most immediate sense, Wilson intimates the difference between periodicals like William Lloyd Garrison's Liberator, which were devoted to 
the abolitionist cause foremost, and those more specifically concerned with the condition of both enslaved and free African Americans. In a different sense, Wilson uses the painting's description to implicitly ask whether black authors could hope their writings would remain more or less unadulterated by white editors. Would black authors be able to freely and fully express themselves in publications primarily intended for white readers? In a metacritical sense, the spectral presence of Cornish in The First and the Last Colored Editor painting foreshadows the ways in which editorial concerns themselves have been recessed within the field of African American literary studies. When such concerns do arise in discussions of African American literature before the Civil War, for example, it is almost always in the context of the relationship between black writers and white editors such as Garrison, Lydia Maria Child, and Harriet Beecher Stowe. ${ }^{22}$

One of the fundamental characteristics of the Anglo-African Magazine that distinguishes it in significant degrees from its black and white literary counterparts was its emphasis on the condition of free as well as enslaved blacks. While the magazine strongly championed the abolition of slavery-and indeed nearly all its writers were activists in one way or another-Hamilton was also interested in publishing material that was not expressly related to the peculiar institution. Hence the decision to publish pieces as seemingly disparate as sheet music and articles about astronomy. This distinction was as much latent as it was ideological and was one that Hamilton registered in terms of temporality-in addition to serving as an "exposé of the condition of blacks," by which he means their past and present, the magazine "will have the aim to uphold and encourage the now depressed hopes of thinking black men, in the United States," by which he means their future. ${ }^{23}$

Indeed, Wilson's short story "Afric-American Picture Gallery" allegorizes the very dilemmas that Hamilton confronted as a black editor attempting to negotiate the ostensible bourgeois protocols of magazine publishing and racial representation. At one point Ethiop engages in a tête-à-tête with a white patron to the gallery: "I was about to remark," he said, "that if your men had capacity they might write for our antislavery journals and other ably conducted magazines in the country, such as Harpers' or the Atlantic Monthly. It would be more creditable. You don't want a separate magazine and pen up your thoughts there." ${ }^{24}$ The fictional encounter between Ethiop and the white visitor illuminates 
a number of concerns about black periodicals and editorial practices. On the one hand, the patron's comments contain a subsumed critique of value, by which, had they any "capacity," black writers might write for "more creditable" journals. On the other hand, his comments are decidedly political: black writers should not want to publish their ideas in "separate" magazines. But Ethiop counters that having "colored men" in the position of editors allows for a wider range of perspectives to be circulated by providing forums where black writers could more freely express their ideas.

Wilson's sketches themselves are exactly the type of writing that might not readily find a place in periodicals edited by white Americans and are therefore an illustration of the need for expressly African American forums. In Wilson's "Afric-American Picture Gallery," for example, Ethiop encounters an old black man who has captured his former white slave master and now holds him captive chained in a cave. Later in February 1860, he would publish "What Shall We Do with the White People?," an essay that seems almost inconceivable in any of the white-edited periodicals of the day. The same might be said of Martin R. Delany's novel Blake; or, the Huts of America $(1859,1861-62)$, which was initially serialized in the Anglo-African Magazine. Delany's vivid tale of black insurrection in the American hemisphere would hardly be palatable to antebellum white reading audiences, let alone have gained the initial approval of most white editors. By comparison, one of the closest examples to the kind of visceral account of black physical resistance one finds in Delany occurs in Douglass's short story "The Heroic Slave" (1853). But there, Douglass refuses to graphically depict such acts of black insurrection-an absence that was due as much to Douglass's own politics as it was Julia Griffith's position as editor of the gift book Autographs for Freedom (1853).

By approaching the Anglo-African Magazine archaeologically, we can gain a better sense of the decisions that constituted the basis of Hamilton's editorial practices of putting a group of writers of seemingly disparate ideological and political positions into the same orbit. If the Anglo-African Magazine was receptive to openly black militant thought, it was also receptive to a number of different political positions. On the one hand, authors like James Theodore Holly and Delany offered work that insisted blacks should leave the United States. On the other hand, authors like J. W. C. Pennington and J. Holland Townsend offered essays that maintained African Americans needed to stake their claim in 
the United States. Hamilton himself seems to have sympathized more closely with the latter position, writing in the first issue of the magazine that U.S. blacks ought not to be tempted by the allure of founding "an empire in Yoruba."

While the magazine did feature pieces from a number of different authors, it was nonetheless sustained by multiple contributions from a handful of regular authors. It ran at least three poems by Frances Ellen Watkins Harper as well as early examples of her fiction writing in "Two Offers" and nonfiction in "Our Greatest Want." Along with the education reformer Townsend and the Presbyterian pastor Pennington, the writings of both the emigration proponent Holly and essayist Smith were featured extensively throughout the first year. The majority of fiction that was published in the magazine came from three sources, all of which appeared over several issues: installments of Delany's novel Blake; Wilson's short story "Afric-American Picture Gallery"; and Jane Rustic's series "Fancy Sketches."

The sheer number of submissions from a relatively small number of writers reveals their dedication to support Hamilton's vision, but it also intimates the precariousness of any African American endeavor-less from the editorial perspective than from a publishing one-to produce a magazine during this period. The country's most well-known black public figure, Douglass edited a monthly that ran from 1858 to 1863 , but it was essentially a compendium of selections from his Frederick Douglass' Paper and was principally intended as a companion for foreign distribution. More established magazines like Godey's Lady's Book, Atlantic Monthly, and Harper's (Bazaar, Weekly, and Monthly) all enjoyed larger pools of readers from which to draw subscribers, and, furthermore, many were owned by book publishers that used them as vehicles to promote their books and cultivate authors. One example, in this regard, would be Edgar Allan Poe's relationship with the Southern Literary Messenger. By contrast, without the financial wherewithal of major publishing houses, the writers for Hamilton's Anglo-African Magazine did not generally benefit from such cross-ventures.

Black periodicals had had a continuous, if sporadic, presence in the world of newspapers from the late 1820 s on, but more ambitious and elaborate publications like magazines were both expensive and complicated ventures. Hamilton himself acknowledged as much when he wrote that the very appearance of the Anglo-African Magazine was "almost unparalleled in American Magazine literature." The utter exceptionalism 
of a publication of this type was acknowledged by readers of the AngloAfrican Magazine itself. In the November 1859 issue, Hamilton published a note from an "unknown friend" of the magazine who wanted to see it in public libraries.

Believing that the publication of your invaluable magazine is doing more to do away with the wicked prejudice existing against the black man, and to elevate him socially and politically, than by any other effort being made; and feeling that great good would result from placing it within the reach of the masses, I will give ten dollars towards creating a fund for placing a copy in every public library in this country. ${ }^{25}$

Hamilton closed the column with a list of pledges amounting to $\$ 48.50$ from a group of donors including Benjamin Coates, William T. Mercer, and Gerrit Smith. At the close of the magazine's first year, however, Hamilton had to concede that he had "not yet been able to pay" his writers. ${ }^{26}$ He lessened this admission slightly by using the word yet, as he remained hopeful that the magazine would increase its remittance rates for the following year. His operation's costs were somewhat absorbed by the generosity of his writers, who essentially contributed their works on contingency. But his publishing costs were exacerbated by his inability to rely upon or anticipate a consistent revenue stream through subscriptions. Based on the last (incomplete) extant issue of the magazine, Hamilton had to give up the venture in March 1860. The Anglo-African Magazine survived in a different guise when Hamilton started the Weekly AngloAfrican newspaper the following year. Beyond this, he remained active in the industry at least until 1863 when he acted as one of the publishers of William Wells Brown's The Black Man: His Antecedents, His Genius, and His Achievements.

Re-edit: Delany, Watkins Harper, and Smith and Contemporary African American Studies

The Anglo-African Magazine did not reappear again until 1968 when it was reprinted as part of the series The American Negro: His History and Literature, published by Arno Press and the New York Times. Edited by William Loren Katz, the series would eventually total 141 books. Its many 
titles included William and Ellen Craft's A Hundred Miles and Running (1860), William J. Simmons's Men of Mark (1887), and Negro Caravan (1941), edited by Sterling A. Brown, Arthur P. Davis, and Ulysses G. Lee. As the reviewer in Commentary noted, "the recent explosion of interest in Negro history" has prompted publishers to reissue "virtually everything," adding that of the "several valuable series of reprints, the most ambitious, extensive and useful" was The American Negro: His History and Literature. ${ }^{27}$ It is important to emphasize that this "explosion of interest in Negro history" was one of the products of the Civil Rights movement and those activists-both within academia and outside of it-who were reassessing if not challenging the meanings and sources of an ostensibly uniform national history. The Arno Press/New York Times initiative is a reminder of how social movements can influence editorial and publishing practices.

The Anglo-African Magazine remains an important artifact for any discussion of the history of nineteenth-century African American editorial practices as a document unto itself but also because of its significance to the practice of late twentieth- and early twenty-first-century textual scholarship. No complete volume with all of the magazine's issues has been republished. The Arno/New York Times volume reprinted the entire first year of its run, but the last three known issues of the magazine from January through March 1860 remain incomplete and only available at archives such as the Special Collections Library at the University of Michigan. While the Anglo-African Magazine has not been edited per se with a comprehensive introduction, research annotations, and footnote documentation, the works of several authors from it have been edited; examining the modern reprint history of these authors promises to illuminate some of the dominant currents in African American studies over the last four decades.

It is appropriate that the author who contributed the most pieces to the Anglo-African Magazine, Martin R. Delany, would also most likely be responsible for inspiring the current ongoing editorial return to the magazine. While Katz did in fact furnish an introduction for the magazine in his capacity as general editor for The American Negro: His History and Literature, it was relatively brief, at just one page. In this respect, Katz more or less merely reprinted the Anglo-African Magazine. One of the most vociferous calls of the late 1960s/early 1970s interest in African American history was for the recovery of texts that documented, or were written by, black militants in the vein of David Walker, Denmark Vesey, 
Gabriel Prosser, Henry Highland Garnet, and Nat Turner. Although his novel was fiction, Delany's protagonist Blake was one such figure. When Floyd J. Miller began preparing the first book edition of Blake, he had to return again and again to the Anglo-African Magazine and the Weekly Anglo-African. In returning to these periodicals, Miller discovered that six chapters of the novel are missing. He also determined that many of the songs and poems voiced by characters in the novel were actually poems by Delany's friend and colleague James Monroe Whitfield. ${ }^{28}$

Miller's footnotes for Blake are not overly detailed but they laid the foundation for later, more extensive textual scholarship. This kind of scholarship has come in the form of literary criticism through such works as Eric J. Sundquist's To Wake the Nations (1993) and Robert S. Levine's Martin Delany, Frederick Douglass, and the Politics of Representative Identity (1997). But this kind of textual scholarship has also been more explicitly and directly manifested in works like Martin R. Delany: A Documentary Reader (2003), edited by Levine. If Miller's initial editing of Blake was prompted by a latent desire to locate a discernibly radical tradition within the history of black America, then Levine's investment in textual scholarship on Delany was prompted by a need to recontextualize the field of antebellum African American literary studies that, in canonizing Douglass, had occasionally obfuscated the rich and divergent political positions within midcentury black intellectual thought.

From another angle, the initial publication and subsequent reissue of Blake raises a set of questions about contemporary editorial practices and the problem of different versions. Patricia Okker has suggested it is necessary to consider the two serializations of Blake as separate texts. ${ }^{29}$ As is well-known by readers of the novel, the setting of the 1859 version follows Henry throughout the South and Southwest, detailing the escape of his friends to Canada; the action is thus localized in the context of North America. The 1861-62 version (which subsumes and identifies the 1859 version as part 1) follows the protagonist's transformation from Henry to "Blacus," as he travels from Cuba to Africa and back to Cuba. The scope of the 1861-62 version thus opens into the greater hemisphere of the Americas as well as the circum-Atlantic. Okker has underscored the historical differences between the two serializations of Blake as one of the important distinctions that distinguish them as separate texts.

However, another way to consider the problem of Blake as it relates to editorial practices is to contextualize Delany with midcentury contemporaries like Herman Melville and Walt Whitman. The British edition 
of Melville's classic novel (then entitled The Whale) mistakenly failed to include the epilogue and consequently refashioned the entire work as if it had been offered from the perspective of a dead Ishmael rather than from one who had actually survived the destruction of the Pequod. The original U.S. edition published a month later is the version upon which most twentieth- and twentieth-first-century reprints are based. Because the elision of the epilogue damages the narratological underpinnings of the novel by essentially changing the story line, the British edition is rarely consulted. Delany's Blake is similarly analogous. Its serial republication in the Weekly Anglo-African maintained the same narrative voice and theme (with Henry/Blacus plotting slave insurrection), but the story line of the second is substantially extended. Can the 1861-62 edition really constitute a separate text insofar as the 1859 edition was effectively interrupted? By Hamilton's own admission, he intended to publish some eighty chapters of Delany's novel; thus, in modern reprints, the $1862-62$ iteration is commonly understood as the authoritative version. From a different position, one might consider the print history of Whitman's Leaves of Grass from its original publication in 1855 to the so-called death-bed one of 1891-92. How scholars assess the differences in the constitutional makeup of Leaves of Grass bears directly on the distinction between "edition" and "issue." Whitman himself considered the last edition to be the most complete one; are readers who take up the 1855 edition, then, only partly reading Whitman? Whereas Whitman's volume grew and grew to comprise nearly 400 poems, readers who only take up the 1859 version of Blake (as many readers of Whitman only read the 1855 edition) would necessarily encounter a truncated novel, in both the textual body of the novel and its plot as well. But to take up the 1859 version of Blake alone is also concomitantly to take up the Anglo-African Magazine because no book version of it exists as such, and any engagement with the first iteration of Blake would, as Katy Chiles notes, also necessitate a simultaneous engagement with the particular social history of mid-nineteenth century print and periodical culture. ${ }^{30}$

The print peregrinations of Blake make it illustrative of the kind of examination that John L. Bryant calls "fluid textual" analysis (whereby a given work is studied for its authorial, editorial, and cultural alterations) as well as the kind of editorial practices sponsored by the Collegium for African American Research that sponsors the Clotel Project (which presents the four versions of Brown's novel in an innovative electronic scholarly edition). ${ }^{31}$ If Bryant's call for fluid textual analyses is informed 
equally by history-of-the-book criticism as well as New Historicism, the Clotel Project evinces the developments in editorial practices when African American literary scholarship self-consciously shifts to looking for themes and settings beyond the precincts of the United States alone.

While the impulses emanating from the broader Civil Rights movement compelled the publishing industry during the late 1960s/early 1970 s to reprint works like Blake that were out of print, black feminist scholars were also pointing out the need to unearth the specific contribution of women to the African American literary tradition. As Henry Louis Gates Jr. notes in his introduction to the Schomburg Library of Nineteenth-Century Black Women Writers, most scholars of African American studies had not read this literature because it was accessible only in archives of rare books.

For reasons unclear to me even today [in 1988], few of these marvelous renderings of the Afro-American woman's consciousness were reprinted in the late 1960 s and early 1970s, when so many other texts of the Afro-American literary tradition were resurrected from the dark and silent graveyard of the out-of-print and were reissued in facsimile editions aimed at the hungry readership for canonical texts in the nascent field of black studies. ${ }^{32}$

Writing over the course of the second half of the nineteenth century in nearly every genre, France Ellen Watkins Harper was one of the central figures that editors sought to recover. Perhaps still known more for her novel Iola Leroy (1892) than for her poetry or essays, Watkins Harper spent the early part of her writing career primarily as a poet, publishing in periodicals like Frederick Douglass' Paper, the Liberator, and the Anglo-African Magazine. Among the women published in Hamilton's magazine-Mary Ann Shadd Cary, Grace Mapps, Sarah M. Douglass, and Jane RusticWatkins Harper was by far the most prolific contributor.

The two collections of Harper's work make different use of the AngloAfrican Magazine and illuminate different currents in African American textual scholarship. Edited by Maryemma Graham, the Complete Poems of Frances E. W. Harper is a part of the Schomburg Library of Nineteenth-Century Black Women Writers series that was published by Oxford University Press in 1988. In her introduction to the Schomburg edition, Graham reveals the difficulties of editing a writer like Watkins Harper. Commenting that Watkins Harper was a frequent contributor to 
nearly all of the major black periodicals of the day, Graham also notes that the bulk of her occasional poetry, letters, and speeches remain uncollected. The Schomburg edition of Watkins Harper's complete poetry, she adds, "comes at an appropriate time in the reassessment of her canon. Its publication alone more than justifies the need to restore Harper to her proper social and literary context in the mid-nineteenth century and to see her development of the genre in which she wrote." ${ }^{33}$ In the wake of work by historians who have explored the meanings of racial uplift ideologies and literary critics who have focused on the cultural politics of racial passing, Watkins Harper's Iola Leroy became an important text for scholars working in African American studies at least as early as the late 198 os. $^{34}$ Less attention was paid to her antebellum poetry, in part, it must be said, because the 1850 os is so heavily identified with Walt Whitman and Emily Dickinson. Restoring Watkins Harper to "her proper social and literary context" would not only necessitate a thematic focus on the mulatta trope, for example, from Eliza Harris to Iola Leroy, but situate Watkins Harper in relation to Whitman, Dickinson, and other midcentury poets.

By circumscribing her volume to Watkins Harper's poetry, one of the results of Graham's edition is that it traces the contours of a specific genre over the course of time rather than presenting multiple genres of her work bound together as sections underneath a distinct conceptual rubric or discrete historical period. This latter approach is closer to the one that Frances Smith Foster took to edit her anthology A Brighter Coming Day. Because of the wider scope of this project, Foster's book includes Watkins Harper's essay "Our Greatest Want" and two pieces of fiction, "The Two Offers" and "The Triumph of Freedom-A Dream," both originally published in the Anglo-African Magazine. Divided into four major parts, A Brighter Coming Day has the advantage of allowing its reader to correlate ideas across different forms of writing to limn the governing preoccupations of her thought. The material in Foster's anthology also is closer in presentation to nineteenth-century publications in which Watkins Harper's work appeared, featuring, as they did, multiple genres.

While both Graham's and Foster's editions are suitable references for research, Foster's edition has more of a feel for public and not just academic consumption. It was published two years after the Schomburg edition in 1990 by the Feminist Press with support from the City University of New York, after a slew of black feminist scholars, including Hazel Carby, Deborah McDowell, and Mary Helen Washington, among oth- 
ers, had gone searching for their mothers' gardens, to borrow a phrase from Alice Walker. According to its own self-description, the Feminist Press began in 1970 by 'rescuing 'lost' works by writers such as Zora Neale Hurston and Charlotte Gilman." ${ }^{35}$ Ultimately, however, what the Graham and Foster publications reveal is the pressing need for continued archaeological work on Watkins Harper that will increasingly move toward recovering the archive of her entire corpus.

If the initiatives to recover the work of Delany and Watkins Harper were prompted by the radical black and feminist social movements of the late 1960 s and early 1970s, the case of James McCune Smith intimates the delicate relationship between the academic work of African American editorial practices and the commercial aspects of the publishing industry that might print such scholarship. Of the three major contributors to Hamilton's Anglo-African Magazine, Smith has until recently remained the most neglected. A commanding intellectual in his own right, Smith is most known for writing the introduction to Douglass's second autobiographical outing, My Bondage and My Freedom (1855). Smith's introduction was an important moment in the history of African American textual scholarship itself. Rather than repeat the formula of having a white authenticator furnish prefatory comments or claim editorial authority over the text, Douglass chose to have Smith's voice open My Bondage and My Freedom. ${ }^{36}$

As scholars, literary critics in particular, began to move away from the primacy of the earlier Narrative of the Life of Frederick Douglass (1845) to consider the larger panoply of his autobiographical writing, Smith increasingly emerged as a significant figure in relation not only to Douglass's personal history but to the social history of nineteenthcentury African American political thought. Perhaps the scholar most identified with the recent recovery of Smith is John Stauffer, who works at the intersection of history and literary criticism. In The Black Hearts of Men (2001), Stauffer offered biographical sketches of John Brown, Douglass, Smith, and Gerrit Smith to illuminate a radical interracial tradition of the abolitionist movement. In conducting the research for his study, Stauffer recovered a number of primary documents related to Smith, some of which became the basis for his edited volume on him.

The very possibility of Stauffer's edited volume The Works of James McCune Smith: Black Intellectual and Abolitionist seems as much a result of his own research for The Black Hearts of Men as of the current "archival turn" in African American literary studies. This turn includes reassessing 
canonical authors for their lesser-studied works and unearthing works by little-known writers outside of the Northeast corridor displayed in critical analyses such as Eric Gardner's Unexpected Places (2009). The Works of James McCune Smith, like the other titles in the Oxford Collected Black Writing series, gathers the occasional essays of nineteenth-century public intellectuals. Much of this writing was published in black periodicals, some of which were preserved by archivists to transfer them to microfilm beginning in the 1930s. In his introduction to his Smith volume, Stauffer laments that Smith has remained in relative obscurity and notes three particular issues that may account for the delay in resurrecting him from the "waves of obscurity": Smith published no book during his lifetime; his genre of choice was the essay; and his papers were never collected. ${ }^{37}$ But in the foreword to the series by Henry Louis Gates Jr., it never becomes evident why the Oxford Collected Black Writing series emerges with its first trio of publications in 2006. That is, the series does not have an obvious theme that patently undergirds its titles nor an ostensible social movement prompting its production. It is also noteworthy, however, that of the projects that Gates recalls would form the basis for a "textual legacy" of African American memory-including the Douglass Papers, the Norton Anthology of African American Literature, and Africana: The Encyclopedia of the African and African American Experience-the Oxford Collected Black Writings series was among the last to reach a print platform. ${ }^{38}$ Without extrapolating too much from the particular trajectory of Gates's own editorial initiatives, this series might be said to be a return to the archive for the sake of returning to the archive. In a larger sense, this archival turn also signals a certain state in the institutionalization of African American studies that no longer requires an immediate political concern or social movement to authorize its lines of critical inquiry.

\section{The (W)hole of It}

If, as I have tried to show, contemporary editorial engagements with nineteenth-century writing have primarily been author-centered, what might a focus on the periodical mean to how the arc of African American literary criticism is conceptualized? The three writers discussed here have all been reintroduced to modern readers as illustrations of certain kinds of discourse: Delany and radical politics; Watkins Harper and feminism; and Smith as a key example of what Stauffer calls interracial 
friendship. My own conclusion is not that contextualizing these writers in any particular discourse is incorrect but rather that it is more advantageous to read these authors together, to be forced to engage the multitudinous and sometimes contradictory ideas of these writers at specific moments. In this sense, I echo Frances Smith Foster's recent call that we recognize the heterogeneity of early African American periodicals, which constituted, in her words, "a smorgasbord of the practical and pedantic, scholarly and serviceable, informative and diversionary." ${ }^{39}$ Given its importance to mid-nineteenth century African American thought, the Anglo-African is a precursor to later periodicals like the 1924 special issue of Survey Graphic and the single 1926 issue of Fire!! My implicit call, then, for the Anglo-African to be edited is also an implicit call for scholars to think synchronically as well as diachronically-a critical maneuver that the archival turn opens as both a possibility and a promise.

Notes

1. I am, of course, riffing on Junot Díaz's novel The Brief Wondrous Life of Oscar Wao (2008), which itself constitutes a complex textual artifact that marshals a fascinating array of material.

2. James Monroe Whitfield, "Prospectus of the Afric-American Quarterly," Provincial Freeman and Weekly Advertiser, December 6, 1856, 196.

3. Ibid., 194 .

4. Ibid., 195.

5. Ibid., 197.

6. See The Black Press: New Literary and Historical Essays, ed. Todd Vogel (New Brunswick: Rutgers University Press, 2001), and Elizabeth McHenry, Forgotten Readers: Recovering the Lost History of African American Literary Societies (Durham: Duke University Press, 2002).

7. Bryan, "Negro Journalism before Emancipation," 19.

8. Penn, The Afro-American Press and Its Editors, 63-65.

9. Freedom's Journal, March 16, 1827.

10. Weekly Advocate, January $7,1837$.

11. Hamilton, “Apology (Introductory.)," 1.

12. Hamilton, "Prospectus of the Anglo-African Magazine," n.p.

13. For a brief biographical sketch of Zuille, see Brown, Rising Son, 473-74; for more specific details on his political activity, see Wilder, In the Company of Black Men, 268.

14. Brown, Rising Son, 473. Zuille remained active in publishing after the Civil War, printing at least one work, Oration, by James Crosby, a Colored Man, in 1867. His own position as a printer puts into high relief a set of questions about African American textual production in the nineteenth-century United States, especially in the antebellum period: What was the relationship between black writers and white publishers, particularly in the Northeast corridor from Philadelphia to Boston? What happened 
if a black editor could not find a printer to publish his or her material? Were there printers who were ambivalent or even antagonistic to the ideas of a black publisher and refused to accept a printing job? Such questions return us to the materiality of textual production, reminding us that printers themselves were important cogs in the machinery of political discourse: black publishers might have had a steady roster of writers and a ready audience to consume their work, but without a printer to put these words to some kind of media (whether newspaper, pamphlet, broadside, magazine, or other) the circulation of their ideas or that of their writers would have much different, if not narrower, circulatory patterns.

15. As Frank Moss wrote about the area in his history of New York City as a metropolis, "The square will ever be famous as the place where The Great American Newspaper has had its development. [Horace] Greeley, [Henry Jarvis] Raymond, [Charles Anderson] Dana, [George] Jones, and many others, hardly less famous, have done their life work here, and have enriched the nation and world by it" (The American Metropolis, 214).

16. Jackson, "Thomas Hamilton."

17. Oberlin Students' Monthly, 38. It is possible that the notice was furnished by John Langston Mercer, who was a graduate of the college and listed in the table of contents as a contributor.

18. Wilson, "Afric-American Picture Gallery-First Paper," 53.

19. McCune Smith, "The Editor," 215.

20. Wilson, "Afric-American Picture Gallery-First Paper," 53.

21. Ibid.

22. See, for example, Garrison's introduction to Frederick Douglass's Narrative of the Life of Frederick Douglass (1845); Child's introduction to Harriet Jacobs's Incidents in the Life of a Slave Girl (1861); and Stowe's essay "The Libyan Sibyl” (1863), subsequently included in the 1875 and 1884 editions of Sojourner Truth's Narrative.

23. Hamilton, "Apology (Introductory.)," 3.

24. Wilson, "Afric-American Picture Gallery-Second Paper," 89.

25. Anon., "The Anglo-African Magazine for All Our Public Libraries-Who Will Aid?," 368 .

26. Hamilton, “The Anglo-African Magazine for 1860," 400.

27. Donald, "Black History," 85.

28. Miller, "Introduction," xi.

29. Okker, Social Stories, 101. See also Cole, "Theresa and Blake," 163-64.

30. Chiles, "Within and without Raced Nations," 327.

31. See John Bryant, The Fluid Text: A Theory of Revision and Editing for Book and Screen (Ann Arbor: University of Michigan Press, 2002).

32. Gates, "Foreword," xix.

33. Graham, "Introduction," xxxvi.

34. On racial uplift ideology, see Kevin Gaines, Uplifting the Race: Black Leadership, Politics, and Culture in the Twentieth Century (Chapel Hill: University of North Carolina Press, 1996). Among the extensive criticism on Iola Leroy and passing, see Hazel V. Carby, Reconstructing Womanhood: The Emergence of the Black Woman Novelist (New York: Oxford University Press, 1987), 71-94, and Michelle Birnbaum, Race, Work, and Desire in American Literature, 1860-1930 (New York: Cambridge University Press, 2003), 58-75. 
35. "About FP." Feminist Press. 2011. Northwestern University. 9 December 2011. http://www.feministpress.org/about-fp.

36. In Robert S. Stepto's language, these prefatory comments functioned as "authenticating documents" that legitimated the veracity of the author's claims. See Stepto, From Behind the Veil, 6-7.

37. Stauffer, "Introduction," xvi.

38. Gates, "Foreword," viii.

39. Foster, "Genealogies of Our Concerns," 378.

\section{Works Cited}

Anon. "The Anglo-African Magazine for All Our Public Libraries-Who Will Aid?" In Anglo-African Magazine, ed. William Loren Katz, 368. New York: Arno Press and New York Times, 1968.

Brown, William Wells. The Rising Son: or, The Antecedents and Advancement of the Colored Race. Boston: A. G. Brown, 1873.

Bryan, Carter R. "Negro Journalism Before Emancipation," Journalism Monographs 12 (September 1969): 1-33.

Chiles, Katy. "Within and without Raced Nations: Intratextuality, Martin Delany, and Blake; or the Huts of America." American Literature 80, no. 2 (2008): 323-52.

Cole, Jean Lee. "Theresa and Blake: Mobility and Resistance in Antebellum African American Serialized Fiction." Callaloo 34, no. 1 (2011): 158-75.

Donald, David. "Black History." Commentary 49, no. 4 (April 1970): 85-88.

Foster, Frances Smith. "Genealogies of Our Concerns, Early (African) American Print Culture, and Transcending Tough Times." American Literary History 22, no. 2 (2010): 368-80.

Freedom's Journal. Editorial statement. March 16, 1827.

Gates, Henry Louis, Jr. "Foreword." In The Works of James McCune Smith, ed. John Stauffer, vi-xii. New York: Oxford University Press, 2006.

Graham, Maryemma. "Introduction." In Complete Poems of Frances E.W. Harper, xxxiii-lviii. New York: Oxford University Press, 1988.

Hamilton, Thomas. “Apology (Introductory.).” In The Anglo-African Magazine (1859), ed. William Loren Katz, 1-4. New York: Arno Press and New York Times, 1968.

Hamilton, Thomas. "Prospectus of the Anglo-African Magazine.” New York: J. J. Zuille, 1859. N.p.

Jackson, Debra. “Thomas Hamilton.” In African American National Biography, ed. Henry Louis Gates Jr. and Evelyn Brooks Higginbotham. 2008. Northwestern University. December 9, 2011. http://www.dev.anb.org/article/opr/t0001/e2821.

McCune Smith, James. “The Editor." In The Works of James McCune Smith, ed. John Stauffer, 211-16. New York: Oxford University Press, 2006.

Miller, Floyd J. "Introduction." In Blake: or, The Huts of America, a Novel, ed. Floyd J. Miller, xi-xxxix. Boston: Beacon Press, 1970.

Moss, Frank. The American Metropolis: From Knickerbocker Days to the Present Time; New York City Life in All Its Various Phases. New York: Peter Fenelon Collier, Publisher, 1897. 
Oberlin Students' Monthly: A Religious, Political, and Literary Magazine 1, no. 4 (February 1859$)$.

Okker, Patricia. Social Stories: The Magazine Novel in Nineteenth-Century America. Charlottesville: University of Virginia Press, 2003.

Penn, I. Garland. The Afro-American Press and Its Editors. Springfield, MA: Wiley, 1891.

Stauffer, John. "Introduction." In The Works of James McCune Smith, ed. John Stauffer, xiii-xl. New York: Oxford University Press, 2006.

Stepto, Robert S. From Behind the Veil: A Study of Afro-American Narrative. Urbana: University of Illinois Press, 1979.

Weekly Advocate. January 7, 1837.

Whitfield, James M. "Prospectus of the Afric-American Quarterly." In The Works of James M. Whitfield: America and Other Writings by a Nineteenth-Century African America Poet, ed. Robert S. Levine and Ivy G. Wilson, 194-98. Chapel Hill: University of North Carolina Press, 2011.

Wilson, William J. "Afric-American Picture Gallery-First Paper." In Anglo-African Magazine, ed. William Loren Katz, 52-55. New York: Arno Press and New York Times, 1968.

Wilson, William J. “Afric-American Picture Gallery-Second Paper." In Anglo-African Magazine, ed. William Loren Katz, 87-90. New York: Arno Press and New York Times, 1968.

Wilson, William J. “The Anglo-African Magazine for 1860.” In Anglo-African Magazine, ed. William Loren Katz, 400. New York: Arno Press and New York Times, 1968. 


\title{
George Hutchinson
}

\section{REPRESENTING AFRICAN AMERICAN LITERATURE}

\author{
Or, Tradition against the Individual Talent
}

Literary historiography, criticism, and editorial work have done their parts in defining what Darby English has recently termed "black representational space," an institutional enclosure that has developed out of the history of racist segregation, on the one hand, and strategies of recruiting art by African Americans to the struggle against racism or for racial uplift, on the other. ${ }^{1}$ One finds similar dynamics, it seems, wherever a minoritized group occupies a majoritarian literary field. Through myriad processes, the cultural productions of "minority" artists become identified with what distinguishes them from the so-called mainstream, their ability to represent the minority in its distinctiveness, while other features of the texts are subordinated or even transformed in order to bring them into alignment with a presumed tradition. This process, in turn, willy-nilly aids the reproduction of the majority/minority distinction and thus sustains the form and volume of the mainstream, though it is repeatedly troubled by contradictions deriving from the fact that cultural invention derives from liminality (but, I want to stress, not necessarily racial liminality) and from the fact that the very notion of what constitutes a work of "literature" or "art" is always produced in relation to a discourse that traverses social boundaries even as different social groups struggle for position in defining what constitutes "art" or "literature," with unequal access to the resources through which such terms are defined. Over and over, the most significant cultural developments emerge at the boundary-often to be subsequently acculturated to the system of difference that sustains the prior order of things. In this essay, I will address two different ways in which this occurs in the representation of African American writing that was produced during the era when a modern black literary field initially took shape as such: first, in the processes of anthologizing, with Countee Cullen as a case study; second, in 
the design of the paratextual elements and bibliographic codes that help shape a text's reception, using Cullen again and then focusing on the case of Nella Larsen's Passing.

We are accustomed to thinking that racism in the American publishing industry of the 1920 s constrained black literary production by forcing black authors to write in ways that conformed to white audience expectations. Moreover, relationships between white patrons and black authors prevented the latter from expressing themselves freely-a dynamic that, to be sure, affects all patron/author relations but has greater repercussions when poised on the color line. Above all, white publishers' and patrons' insistence that black authors represent the race as "primitive and exotic," according to common understandings, severely contained or distorted New Negro self-expression. Thus present-day republication of black-authored texts rescues those texts from the confining structures in which they necessarily emerged and, by placing them within the frame of a robust African American literary tradition they themselves helped create, allows a more accurate understanding of the cultural work they performed. Undoubtedly, white publishers of the period were racist and invested in the distinctiveness of "Negro literature," and they identified that distinctiveness with respect to circulating notions of what was "Negro" to majority-white audiences; ${ }^{2}$ however, the hope that present-day constructions of African American literary traditions can help rescue texts of the 1920 from distorting conditions can actually reproduce and even magnify the institutional boundaries that developed at that time, submerging or overwriting important features of the texts and of their engagement with history. When biographical evidence conflicts with current theory, one might wonder if current reconstructions of the intertextual relations that produce "black literature" have been overdetermined by unstated, and flawed, biographical and historical hypotheses. When the fallacies of such hypotheses are exposed, we might catch a glimpse of the racialized horizons of expectation in which contemporary representations of black-authored writing and even textual scholarship operate.

\section{Countee Cullen}

Between 1924 and 1930, Countee Cullen's poems appeared regularly in journals that dominated the mainstream of American literary 
publishing-magazines like Harper's, Poetry, Century, American Mercury, and the New York Herald Tribune Books-as well as more specialized literary magazines and such African American magazines as Opportunity and The Crisis. Gerald Early has argued that Cullen's work defined the Harlem Renaissance more than that of any other writer, and that in 1925 he was the most celebrated black poet in the United States. As late as 1951, a Harlem branch of the New York Public Library was named for him, the sort of honor that at the time had been accorded no other black author of his generation. ${ }^{3}$

It is common knowledge that Cullen's reputation suffered after the 1920 from the fact that he wrote in late romantic tones and very traditional forms at a time when high modernism was coming to dominate the field of poetry. Perhaps partly for this reason, along with the rising influence of academic criticism and college texts, Cullen's reputation faded to the point that he came to be known almost exclusively for his "racial" verse-which used the same forms as his other verse but was distinguished by its subject matter. Implicitly, his poetry on nonracial subjects was too much like late romantic "white" poetry to be of interest. Eventually, what were perceived as tensions between his racial subject matter and the forms he used helped to partly resuscitate his reputation. Moreover, his poetry on racial subjects could become part of a theory of the subversive relation of black to white texts, or "mastery of form" in Houston A. Baker Jr's influential formulation. His poems have thus been folded back into the realm of black representational space.

Cullen knew all too well the pressures in this direction, and resisted them. He wanted Harper as his publisher precisely because it was associated with what at the time were considered the most canonical British and American authors. In the 1920s, most of those who admired Cullen did so because of his attachment to traditional forms as well as what they took to be the quasipagan passion and "soul" with which he invested those forms. They liked his poems on racial subjects, but they also liked his poems having no racial reference. The traditionalism and range of subject matter, as well as what was considered his pagan-spiritual temperament (partly attributed to his race), were central to his poetic identity.

Comparing the representation of Cullen's poetry in the 1920s with that since the 196os, one finds an extreme narrowing of subject matter. Whether looking at the original appearance of clusters of his poems in periodicals, or in anthologies of the 1920 s edited by both blacks and whites, or Cullen's own books, one is struck by the different sense of 
where Cullen "fits" in the literary field. ${ }^{4}$ We are used to thinking that editors and publishers of the New Negro era had a stifling effect on black talent and narrow views about how and on what black writers should write - and there is plenty of truth to this thinking - but in Cullen's case they were more catholic than their successors.

His first book, Color, is by far the most racially focused of all Cullen's poetry collections. Put together much under the influence of Alain Locke's encouragement of "paganism" and drawing on the "race endowment," even this volume, however, is composed mostly of poems with no racial reference. A long section of Color entitled "Epitaphs" contains twenty-nine short poems for a wide variety of character types, acquaintances, and literary heroes. When these poems first appeared in magazines, they most often came out in clusters under the "Epitaphs" heading, as they do in Color. Today, they are usually presented as freestanding poems, and the only ones reproduced are those few explicitly addressed to African Americans (e.g., Cullen's grandmother, Paul Laurence Dunbar) or the one epitaph for the upper-class racist white woman "type" memorialized in "For a Lady I Know." You will not find "For Joseph Conrad," or "For Hazel Hall, American Poet," for example-nor "For an Anarchist," "For an Atheist," "For a Skeptic," "For a Magician," "For an Evolutionist and his Opponent," "For a Poet," "For a Cynic," and so on. The dust jacket of Color stressed the fact that much of Cullen's poetry was not about his race, which was considered, inaccurately, unusual for a black poet.

One of the first anthologists to use Cullen's poetry was Alain Locke, who chose exclusively "racial" poetry to advance his own interpretation (or projection) of an emergent New Negro identity. Locke conferred with Cullen about what is perhaps his most well-known poem, "Heritage," as it took shape, and convinced Cullen to reserve it for Locke's use in the famous special issue of the magazine Survey Graphic entitled "Harlem: Mecca of the New Negro" (1924). In that publication he coupled it with photographs of African masks, and the poem itself was drastically different from the version used by Cullen himself in his book Color (1925) and his anthology Caroling Dusk (1927), as well as his self-selected poetry volume On These I Stand (1947). So far we have no direct evidence that Locke altered the poem himself in a major way and that Cullen subsequently published an "earlier" version that he preferred. In fact, it is more likely that Cullen revised the poem after its appearance in Survey Graphic but before the republication of that version in The New Negro, 
for Color came out in the same year as The New Negro and had the more "decadent" and "queer" version.

A typescript copy of a never-published early version of "Heritage," closer to the one used by Locke than by "later" published versions, can be found in the Alain Locke Papers. ${ }^{5}$ It provides invaluable perspective on the poem's development and glosses on ambiguous lines in the later versions. The typescript, probably by Cullen himself, has handwritten revisions (in handwriting resembling Locke's) that were incorporated into the version published by Locke, and yet differs from that published version as well. I would surmise that it dates to spring 1923, when Cullen and Locke were corresponding about the poem, and that Cullen and Locke together made further changes prior to its first publication. ${ }^{6}$ This seems to be a case in which an elder mentor/critic/editor influenced the development of a poem that the poet later independently revised in a major way. A significantly different, typeset version of the poem along with a few of Cullen's other poems can also be found in the same folder of the Locke papers.

In any case, the version in which Locke collaborated lacks the decadent motifs of the one Cullen consistently chose to publish, and it foregrounds pagan/primitivist qualities in conformity with Locke's view of African American tradition. ${ }^{7}$ This version also lacked Cullen's dedication of the poem to his intimate gay friend, Harold Jackman. Similarly, in The New Negro, Locke positioned "Heritage" to introduce his own essay "The Legacy of the Ancestral Arts," as if to gloss his own position on the connection between African classicism and the Negro Renaissance. ${ }^{8}$

It is well-known that Locke was cavalier in editing other contributions to Survey Graphic and the subsequent anthology, The New Negro: An Interpretation. More revealingly, he published "his" version of Cullen's poem yet a third time, in the pamphlet Four Negro Poets (1927), a collection prefaced by an argument about the racial "representativeness" of the poems and the emphasis of younger Negro poets on the "racial heritage." Jean Toomer, one of the poets, must have been infuriated at his inclusion in the pamphlet; he no longer wished to be identified as a Negro and had never regarded his book Cane as an example of Negro literature, although he was happy that it had inspired many Negro writers. It may well be that Locke used "his" version of "Heritage" without Cullen's permission, as well, for by now Cullen's version from Color had been out for two years and remained his choice for publication. In his own review of Four Ne- 
gro Poets, Cullen explicitly rejected Locke's argument concerning a racial heritage and subsequently distanced himself from Locke both personally and intellectually. ${ }^{9}$ Cullen's additions and alterations may be related to the reasons for which he distanced himself from Locke by 1927. Yet Locke may well have altered the poem on his own, as well; we know for certain that Locke changed the title of McKay's poem "The White House" without even informing McKay. McKay strongly objected when he found out, but Locke ignored his protests and went on to once again publish, without permission, "The White House" under the title "White Houses" in The New Negro. ${ }^{10}$ Locke also published work by Jean Toomer in The New Negro without permission from the author. Toomer had sent him an essay giving his thoughts on the Negro literary awakening from the point of view of someone who did not consider himself a part of it. But instead of using the essay, Locke used portions of Cane that would imply Toomer's position as a representative "New Negro," infuriating Toomer. ${ }^{11}$ Thus, relations between black authors and black editors are not necessarily less vexed by racial expectations than those between black authors and white editors. (This point does not change the much more important structural influence of white hegemony in the publishing industry, of course.) In none of his own publications did Cullen use Locke's version of his poem. When Cullen came out with his own anthology of contemporary verse by African Americans (he refused to acknowledge the possibility of "Negro poetry"), he pointedly contested Locke's positions: "As heretical as it may sound, there is the probability that Negro poets, dependent as they are on the English language, may have more to gain from the rich background of English and American poetry than from any nebulous atavistic yearnings toward an African inheritance." 12

In the same year that Color was published, Cullen began pursuing a master's degree at Harvard (1925-26) and came under the influence of William Stanley Braithwaite, a black man of West Indian background who had once been literary editor of The Crisis and was awarded the NAACP's coveted Spingarn medal in 1918 for his contributions to the "race" as a poet and anthologist. Braithwaite's poems rarely featured specifically racial subject matter, and his favorite poets tended to write late romantic verse of an Edwardian cast, rather like the verse that Cullen admired. Cullen dedicated his anthology Caroling Dusk to Braithwaite as the "real begetter of this anthology," and it remains notable for the extraordinary range of poetic styles and themes it includes, with headnotes written by the poets themselves.

According to Cullen, “This country's Negro writers may here and 
there turn some singular facet toward the literary sun, but in the main, since theirs is also the heritage of the English language, their work will not present any serious aberration from the poetic tendencies of their times." ${ }^{13}$ Caroling Dusk is the most representative sampling I have seen of poetry by black authors from that era. In this respect, it can be seen as an extension of William Stanley Braithwaite's work as an anthologist who published a vast range of poets (of all backgrounds), and who did not consider race a significant factor in the production of poetry, even though he very much wanted to help poets who were black succeed. ${ }^{14}$ Also like Cullen, Braithwaite did not want to be considered a "Negro poet," thinking it would distort the reception of his work.

After Color, Cullen began feeling that black and white critics both (most notably Alain Locke) were trying to force him into a poetic role he found constricting. His next volume of poetry, Copper Sun of 1927, moved away from the kind of paganism and racialism Locke valued. Copper Sun included illustrations (and dust-jacket art) by the artist Charles Cullen, featuring mostly nude or seminude white female and male and occasionally black male figures in dramatic poses, in a decadent Art Nouveau style apparently inspired by Aubrey Beardsley. The name of the artist is fortuitous; Charles bore no relation to Countee. He was a struggling white artist whose greatest claim to fame was his work on Cullen's books. The poet enjoyed the collaboration and became Charles's champion with editors at Harper; they corresponded and continued to work together on Countee's later books. Indeed, a new version of Color came out in 1928, illustrated by often intensely homoerotic illustrations by Charles. (New printings of this version came out until at least 1931.) As James Kelley has pointed out, "the drawings in Color present nude men, white as well as black, sometimes muscled but more often androgynous, alongside burning candles and dripping lilies that seem to draw their inspiration from art nouveau." ${ }^{15}$ These qualities of Cullen's most racially focused book somewhat destabilized its "representative" work for the race and the traditional correlation drawn between normative heterosexuality, masculine identity, and racial uplift-all aspects of Cullen's popular persona. Also, very unusually for canonical African American literature, they gesture toward erotic pleasure. Considering the deep taboos surrounding, particularly, black male and gay sexuality, the illustrated version of Color represents an audacious response to New Negro configurations of representative black masculinity, all the more significant because Countee Cullen was considered one of the most "representative" of New Negroes, a credit to his race. ${ }^{16}$ 
Cullen's identification with the poetic stance of Edna St. Vincent Millay, on whom he wrote his master's thesis at Harvard, emerges only when one reads a wider variety of his work than that usually anthologized today, and particularly when one reads his books in the original. In the 1920 both poets frequently used the ballad stanza, whether for short, epigrammatic poems or for extended ballads as such-notably Cullen's "The Ballad of the Brown Girl" (which was not "about" a black woman, although Cullen intended that it could be so interpreted) or Millay's "The Ballad of the Harp-weaver." "The Ballad of the Brown Girl," incidentally, was Cullen's only poem published independently as a lavishly illustrated (by Charles Cullen) deluxe book, dedicated to Witter Bynner. It was a "retelling" of an ancient ballad, according to Cullen's subtitle. Another favorite form of both poets, of course, was the sonnet, to which they introduced unconventional tone and subject matter. Copper Sun's dedication "To the Not Impossible Her" deliberately plays on Millay's poem "To the Not Impossible Him," which, given her widely known bisexual orientation, would be read by many as an ironic allusion to her sexual attraction to women: "He" is not impossible, but he must accept "her" need to roam. Cullen's title references his brief marriage to Yolande $\mathrm{Du}$ Bois after one of the New Negro era's most iconic weddings. The tension between Cullen's "representative" New Negro status and the passions subtending his poetry rarely came so near the surface and are more easily legible when one recognizes his affiliation with Millay or reads his poems alongside the Charles Cullen artwork. ${ }^{17}$

In his book of selected poems, On These I Stand, Cullen would include twenty-one poems from Copper Sun, four of them concerning racial issues. Three of these four- "From the Dark Tower," "Threnody for a Brown Girl," and "The Litany of the Dark People" - appear frequently in anthologies today; not a single one of the others is ever chosen. Cullen's next collection, The Medea and Some Poems (1935), is composed mainly of Cullen's translated "version" of The Medea. The last third of the volume comprises twenty-seven poems on various subjects, few of which concern race. The one poem that most directly addresses racial injustice in the United States, "Scottsboro, Too, Is Worth Its Song," is the only poem from this volume that one finds in American and African American literature anthologies still in print today. For On These I Stand, Cullen chose eighteen poems from this volume. Racially themed poems make up about one-third of the selections in that collection; in many current anthologies all of the Cullen poems are overtly "racial," 
although a few do include one nonracial poem, usually "To John Keats, Poet. At Springtime." The only book of poems that was dominated by racial poems was his first, Color, and even in that one they comprised barely half of the total, a ratio roughly equal to what one finds in the selections from that book included in On These I Stand.

Knowing that Cullen was black is an inescapable factor in our response to-and therefore the effective meaning of-his poetry. (Theoretically, this may not always be the case.) This knowledge largely accounts for current interest in his verse, if we are to judge by the almost exclusive interest in his verse about blackness and racism in America. If Cullen's racial identity is crucial to the meaning of his "racial" poems, why should this not be the case for his verse on nonracial subjects? One might mount an argument about the subtle ways in which Cullen "blackens" standard themes and forms, but this seems to me to merely exacerbate the problem that he wished to evade, to reflect more of our own need for his race to signify in his poems than about his artistic singularity. I would prefer to draw attention to the ways in which Cullen "queers" or destabilizes racial expectations from his own day to ours, not because of something racial in his poems but because of the frisson caused by his resistance to the institution of "Negro poetry." His racial identity-or our awareness of it-remains, of course, instrumental to this effect.

Cullen had plenty of race pride, but he believed that resisting pressures to write mainly about race or in "racial" forms allowed him to defy the color line and to stand up for artistic integrity. He was far from alone in this. As Gene Jarrett has pointed out, many black intellectuals of the day (and later) felt that poetry and fiction not just on so-called universal subjects but specifically on white people by black authors would be revolutionary in the field of publishing. ${ }^{18}$ They questioned, however, whether any publisher would knowingly accept such work from black authors. In Cullen's case, they did —in the 1920 s and 1930s, but not thereafter.

\section{Passing}

I will now turn to the presentation of what many scholars would call the best novel of the Harlem Renaissance, Nella Larsen's Passing - a novel that takes as its subject, in part, the fear and fascination inspired by a woman who is both black and white. Told from a third-person limited point of view, with a middle-class black woman, Irene Redfield, as the 
center of consciousness, the novel focuses on this woman's relationship with a childhood friend, Clare Kendry, who has been passing for white and is married to a rich white businessman. Clare is described as pale white in complexion, with blonde hair and large, languorous black eyes. Originally of a lower status than the narrator and therefore treated as a kind of charity case by their circle of childhood friends, she was taken in by white aunts after her father, a mulatto, died during her youth. Removed from the neighborhood, she lost contact with her black friends, who on first seeing her years later with a white man assumed that she had begun supporting herself as a sort of high-class prostitute. Now thrown back in contact with Irene Redfield, she reveals that she has been married for twelve years to a white man and has a child by him who is, to all intents and purposes, white; but she wishes to reenter the black world and is not afraid of being "found out." What is curious about the novel, however, is that Irene Redfield, the center of consciousness, who is very much a "race woman," finds herself both attracted to and frightened by Clare Kendry. Above all, for a variety of reasons, she emphatically does not want Clare to become "black" again. At the end of the novel, just as her husband confronts Clare, at a black party, about her racial identity, Irene panics and apparently pushes Clare out of a sixth-story window to her death. There are many ways of interpreting the story, of course, but at its center is the luminous figure of a dark-eyed, pale blonde woman who is socially both black and white-a white woman who is "really" black; a black woman who is "really" white-and the tremendous danger associated with this self-positioning because of the fear it arouses in others. If she cannot be stabilized on one side or the other of the color line, she simply must be done away with.

The novel's subversion of the color line, its critique of the ways in which American racial identities depend upon the sacrifice of racial ambiguity or transracial identity, has important connections with Larsen's first, largely autobiographical, novel Quicksand, which focused on a biracial woman -a "black" woman with a Danish mother, raised in a white family after her mother remarried a white man, who was never able to find a home in the world. Among African Americans she had to hide the fact of her white parentage. Among white Americans she could not, of course, find a place because of her dark skin. In Denmark, her "mother country," she was treated as an exotic pet and recruited to advance the family's status through marriage. A final attempt to find her true home in the black Southern Christian community proves her most disastrous 
move of all. Larsen's interest in how the color line is reproduced at the expense of the interracial subject derived from her personal history, for she, like the heroine of her first novel, had a white Danish mother-a fact that was important to her self-understanding and closely linked to her literary inspiration.

The original dust jacket of Passing bore a geometrically patterned art deco design, with no reference on the front surface to the work's status as a "Negro" novel (although the inside flap and back of the jacket, respectively, would feature Larsen's racial identity and summarize the plot). The inside front flap, printing almost verbatim a short biography that Larsen herself wrote for Knopf's publicity department, reads as follows:

\section{NELLA LARSEN'S}

mother was Danish, her father a Negro from the Virgin Islands, formerly the Danish West Indies. When she was two years old her father died and shortly afterwards her mother married a man of her own race and nationality. At eight she and her half-sister attended a small private school whose pupils were mostly the children of German or Scandinavian parents. When she was sixteen she went to Denmark to visit relatives of her mother and remained there for three years.

On her return to America she entered a training school for nurses in New York and after graduating, accepted a position as Head Nurse of the hospital at Tuskegee Institute, but left after a year and went back to New York. She was admitted to the Library School of the New York Public Library and after graduating, worked as an Assistant and later as Children's Librarian in the New York Public Library until 1926. In April, 1928, she published her first novel, Quicksand, which has since been awarded the Second Prize in Literature and a bronze medal by the Harmon Foundation in its annual award for "distinguished achievement among Negroes."

This was the most accurate rendition of Larsen's life story in all of the editions of her novel until the very recent Norton Critical Edition edited by Carla Kaplan. In fact, it is the only one that is probably completely accurate. You will no doubt notice how much emphasis this biography gives to the unusual ethnoracial position Larsen occupied. The biography is a faithful representation of her upbringing and professional life. The 
biographical synopses in introductions to later editions of Passing both drastically reduce the attention paid to Larsen's interracial position and present false information that would assimilate her to a more normative model of black female identity, perhaps in part because biographical work through the 199os had come to the inaccurate conclusion that her autobiographical statement was fraudulent, a symptom of Larsen's need to cater to a white audience and/or "play up" her white connections. ${ }^{19}$ Yet such notions may themselves be overdetermined by scholarly desires to fit Larsen into the "family" of black women's literature.

The back flap of the dust jacket points out that Quicksand, Larsen's first novel, won the Harmon Foundation's second prize and excerpts reviews of that book from the New York World and the New York Times. Finally, the back of the dust jacket gives a partial plot summary of Passing: "The heroine of this novel is a beautiful colored girl who crosses the color-line into the white world. Her life as a white woman brings her superior advantages of almost every kind, and yet after a time there comes an inexplicable longing to go back to her own people. A chance meeting with a Negro school-mate-and she renews her old racial contacts, although she is aware of the accompanying danger and senses the tragedy that will undoubtedly overtake the double life she attempts to lead." This summary stresses the motif of the "double life" and the danger of being both black and white.

I might add that the physical presentation of the book, except for the dust jacket, ties it closely to Quicksand. That novel was published in brick-orange cloth with black scoring creating a kind of frame along the edges of the front cover. The typeface was Caslon Linotype. The book was dedicated to Larsen's husband and bore an epigraph from Langston Hughes's poem "Cross": "My old man died in a fine big house. / My ma died in a shack. / I wonder where I'm gonna die / Being neither white nor black." Passing's cloth cover is like an inversion of Quicksand'sblack cloth, with brick-orange scoring on the edges of the front cover in exactly the same design as the black scoring for Quicksand. The dimensions of the books are identical. The typeface chosen for Passing is once again Caslon Linotype. It is intriguing to consider that if Quicksand centers on a woman neither white nor black, Passing centers on a woman both white and black.

But there is another book to which the presentation of Passing bears comparison, as Beth McCoy has argued-Carl Van Vechten's controversial novel of 1926, Nigger Heaven, the first edition of which had the same 
dimensions as Larsen's novels and was also set in Caslon Linotype. ${ }^{20}$ (I should add that these dimensions and typeface were not unusual for Knopf novels at the time.) Larsen dedicated Passing to Carl Van Vechten and his wife Fania Marinoff (to whom Nigger Heaven was dedicated). Nigger Heaven used as an epigraph several lines from the last part of Countee Cullen's "Heritage"; Larsen draws her epigraph from several lines near the beginning of the same poem: "One three centuries removed / From the scenes his fathers loved, / Spicy grove, cinnamon tree / What is Africa to me?"

The dedication in the first edition is spread out to four lines, in large type-not only larger than the face used in the body of the book, but larger even than the novel's three major section-headings. Centered in the top half of the page, it makes a bold statement, for dedicating a novel to Van Vechten at this time was far from a neutral act. Future editions of Passing would in various ways both marginalize the dedication and reduce its visibility - by severely reducing the size of the type, confining the dedication to one or two lines, and/or setting it against a margin.

It has been argued that the dedication in the original edition registers not only the friendship between the author and the dedicatees, but the unequal power relations that made black writers dependent on white patrons, who in turn attempted to control their artistic production..$^{21}$ Indeed, it has been suggested that the dedication is a kind of disguise in readings that interpret Passing chiefly as a deliberate subversion of Nigger Heaven. However, at the time of publication, while Larsen certainly felt tremendous gratitude to Van Vechten and Marinoff-they were two of her best friends-she was not dependent on him for publication. In fact, she almost sent her novel, dedication and all, to Viking, a new house at the time that was trying to woo her away from Knopf and, more generally, attempting to build a distinguished list of titles by African Americans. Van Vechten ultimately persuaded her to stay with Knopf. Far from being the one mediator every black author needed to sell his or her books to New York publishers, as he is often represented in histories of the period, Van Vechten worried that his black friends-particularly Larsen and Langston Hughes-would drift away from Knopf to other presses, as both Walter White and James Weldon Johnson had done.

In a recent article on Larsen's Passing that focuses on the changes in typography between the original Knopf text and the Rutgers text of 1986, Beth McCoy observes that Passing was originally set in the same typeCaslon-as Van Vechten's Nigger Heaven, suggesting an important in- 
tertextual relationship between them that was erased when Rutgers put out its edition in the more modern Perpetua. But rather than reading this connection between the novels as a sign of cultural-political kinship-or, more probably, reflective of Knopf book designers' standard practices for novels of the time-McCoy uses it to mount an argument about Larsen's text as signifying on and undermining Van Vechten's. (Of course, her argument also implies that new editions of Nigger Heaven should also retain its "original" physical form.) We should recognize, she argues, the intertextual relationship between these works as a sign of the "difficulties of maintaining interracial friendships across lines of institutionalized inequity." 22

To make matters worse, Larsen "enters the complexly disturbing realm of the exceptional black woman in the context of the largely 'white' American Women Writers Series" - in other words, a priori, Larsen really belongs with other black women writers such as Jessie Fauset, and her being singled out plays into the white establishment's methods of promoting some minority authors as individuals at the expense of othersnotably Jessie Fauset-and the collective project of black women writers as a group.

"Typographical changes that bring volumes such as the Rutgers Passing ... into the visual mainstream can also functionally mute structural critique. When typography, along with other tools, is used to normalize the physical presence of African American literature, the sense of the works themselves as artifacts with both individual and cumulative force and aesthetic and political context can be lost, or at least diluted." ${ }^{23}$ That is to say, if a text is by an African American, it belongs a priori to a separate family of text and ought to bear the visual imprint of that filiation, that overdetermining difference. Just as one can argue that Larsen is the sister author to Jessie Fauset without any attempt to find out what she thought of Fauset and her work, so should one insist that the paratextual elements of black-authored texts signify their racialized alterity. The failure to so differentiate, we are warned, comports with the neoconservative and neoliberal dogma of "color-blindness" that argues blacks are the same as whites and justifies rolling back the gains of the Civil Rights movement. "And typography can shift Passing from its status as a very public response to Carl Van Vechten and the institutional power he wielded through Knopf to a series text that, in a sort of cosmetic sisterhood, is putatively 'the same as' other recovered texts by white women writers, such as 'Behind a Mask,' by Louisa May Alcott." ${ }^{24}$ The possibil- 
ity that Passing may actually share as much aesthetically and politically with Nigger Heaven - or various works by white women in the Rutgers series-as with Jessie Fauset's Plum Bun is simply inconceivable. The signs of intertextuality between Larsen's text and Van Vechten's can only be interpreted in terms of resistance, while Larsen's novel is presented as a kind of twin to Plum Bun. Of course, regardless of how Larsen herself thought of the relationship between her work and Van Vechten's, it is perfectly legitimate to locate points of conflict and subversion (intentional or not) between Nigger Heaven and Passing. But doing so may tell us as much about the desire of the present-day critic or editor and the prevailing structures of literary scholarship that shape that desire as about something "in" the text or historical context. An inherent, yet scarcely stated, biographical hypothesis about Larsen, Van Vechten, and Fauset turns on the racial identifications of the authors that divide them into their presumed spheres of affiliation, helping undergird the institution of "black representational space."

We can read the intertextual relationship between Nigger Heaven, Plum Bun, and Passing quite differently, however (which is not to say we must do so). In direct repudiation of Van Vechten, who had subtitled his infamous book "A Novel with a Moral," Fauset subtitled Plum Bun "A Novel without a Moral." (Perhaps coincidentally, Claude McKay gave his novel of the same year, Banjo, the subtitle "A Novel without a Plot.") The publishers of Plum Bun sent a prepublication copy to Larsen in hopes of getting a statement from her for publicity purposes. She failed to respond. ${ }^{25}$ Aesthetically and temperamentally, Larsen and Fauset had little in common, and they had strongly opposed views about Carl Van Vechten.

Larsen and her husband, Elmer S. Imes, were fans of Van Vechten's fiction before, during, and after the publication of Nigger Heaven in 1926. One of Elmer's favorite novels was Van Vechten's Peter Whiffle. Among Larsen's particular circle of black friends, Nigger Heaven was enthusiastically received. Lillian Alexander, an old Harlem friend of Nella and Elmer's, had objected to the novel based on reviews she read when it came out, but after reading it, she wrote Elmer specifically to apologize, citing how "dumb" the criticism of it was in the black press: "Really the book is an epic-to me-(and I rarely rave over anything or anybody) and is revealing in every line of Negro wants, needs, failures and why, aspirations and the vicious circle that prevents their realization." ${ }^{26}$ Rudolph Fisher's sister Pearl spoofed the criticism of the novel and of its title in her col- 
umn "This Harlem" for the Baltimore Afro-American. Rudolph himself had read the book in manuscript (as had Walter White and James Weldon Johnson), had encouraged Van Vechten, and had helped him with the "glossary." ${ }^{27}$ These were exactly the people with whom Larsen spent most of her intimate social life in the late 1920s. James Weldon Johnson wrote a review defending the novel for Opportunity. As I have shown elsewhere, Larsen was directly implicated in the black newspaper criticism of Nigger Heaven, which was as often an attack on Van Vechten's black friends as on Van Vechten himself, and specifically targeted his "dusky hosts-and hostesses" in Harlem, Nella Larsen being one of the chief of these. ${ }^{28}$ Plum Bun's ideological trajectory and plot structure, in any case, are virtually the opposite of Passing's. ${ }^{29}$

Instead of reading the dedication as an obsequious expression of Larsen's dependent status or a fetishistic expression of her ambivalence toward her "patron," we can read it as an assertion of artistic autonomy, indeed of independence from the demands of racial representativeness and uplift. The dedication made a deliberate cultural-political statement that could not have been missed by contemporary readers of "Negro" literature and literary criticism. Larsen was thumbing her nose at thoseincluding many black reviewers and Harlem neighbors-who had pilloried Nigger Heaven, much as Langston Hughes had done in 1927 by dedicating Fine Clothes to the Jew to Van Vechten. The dedication of Fine Clothes, along with the form and content of its poetry, much of which took the form of blues lyrics, prompted black critics to charge that the book was "designed for white readers" and that it showed how Hughes had been led astray by Carl Van Vechten. ${ }^{30}$ After taking the second draft of her first novel (Quicksand) in to Knopf, while Fine Clothes was being ripped to shreds in some quarters, Larsen wrote Carl, "Heaven forbid that I should ever be bitten by the desire to write another novel! Except, perhaps, one to dedicate to you. For, why should Langston Hughes be the only one to enjoy notoriety for the sake of his convictions?" From the moment she began writing Passing, Larsen planned to dedicate the book to Van Vechten, and she referred to it in correspondence as "his" novel. Could Larsen have been kissing up to Van Vechten? Of course. But more dramatic in the context of the moment was the fact that any fond acknowledgment of his friendship at the time virtually ensured notoriety and identified Larsen's fiction with Van Vechten's in the critical landscape of the late 1920s. Larsen was most emphatically not allying herself with, for example, Jessie Fauset. 
With both her first and second novels, Larsen thought she was risking ostracism by the same people who had attacked Van Vechten and Hughes. Ironically—and to Larsen's amazement-the same critics who railed against Van Vechten hailed Passing as an antidote to novels like Nigger Heaven, proving that black America had an intelligent and striving professional class-which, actually, was much more the propagandistic point of Van Vechten's own novel than of Passing.

Van Vechten himself was a huge fan of Passing. Larsen did not share it with him while writing it; she apparently wanted it to be a surprise. When he received his pre-publication copy, with its affectionate inscription by the author, he immediately started reading it - "absorbingly" he wrote in his diary-until he had to go out to dinner. When he got home from dinner at 1:00 a.m. he picked it up again and finished it at one sitting, calling it in his diary "an extraordinary story, extraordinarily told. I go to bed and sleep badly. I am so excited." ${ }^{31}$ The next morning he woke up, dressed, and immediately headed to the Knopf offices where, his diary records, "I stir Blanche and Alfred up about Nella Larsen's Passing, making quite a scene." ${ }^{32} \mathrm{He}$ then went next door to the American Mercury office and raved to George Jean Nathan about the book. Next he went to a florist's and ordered a bouquet of flowers for Larsen, and continued to the home of Dorothy Peterson-a black friend who was also Nella's best friend at the time-for lunch, where he found Nella herself. A few days later he went to the Knopf offices again to join in a conference with the Knopfs, an editor, two salesmen, and Nella Larsen to brainstorm about ways to market the book. This level of interest has no parallel in Van Vechten's response to other writing-by blacks or whites-of the period. (Of course, vanity may have been one reason for his enthusiasm.) One result of the meeting, apparently, was a unique marketing gimmick. Knopf quickly printed up some green paper "belly bands" to wrap around the middle of the jacket of the book with a bold blurb by Van Vechten. Blanche Knopf subsequently hosted a well-attended tea in honor of Larsen and her book at the elegant Sherry-Netherland Hotel and invited many of the literary lights of the city, along with Larsen's friends, both black and white.

In marketing the novel, Knopf used different strategies. One played up the "sensational" aspects of the novel without specifying them, making no reference to race or blackness. Van Vechten's blurb read: "A strangely provocative story, superbly told. The sensational implications of PASSING should make this book one of the most widely discussed 
on the Spring list." Probably the most important advertisement for the novel was that in Publishers Weekly, a full-page advertisement aimed at booksellers immediately before publication. Such ads are intended to get a book into bookstores nationwide - a difficult task for black-authored fiction in those days. "An ASTONISHING and SENSATIONAL Novel that will be widely advertised," it began. Knopf had written a special advertising letter (not uncommon for him), presented in an hourglass design over his signature. The letter never says a word about the race of the author or the racial content of the book, although the title might have given away the subject matter to most readers. Knopf, I suspect, was trying to persuade booksellers outside New York to adopt the title who normally would be skeptical of the sales potential of a "Negro" novel. "Passing is a novel on a theme so explosive that for a long time the advisability of its publication was seriously debated," Knopf disingenuously puffed. "But the complete artistry of its telling and the poignant interest of the story itself imperatively demanded that the book see the light of day." ${ }^{33}$ A different advertisement developed for literary reviews subsequent to publication explicitly identified the novel racially. Thus the New York Herald Tribune carried, along with a profile of Larsen based on an interview, an advertisement beginning "I like my ladies darker," quoting Irene Redfield's husband Brian. "Brian Redfield didn't like 'jigs' who passed for white," the text continues, "and he claimed that the pale beauty of Clare Kendry didn't compare with that of an 'A-number-one Sheba.' But he succumbed to the charms of this girl who was 'passing' ... who had married a white man ... who was accepted in white society. Then Clare's husband discovered the truth." ${ }^{34}$ The firm tried its best to create a sensation around the drama of passing: "There are thousands of Clare Kendrys, and every woman who 'passes' is a possible storm center. Nella Larsen knows her subject and around this sensational question she has written a fast-moving, action-filled story that will startle both $\mathrm{Ne}$ groes and whites."

The novel, unfortunately, did not do well commercially. Van Vechten continued pressing Knopf to market the book aggressively. Knopf wrote to assure him that the firm was doing all it could, but to little effect. Even in Chicago, the book's opening setting, where Knopf's sales force was pressing the bookstores to feature it, people weren't buying. The sales were limited almost exclusively to New York. ${ }^{35}$ Knopf brought out a third printing (the one in which the final paragraph of the original was unac- 
countably dropped) in hopes that interest would pick up-the novel was getting positive reviews-but obviously expected to lose money on that printing. It seems unlikely that the Knopfs made back their investment in the novel, and it soon went out of print.

Forty-two years later a new edition of Passing appeared in the form of a 1971 Collier Books paperback introduced by Hoyt Fuller, editor of the journal Black World and an important proponent of "the Black Aesthetic" in the late 1960s and early 1970s. This book appears in a series called the African/American Library: "A continuing series of works of literary excellence by black writers in the United States, Africa, and the Caribbean." The cover illustration shows African Americans in an urban setting suggesting the Great Depression. The front cover, under the title, has this marketing blurb: "The tragic story of a beautiful light-skinned mulatto passing for white in high society, who sought dangerously-and too late-to claim her black heritage. A searing novel of racial conflict in the 1930s." Fuller's introduction recalls the initial reception of the book and then rejects interpretations from "without" the black community. It also states that Larsen, like the two main characters of the novel, "had gone off to Europe for a try at rejecting her Blackness, only to return in the end to wrap it closely about her again." A footnote adds, "At one point, Miss Larsen left her husband, Dr. Elmer Imes, and went off to live in Europe. Reportedly, she considered ending her marriage and becoming the wife of an Englishman. However, she finally returned to America and to Dr. Imes." ${ }^{36}$ That is all we get of Larsen's biography, and it is essentially inaccurate. (The truth is actually the opposite: Larsen learned that her husband was having an affair with a white woman just about the time she was awarded a Guggenheim to go to Europe and work on a novel. About a year after her return she divorced her husband because of his infidelity; the white lover would remain his partner for life.) The biographical inaccuracies concern me less than the attempt Fuller makes to direct the reader toward an understanding of the novel as affirmation of an undiluted black heritage. Yet the novel is hardly black enough for Fuller, who finds its subject matter trivial, justifying the fact that black readers have ignored it and its author: "Current interests lie in other, less white-oriented directions." ${ }^{37}$ Even in the 1920s, Fuller adds, "not all that many Black people were worked up over passing": "apart from the malicious delight Black people derived from having one of their own get away with such a masquerade, passing no doubt ranked very low in the 
essential scheme of things." ${ }^{38}$ In other words, white audiences are primarily responsible for the appearance of Larsen's novels.

It is very clear from the black-authored reviews of Passing (and Quicksand) in the 1920 s that many black readers of the time considered these the sorts of novels that blacks would enjoy more than whites. Of Quicksand, W. E. B. Du Bois stated simply, "White people will not like this book." The truth is that some white people and some black people liked Larsen's books, but most potential readers-white and black-ignored them.

Larsen's attention to upper-class light-skinned characters Fuller attributes to her desire to present a favorable impression to the white public, to advertise the existence of a black bourgeoisie. "It is all rather banal ... In the tradition of mulatto writers since William Wells Brown ... Miss Larsen dwells on the 'white' traits of her 'society Negro' characters." ${ }^{39}$ "Without the element of intrigue and suspense injected by race," Fuller's introduction concludes, "Miss Larsen's novel might have been relegated to the lost ranks of that massive body of fiction designed to titillate middle-class housewives on a long and lonely afternoon." ${ }^{40}$ Between the cover illustration, the blurb material, and the argument of the introduction, a particular racial/ethical orientation envelops the text. The cover attracts an audience looking for "black" fiction of the urban underclass, the front matter listing titles in the series places the book within a black diasporic canon, and the introduction relegates the text to the dustbin of history for not being about what the cover illustration seems to suggest.

The next significant edition of the novel is Deborah E. McDowell's, for the American Women Writers Series of Rutgers University Press (1987). This book set off a new phase in Larsen's reception, publishing Larsen's two novels together at the very moment black feminist criticism and black women's fiction were gaining new footholds in the academy and the publishing industry. In her influential introduction, Deborah E. McDowell argued that the novels were not really about biracial identity or passing but rather about black female psychology and sexuality. As if to signal this new understanding, the cover of this book features a wellknown photograph by the Harlem photographer James Van der Zee of three well-dressed, unmistakably African American women of the $1920 \mathrm{~s}$ strolling joyously, arm in arm, down a broad Harlem sidewalk. Celebrating three evidently middle-class black women's friendship, the photograph has little in common with either of Larsen's novels.

On the back cover, one finds two blurbs, one by Alice Walker and one 
from the Women's Studies International Forum, the latter reading, "A tantalizing mix of moral fable and sensuous colorful narrative, exploring female sexuality and racial solidarity." A brief description of the contents reads, "Nella Larsen's novels Quicksand (1928) and Passing (1929) document the historical realities of Harlem in the 1920s and shed a bright light on the social world of the black bourgeoisie. The novels' greatest appeal and achievement, however, is not sociological, but psychological. As noted in the editor's comprehensive introduction, Larsen takes the theme of psychic dualism, so popular in Harlem Renaissance fiction, to a higher and more complex level, displaying a sophisticated understanding and penetrating analysis of black female psychology."

Deborah E. McDowell's introduction steers readers away from concentrating on interracial identity or passing to argue that the novels are fundamentally about black female sexuality. The biographical information provided matches this emphasis. We find less detail than in the dust jacket of the first edition about Larsen's family and are told she never felt connected to that family anyway. Roaming from place to place, Larsen finally studied science for a year at Fisk, we are told, during a rocky marriage to professor Elmer Imes, then traveled to Denmark where she audited classes at the University of Copenhagen; then she returned to the States and studied nursing, and so on. Not only are the facts wrong-understandably, given the state of Larsen biography at the time-but they give a very different notion of what is significant in the author's life than what Larsen presented, deliberately, to her publisher for publicity purposes.

Similarly, McDowell strives hard to discount the notion that Passing is about passing or racial ambiguity and ambivalence; its chief concern is with black female sexuality, and its chief weakness is that it does not address this issue as forthrightly as it should. Larsen's failure in this respect, McDowell argues, can be attributed to the oppressive atmosphere of the time, when black women authors had to take care not to nourish stereotypical notions of black women's hypersexuality. In particular, Carl Van Vechten's novel Nigger Heaven had made it "difficult to publish novels that did not fit the profile of the commercial success formula adopted by most publishers for black writers."' ${ }^{41}$ In essence, McDowell makes a point closely related to Fuller's: If it hadn't been for the hegemony of white notions about race (specifically, for McDowell, black women), perhaps Larsen would have had the courage to develop her talent in more fruitful directions.

Knowing that Van Vechten was Larsen's friend, McDowell speculates 
that Larsen found herself between a rock and a hard place, unable to come out directly against Van Vechten. That Passing is actually dedicated to Van Vechten and his wife is put in perspective by the speculation that, since Van Vechten had helped her get her first novel published, "perhaps Larsen showed her gratitude by dedicating her novel to him and his wife Fania Marinoff." ${ }^{42}$

But let me return to the packaging of Passing. As we've seen, Larsen had given her novel an epigraph from Countee Cullen's poem "Heritage" that focused on the ambiguities of racial identity and the question "What is Africa to me?" This epigraph, boldly featured in the first edition, is reproduced in the Rutgers edition on the verso of the dedication page in minuscule type. Moreover, in the introduction, McDowell brushes off the epigraph as "misleading." ${ }^{43}$ "Focusing on racial identity or racial ambiguity and cultural history, the book invites the reader to place race at the center of any critical interpretation," but this is merely a piece of camouflage, forced on Larsen by the racism and heterosexism of the $1920 .^{44}$ Larsen's unfortunate compromise with reigning prejudices, we learn, is compounded by the matching inappropriateness of the novel's ending, in which Clare Bellew, the "passing" heroine, is pushed to her death by the novel's center of consciousness, Irene Redfield. The story of lesbian attraction between these women, according to McDowell, was too dangerous to expose, and so Larsen wrapped her real concerns in the misleading guise of the "safe and familiar plot of racial passing." 45 Such a hypothesis is inherently biographical, and yet it sidelines the possibility that Larsen was, for example, investing Irene Redfield with her own fears about losing her husband to another woman (who was white) at the time she was writing Passing. McDowell ends with a devastating critique of the novel for honoring "the very value system the text implicitly satirizes." ${ }^{\prime 6}$ Larsen does "the opposite of what she has promised." But McDowell goes on to suggest that the novel did, after all, anticipate later, more explicit and satisfying treatments of black female sexuality by African American women authors such as Toni Morrison, Alice Walker, Gloria Naylor, Gayl Jones, and Ntozake Shange. This sisterhood, we understand, is where Nella Larsen really belongs.

As if following upon McDowell's point, the Modern Library commissioned Ntozake Shange to do the introduction for its new edition of Passing, the back cover of which has a blurb by Alice Walker and an excerpt from Shange's introduction. The front cover is graced by a photograph of Larsen by Carl Van Vechten. ${ }^{47}$ Shange's brief and ambivalent introduc- 
tion, in some ways like Hoyt Fuller's, focuses on the question of racial betrayal. Shange judges Clare Kendry a negative force who "tortures" Irene Redfield by asking to be taken to Harlem events, "as if Irene were there for her amusement, to see Negroes, not unlike the hordes of whites who invaded Harlem at the time to look at us, to dance our dances, to guess who among us was more white than the others." ${ }^{48}$ Clare, in Shange's presentation, is like a white woman touring black Harlem and making invidious color distinctions among its populace. (In the context of the present discussion, this statement is ironic, in that Van Vechten and his wife occasionally escorted Larsen to the NAACP dances, since her husband did not like to go.) The entire novel, by Shange's account, is an indictment of the central characters; Larsen "bluntly exposes the classism and racism of this small clique of our population." ${ }^{49}$ Given this critique of the main characters, who all seem to suffer intense ambivalence about the enclosure of race, one can't but take as a warning to self-described "multiracial" persons at the turn of the twenty-first century Shange's concluding moral that "Larsen has peeled away the historical questions we might have about society during the Harlem Renaissance, while remaining relevant in an America whose biracial population is growing. She offers characters so honest and desperate to be whole that we cannot help but champion their humanity." ${ }^{50}$ Shange's introduction brims with anxiety about the destabilization of racial identities in the late 1990s, when questions about racial categorizations for the 2000 census grew acute.

On this note, it is worth pointing out a similarity between the cover of the 1997 Penguin edition of Passing, introduced by Thadious Davis, and that of the 1990 Beacon Press edition of Plum Bun, the classroom standard edited by Deborah McDowell. They use an identical portrait by Archibald Motley, drawn from his series on African American "types" categorized by supposed blood fractions, and tell us that these books are sister texts about so-called octoroons. In the version for Passing, the skin has been lightened perhaps to fit the description of the alabastercomplected Clare, though it does not render her blonde hair. Like the publishers of other "passing" novels in recent years-see, for example, recent covers for Iola Leroy, whose protagonist, like Clare, is blonde-the book designers did not wish to confuse their clientele by putting a blonde woman on the cover of these "black" novels lest it provoke precisely the sort of category crisis Larsen, in particular, seems to have intended.

At the beginning of Passing, Irene is sitting in a restaurant wondering why a blonde white woman is staring at her, thinking, surely she can't tell 
that I'm really black; white people are always so stupid about such things. In fact, the white woman is not only "black" but Irene's old friend, Clare; and Irene does not realize the fact until Clare tells her directly. Neither, of course, does the reader. In a departure from the convention of identifying black characters racially from the moment they are introduced into a text, Larsen deliberately withheld the racial identity of Irene until page 18 of the first edition, in the second chapter, when Irene asks herself, "Did that woman, could that woman, somehow know that here before her very eyes on the roof of the Drayton sat a Negro?" The question has a performative dimension since it is the very gesture through which the reader, accustomed to "unmarked" characters being white, suddenly realizes that Irene is a Negro. Yet Clare's identity is withheld even longer (to page 22 in the first edition), so that Larsen can heighten the ironic turn when Irene (and thus the reader) suddenly realizes that the "white" woman who has been staring at her is herself a Negro, and not only that but an old friend she doesn't recognize because she thinks of the woman as white. An interesting experiment would be to put the portrait of a blonde, apparently white woman on the cover of Passing, yet to do so might imperil that edition's sales unless other external markers-or growing familiarity with Larsen in the book-buying public-identified the novel as Black.

While Fauset and Harper use the blonde "passing" heroine to affirm racial differentiation and to look toward a New Negro future severed from intimate relations with whites, Larsen's novels may, in contrast, suggest that the attempt to make one's peace with racial seclusion by embracing its logic is only another dead end in an elaborate trap. One can certainly argue with this stance or question whether this is really Larsen's position. Yet the presentation of her texts has made it inconceivable. Thus the relationship of a novel such as Passing to constructions of racial tradition, and its marketing within the parameters of such categorization, tends to blunt its unsettling power while affirming a distinction through which the novel appears as a minority within a minority - merely a special case of a certain type of African American fiction. The minority/majority distinction can accommodate this positioning quite well.

Larsen quite likely wanted her novel to be judged independent of racial categorization, even as she presented an unprecedented exploration of the psychology of black and white racialization in relation to women's sexuality. Her next novel, like her first two published short stories, featured suburban white characters and again focused on women's 
sexuality and marital dysfunction. Arna Bontemps, hearing of this novel from Larsen's ex-husband Elmer Imes in the early 1930s, wrote Langston Hughes that he eagerly awaited its publication, evidently suspecting it would mark a breakthrough for black authors. Rejected by Knopf, the manuscript is lost.

Notes

1. Darby English, How to See a Work of Art in Total Darkness (Cambridge: MIT Press, 2007), 6-9. I dedicate this essay to Oscar and Jazz.

2. This point has been made, particularly with respect to textual studies and editorial theory, in John K. Young, Black Writers, White Publishers: Marketplace Politics in Twentieth-Century African American Literature (Jackson: University of Mississippi Press, 2006), 7-10.

3. Gerald Early, "Introduction," My Soul's High Song: The Collected Writings of Countee Cullen, ed. Gerald Early (New York: Anchor Books, 1991), 3-6.

4. See, for example, Alain Locke, ed., The New Negro (1925); Sterling Brown et al., eds., The Negro Caravan (New York: Citadel, 1941); Arthur P. Davis and Saunders Redding, eds., Cavalcade: Negro American Writing from 1760 to the Present (New York: Houghton Mifflin, 1971); Richard Barksdale and Keneth Kinnamon, eds., Black Writers of America: A Comprehensive Anthology (New York: Macmillan, 1972); Deirdre Mullane, Crossing the Danger Water: Three Hundred Years of Afro-American Writing (New York: Doubleday, 1993); Rochelle Smith and Sharon L. Jones, eds., Prentice Hall Anthology of African American Literature (Upper Saddle River, NJ: Prentice-Hall, 200o); Patricia Liggins Hill, ed., Call and Response: The Riverside Anthology of the African American Literary Tradition (Boston: Houghton Mifflin, 1998); Anthology of American Literature, vol. 2, ed. George McMichael et al., 7th ed. (Upper Saddle River, NJ: Prentice Hall, 2000); The Norton Anthology of American Literature, ed. Nina Baym et al. (New York: W. W. Norton, 2011); The Heath Anthology of American Literature, ed. Paul Lauter et al. (New York: Wadsworth, 2008 and other editions); Anthology of Modern American Poetry, ed. Cary Nelson (New York: Oxford University Press, 200o); The Black Poets, ed. Dudley Randall (New York: Bantam, 1971); Voices from the Harlem Renaissance, ed. Nathan Irvin Huggins (New York: Oxford University Press, 1976); Black Voices, ed. Abraham Chapman (New York: Penguin/Mentor Books, 1968); Dark Symphony, ed. James A. Emanuel and Theodore L. Gross (New York: Free Press, 1968); Norton Anthology of African American Literature, ed. Henry Louis Gates Jr. et al. (New York: Norton, 1997); and Norton Anthology of Modern Poetry, ed. Richard Ellmann and Robert O’Clair (New York: W. W. Norton, 1988 and other editions).

5. "Heritage," Box 164-22, folder 4, Moorland-Spingarn Research Center, Howard University. As far as I know, scholars have yet to notice this version.

6. Jeremy Braddock has discussed the different published versions of "Heritage" and Cullen's correspondence with Locke at the time he was composing it (Spring 1923), in "The Poetics of Conjecture: Countee Cullen's Subversive Exemplarity," Callaloo 25, no. 4 (Fall 2002): 1250-71. 
7. James Kelley, "Blossoming in Strange New Forms: Male Homosexuality and the Harlem Renaissance," Soundings 80, no. 4 (Winter 1997): 507-11. Contrary to Kelley's speculations, it appears that "Locke's" version of "Heritage" was closer to the earliest typescript version by Cullen than was the version Cullen later used in his own selected poems.

8. Kelley (511) and Braddock (1267) have previously discussed this positioning.

9. Countee Cullen, “The Dark Tower," Opportunity 5 (1927): 210.

10. See George Hutchinson, The Harlem Renaissance in Black and White (Cambridge: Harvard University Press, 1995), 414, 526 n.39.

11. See George Hutchinson, In Search of Nella Larsen (Cambridge: Harvard University Press, 2006), 186.

12. Caroling Dusk, ed. Countee Cullen (New York: Harper \& Brothers, 1927), xi.

13. Countee Cullen, Introduction, Caroling Dusk, xi.

14. I discuss Braithwaite as anthologist and publisher in The Harlem Renaissance in Black and White, 350-60.

15. Kelley, 511. Kelley states, mistakenly, that the Charles Cullen illustration for "Heritage" preceded The New Negro, but the illustrated version of Color, including "Heritage," was in printings from 1927 on, after Locke's anthology.

16. Very useful discussions of Charles Cullen's working relationship with Countee Cullen and on other Harlem Renaissance texts can be found in Caroline Goeser, Picturing the New Negro: Harlem Renaissance Print Culture and Modern Black Identity (Lawrence: University Press of Kansas, 2007), 130-32, 253-56.

17. Another discussion of the tension between Cullen's "representative" racial status and his sexual orientation is Peter Powers, “"The Singing Man Who Must Be Reckoned With': Private Desire and Public Responsibility in the Poetry of Countée Cullen," African American Review 34 (2000): 661-78. It is implicit, as well, in Kelley's article and other studies that treat Cullen's poetry in relation to his sexuality, which include Amitai Avi-Ram, "The Unreadable Black Body: 'Conventional' Poetic Form in the Harlem Renaissance," Genders 7 (1990): 32-46; Aldon Reimonenq, "Countee Cullen's Uranian 'Soul Windows,' Critical Essays: Gay and Lesbian Writers of Color, ed. Emmanuel S. Nelson (Binghamton: Haworth Press, 1993), 143-65; and A. B. Christa Schwarz, Gay Voices of the Harlem Renaissance (Bloomington: Indiana University Press, 2003), 4867.

18. See Gene Andrew Jarrett, Deans and Truants: Race and Realism in African American Literature (Philadelphia: University of Pennsylvania Press, 2007).

19. See, for example, Charles R. Larson, Invisible Darkness: Jean Toomer and Nella Larsen (Iowa City: University of Iowa Press, 1993), xviii-xix, and Davis, 22. Startlingly, even Carla Kaplan's recent Norton Critical Edition of Passing, published after major features of Larsen's story of her life-that she lived with her mother throughout her youth, that she visited Denmark as a young child and again as a teenager-had been confirmed in the most recent biography, includes a chronology that presents that as only one "version" of her life, surely an almost unprecedented practice for a simple chronology, and one that the editor told me was required by the publishers.

20. Beth McCoy, "Perpetua(l) Notion: Typography, Economy, and Losing Nella Larsen," in Paul Gutjahr and Margaret L. Benton, eds., Illuminating Letters: Typogra- 
phy and Literary Interpretation (Amherst: University of Massachusetts Press, 2001), 97-114.

21. The most recent and extended such argument is Beth A. McCoy's "Speaking of Dedications: Carl Van Vechten and Nella Larsen," Intertexts 8, no. 1 (Spring 2004): 3754.

22. Paul Gutjahr and Margaret L. Benton, "Introduction," 96.

23. McCoy, "Perpetua(l)," 113.

24. McCoy, "Perpetua(l)," 113.

25. See Mary Mackay to Walter White, 12 February 1929, NAACP Papers, and "Copy of form letter to N.A.A.C.P. list of 350" from Frederick Stokes Co., 6 March 1929, Walter White Papers, NAACP Papers, LOC; and Carl Van Vechten 1929 Daybook, 23 February 1929, Box 111, CVV Collection, NYPL.

26. Lillian Alexander to Elmer S. Imes, 23 October 1926, quoted in George Hutchinson, In Search, 211.

27. Hutchinson, In Search, 205.

28. Hutchinson, In Search, 214. The quoted phrase is from Hubert Harrison's "Homo Africanus Harlemi," Amsterdam News, 1 September 1926, 20.

29. I discuss the extensive, and strikingly precise, inversions of plot elements between Plum Bun and Passing in In Search, 315-16.

30. J. A. Rogers, review of Fine Clothes to the Jew, Pittsburgh Courier, 12 February 1927 , section 1, p. 4. I should add that the physical book design may indeed have been developed to appeal to white readers, the majority audience; but this is not what the critics chiefly had in mind.

31. 3 April 1929, Carl Van Vechten Daybook of 1929, Carl Van Vechten Papers, Rare Books and Manuscripts Division, New York Public Library. I discuss this episode and other aspects of the marketing of Passing in greater detail in In Search, 318-20.

32. Entry for 4 April 1929, Carl Van Vechten Daybook for 1929.

33. Advertisement for Passing, Publishers Weekly 65 (13 April 1929): 1780.

34. New York Herald Tribune, 5 May 1929, n.p., JWJ Clippings 2 Personal and Corporate Names L-Led, Yale Collection of American Literature, Beinecke Rare Book and Manuscript Library, Yale University. Image available at http://beinecke.library.yale. edu/dl_crosscollex/brbldl_getrec.asp?fld=img\&id=1011428.

35. Alfred A. Knopf to Carl Van Vechten, 28 May 1929, Carl Van Vechten Papers, New York Public Library.

36. Hoyt Fuller, "Introduction," in Nella Larsen, Passing (New York: Collier/Macmillan, 1971), 12, n. 1.

37. Fuller, 14.

38. Fuller, 14.

39. Fuller, 18-19.

40. Fuller, 24.

41. Deborah E. McDowell, "Introduction," in Nella Larsen, "Passing" and "Quicksand," ed. Deborah E. McDowell (New Brunswick: Rutgers University Press, 1986), xv, quoting Amritjit Singh.

42. McDowell, $x v$.

43. McDowell, xxiii. 


\section{PUBLISHING BLACKNESS}

44. McDowell, xxiii.

45. McDowell, $x x x$.

46. McDowell, $\mathrm{xxx}-\mathrm{xxxi}$.

47. I should point out that a later printing of the Modern Library edition (2002) has a different cover and includes a long "Critical Foreword" by Mae Henderson.

48. Shange, "Introduction," in Nella Larsen, Passing (New York: Modern Library, 2000), xi.

49. Shange, xii.

50. Shange, xiii-xiv. 


\title{
John K. Young
}

\section{“QUITE AS HUMAN AS IT IS NEGRO"}

\author{
Subpersons and Textual Property in \\ Native Son and Black Boy
}

For fifty-one years, everyone read the wrong version of Native Son. Black Boy met a similar fate for thirty-two years, though readers could have stitched together the clues to that textual mystery, if they were especially determined. The only publicly available versions of these works, which continue to define Richard Wright's career, were those he revised at the request of the Book-of-the-Month Club and his influential editor at Harper \& Brothers. American Hunger, originally the second half of Wright's autobiography, finally appeared on its own in 1977 (though sections had been serialized in 1944 and 1945, surrounding Black Boy's original publication in the last year of the war), while the original version of Native Son remained invisible until Arnold Rampersad used it as copytext for his 1991 Library of America edition of Wright's Later Works. HarperCollins, the current instantiation of Wright's original publisher, now issues both the "Abridged" and "Restored" editions of Native Son, along with the "Restored" Black Boy, with revisions for the first editions now relegated to notes. While the rhetorical marker of a "Restored" edition bestows agency on the editor's recovery of a lost original, the "Abridged" designation elides the Book Club's consistent muting of Wright's sexual and political content, as if the manuscripts had simply run long. ${ }^{1}$

Those scholars subscribing to an intentionalist editorial theory will surely prefer the "Restored" editions. No record survives of Wright's response to changing Native Son, but he clearly resisted cutting the second half of American Hunger and then adjusting its conclusion (and title) accordingly, despite numerous efforts to make those revisions satisfactory to Dorothy Canfield Fisher, the renowned novelist who was also a prominent Book Club judge, and someone considered "sympathetic 
to the Negro cause" by the standards of the day. In any case, Wright's acquiescence to the Book-of-the-Month Club, one of the most powerful agents of literary promotion in the 1940s, represents from an intentionalist perspective a choice between tremendous commercial success and individual authenticity. The need for an intentionalist restoration is especially poignant in the case of these landmark works of African American literature, as Wright's testimony to the material realities of racialized life in Chicago and the South is refracted, as if by iodine, through the white sphere of literary production.

On the other hand, the original published editions of Native Son and Black Boy would hold greater historical weight for a materialist editorial approach, precisely for what they reveal about the social circumstances of production. By reading the "Abridged" versions of these works, we can see what kinds of images of black male sexuality, for example, could be published and marketed on a mass scale in the early 1940s United States: Wright's compromises and the resulting texts speak more eloquently than their original versions to the dilemma that James Weldon Johnson famously called "a special problem which the plain American author knows nothing about-the problem of the double audience." John Bryant usefully summarizes the divergent orientations of these editorial theories: "the two differ in their historicisms, the one seeking a private past, the other a public past. Both isolate crucial components of a culture: the inner workings of creative originating mind(s) to construct a text of the work; the interactions of texts and readers in a social sphere."3 The compromise Bryant proposes, a theory of textuality as fluid, seeks to bridge this divide by bringing both "private" and "public" versions of a work together on a page or screen, so that readers may appreciate fluid texts as "the material evidence of shifting intentions" (9; original emphasis). Similarly, Peter Shillingsburg finds that while a work (understood as an immaterial collection of material texts) does not reside in any single document or version, "[e] ach version implies the work in a different way; in juxtaposition, the versions imply the work in a more complex way."

Like Bryant and Shillingsburg, I would rather read both versions of Native Son and Black Boy in juxtaposition than adjudicate between them for a "correct" or "definitive" edition. (In practice, I have ordered both editions of the novel from the campus bookstore, so that two halves of a modern fiction course can gradually discover how each Native Son interacts with the other.) Indeed, I would argue that such a "both/and" editorial method is especially appropriate for most African American modernist literature, as the ostensibly private sphere of authorial compo- 
sition and revision has already been rendered troublingly public through Du Bois's double consciousness. Native Son is hardly the first text to be revised before publication in accordance with the marketing pressures of more culturally conservative readers, but the category of race-as produced historically in terms that conjoin ideology and aestheticsputs particular pressure on conventional notions of the public/private distinction between manuscript and print. Because the public sphere of literary reception is largely defined through what the philosopher Paul Taylor terms "thick racialism, which holds that the physical differences between races are signs of deeper, typically intellectual and moral, differences," the assumed autonomy of the private sphere of composition and revision is compromised by the need to produce a textual self in accordance with (or in opposition to) thick racialist aesthetics. ${ }^{5}$

The interesting and productive question is then not which version of Native Son or Black Boy to privilege but rather how to read their manuscript and published editions in mutual relation, for what they reveal about both Wright's authorial choices and the social spheres circumscribing them. In his 1937 essay "Blueprint for Negro Writing," Wright laments that African American texts of this period could function only as either "a sort of conspicuous ornamentation" or "the voice of the educated Negro

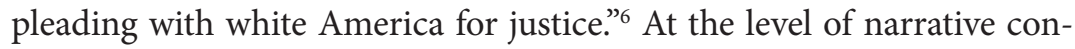
tent, both Native Son and Black Boy reject this false dilemma, condemning the entire racist structure of midcentury American society rather than pleading for justice from it. At the same time, the rhetorical effects of both works' revision and marketing reinforce the dichotomy Wright interrogates in "Blueprint." Whereas the narrative voice in each text implies an authorial position well beyond the unspoken publishing premise that "all non Anglo-Saxons are uncomplicated stereotypes," as Zora Neale Hurston opined ten years after Native Son, in "What White Publishers Won't Print," the revised implied author of Black Boy and the advertised author of Native Son bracket off cultural complications from their marketing images. $^{7}$ In this interaction of versions, between Wright's compositional and publishing decisions, and between each text's linguistic and bibliographic contents, lies the real story of Native Son and Black Boy.

\section{I. "A bit on the raw side": Revised Sexuality in Native Son}

By August 1939, Wright had completed a year of intensive composition and revision for his first novel, with publication scheduled for the fall. 
Harper \& Bros. sent a bound set of page proofs, intended as a reviewer's copy, to the Book-of-the-Month Club judges committee instead, with word quickly returning of their interest. By August 22, Wright's editor, Edward Aswell, wrote:

\begin{abstract}
And incidentally the Book Club wants to know whether, if they do choose Native Son, you would be willing to make some changes in that scene early in the book where Bigger and his friends are sitting in the moving picture theatre. I think you will recognize the scene I mean and will understand why the Book Club finds it objectionable. They are not a particularly squeamish crowd, but that scene, after all, is a bit on the raw side. I daresay you could revise it in a way to suggest what happens rather than to tell it explicitly. ${ }^{8}$
\end{abstract}

In the Wright archive at Yale's Beinecke Library, as well as the Harper \& Bros. files at Princeton's Firestone Library, no documents survive to indicate Wright's response to this request. As Hazel Rowley notes, "What we do know is that he agreed to the cut. And soon he would find himself agreeing to further changes" (181). The scene in question occurs early in the narrative, when Bigger Thomas and his friend Jack go to a movie, killing time before their planned robbery, and engage in a masturbation contest while waiting for the picture to begin. Most of the further revisions made at the Book Club's request further mute the sexual portrayals of Bigger and Mary Dalton, so that she becomes a significantly less active figure, both in relation to Bigger and her boyfriend, Jan. In addition, the Book Club judges sought changes to various comments and speeches made at Bigger's trial by his Communist and Jewish attorney, Boris Max, similarly dampening Max's rhetorical effect. ${ }^{9}$

Before examining the juxtaposed movie scenes in greater detail, I will first outline the important relationships among Wright, his editor, and his agent, Paul Reynolds. Both figures were significant enough in Wright's career that he dedicated his final published novel, The Long Dream, "To my friends Edward C. Aswell and Paul R. Reynolds, whose aid and counsel made this book possible." A Nashville native and Harvard graduate, Aswell fit the profile of an editor hostile to a young African American writer; indeed, he would observe to Wright nearly twenty years after their first meeting, "In the beginning you had every reason to be suspicious of me and you were" (quoted in Rowley, 140). From the start, however, Aswell championed Wright's work, and the two men forged a 
personal connection across racial boundaries. In 1957, after Wright had rejoined his former editor, then at Doubleday, Aswell wrote, "I like to recall how both of us broke down the false barriers that stood between us until at last we could meet man to man and after that, free communication between us became possible." ${ }^{10}$ Reynolds also recognized the aesthetic and psychological dimensions of Wright's relationship with his editor, as well as with the publishing firm behind him, initially advising Wright against leaving Harper because of the professional environment Aswell would be joining at McGraw-Hill (his job in between Harper and Doubleday). (Reynolds, incidentally, lived across the street from Aswell in Chappaqua and offered professional advice when Aswell was weighing job offers.) In June 1947, Reynolds advised:

I'm not at all sure how long Ed Aswell will stay with Whittlesey House [a McGraw-Hill subsidiary] or how much authority he will have there, and the executives who run the house I think you'd feel were pretty reactionary and wouldn't be very sympathetic to your point of view. In other words, if you think you should leave Harpers I think it would probably be wiser to go to some other house than Whittlesey House. . . . You want to have a good publisher who is going to be sympathetic and helpful to your point of view. We want to be sure you don't have a publisher who might be trying in small ways to censor what you wanted to say or who might not be willing to push a book if he personally disagreed with what you are saying. (Richard Wright Papers)

At the time of this letter, Wright was only two years removed from Black Boy's best-seller success and presumably could have commanded lucrative advances from any number of publishers, thus affording him the relative freedom to publish with a more politically supportive firm (though most contemporary readers would certainly find that Harper itself was "trying in small ways to censor" Wright's work). Thus, in evaluating circumstantially Wright's agreement to the revisions requested by the Book-of-the-Month Club for his first novel, we should factor in not only the obvious commercial difference a Book Club selection would make, but also Wright's trust in Aswell's opinion. While Wright's first book, Uncle Tom's Children, had won a Story magazine competition and "caused a splash" upon its publication in 1938 (Rowley, 142), its relatively light sales would hardly have been sufficient for Wright to reject the Book Club 
opportunity on the basis of his commercial status at the time (assuming he would have preferred to do so), nor for Aswell to have advised him along those lines.

Turning to the movie scene itself, both as expressive of the kinds of changes made elsewhere in the narrative and as the starting point in the chain of revisions made for the Book Club, the most significant alterations involve another movie screening during Bigger and Jack's stay, titled The Gay Woman, and the omission of the masturbation contest as well as a subsequent newsreel showing Mary Dalton's family vacationing in Florida. While Wright's original version follows the black male masturbation scene with the image of a wealthy white woman and shifts from there to a feature film set in Africa, Trader Horn, the revised version replaces these scenes with an innocuous newsreel and a melodrama about an adulterous wealthy woman who reconciles with her husband after he has nearly been killed in a Communist plot, then shifts to Trader Horn as a second feature. ${ }^{11}$ Portions of each episode follow.

The manuscript version would hardly have been the first instance of male masturbation in print, but certainly Wright's description is both more casual and more explicit than the norm in American fiction of this period. But as Aimé J. Ellis points out, Bigger has no private domestic space in which such actions could occur, given that he and his family share cramped quarters in their Black Belt apartment.

Thus, Ellis argues,

Inextricably connected to a culture that appears to emasculate, maim, and desexualize, and in every conceivable way castrate black male subjectivity, masturbation can be interpreted not only as an oppositional gesture but also as a 'humanizing' practice that may not be deemed as altogether subversive but that nonetheless can be understood as an enabling assertion of the self. ${ }^{12}$

Along these lines, it is worth remembering that Bigger's and Jack's masturbation occurs with no specific visual object on screen, though they will next see Mary Dalton in the newsreel. As Jonathan Elmer notes, "if there is a link between the masturbation and the subsequent newsreel, it is only Wright and the reader who sees it. A logic might appear to link them, but that logic is not present as motivation for Bigger and Jack." ${ }^{13}$ Strikingly, however, in the manuscript version the district attorney assumes exactly such a motivating logic for Mary's murder. “"Though Jack Harding would not admit it outright,"” the prosecutor proclaims, “we got 
The picture had not yet started and they sat listening to the pipe organ playing low and soft. Bigger moved restlessly and his breath quickened; he looked round in the shadows to see if any attendant was near, then slouched far down in his seat. $\mathrm{He}$ glanced at Jack and saw that Jack was watching him out of the corners of his eyes. They both laughed.

"You at it again?" Jack asked.

"I’m polishing my nightstick," Bigger said.

They giggled.

"I'll beat you," Jack said.

"Go to hell."

The organ played for a long moment on a single note, then died away.

...

He looked at Trader Horn unfold and saw pictures of naked black men and women whirling in wild dances and heard drums beating and then gradually the African scene changed and was replaced by images in his own mind of white men and women dressed in black and white clothes, laughing, talking, drinking and dancing. ....

He frowned in the darkened movie, hearing the roll of tom-toms and the screams of black men and women dancing free and wild, men and women who were adjusted to their soil and at home in their world, secure from fear and hysteria (29-30, $33,34)$.
The picture had not started and he slouched far down in a seat and listened to the pipe organ shudder in waves of nostalgic tone, like a voice humming hauntingly within him. He moved restlessly, looking round as though expecting to see someone sneaking upon him. The organ sang forth full, then dropped almost to silence.

"You reckon we'll do all right at Blum's," he asked in a drawling voice tinged with uneasiness.

"Aw, sure," Jack said; but his voice, too, was uneasy.

....

There was a short newsreel which Bigger watched without much interest. Then came The Gay Woman in which, amid scenes of cocktail drinking, dancing, golfing, swimming, and spinning roulette wheels, a rich young white woman kept clandestine appointments with her lover while her millionaire husband was busy in the offices of a vast paper mill. Several times Bigger nudged Jack in the elbow as the giddy young woman duped her husband and kept from him the knowledge of what she was doing (490, 491). 
enough information out of him to know that when the shadow of Mary Dalton was moving upon the screen those boys indulged in such an act! It was then that the idea of rape, murder, and ransom entered the mind of this moron! There is your motive and the vile circumstances under which it was conceived!"' (410; original emphasis). In the 1940 edition, this reference changes to read simply, "After seeing a movie that Saturday morning ..." (343), interestingly retaining a ghostly reference to that line's unpublished predecessor.

These revisions thus also remove, I would suggest, the novel's embedded opportunity for a Lacanian misrecognition of Bigger as a racialized, sexualized figure. Certainly the Book Club Native Son still enables its audience to read against the grain of the prosecutor's speech, if only because those readers know there has been no rape, and no murder as such. But by including at this early point in the narrative a masturbation scene that many white readers would likely find "a bit on the raw side," the original Native Son also enables its white middlebrow audience to misread Bigger along loosely the same lines as the DA: if there is no specific object of Bigger's masturbation, that is, it becomes disconnected from yet adjacent to the cinematic images of Mary Dalton, suggesting a subtextual link that Wright implants according to the terms of such readers' social predispositions. "If we want to spare ourselves the painful roundabout route through the misrecognition," Slavoj Žižek writes, "we miss the Truth itself: only the 'working-through' of the misrecognition allows us to accede to the true nature of the other and at the same time to overcome our own deficiency." ${ }^{14}$ In this way the manuscript version of Native Son opens itself to such a "working-through" in ways that the Book Club version cannot, if we recognize "our own deficiency" in juxtaposing the masturbation and newsreel scenes. ${ }^{15}$

In the "Restored" novel, the logic that "might appear to link" these scenes is of course cultural, and explains why the Book Club judges sought not only the removal of the masturbation scene but the newsreel episode as well, in addition to corresponding depictions of Mary's sexual behavior and desires. As Abdul R. JanMohamed notes, this scene as a whole "publicly stages one of the fundamental circuits of identificatory exchange offered by a racialized capitalist society, a circuit that holds up the rich white woman as the ultimate object of sexual and material desire for everyone-except the racialized male subject, for whom this woman is deployed, like the object of the traditional oedipal relationship, as at once the object of ultimate desire and the object of the ultimate prohibition." ${ }^{16}$ The image of Mary Dalton in the newsreel provokes exactly such 
a reaction from Jack, who tells Bigger, “Ah, them rich white women'll go to bed with anybody, from a poodle on up. They even have their chauffeurs"' (33), just after Bigger has told Jack that he could visit Florida, but he would "be hanging from a tree like a bunch of bananas"' (32). The revised version of this scene deletes both these remarks, shifting straight from a summary of The Gay Woman to the second feature, Trader Horn, but now substantially altering Bigger's reaction to the images of Africa in that film. That paragraph begins, in both versions, "They laughed. Bigger turned his eyes to the screen, but he did not look" (33), but this laughter shifts its antecedent, from Jack's joke, "punching Bigger in the ribs, 'if you run across something too much for you to handle at that place, let me know" (33), to the innocuous exchange, "Shucks. I got a great mind to take that job,' Bigger said. 'Sure. You don't know what you might see"' (493). Thus when Bigger perceives the African characters in Trader Horn as, unlike himself, "men and women who were adjusted to their soil and at home in their world, secure from fear and hysteria" (34), the terms of that perception transition from a juxtaposition highlighting the impossibility of Bigger's sexualized, racialized subjectivity to a discussion of the Gay Woman plot that hinges largely on Bigger and Jack's perceptions of class difference. When Bigger in the Book Club edition, "full of a sense of a life he had never seen," asks Jack, "You reckon folks really act like that?" Jack's response is simply, "Sure, man. They rich"' (493). Viewed simply as "rich," the characters in The Gay Woman do not generate the same kinds of racial-sexual tensions as the image of Mary Dalton in the newsreel, leading to the necessary changes to her characterization as the narrative proceeds, and indicating once more that Wright "would not have been allowed to publish, at that historical moment, an actual consummation of cross-racial sexual desire." ${ }^{17}$

In this respect, Wright's revisions, to this scene and more broadly, tend to hollow out Bigger's subjectivity, in a shift that is largely in keeping with the narrative as a whole. One of the novel's most striking narrative effects is the insistent focus on a central character's actions and thoughts, while maintaining a comparatively undeveloped consciousness within that guiding perspective. Native Son is structured like a Bildungsroman - a protagonist struggles with society and follows a downward journey toward an expected arrival into psychological maturity, even if the narrative always withholds this conclusion-in keeping with its larger aim of "chronicl[ing] the tragic outcomes to be found in a system of oppression." ${ }^{18}$ At the same time that Bigger lacks the kind of intricate inner life that defines Ulysses or Mrs. Dalloway or the Yoknapatawpha saga, the 
novel allows readers no other perspective from which to view his story; as Wright explains in "How 'Bigger' Was Born," he sought throughout "to 'enclose' the reader's mind in a new world, to blot out all reality except that which I was giving him" (459). ${ }^{19}$

This central narrative tension derives from the historical and cultural distinction between what the philosopher Charles Mills terms "persons" and "subpersons." "Person," Mills explains, "is really a technical term, a term of art, referring to a status whose attainment requires more than simple humanity," while subpersons "are humanoid entities who, because of deficiencies linked with race, lack the moral status requisite for enjoyment of the bundle of rights and freedoms appropriate for persons." ${ }^{20}$ Mills mobilizes this distinction to explain the contradiction between the modern privileging of an individual right to liberty and the vast networks of slavery and colonialism proceeding simultaneously, and indeed often embodied in such apparent paradoxes as Thomas Jefferson's failure to free his slaves, John Locke's shares in a slave-trading company, or Immanuel Kant's interest in racist anthropology. Such contradictions only appear so, Mills contends, because historical reframings of egalitarianism elide the ways in which "entire categories of humans [were] systematically seen by the theory as less than persons" (217).

Native Son's modernist "crisis of representation," then, derives from the location of a subperson in the central narrative position. When I presented an earlier version of this essay at an MLA session titled "Popular Modernism," one of the first audience responses disputed Native Son's status as a modernist novel at all. This is true if we understand modernism only as a cultural movement producing what Astradur Eysteinsson influentially analyzes as "site[s] of troubled signification" (and indeed, Eysteinsson even cites a reference to Native Son as indicative of modernism becoming "an indistinct period term"). ${ }^{21}$ But the different (though no less modernist) crisis of representation that I see in Wright's novel derives precisely from its refusal to employ high modernism's hallmark narrative techniques. Because Bigger cannot become a modern person, in Mills's terms, his position at the narrative center of Native Son exposes the ideological hollowness of what Simon Gikandi calls Kant's "idealistic claim that it is in the universal realm of art and aesthetic judgment that we come to a sense of ourselves as free, self-reflective subjects."22 Wright's white Book Club readers, especially, are compelled to read through a subject who seems neither free nor self-reflective. This may result, historically, in readings that reinforce cultural distinctions between the cat- 
egories of "Negro" and "American" even while claiming to collapse such boundaries, as in one review's claim, cited in a Harper advertisement, that "Wright is not only the best Negro writer but an American author as distinctive as any now writing."

At the same time, the gap between the novel's focalization through Bigger and the narrator's periodic references to ideas Bigger himself cannot articulate highlights the aesthetic and epistemological fissures between Bigger's representation in the novel and the philosophical history from which the possibilities-and impossibilities-of that representation descend. Wright's narrative mobilizes "thick racialism" at the level of character, only to subvert this ideological attitude at the level of form: because of the divide between Bigger as character and the narrative voice/Wright as implied author, Native Son effectively invites its readers-especially, I would suggest, its Book Club subscribers-to view Bigger Thomas as precisely the kind of intellectually and morally vacant black subject they would expect. From the novel's beginning, the consistent perspectival focus on Bigger is in tension with a narratorial reporting on a different rhetorical and psychological register. At the conclusion of the opening scene, for example, the narration shifts from direct descriptions of Bigger's actions and thoughts to a broader sense of his social and emotional condition.

He shut their voices out of his mind. He hated his family because he knew that they were suffering and that he was powerless to help them. He knew that the moment he allowed himself to feel to its fullness how they lived, the shame and misery of their lives, he would be swept out of himself with fear and despair. So he held toward them an attitude of iron reserve; he lived with them, but behind a wall, a curtain. (10)

Certainly Bigger is aware of these feelings, even if they would exceed his own linguistic capacity; while the repetitive sentence structure echoes Bigger's mode of perception, their content reframes his feelings within more complex social terms. Similarly, the narrator reports while Bigger is in prison: "Though he could not have put it into words, he felt that not only had they resolved to put him to death, but that they were determined to make his death mean more than a mere punishment; that they regarded him as a figment of that black world which they feared and were anxious to keep under control" (276). Such reminders of the gap between readers' access to the narrator's reports of Bigger and Big- 
ger's actual subjectivity position readers as always unable to identify fully with Bigger, compelling, especially, Wright's white audience to reflect on the terms of and cultural reasons for that narrative impossibility. In this sense, the novel's publication through the Book-of-the-Month Club, while premised on revisions that reinforce standard social definitions of racial identity in 1940, also heightens the self-conscious tensions that derive from reading a narrative without a regulating white point of entry (except, as I will note below, for the paratextual guarantee of readerly safety granted by Fisher's introduction).

At this point it may be worth noting the historical power of the Bookof-the-Month Club in the 1930s and 1940s, in order to think a bit more precisely about the readers who were consuming this text. As Beth Luey points out in her history of twentieth-century American publishing, the 1930 s began with fewer than 800 bookstores across the nation, while the Book Club could boast more than 100,000 members at the same time. Thus, the "club did not merely distribute books but publicized and promoted them. . . . Rather than competing with booksellers, as retailers feared, the book clubs increased sales for everyone."23 By 1940, club membership had reached 500,000, yielding sales of 200,000 copies for Native Son just in its first three weeks on the market. ${ }^{24}$ As further evidence of the Book Club's commercial power, consider that only about 60,000 more copies of the novel had sold by 1943, despite its reissue in cheaper editions by the Modern Library and Grosset \& Dunlap, which together amounted to about 40,000 sales. As Aswell observes in a 1943 letter, "This fact in itself is something of a phenomenon in book publishing." ${ }^{25}$ While Henry Canby and other Book Club judges were therefore in the position of cultural arbiter for their readers, they perceived this role in generally pragmatic terms, as Janice Radway demonstrates. "In their minds the value of a book was not fixed once and for all at the moment of its creation," Radway writes, "but was established and reestablished anew in the process of exchange every time it made its way into the hands of readers who found particular uses for it in keeping with their own peculiar aims."26

Such pragmatist rhetoric swirls through Canby's review of the novel for the Book Club newsletter, which Harper reprinted in full across both the inside and the back jackets. "Bigger-and we all know Bigger-is no persecuted black saint," Canby advises. This ubiquitous quality allows Native Son to reach across racial boundaries in its readers for Canby: "And no white man-and, I suspect, few Negroes-will finish this nar- 
rative without an enlargement of imagination toward the psychological problems of the Negroes in our society-and an appreciable extension of sympathy." In Canby's review, Native Son oscillates between the two roles most often assigned to African American literature until at least the Black Arts Movement.

Let me turn to a specific example, Harper's initial ad for Native Son. Quoting from the conclusion of Canby's review, the ad declares, "This powerful and sensational book is certainly the finest novel as yet written by an American Negro.... It is no tract or defense plea. Like The Grapes of Wrath, it is a fully realized story of unfortunates, uncompromisingly realistic, and yet quite as human as it is Negro. To the growing list of artistic achievement of a high quality by a race which is, perhaps, singularly gifted in art, NATIVE SON must surely be added, with a star for notable success." ${ }^{27}$ Beyond the self-evident ways in which the last sentence, especially, assumes "the Negro" to be an essential, material category, not "something so purely social, something made in the United States" as Wright would later put it, Canby's review and its central position in Harper's ad implicitly distinguishes between the cultural categories of "human" and "Negro" in its claim that Native Son rather surprisingly manages to be both. ${ }^{28}$

In this respect the novel as textual property-to be produced, marketed, and distributed in ways that largely confirm the prevailing racial imagery of 1940 even as these are challenged by the novel's publication itself-reinforces the property values that Cheryl Harris has associated with whiteness. ${ }^{29}$ The ad's rhetoric constructs a set of readerly assumptions around Native Son-that it is a story above all, not a politicized "tract or defense plea," that it indeed represents "artistic achievement" that manifest themselves as well in an often advertised blurb from Time highlighting the narrative's "murder-mystery suspense." The book's original jacket continues this dynamic: while the cover consists simply of title and author's name, with a picture of Bigger standing outside his apartment building, an overflowing trash can juxtaposed on the other side of the stairs, book buyers (or browsers) turning to the inside jacket find Canby's Book Club newsletter review, extending across both inside flaps to the bulk of the back jacket as well, followed by a brief blurb from the Atlantic Monthly editor, and finally a note on the author.

Richard Wright was born on a plantation in Mississippi, the son of a mill worker and country school teacher. With his family con- 
tinually on the move, his education and upbringing were erratic. At fifteen he left home, bumming his way all over the country, working at any kind of job from ditch-digging to clerking in a post-office, and always reading everything that fell into his hands. Eventually he became head of the Harlem branch of a New York newspaper. His first book, Uncle Tom's Children, won first prize in a national contest held by Story. Later, the Guggenheim Committee read Native Son and awarded him a Fellowship.

The implied question this biographical sketch answers- how could a "Negro" come to write such an apparently important novel-simultaneously markets Wright as a typically American rags-to-riches figure while carefully emphasizing the Southern poverty of his background. Turning back to the book itself, Wright's 1940 readers find an introduction by Dorothy Canfield Fisher, a prominent author and Book Club judge, in which she declares that "the author shows genuine literary skill in the construction of his novel." ${ }^{30}$ While Fisher finds Native Son "comparable only to Dostoievski's revelation of human misery in wrong-doing," she immediately assures her readers (who were, after all, not yet Wright's), "I do not at all mean to imply that Native Son as literature is comparable to the masterpieces of Dostoievski" (x). As several critics have observed, Fisher's introduction functions as "a latter-day example of the process of white authentification" produced by white "editors" introducing slave narratives. ${ }^{31}$ Similarly, Barbara Johnson concludes, "It is not surprising that the first edition of Native Son should have been preceded by an introduction by Dorothy Canfield Fisher. The envelope of Wright's letter had to be made to say "The white woman is safe."'32 Coupled with the various revisions made at the behest of the Book Club, the juxtaposition between the novel's narratorial and ethical effects and its marketing through advertisements and white-authored paratexts speaks to the terms of possible publication in the 1940s United States. Just as the play between the manuscript and published movie scenes presents Wright's original and later readers with the cultural logic undergirding racialist aesthetics as well as the means of its own undoing, the work as a whole, both in its narrative and bibliographical dimensions, signifies upon the enabling conditions of a mainstream work of African American fiction in the late modernist period.

This reading should not downplay the novel's immense historical significance, whether considered through James Baldwin's famous critique 
in "Notes of a Native Son" or simply measured through Native Son's enduring presence as one of the foundational works of twentieth-century African American literature. While the novel's published version certainly did not prevent it from resonating so powerfully with its initial African American readers, it is worth imagining the contingencies of a counterhistory in which Native Son could appear publicly in its manuscript form. With the "restored version" available to contemporary readers, we can perceive another fold in the text's production saga, by reading both texts with and against each other.

\section{II. "American Ideals" and American Hunger: Shaping Black Boy}

A similar dynamic plays out for the publication of Black Boy as a Book Club selection, in this case resulting famously in the deletion of the manuscript's second half, detailing Wright's life in Chicago following his escape from the South, and the subsequent rewriting of what then became the book's closing paragraphs. Rather than submit to a lengthy process of revision and more revision, filtered through letters from Dorothy Canfield Fisher on behalf of the Book Club, Wright at this point in his career could conceivably have sacrificed the club's virtual guarantee of greater sales and stood his aesthetic ground: promoted as "By the author of $\mathrm{Na}$ tive Son," Black Boy would very likely have remained a market sensation, if probably ascending to lesser commercial heights than with the Book Club imprimatur. The changes to Black Boy are more radical than those in Native Son, as they transform Wright's ending into a hopeful, because ambiguous, look to the potential of Chicago and the North, allowing readers to assume a comparatively easy journey to Wright's becoming the author of Native Son (events which are left unnarrated in Wright's manuscript as well, but whose difficulty is clearly gestured toward in the ultimately bleak portrayal of segregated Chicago life, even among the Communist Party). Black Boy is largely a narrative of a subperson's construction by the racist environment surrounding him, though in this case that character, unlike Bigger, is infused throughout with the mental life, and thus "moral status," of a "person" in Mills's terms. Black Boy's crisis of representation is thus more overt, but its textual history also reveals the material tensions informing the production of such a narrative in the midcentury United States, as the commercial and political need for nar- 
rative openness transfers the narrow range of representable sexualities in Native Son into a broader insistence on the implicitly white North as a zone of social possibility.

The apparent irony of Wright's more extensive revisions, despite his much more established commercial status, can again be explained in part through his correspondence with Aswell and Reynolds. In between Native Son and Black Boy, Wright had seen his novel transformed into a Broadway play, completed 12 Million Black Voices, worked extensively on two full drafts of what would have been his second novel, Black Hope, and, after setting that project aside, begun plans for a different novel, The Jackal. Never completed, Black Hope would have been Wright's only novel with a female protagonist, Maud Hampton, a light-skinned young woman in New York. ${ }^{33}$ Wright's struggles with this project were not sufficient to endanger its planned publication, but, unknown to him, Aswell and the Harper marketing executives were concerned. As Aswell noted in a 1942 memo: "Give it a page and list it simply as the new novel by Richard Wright, instead of the usual description. Say little or nothing about this book, but emphasize that this is Wright's first novel since $\mathrm{Na}$ tive Son, which he has been working on for more than two years" (Harper Bros. Papers). Similarly, Reynolds warned his client that the direction of his novelistic career could well turn on the success of Black Hope, writing in April 1942:

If it has a large sale you have a fair chance of being somewhat a fixed star in the publishing firmament. Your books will vary in sales but they should hold up among the class of large sellers say the way a man like Steinbeck does, or A.J. Cronin. If BLACK HOPE doesn't sell, you will remain the author of NATIVE SON and the trade and the book stores and everybody will think of you in that way. (Rowley, 265)

While the production process for Black Boy echoes and expands upon the revisions required for Native Son, Wright's more reluctant acquiescence to the Book Club's changes may well have been overcome by a different motivation for commercial success, namely, to become something more than "the author of NATIVE SON" in the minds of publishers and booksellers. Furthermore, Reynolds at this time represented both Wright and Fisher, and had profited handsomely from his more established client, selling the serial rights to her 1933 novel Bonfire for $\$ 30,000$ for example, despite the economic climate of the Great Depression. ${ }^{34}$ At 
least the opportunity for a conflict of interest arises when considering Reynolds's role as mutual agent.

As with Native Son, Wright initially revised a scene involving a black phallus, this time at Aswell's behest even before the proofs had been sent to the Book Club. Whereas the masturbation scene in Native Son functions on at least one level as Bigger and Jack's response to their symbolic castration, the Black Boy scene enacts precisely that mode of social oppression. While the young Richard is working for the optical instruments company in Memphis, his white associate Reynolds approaches, as part of an ongoing pattern of harassment.

Original version

"Richard, how long is your thing," he asked me.

"What thing?" I asked.

"You know what I mean," he said. "The thing the bull uses on the cow."

I turned away from him; I had heard that whites regarded Negroes as animals in sex matters and his words made me angry.

"I heard that a nigger can stick his prick in the ground and spin around on it like a top," he said, chuckling. "I'd like to see you do that. I'd give you a dime, if you did it" (188).
Revised version

"Nigger, you think you'll ever amount to anything?" he asked in a slow, sadistic voice.

"I don't know, sir," I answered, turning my head away.

"What do niggers think about?" he asked.

"I don't know, sir," I said, my head still averted.

"If I was a nigger, I'd kill myself," he said.

I said nothing. I was angry.

"You don't know why?" he asked.

I still said nothing.

"But I don't reckon niggers mind being niggers," he said suddenly and laughed (412).

Strikingly, the revised passage replaces a spectatorial obsession with the violent fantasy of shameful death; clearly, both interactions are motivated by the white man's simultaneous fascination and horror entailed by imagining himself as black, projecting first a phenomenological and then epistemological divide between himself and Richard, both of which stand in for the cultural (il)logic of racial identity. Wright's shift, from the African American man as object of physical to mental curiosity interestingly parallels Black Boy's broader readerly effect, as the physical presence maintained by Bigger transitions into a prolonged description of what Richard "think[s] about." 
Such an emphasis on physical presence manifests itself in the autobiography's title as well, though at this stage the manuscript was still called American Hunger. This had replaced the original Black Hunger, with Southern Night and The First Chapter floated as possibilities (the latter suggested by the Book Club) before Wright settled on Black Boy in August $1944 \cdot{ }^{35}$ Once Wright had agreed to cut the book's Chicago section, a new title became necessary as well; as he explained to Aswell, "Now, this is not very original, but I think it covers the book. It is honest. Straight. And many people say it to themselves when they see a Negro" (Rowley, 290). As Wright's frustrated tone suggests, the process of securing the Book Club's approval for Black Boy was much more complicated than for Native Son, with extensive negotiations among Wright, Reynolds, Aswell, and Fisher, on behalf of the other judges. Beyond the change in the narrative's destination, the composition and revision of a new closing section generated a series of correspondence between Wright and Fisher, with the elder woman gently insisting on a more forgiving attitude toward Northern white society. This despite the fact that Fisher herself had recently refused to accommodate her own work to the political tastes of an editor, determining not to change her portrayal of an anti-Semitic private school in her 1939 novel Seasoned Timber for serialization in Woman's Home Companion. ${ }^{36}$

Originally, "Southern Night," as the first section of American Hunger, related Wright's secret departure from Memphis to Chicago and had a simple conclusion.

I stepped from the elevator into the street, half expecting someone to call me back and tell me that it was all a dream, that I was not leaving.

This was the culture from which I sprang. This was the terror from which I fled. (257)

With the Chicago section of the narrative, "The Horror and The Glory," now absent as the counterpoint to this conclusion, Wright set about revising the ending for Chapter XIV, and the book as a whole, in response to the suggestion relayed to Aswell of another Book Club judge, Clifton Fadiman, "that he summarize briefly, and make explicit, the meaning that is now implicit in the preceding pages" (Harper Bros. Papers). The content, and especially the tone, of this new conclusion went through multiple revisions over two months, from late May to late July 1944, with 
letters and telegrams triangulated among Fisher, Aswell, and Wright. Couched in a rhetoric of almost grandmotherly advice-born in 1879, Fisher was nearly thirty years Wright's elder, at one point praising the "reasonableness and ingenuity from a man young enough (I assume) to be my grandson!" (Madigan, Keeping Fires, 239)—Fisher's correspondence insists on a softening of Wright's self-reliant attitude toward Northern white understanding.

Their exchanges circle around a series of questions Wright asks about this stage in his life: "What was it that made me conscious of possibilities? From where in this southern darkness had I caught a sense of freedom?" ${ }^{37}$ From the start, Wright answered in terms of his early reading"It had been only through books," the following paragraph begins (413) -but Fisher sought a more developed sense of that reading, particularly in regard to its Americanness. "I gather that you cannot bring yourself to use, even once, the word 'American' in speaking of 'the tinge of warmth which came from an unseen light," she asks in a July 12 letter, continuing, "However dimly that light came to you, suffering so acutely from the rough denial of the very existence of American ideals, part of it must have come through American delineation of American characters" (Madigan, Keeping Fires, 234, 235). In response, Wright added and revised two paragraphs, acknowledging, "It had been my accidental reading of fiction and literary criticism that had evoked in me vague glimpses of life's possibilities," and citing in Theodore Dreiser, Edgar Lee Masters, H. L. Mencken, Sherwood Anderson, and Sinclair Lewis a sense of being "defensively critical of the straitened American environment," and thus a feeling "that America could be shaped nearer to the hearts of those who lived in it" (Black Boy, 413). As Rowley notes, these references would serve "not at all as the glowing epithets that Canfield intended" (289). Wright's frustrations with this process are clear in his letters to Aswell, declaring a week after the Fisher letter cited above, "I really feel that this ought to do the thing" (quoted in Rowley, 289). Wright takes on a more conciliatory tone in his letters to Fisher herself, and Aswell remains solicitous of her approval throughout, writing initially, "Mr. Wright's first problem is to satisfy you and I don't know whether he has succeeded. Needless to say, I hope he has" (Harper Bros. Papers). By July 24, Aswell sent Fisher a telegram seeking her final approval: "PLEASE WIRE COLLECT WHETHER RICHARD WRIGHT'S NEW CONCLUSION MAILED YOU FRIDAY IS SATISFACTORY. I THINK IT EXCELLENT BUT AM DELAYING SETTING IT PENDING YOUR APPROVAL," 
prompting her reply on the same day, "I WROTE RICHARD WRIGHT YESTERDAY MY COMPLETE APPROVAL OF HIS ENDING IN PRESENT FORM" (Harper Bros. Papers). The question of the title was finally resolved a month later, but publication was delayed until February 1945, as the Book Club deliberated about which month to announce its official selection.

As with Native Son, Fisher's paratextual comments inform the terms of Black Boy's reception, through her review in the Book Club newsletter and a blurb requested by Aswell, appealing to Fisher as "Richard Wright's original sponsor," which was eventually published with the main text and labeled an "introductory note" (Harper Bros. Papers). As Aswell explained in a June letter, "Instead of putting it on the jacket, I should like to insert it as an introductory note in the book itself, thus making it a permanent part of the book" (Harper Bros. Papers). Reynolds, in one of his few departures from Aswell's preferences in such matters, objected to this placement, sensing the more contingent status of the jacket blurb as a subtle way to disengage Wright from Fisher's shadow. "While I think this comment by Dorothy Canfield Fisher is grand and certainly ought to be used in any way possible," Reynolds wrote, "I personally would rather see it used on the jacket than in the body of the book. Richard Wright seems to me so well known now that he doesn't need any puff or possibly implied apology in the body of his book and to announce the book as with an introduction by Dorothy Canfield Fisher seems to me almost to be scattering your shots" (Harper Bros. Papers).

Fisher's note does indeed read as an "implied apology."

More than eighty-five years ago, Oliver Wendell Holmes nobly said, "It is so much easier to consign a soul to perdition or to say prayers to save it, than to take the blame on ourselves for letting it grow up in neglect and run to ruin. The English law began, only in the late eighteenth century, to get hold of the idea that crime is not necessarily a sin. The limitations of human responsibility have never been properly studied."

If Dr. Holmes were alive now, he would be proud as I am proud, of the chance to help bring to the thoughtful attention of intelligent, morally responsible Americans, the honest, dreadful, heart-breaking story of a Negro childhood and youth, as set down by that rarely gifted American author, Richard Wright. (Harper Bros. Papers) 
At the time of his death in 1935, Holmes was the longest-serving jurist in the history of the Supreme Court, but his citation here, along with Fisher's analogical elevation to an equivalent level of pride, combine to displace Wright himself from the central focus of these paragraphs, an effect heightened by the note's placement as a "permanent part of the book" and its advertisement on the jacket as well. While Fisher's introduction to Native Son announces the safety of the novel for white readers, her note for Black Boy oscillates between Holmes's insight as a criticism of white society and Fisher's repositioning of Wright's memoir away from such political indictments and toward an individual "honest, dreadful, heart-breaking" testimonial.

This tension, between autobiography as a narrowly focused narrative or as a metaphorical expression of larger social concerns, surely motivates the most surprising feature of American Hunger/Black Boy, Wright's decision to end the story well before the event for which he was already most familiar to his audience, the composition of Native Son. ${ }^{38}$ Such a readerly desire appears in a photo essay in the June 4,1945 , issue of Life, with actors recreating various scenes from Black Boy. The final image, of the boxing match between Richard and Harrison, carries the legend: "Black Boy ends as Wright, 18, leaves the South. Wright plans to complete his autobiography and tell what happened to him after he went north. That story would include early jobs in Chicago as porter and ditchdigger, work on the Federal Writers Project, how he joined the Communist Party and left it, and how he married a white woman, settled in Brooklyn, wrote his best-selling Native Son" (Richard Wright Papers). There is no evidence that Wright had such plans, of course, beyond publishing the Chicago sections of his original manuscript, which Aswell promised Harper would do in "some future book" (Rowley, 287). But to carry his story beyond that point, into marriage, life in Brooklyn, and the writing of Native Son, clearly lies outside of Wright's conception of his autobiography, even as this deliberate omission plays on the popular desire for such a story. The major problem with this autobiographical conclusion is presumably its ability to undercut the political force of the preceding narrative, especially in its manuscript form: as the renowned and wealthy author of Native Son, Wright becomes the kind of exception to the rule that can be misread as undercutting a broader critique of racialized social structures.

Juxtaposing the original and Book-of-the-Month Club versions of American Hunger/Black Boy, then, demonstrates the much broader ef- 
fect of the changes between manuscript and print in this case. Whereas the revisions to Native Son radiate out from altered local details to more global representations of race and sexuality, the omission of "The Horror and the Glory," along with the revised Chapter XIV, alter the shape of the narrative itself, with ripples extending back across the remaining autobiographical structure. The successful, or even redemptive, story of $\mathrm{Na}$ tive Son's production (however ironized that story becomes in contrast to the actual history of the text's transformation into its Book Club state) indirectly influences readers' approaches to the conclusion of American Hunger or Black Boy, though in the case of the original manuscript, that journey is much more fraught, given Wright's fragile desire "to try to build a bridge of words between me and that world outside, that world which was so distant and elusive that it seemed unreal" (384). By purposefully leaving the construction of that bridge as an unrepresented event in an unnarrated future, American Hunger only gestures toward that process, with its final image of Wright holding pencil over paper and waiting "until I knew what to say" (383). The closing lines that Wright negotiated with Fisher, on the other hand- "With ever watchful eyes and bearing scars, visible and invisible, I headed North, full of a hazy notion that life could be lived with dignity, that the personalities of others should not be violated, that men should be able to confront men without fear or shame, that if men were lucky in their living on earth they might win some redeeming meaning for their having struggled and suffered here beneath the stars" (415)-offer a much grander and more abstract vision of an almost celestial "North" into which Wright ascends. Authorial agency shifts in this passage from Wright alone, awaiting knowledge and inspiration, to an anonymous figure among the men poised on the brink of their "redeeming meaning."

In fact, neither of these narratives accurately represents the production of Native Son. From the conversations and newspaper clippings Margaret Walker provided about the Robert Nixon murder case in Chicago, to Jane Newton's "endless discussions" about the novel in progress while Wright lived at the Newtons' house in Brooklyn, to the "'positively public way" Newton remembers the novel being composed (Rowley, 155, 156), it is clear that Native Son, like virtually every text, went through an inherently social process of composition and revision, long before the galleys arrived at the desks of the Book-of-the-Month Club judges. To imagine "private" or "public" versions of Native Son or Black Boy, any more than "right" or "wrong" editions, misreads the historical networks through 
which texts make their way to the literary marketplace. In "Blueprint for Negro Writing," Wright navigates between African American writers' ostensibly exclusive choices of authorial authenticity or compromise. "Are they being called upon to 'preach'?" Wright asks. "To be 'salesmen'? To 'prostitute' their art? What is the relationship between 'something to believe in' and artistic expression?" (48). Wright's way out of this dilemma is to rely on "perspective": "the frame in which the picture is hung," or "that part of a poem, novel, or play which writers never put directly upon paper, but which is sensed in every line of the work" (49). That immaterial sense of the work, grounded in the material production of various versions in documents, expresses as well the most illuminating perspective from which to read the fluid texts of Native Son and Black Boy, and the "double vision" necessary to perceive the social processes of African American textual production. ${ }^{39}$

\section{Notes}

I am grateful for the Bibliographical Society of America's 2010 Mercantile Library Fellowship in North American Bibliography fellowship, which enabled my archival research at Princeton's Firestone Library and Yale's Beinecke Library.

1. Native Son and Black Boy are the most dramatic examples of a publishing trend that continued for much of Wright's career, from Harper's original rejection of "Bright and Morning Star" in Uncle Tom's Children to the "drastic cutting" of the manuscript for The Outsider, which Paul Gilroy aptly terms "a book that was uncomfortable with its editor's attempts to turn it into a murder mystery" (The Black Atlantic: Modernity and Double Consciousness [Cambridge: Harvard University Press, 1993], 171). By that point Wright's original editor at Harper had left, and he was working with John Fischer, who, as the author of an "impassioned piece of Cold War propaganda," was less sympathetic than Edward Aswell to Wright's politics (Hazel Rowley, Richard Wright: The Life and Times [Chicago: University of Chicago Press, 2001], 355). The "drastic cutting" reference appears in a letter from Fischer to Wright and is quoted in Rowley, 405. Subsequent references to her biography will be made parenthetically.

2. James Weldon Johnson, "The Dilemma of the Negro Author," in The Politics and Aesthetics of the "New Negro" Literature, ed. Cary D. Wintz (New York: Garland, 1996), 267.

3. John Bryant, The Fluid Text: A Theory of Revision and Editing for Book and Screen (Ann Arbor: University of Michigan Press, 2002), 60.

4. Peter Shillingsburg, "How Literary Works Exist: Implied, Represented, and Interpreted," in Text and Genre in Reconstruction: Effects of Digitalization on Ideas, Behaviours, Products and Institutions, ed. Willard McCarty (Cambridge: Open Book Publishers, 2010), 172.

5. Paul Taylor, "Malcolm's Conk and Danto's Color; or, Four Logical Petitions 
Concerning Race, Beauty, and Aesthetics," in African American Literary Theory: A Reader, ed. Winston Napier (New York: New York University Press, 200o), 666.

6. Richard Wright, "Blueprint for Negro Writing," in Napier, African American Literary Theory, 53. Subsequent references to this essay will be made parenthetically.

7. Zora Neale Hurston, "What White Publishers Won't Print," Negro Digest 8 (1950): 86.

8. Quoted in Richard Wright, Native Son (New York: HarperCollins, 1998), 486. Subsequent references, made parenthetically, will be to this edition of the novel unless noted otherwise.

9. The British publisher Gollancz, which had "turned it down flatly" after reading the original manuscript, also accepted the revised version (quoted in Wright, Native Son, 486).

10. Richard Wright Papers, Yale Collection of American Literature, Beinecke Rare Book and Manuscript Library. Subsequent references will be noted in the text.

11. Rampersad notes that Trader Horn, which was nominated for an Oscar, "is about a woman who is kidnapped by an African 'tribe' who worship her as a white goddess" before her eventual departure (Richard Wright, Works, vol. 1 [New York: Library of America, 1991], 490). The immersion of the white woman in "native" African tribal culture here clearly refracts Mary Dalton's position in Bigger and Jack's jokes about wealthy white women and their black chauffeurs.

12. Aimé J. Ellis, “Boys in the Hood': Black Male Community in Richard Wright's Native Son," Callaloo 29 (2006): 194.

13. Jonathan Elmer, "Spectacle and Event in Native Son," American Literature 70 (1998): 780.

14. Slavoj Žižek, The Sublime Object of Ideology (London: Verso, 1989), 63.

15. For other readings of the manuscript and published versions, see Yoshinobu Hakutani, Richard Wright and Racial Discourse (Columbia: University of Missouri Press, 1996), 63-64, 82-83, and the comprehensive and insightful analysis of each text from the perspective of genetic editing in Claudine Raynaud, "Changing Texts: Censorship, 'Reality', and Fiction in Native Son," in Richard Wright: New Readings in the 21st Century, ed. Alice Mikal Craven and William E. Dow (New York: Palgrave Macmillan, 2011).

16. Abdul R. JanMohamed, The Death-Bound Subject: Richard Wright's Archaeology of Death (Durham: Duke University Press, 2005), 92.

17. JanMohamed, 113. On interesting differences between the depiction of Mary in the published novel and in the 1941 theatrical version, see Jerry W. Ward Jr., "Native Son: Six Versions Seeking Interpretation," in Approaches to Teaching Wright's Native Son, ed. James A. Miller (New York: Modern Language Association, 1997), 18-19.

18. Herman Beavers, "Vortical Blues: Turbulence, Disorder, and the Emplotment of Surplus Meaning in Native Son," in Richard Wright's Native Son, ed. Ana María Fraile (Amsterdam: Rodopi, 2007), 97, original emphasis.

19. On Native Son's narrative politics, see also Barbara Foley, “The Politics of Poetics: Ideology and Narrative Form in An American Tragedy and Native Son," in Narrative Poetics: Innovations, Limits, Challenges, ed. James Phelan (Columbus: Ohio State University Press, 1987); John M. Reilly, "Giving Bigger a Voice: The Politics of Narrative in Native Son," in New Essays on Native Son, ed. Keneth Kinnamon (Cambridge: Cam- 
bridge University Press, 1990); and Laura E. Tanner, "Uncovering the Magical Disguise of Language: The Narrative Presence in Richard Wright's Native Son," Texas Studies in Literature and Language 29 (1987): 412-31. On the novel as a form of Bildungsroman, see Heather Daerre Humann, "Genre in/and Wright's Native Son," in Richard Wright's Native Son, ed. Ana María Fraile (Amerstad: Rodopi, 2007). On Native Son's ethical implications for white readers, especially, see the debate between Martha Nussbaum and Charles Altieri, in Nussbaum's Poetic Justice: The Literary Imagination and Public Life (Boston: Beacon Books, 1995) and Altieri's "Lyrical Ethics and Literary Experience," in Mapping the Ethical Turn: A Reader in Ethics, Culture, and Literary Theory, ed. Todd F. Davis and Kenneth Womack (Charlottesville: University of Virginia Press, 2001).

20. Charles W. Mills, "Modernity, Persons, and Subpersons," in Race and the Foundations of Knowledge: Cultural Amnesia in the Academy, ed. Joseph Young and Jana Evans Braziel (Urbana: University of Illinois Press, 2006), 218. Subsequent references to this essay will be made parenthetically.

21. Astradur Eysteinsson, The Concept of Modernism (Ithaca: Cornell University Press, 1992), 47, 94.

22. Simon Gikandi, "Race and the Idea of the Aesthetic," Michigan Quarterly Review 40 (2001): 347 .

23. Beth Luey, "Modernity and Print III: The United States, 1890-1970," in A Companion to the History of the Book, ed. Simon Eliot and Jonathan Rose (London: Blackwell, 2007), 371.

24. Mark Madigan, "Richard Wright, Toni Morrison, and United States Book Clubs," Acta neophilologica 37 (2004): 6.

25. Selected Records of Harper \& Brothers, Box 33, Folder 16; Department of Rare Books and Special Collections, Princeton University Library, reprinted with permission. Subsequent references to these materials will be made parenthetically.

26. Janice Radway, "A Feeling for Books: The Book-of-the-Month Club, Literary Taste and Middle-Class Desire," in The Book History Reader, ed. David Finkelstein and Alistair McCleery (London: Routledge, 2002), 360.

27. As Dwight Garner notes, American publishers' advertisements did not begin attributing blurbs to specific reviewers until the 1930s. Read Me: A Century of Classic American Book Advertisements (New York: HarperCollins, 2009), 15.

28. Richard Wright, White Man, Listen! (New York: Doubleday, 1957), 119.

29. See Cheryl I. Harris, "Whiteness as Property," in Critical Race Theory: The Key Writings that Formed the Movement, ed. Kimberlé Crenshaw (New York: Norton, 1995).

30. Richard Wright, Native Son (New York: Harper \& Bros., 1940), xi. Subsequent references to this edition will be made parenthetically.

31. Keneth Kinnamon, "How Native Son Was Born," in Richard Wright: Critical Perspectives Past and Present, ed. Henry Louis Gates Jr. and K. A. Appiah (New York: Amistad, 1993), 123.

32. Barbara Johnson, "The Re(a)d and the Black," in Gates and Appiah, 152.

33. In both his earlier and later drafts, Wright focuses on the harsh conditions confronting black domestic servants in New York. In the original manuscripts, Maud is violently raped and imprisoned by Basin, a Southern criminal who transports her to 
New York for an unspecified role in an apparent prostitution ring there. This draft breaks off before completion. In the revised version, Maud passes in marriage, inheriting a fortune from her white husband, before ultimately killing herself and designating her black maid as her heir. Wright concludes in a synopsis prepared for reading the work in progress, "The ultimate purpose of the novel is to dramatize in terms of concrete action, the position of woman in modern society (this is not a novel with a 'feminist' theme!) and to reveal in a symbolic manner the potentially strategic position, socially and politically, which women occupy in the world today" (Richard Wright Papers).

34. Mark Madigan, ed., Keeping Fires Night and Day: Selected Letters of Dorothy Canfield Fisher (Columbia: University of Missouri Press, 1993), 347.

35. As evidence of the title's fluidity, an Aswell memo from late July 1944 lists eighteen possibilities in all, including The American Way, Black Hope (apparently recycled from the abandoned novel), Black Reality, Dark Awakening, and In a Strange Land (Harper Bros. Papers).

36. Madigan, Keeping Fires, 190-91. Fisher saw herself as a sympathetic and understanding reader of Wright's (and other African Americans') literature, concluding one letter: "I'm venturing to send you my last book (not a very picturesque or interesting one, although written with all my heart) because of a few pages in it, comparing the general attitude towards women to that towards Negroes. It's only an analogy, partial, but may be worth your looking at it" (Madigan, Keeping Fires, 237). That last book was Our Young Folks (New York: Harcourt Brace, 1943), which had grown out of Fisher's service on the American Youth Commission in the late 1930s and early 1940s. In a chapter titled "Equal Rights in Business," she investigates the role of women in the workplace, concluding, "It is almost startling to consider how closely the economic positions accorded to American women in the productive world parallels that of colored people. ... Women have, with no consent or will of theirs, been transplanted, like Negroes, from their old homeland where they were bosses of the useful work they did into a new world where, like colored people, they are regarded as useful servitors, never as bosses" (189-90).

37. Richard Wright, Black Boy (New York: Perennial Classics, 1998), 413. Subsequent references to this edition will be made parenthetically.

38. In a somewhat different vein, Janice Thaddeus in "The Metamorphosis of Black Boy" analyzes the manuscript and published versions of Wright's autobiography as "defined and open" (in Gates and Appiah, 272).

39. Wright, White Man, 78. 


\section{George Bornstein}

\section{THE COLORS OF MODERNISM}

Publishing African Americans, Jews, and Irish in the 1920 S

On 5 November 1939, shortly after the outbreak of World War II, Paul Robeson performed as lead baritone in the CBS radio performance of the eleven-minute cantata "Ballad for Americans," which caused the widest public reaction to a program since Orson Welles's sensational The War of the Worlds a year earlier. Unabashedly inclusionist in what the African American paper New York Amsterdam News called "white and colored voices, so mixed for the occasion," Robeson's strong baritone voice responded to the question "Am I an American?" with a resounding affirmation beginning "I'm just an Irish, Negro, Jewish ..." and went on to list a variety of ethnicities and religions. The song received a twentyminute standing ovation, with callers then jamming the CBS switchboard for two hours more. Its popularity cut across ethnic and political lines and led to performances at the nominating conventions in 1940 of both the Republican and the Communist parties, surely a unique occurrence. In giving African Americans, Jews, and Irish pride of place in a list that stressed common linkages more than very real tensions, Robeson was typical rather than exceptional, and particularly so for African Americans of the time. As late as 1965, the Black poet Melvin Tolson had the narrator of his masterpiece Harlem Gallery describe his ancestry as "Afroirishjewish" in a book published by Twayne, a Jewish firm founded by Jacob Steinberg in 1948. That volume carried an introduction by the Jewish poet Karl Shapiro championing Tolson as a great poet almost unknown because of his race and little represented in anthologies, a situation that Shapiro had experienced starting out as a Jewish writer in the 1930s. Indeed, Shapiro himself had already linked treatment of African Americans and Jews in poems like "University" with its famous beginning, "To hurt the Negro and avoid the Jew / Is the curriculum." My own recent book The Colors of Zion: Blacks, Jews, and Irish from 1845 
to 1945 aims to recover a range of lost connections among those three groups in a variety of areas (races, melting pots, nationalisms, popular culture, and especially the 1930s) and so to query our current categories of separation. ${ }^{1}$

Here I want to use "bibliographic codes" - the material features of the text, and particularly today those signifying particular publishers-to illuminate some of those lost linkages among minority groups, particularly African Americans, Jews, and Irish, and to refigure both their relation to what we used to call Anglo-American "modernism" and the nature of that "modernism" itself. I will argue that current editions of minority writers that obscure their original publishers also obscure the original social placement and reception of the texts, and that recovering those early bibliographic contexts exemplifies the relevance of book history and "social text" editing to literary interpretation. We often miss such possibilities either by neglecting publishers altogether or mistaking currently major firms for established ones a century ago. But back then publishers like Boni and Liveright, Knopf, Simon and Schuster, Viking, or Random House were new marginal upstarts largely unable to sign mainstream Anglo-Saxon writers. Instead, they succeeded by acquiring newcomers like themselves, particularly African American, Jewish, Irish, or other avant-garde modernist ones. Further, such firms were founded and largely staffed by Jewish editors who had bumped into glass ceilings at mainline houses and who created new networks in promoting work by different ethnic groups. ${ }^{2}$

Before 1890 American publishing centered on the Northeast, particularly Boston, with family firms like Houghton Mifflin and Little, Brown holding sway. By 1900 and especially with the outbreak of World War I, the publishing industry's center of gravity shifted to New York. Even so, old-line WASP houses continued to dominate and to publish primarily white, Anglo-Saxon Protestant authors. Literature by emerging groups, like that of Anglo-Saxon but avant-garde modernists or recent Europeans, usually had to seek out the newer, more marginal Jewish firms to reach a market at all. It took consistent pressure from William Dean Howells for the most famous Jewish writer of the previous generation, Abraham Cahan, to break through into publication in English, first with Yekl: A Tale of New York at Appleton and then with The Rise of David Levinsky at Harper.

Earlier, the editor of Harper's Weekly had returned the manuscript of Yekl by observing tartly, "The life of an East-Side Jew wouldn't interest an 
American reader." The editor's distinction between true Americans and members of ethnic or racial groups bedeviled minority authors before and since. Publishing historian Charles A. Madison observes that at the time "gentlemen publishers ... would not employ a Jew and made little or no effort to seek out Jewish writers." ${ }^{3}$ Alfred Harcourt of Harcourt, Brace-one of the few gentile publishers to promote ethnic literature, especially African Americans-captured the situation well in a retrospective look from 1937. Citing the "flood of European immigrants" to the United States beginning in the late nineteenth century, Harcourt observed, "While Boston publishers were bringing out sets of Longfellow and Emerson, in new bindings, new publishers sprang up in New York, notably Huebsch, Knopf, and Liveright, who began to publish translations of contemporary foreign authors and books by young American authors who had broken away from the Victorian point of view."4 If they weren't Irish, Black, or Jewish, those "young American authors" usually at least belonged to the avant-garde. Understanding their publishing networks creates new angles to see the literature of different groups as sharing in the larger modernist enterprise and, conversely, displays modernism as a more varied venture than earlier views often suggest. That means more than merely adding new authors and material, as important as that has been. Such addition also dictates what T. S. Eliot famously described in his essay "Tradition and the Individual Talent" (1919) as altering the whole previous ordering. It means rethinking both the works themselves and their interrelationships.

B. W. Huebsch, the son of a rabbi, could legitimately claim to be the first of the new publishers, beginning in the first decade of the twentieth century rather than the second or third as did the others. His small firm published an extraordinary number of valuable books, including work by European authors like Maxim Gorki's The Spy, Gerhardt Hauptmann's The Weavers, and August Rodin's Venus, and further afield even Mahatma Gandhi's Young India. Part of the Irish-inflected group that met at Petipas's restaurant in New York and featured John Butler Yeats (the poet's father) and Mary and Padraic Colum, Huebsch scored his greatest coup in becoming James Joyce's American publisher for his early works. That included the first American edition of the Dubliners stories as well as the first edition anywhere of Portrait of the Artist as a Young Man, both in 1916. He also published modernists like Sherwood Anderson and D. H. Lawrence. No wonder his contemporary Christopher Morley joked in the Saturday Review that "it used to be waggishly said that any Irish, 
Hindu, or German artist could find a home in Mr. Huebsch's list when no other publisher would take a chance on him."

Huebsch placed a high value on international cross-fertilization. Correlating a rise in European books with American imprints like his own with the wave of new immigration, he praised the "interchange of literatures and of the cultures they represent" in a way that anticipates conclusions of hybridity theorists of our own day like Cornel West and Anthony Appiah. West, for example, argues that "from the very beginning we must call into question any notions of pure traditions or pristine heritages. ... Ambiguous legacies, hybrid cultures. By hybrid, of course, we mean cross-cultural fertilization." Huebsch staked out a similar position earlier in the twentieth century: "The land that depends solely on indigenous writing has no standing in the large world of culture; the great books all come from lands that have ever drawn on foreign sources," he wrote. "Every language owes a debt to every other." ${ }^{5}$ For Huebsch, payment of the debt to hybridity involved featuring rather than concealing his own Jewishness, as West would do later with his blackness. Huebsch adopted as his press mark the seven-branched Jewish candelabra known like the nine-branched one of Hanukah as a menorah and described in Exodus 31-32. It is depicted on the frieze adorning the Arch of Titus in Rome commemorating destruction of the Jewish kingdom and temple in Jerusalem in $\mathrm{AD} 7 \mathrm{0}$. In a gesture that surely would have pleased the philosemitic Joyce, Huebsch used it on the title pages of works like Joyce's own Exiles when he published it in 1918.

Huebsch did not publish much work by African American authors through his own firm, but that changed when he joined the newly founded Viking Press in 1925 as vice-president, bringing his backlist with him. Unlike Huebsch but like many of their contemporaries in publishing, Viking's founders Harold Guinzburg and George Oppenheimer enjoyed college educations, Guinzberg at Harvard and Oppenheimer at Williams. In their very first year, Viking brought out James Weldon Johnson and Rosamond Johnson's The Book of American Negro Spirituals with splashy fanfare and followed it up with The Second Book of Negro Spirituals the next year, followed in turn by God's Trombones and the autobiographical Along this Way among other works. Viking published other high-profile African American books as well, including Richard Wright's Twelve Million Black Voices in the 1930 os and W. E. B. Du Bois's The World and Africa in the 1940s. Viking's Irish authors included James Joyce (whom Huebsch brought with him upon joining) and Sean 
O'Faolain; their Jewish ones, Muriel Rukeyser, Dorothy Parker, and Lillian Hellman; and their other modernists numbered Joyce, Lawrence, and Anderson from Huebsch's list along with John Steinbeck and the muckraking Upton Sinclair. Foreign additions included Franz Werfel and Stefan Zweig.

The pattern of publishing African American, Irish, and Jewish authors along with translations of foreign ones started by Huebsch at his own press and then at Viking continued in the rising house of Alfred A. Knopf, operated by Knopf together with his wife Blanche from 1915 onward. Knopf began chiefly with foreign authors, including Russians like Gogol and Turgenev. He also published the Irish writer Liam O'Flaherty's novel of betrayal during the Irish "Troubles," The Informer, along with modernist volumes like T. S. Eliot's Poems and The Sacred Wood (both 1920), Ezra Pound's Lustra and Pavannes and Divisions, all the major poetry of Wallace Stevens from Harmonium in 1923 onward, and after Huebsch migrated to Viking several D. H. Lawrence books. His Jewish titles included the first two plays of Lillian Hellman and Siegfried Sassoon's Prehistoric Burials. Those works all create interesting contexts for reading the major African American books that Knopf promoted, including both of Nella Larsen's novels, Quicksand and Passing, and particularly Langston Hughes's poetry from The Weary Blues in 1926 onward and important prose volumes like his autobiographical The Big Sea too. The Weary Blues made Hughes one of the first African American poets to be published by a major (or about to be major) firm in the United States. Despite occasional later tensions, especially during the $1930 \mathrm{O}$ when Blanche worried that Hughes's work was becoming too politically propagandistic, the ties between him and them remained tight. In 1941 Hughes wrote to them, "Dear Alfred and Blanche, This June marks for me twenty years of publication-largely thanks to you as my publishers. With my continued gratitude and affection ... Langston Hughes." Nor did the Knopfs shy away from controversy: they issued both Walter White's The Fire and the Flint about the Atlanta race riots, which other houses had rejected because of subject, and Carl Van Vechten's Nigger Heaven, touchy because of its title and its white authorship despite Van Vechten's close and admiring relationship to Harlem culture. Publishers like the Knopfs did not operate in isolation, of course, but as part of a network of connections and acquaintances which sometimes blossomed into friendships. In his memoir The Big Sea, itself published by Knopf, Langston Hughes has left a vivid portrait of attending a triple birthday 
party given by Van Vechten for himself, James Weldon Johnson, and Alfred A. Knopf Jr.

For several pleasant years, [Van Vechten] gave an annual birthday party for James Weldon Johnson, Young Alfred A. Knopf, Jr. and himself, for their birthdays fell on the same day. At the last of these parties, the year before Mr. Johnson died, on the Van Vechten table were three cakes, one red, one white, and one blue-the colors of our flag. They honored a Gentile, a Negro, and a Jew. But the differences of race did not occur to me until days later, when I thought back about the three colors and the three men. Carl Van Vechten is like that party. He never talks grandiloquently about democracy or Americanism. Nor makes a fetish of those qualities. But he lives them with sincerity—and humor. ${ }^{7}$

Hughes might have said the same thing about his own publisher Alfred Knopf's list, which displayed the same democratic qualities allied to an aristocracy of merit wherever it surfaced. Knopf's Borzoi book imprint materialized that credo in the books themselves, providing the same high-quality craftsmanship to every book regardless of the race, creed, or color of its author. They set a new standard for the industry.

The strength of such networks extended even to the one gentile house that published numerous black titles-Harcourt, Brace-through its Jewish vice president Joel Spingarn, first Knopf's favorite professor at Columbia and later his friend. While teaching comparative literature at Columbia for twelve years before his own dismissal in 1911 for introducing a resolution of support for a colleague who had himself been dismissed, Spingarn also instructed Alfred Harcourt and Donald Brace. Harcourt and Brace both worked at Henry Holt \& Co. until the restrictive policies there propelled them to resign and found their own firm, taking such upcoming authors as Sinclair Lewis with them. They promptly recruited their former teacher Spingarn first as literary adviser and then as vice president and partner. By that time Spingarn had thrown himself into biracial social activism and become first cofounder and then chairman of the board of the NAACP, where he allied himself closely with W. E. B. Du Bois. He put his comparative literature background to use at Harcourt, Brace by directing their European Library series, and his civil rights experience by recruiting African American writers. Under his guidance Harcourt, Brace promptly published Du Bois's prose Dark Shadows in 
1920, and in 1922 Claude McKay's first book of poems in the United States, Harlem Shadows, and James Weldon Johnson's Book of American Negro Poetry, along with work by Arna Bontemps, Sterling Brown, and other African Americans. They also published Carl Sandburg's The Chicago Race Riots, July 1919, Louis Untermeyer's influential anthology Modern American Poetry, and Sinclair Lewis's Main Street, while the European Library imprint featured work by the Frenchman Remy de Gourmont, the Italian Benedetto Croce, and the German Heinrich Mann. The book that made the firm's early reputation and finances, John Maynard Keynes's Economic Consequences of the Peace, opened important links to the Bloomsbury modernists in England, including E. M. Forster and Virginia Woolf along with their sometime fellow-traveler T. S. Eliot.

In 1917 the Harvard-educated Boni brothers came together with the flashy self-made product of the jazz age Horace Liveright to create Boni and Liveright, another upstart Jewish firm that would publish work by various ethnic groups along with modernist Anglophone and European writers of any ethnicity. For their first dozen titles they built upon the unexpected success of the Bonis' Little Leather Library, which had begun with minivolumes of Shakespeare stuffed into Whitman's candy boxes. The resultant and still-influential Modern Library series featured cheap reprints of Friedrich Nietzsche, Oscar Wilde, Fyodor Dostoevsky, and others at sixty cents a volume. They soon moved into more contemporary work as well, publishing the first books by the black writers Jean Toomer (who disliked being termed a "Negro" or any other racial marker), the West Indian Eric Walrond, and the novelist Jessie Fauset. Irish authors included Liam O'Flaherty, George Bernard Shaw, and W. B. Yeats, along with Irish Americans like Eugene O'Neill. Their Jewish writers numbered Dorothy Parker, Waldo Frank, Ben Hecht, and Mike Gold, reflecting a general left-liberal tilt. The firm even boasted perhaps the most distinguished assistant in New York publishing, the young Lillian Hellman. Other major modernist work included Hart Crane's White Buildings and The Bridge, William Faulkner's first two novels Soldier's Pay and Mosquitoes, Ernest Hemingway's In Our Time, and several works by Ezra Pound and Theodore Dreiser. Liveright also secured Pound's services as translator by agreeing to one of the most unusual clauses in publishing history, devised by Pound himself: "Mr. Liveright agrees not to demand Mr. Pound's signature on the translation of any work that Mr. Pound considers a disgrace to humanity or too imbecile to be borne." The Jewish character of the firm did not trouble the increasingly anti- 
Semitic Pound, who consistently valued Liveright's openness to modernist literature and recommended him to his friends, in 1920 even calling Liveright "a pearl among publishers." But it did bother William Faulkner, who like many people of his time associated Jews with Blacks. He therefore was happy to switch to Harcourt, Brace after two books with Boni and Liveright. "I'm going to be published by white folks now," he told his great-aunt Alabama Falkner McLean. "Harcourt Brace \& Co. bought me from Liveright. Much nicer there." T. S. Eliot expressed himself with even more vitriol about a slight delay in royalty payments. "I am sick of doing business with Jew publishers who will not carry out their part of the contract unless they are forced to," he told his American patron and fellow anti-Semite John Quinn. "I wish I could find a decent Christian publisher in New York." Ironically, Liveright continued to publish modernist work even though it often sold poorly. "Do you suppose I like to go on losing money on you miserable highbrows?" he twitted Pound at about the same time as Eliot's letter. "But no matter what you write, you know I always want to publish your poetry and I know that I do and will do more for it than anyone else."

The partnership of the Bonis and Liveright proved unstable: the brothers had operated a Greenwich Village bookshop that sponsored the avant-garde journal The Glebe, from whose sheets they had issued the breakthrough verse anthology Des Imagistes in 1914. In contrast, the brasher Liveright cut his teeth on Wall Street. Backed by money from his father-in-law, he had an up-and-down career there before leaving with a tidy pile made in bond trading. Ever the spendthrift, he began in 1924 to use money from the publishing house to support his growing involvement in Broadway productions, where he scored his greatest hit with the production of Dracula starring Bela Lugosi. Not surprisingly, by the mid-1920s the Bonis had left to found their own firm, A. and C. Boni, which published the signature anthology of the Harlem Renaissance, Alain Locke's The New Negro, among other works. Another influential refugee from the firm was Bennett Cerf, who served as vice president for two years before leaving in 1925 to found Random House, buying the Modern Library series to take with him.

Its iconic status makes The New Negro a particularly useful example of the importance of textual and bibliographic awareness to minority literature. Although our contemporary paperback editions present themselves as reprints, they display editorial interventions that alter the meaning of the work and, indeed, do not even include all of the origi- 
nal 1925 volume. The alterations to bibliographic codes loom larger here than those to linguistic ones. True, modern title pages label the work simply "The New Negro" rather than the more elastic "The New Negro: An Interpretation" of the original, which suggests one point of view among many. But even more important, modern paperbacks omit a key element of the title page, the bold statement "Book Decoration and Portraits by Winold Reiss," which gives the seventeen color illustrations by Reiss nearly coequal status with the verbal contents of the book. Reiss was a white artist born in Germany who emigrated to the United States, where he mentored among others Aaron Douglas, perhaps the most famous visual artist of the Harlem Renaissance. The original title page, then, proclaims the volume a biracial enterprise from the start, though of course with the African American editor Alain Locke playing the larger role. That signal also reminds us of the biracial nature of the contributors to the project, which included the white Albert Barnes, Paul Kellogg, and Melville Herskovits along with a host of African Americans from different generations. Finally, the imprint of Albert and Charles Boni reminds us of the marginality of the venue, a new Jewish publishing house in New York rather than a mainstream WASP one from New England.

The Bonis' heavy promotion of The New Negro exemplified another trait of the firm, its pioneering exploitation of modern commercial techniques for publicizing its products and, indeed, thinking of them as products. This resulted partly from the brief but important stint as early publicity director for the predecessor firm of Edward Bernays, nephew of Sigmund Freud (he recruited his famous uncle to the Boni and Liveright imprint) and devotee of modern advertising who had worked with the U.S. Committee on Public Information during World War I. He declared in Publisher's Weekly his devotion to supplementing traditional advertising with "propaganda and publicity, which proved such a powerful factor in the war." The New Negro grew of course, out of the Survey Graphic special issue "Harlem: Mecca of the New Negro," which in turn grew out of the famous Civic Club dinner that did so much to crystallize the New Negro movement and volume. ${ }^{9}$ That dinner had been organized ostensibly to promote publication of Jessie Fauset's 1924 novel There Is Confusion, an event marking a breakthrough into major promotion for a work by an African American author. Floyd Calvin, the young and talented new managing editor for the Eastern region of the important African American newspaper The Pittsburgh Courier, saw that importance at once. He declared in a column: 
Boni \& Liveright, the publishers, purchased liberal space in the notable publications, and their advertisement, which was complimentary in every detail, reads as follows ... We make mention of this because it marks the beginning of a new era in the treatment of colored writers. Heretofore they have received no such encouragement when their work was accepted for publication and but scant notice when it appeared ... it is heartening to see this new attitude. We trust the reception of Miss Fauset's book will make the way even easier for other literary aspirants who choose to follow. ${ }^{10}$

The groundbreaking publicity campaigns of Boni and Liveright, along with other new publishers, for minority literature represented both a desire to procure it a wider audience and a commitment to helping to create that audience. That applied to Irish, Jewish, and other modernist writers along with its African American ones.

Four books influential in different ways published by Boni and Liveright before the Boni brothers left exemplify the original firm's ethnic range and create a new context for viewing cultural works often kept apart from one another. Earliest came Irish Fairy and Folk Tales, edited by W. B. Yeats and one of the first titles in The Modern Library Series. Originally published in London at the start of the Celtic Twilight movement, the volume helped to inject ideas of folkloric and mythic structure and content into the Irish Renaissance and modernism in general. Its numerous subdivisions included separate groupings on fairies, ghosts, paradises, giants, and others. The Irish tales also carried a nationalist and ethnic edge, recovering or perhaps creating a neglected tradition, as books of stories by various racial groups or by women do in our own time. By this time Macmillan had become Yeats's main publisher for his own work, and he took increasing control over the physical appearance of his books with them, including design and covers. That was not the case with Modern Library, but the weakness of copyright protection for foreign work even after passage of the Chace Act in 1891 and the flattery of inclusion in the ranks of recognized ancient and modern masters proved attractive. So, too, did the additional if small fee and the outreach to American audiences. Yeats went on to publish two more books with Boni and Liveright. Next came a reprint for the Modern Library of his one-volume selection, The Poems of William Blake, originally published in London in 1893. Part of Yeats's lifelong devotion to his early roman- 
tic precursor, the book sported an introduction in which Yeats began by claiming an improbable Irish ancestry for Blake. The Celtic theme continued in Yeats's final volume for Boni and Liveright, where he contributed a preface to Arland Ussher's translation of Brian Merriman's late eighteenth-century Gaelic poem The Midnight Court. An exuberant satire against growing sexual repression in Catholic Ireland, the poem completed the trilogy of Irish (or in the case of Blake, pseudo-Irish) materials that marked all three of Yeats's contributions to the firm's growing list.

Yeats's Irish Fairy and Folk Tales was followed by the Jewish author and critic Waldo Frank's Our America (1919), which passionately argued for creation of "a new historical and spiritual consciousness" in revolt against "the academies and institutions which would whittle America down to a few stale realities current fifty years ago when our land in all but the political surface of its life was yet a colony of Britain."11 Inclined more toward pluralist conceptions like those of Horace Kallen, Frank saw a welter of new cultures contributing towards an American renaissance that ranged from indigenous Native Americans to immigrant Jews. He devoted an entire chapter to the latter group, arguing that they had fallen into the wasteland of contemporary American materialism but showed signs of rising up again artistically and spiritually, and most of another chapter to Mexicans and Native Americans. And polyglot New York fascinated Frank, particularly its mix of European ethnic groups including Jews and Celts. Frank also saw clearly the role of firms like Boni and Liveright in dispensing minority and dissident literature, and in creating audiences for it. He made that plain repeatedly, as in his chapter on Horace Liveright in the book Time Exposures, also published by that firm. In the chapter entitled "One Hundred Per Cent American" Franks satirized the Ku Klux Klan, Security Leagues, and Vice Society by having them denounce Liveright in these terms: "He has sponsored half the advanced novelists who pollute our homes, half the radical thinkers who defile our customs, half the free verse poets who corrupt our English. He has defiantly come out for minorities in a land where the Majority is sacred. He has fought such noble democratic measures as Censorship, as Clean Book Bills-and with his own money!" 12

Frank particularly admired the rise of an African American culture in New York and took the manuscript of the first major novel of the Harlem Renaissance, Jean Toomer's Cane, to his own publisher Horace Liveright. He not only persuaded Liveright to issue a contract but telegraphed the news to Toomer and then wrote a foreword for the first edition. There 
he praised "the book's chaos of verse, tale, drama, its rhythmic rolling shift from lyricism to narrative" in a way that implicitly aligned it with other modernist work. Cane too deployed jumps between discrete units, shifting forms, a mix of elevated and everyday language, and a sense of mythic presences behind everyday occurrences. But Liveright's effort to promote Toomer as a "Negro" writer ran into opposition from Toomer himself. The light-skinned Toomer resisted simplistic racial categorization and insisted on his own mixed origins. "Racially, I seem to have (who knows for sure) seven blood mixtures: French, Dutch, Welsh, Negro, German, Jewish, and Indian," he wrote in a 1922 letter to the Liberator magazine. "Because of these, my position in America has been a curious one." ${ }^{13}$ For Toomer, the categories used in the America of his day created false divisions among human beings. In a preface to an unpublished autobiography Toomer argued that "If I have to say 'colored,' 'white,' 'jew,' 'gentile, and so forth, I will unwittingly do my bit toward reinforcing the limited views of mankind which dismember mankind into mutually repellant factions." Accordingly, Toomer refused to identify himself as a "Negro" for Liveright, telling him, "I must insist that you never use such a word, such a thought again."

Those works throw an unexpected crosslight on the fourth example, that famous modernist poem The Waste Land (1922) by T. S. Eliot, who had previously published in America with Alfred Knopf and like Faulkner would later escape to the more ethnically satisfactory Harcourt, Brace (despite the presence of Joel Spingarn there). Before Harcourt, Brace, the American editions of Eliot's major early books came from Jewish publishers, the only ones who would touch them. The list with Knopf began with the pamphlet Ezra Pound: His Metric and Poetry, published along with Pound's own Lustra in 1917. Next came Poems (1920), incorporating both the Ara Vos Prec and Prufrock and Other Observations volumes from England, and then the prose of The Sacred Wood. Unable to reach satisfactory terms with Knopf for The Waste Land, Eliot switched to Liveright, whom Pound had recommended. That poem's presence in the Boni and Liveright list recontextualizes it in terms of African American, Jewish, and Irish modernist work and reveals its affinities with all three groupings. And Liveright's worry that The Waste Land was too short for a separate book led to Eliot's composition of the famous prose notes. Often seen as a pure product of WASP high culture, The Waste Land in the context of book history instead discloses its sometimes lost connections to other ethnic literatures and to popular cultures in general, as 
Eliot scholarship has increasingly recognized. Indeed, its very title page proclaims its debt to modern Jewish publishing even as Eliot himself deprecated that group.

The poem's (and the manuscript's) invocations of black and Irish culture match its material presence among such works in the Boni and Liveright lists in both specific allusions and in overall structure and rhythm. In his essay "Hidden Name and Complex Fate" Ralph Ellison confessed that the poem "seized my mind" because of that fusion. "Somehow its rhythms were even closer to those of jazz than were those of the Negro poets, and even though I could not understand then, its range of allusion was as mixed and varied as that of Louis Armstrong" (160). Besides its rhythms, the poem reframed specific jazz and popular song works, such as "The Shakespearian Rag" for lines 128-30, in the middle of the "Game of Chess" section. That popular song from the 1912 Ziegfeld Follies provided the phrases "That Shakespearian rag, Most intelligent, very elegant" cited by Eliot. ${ }^{14}$ They not only allude to a past song but also describe Eliot's own poem, and particularly its bringing together of what we often too simply dichotomize as high culture (here, Shakespeare, once himself part of the popular culture of his day) and popular jazz or ragtime. Such divisions are not mere illusion, but neither can they claim an absolute status, as Ellison's comparison of T. S. Eliot's rhythms to those of Louis Armstrong reminds us.

The confluence of Black, Irish, and Jewish elements with high culture loomed even larger in the original opening section of The Waste Land, which Eliot deleted at Pound's instigation and which featured a Boston Irish pub crawl in which one character sings lines from George M. Cohan's song "Harrigan": "I'm proud of all the Irish blood that's in me, / There's not a man can say a word agin me." ${ }^{15}$ The same section also invokes lines from two more popular songs-Thomas Allen's 1904 "The Watermelon Vine" (also known as "Lindy Lou") and Mae Sloan's 1901 "My Evaline"-before citing with slight alteration lines from "The Cubanola Glide" by the Irish-Jewish songwriting team of Vincent Bryan (words) and Harry von Tilzer (music): “Tease, squeeze, lovin' and wooin' / Oh, babe, what are you doin'?" All three belonged to the genre then known as "coon songs," which despite the racist sound of the term could vary from crude stereotypes to more sophisticated ventriloquism and finally to songs having nothing to do with African Americans at all and which especially involved Irish people. Along with the minstrel songs and Irish names, Eliot carefully included a reference to the Jewish "little 
Ben Levin the tailor," whose name and occupation signal his ethnicity. It would be hard to imagine an opening more indebted to popular culture of different groups. Its polyglot nature and its venue of publication reinforce each other. In that way, the poem's material form reenacts its content, connecting it to multiple networks of modernism and to the insistent references to Jews, Blacks, and Irish that run throughout Eliot's published as well as unpublished work, for instance to Rachel née Rabinowitz in "Sweeney Among the Nightingales," to Sweeney himself in the Sweeney poems, and to King Bolo in the March Hare notebook. To see that connection, as with so many other works of the modernist period, we need to turn from current readings that often misread and look again at original bibliographic contexts and their implications.

\section{Notes}

1. The best account of Robeson's performance is Lisa Barg, "Paul Robeson's Ballad for Americans: Race and the Cultural Politics of 'People's Music," Journal of the Society for American Music 2.1 (2008): 27-70. The now-standard edition of Tolson is "Harlem Gallery" and Other Poems of Melvin B. Tolson, ed. Raymond Nelson (Charlottesville: University of Virginia Press, 1999), 217. See, too, George Bornstein, The Colors of Zion: Blacks, Jews, and Irish, 1845-1945 (Cambridge: Harvard University Press, 2011), which addresses some of the same material as the present essay.

2. Two extended studies applying bibliographic codes to modernist literature are Jerome McGann, Black Riders: The Visible Language of Modernism (Princeton: Princeton University Press, 1993), and George Bornstein, Material Modernism: The Politics of the Page (New York: Cambridge University Press, 2001). The best study applying those codes to African American literature remains George Hutchinson, The Harlem Renaissance in Black and White (Cambridge: The Belknap Press of Harvard University Press, 1995), from which I am particularly indebted to chapter 12, "Black Writing and Modernist American Publishing."

3. See Jules Chametzky, From the Ghetto: The Fiction of Abraham Cahan (Amherst: University of Massachusetts Press, 1977), 67, and Charles A. Madison, Jewish Publishing in America: The Impact of Jewish Writing on American Culture (New York: Sanhedrin Press, 1976), 251.

4. Alfred Harcourt, "Publishing in New York," in Publishers on Publishing, ed. Gerald Gross (New York: R. R. Bowker and Grosset \& Dunlap, 1961), 255.

5. For the Christopher Morley remark, see John Tebbel's authoritative A History of Book Publishing in the United States, vol. III (New York: R. R. Bowker, 1978), 117. Cornel West, "Beyond Multiculturalism \& Eurocentrism," in his Prophetic Thought in Postmodern Times, vol. 1 (Monroe, ME: Common Courage Press), 4. For Huebsch's own comment see Publishers on Publishing, 298-99.

6. Randolph Lewis, "Langston Hughes and Alfred A. Knopf, Inc., 1925-1935" Library Chronicle of the University of Texas 22, no. 4 (1992): 62. 
7. Langston Hughes, The Big Sea: An Autobiography (New York: Knopf, 1940), 254-55.

8. Pound's contract with Liveright is quoted in Noel Stock, The Life of Ezra Pound (New York: Pantheon Books, 1970), 246; for the "pearl among publishers" comment see Pound's letter to John Quinn, June 20, 1920. Ironically, Quinn was himself strongly anti-Semitic. For the Faulkner remark see William Faulkner, Selected Letters (New York: Viking, 1978), 41. Eliot's March 12, 1923, letter to John Quinn is cited in Tom Dardis, Firebrand: The Life of Horace Liveright (New York: Random House, 1995), 97-98, which also quotes Pound's letter about Liveright as "pearl among publishers" on 86 and Liveright's letter to Pound on 101.

9. Bernays is quoted in James C. Davis, Commerce in Color: Race, Consumer Culture, and American Literature, 1893-1933 (Ann Arbor: University of Michigan Press, 2007), 184. A good short account of the much-discussed Civic Club dinner and its complicated maneuvering may be found in Hutchinson, Harlem Renaissance, 390-92.

10. Floyd J. Calvin, "The Digest," Pittsburgh Courier, April 19, 1924, 21.

11. Waldo Frank, Our America (New York: Boni and Liveright, 1919), 9.

12. Waldo Frank, Time Exposures by Search Light (New York: Boni and Liveright, 1926), 111.

13. Jean Toomer, Cane, Introduction by Arna Bontemps (New York: Harper \& Row, 1969), viii. See Charles T. Davis, "Jean Toomer and the South," Studies in the Literary Imagination 7, no. 2 (Fall 1974): 23-37, for a good general discussion of the subject. The second remark is quoted in George Hutchinson, "Jean Toomer and American Racial Discourse," Texas Studies in Literature and Language 35, no. 2 (Summer 1993): 230. The Toomer papers are now in the Beinecke Library, Yale University. Toomer's letter to Liveright may be found in A Jean Toomer Reader: Selected Unpublished Writings (New York: Oxford University Press, 1993), 94-95.

14. For a transcription of the lyrics and music, see Lawrence Rainey, The Annotated Waste Land with Eliot's Contemporary Prose (New Haven: Yale University Press, 2005), 96-99.

15. T. S. Eliot, The Waste Land: A Facsimile and Transcript of the Original Drafts, ed. Valerie Eliot (New York: Harcourt Brace Jovanovich, 1971), 5. 


\author{
Ifeoma Kiddoe Nwankwo
}

\title{
MORE THAN MCKAY AND GUILLÉN
}

\author{
The Caribbean in Hughes and Bontemps's \\ The Poetry of the Negro (1949)
}

Introduction

When Langston Hughes writes, "I am ashamed for the black poet who says 'I want to be a poet, not a Negro poet,' as though his own racial world were not as interesting as any other world," he highlights a devaluation of self and community that, he is arguing, has too frequently characterized Black artists' approaches to their work. It is "the mountain standing in the way of any true Negro art in America," that can only be overcome when Negro artists view art as an expression of their "individual darkskinned selves." In formulating this argument, Hughes intervenes in the swirling debates about the definitions and parameters of blackness and Black art; the ways the Black artist should see and articulate him- or herself and the purpose of his or her art; what the content and form of his or her art should be; as well as the work "Black art" should be doing on the page and/or in the world. ${ }^{2}$ Hughes also takes a stance on these recurring questions through editorial decision making in The Poetry of the Negro, a collection he coedited with Arna Bontemps in 1949. This essay is an in-depth examination of the first edition of The Poetry of the Negro and the answers it offers to these questions about the form, content, purpose, and production of Negro art.

Each of The Poetry of the Negro's three sections- "Negro Poets of the U.S.A.," "Tributary Poems by Non-Negroes," and "The Caribbean"implicitly articulates the editors' positions on the aforementioned questions about the Black artist and Black art. This essay illustrates that the Caribbean section is particularly revealing. The region's racial complexity demands a more elastic and dynamic selection framework than the other two sections, not only making simple answers to the questions 
impossible but also calling attention to Bontemps and Hughes's putting forward a distinctive conception of what an anthology of Black literature should contain and aim to do.

The Poetry of the Negro was edited and published in 1949 by two individuals who came of (artistic) age during the "New Negro Renaissance," facts that situate it as part of a context full of overlapping and intersecting artistic and political movements in the Black Americas, and the Black Atlantic more generally. In addition to the New Negro Renaissance, the decades between 1920 and 1950 saw the rise of naturalism and realism in the United States, Negritude in the Francophone world, and the entry of Black writers from the British Caribbean into the intellectual and aesthetic discourse on the region through novels, poems, literary magazines, and journals to a degree never before seen. Each of these movements brought with it debates about the significance and definition of the Black artist, Black literature, and Black poetry. Hughes and Bontemps use anthology editing as a way of narrating and intervening in these movements and debates.

\section{The Poetry of the Negro: An Overview}

The primary organizing principle of The Poetry of the Negro is "the Negro's experience in the Western world." The expression of that experience, as Hughes and Bontemps view it, includes writing by non-Negroes as well as writing by individuals who belong to "the group which is defined in the United States as Negro" (vii) about topics other than race. They reiterate this viewpoint throughout the preface with statements such as "the title of this volume has somewhat more reference to a theme and a point of view than to the racial identity of some of its contributors" (vii). They note, for example, that the poetry of the free men of color from Louisiana "scarcely touched racial feeling" because "the members of this group had not been taught to link themselves personally with the condition of the slaves" (ix).

The definition of "the Poetry of the Negro" posited by Bontemps and Hughes through their preface oscillates between fixity and fluidity-it is at once the product of an experience lived by a specific group of people (the Negro's experience in the Western world) and an artistic treatment of that experience by members of the group and others ("a theme and a point of view" rather than "the racial identity of some of [the] contribu- 
tors"). The editors are not seeking to present or establish a singular image of "the Negro experience in the Western world" but rather to showcase the range of aesthetic paradigms, tropes, images, and modes of expression that such experience has made possible.

If the compilers had sought for a racial idiom in verse form among Negroes, they should have concerned themselves with . . . Negro spirituals ... and other spontaneous lyric ... [that] suggest a kind of poetry that is racially distinctive.... But the present anthology consists of poems written within that tradition, by Negroes as well as others. (vii)

Here, the two editor-poets avow the existence of a racially distinctive "kind of poetry" while also marking that "kind of poetry" as a tradition that can be drawn upon by individuals from a range of racial backgrounds. "The Poetry of the Negro" has a unique essence, they seem to be arguing, but that essence has been influenced and expressed by others who are not "Negro." The Negro in Western civilization has been "exposed to overwhelming historical and sociological pressures that are bound to be reflected in the verse he has written and inspired. The fact that he has used poetry as a form of expression has also brought him into contact with literary trends and influences" (ix). "The Negro" referenced in the title of the volume, then, is intended by the editors to index a sociopolitical category (defined in the United States as Negro), an experience (the Negro experience in the Western world), and an aesthetic tradition, as well as an ongoing conversation between "the Negro" himself and the world(s) around him.

\section{Reception and Circulation of The Poetry of the Negro}

The book was picked up by libraries in smaller cities like Hayward, California (Daily Review) and Hershey, Pennsylvania (Lebanon Daily News), as well as larger cities including Chicago (the Star). It was widely reviewed. The Star praises the collection, noting, "The Poetry of the Negro will stand for years as the best most illuminating collection of its kind." The Chicago Defender includes it in a piece recognizing Langston Hughes's prolific publishing. ${ }^{5}$ The Kingsport Times (TN) in a review entitled "300 years of Negro Poetry Bound in Doubleday Collection" cel- 
ebrates the anthology's unique elements, including the "supplement of Caribbean verse much of which is translated into English for the first time" and "a section of poems about Negroes and Negro life written by Whites, much of which will prove a revelation to the average reader." It ends by emphasizing, "Doubleday was fortunate to find two men to edit 'The Poetry of the Negro' who have been so much a part of American poetry." ${ }^{6}$ First Lady Eleanor Roosevelt identified it as a "book all Americans should read."

Some reviewers did take issue with the broad scope of the anthology. The Kirkus Review notes that "while it may lack the unity and special charm of the more selective anthologies like Caroling Dusk, The Poetry of the Negro will take its place as a standard collection, representing the best poems by and about the Negro." ${ }^{8}$ John Lovell, in a review published in the Journal of Negro Education, calls the volume too "vast and arid," and notes that Hughes and Bontemps "would have spent their time more profitably if they had made an anthology say of one-tenth or onetwentieth this size containing the really powerful things in their present volume." ${ }^{\prime \prime}$ He goes further, though, criticizing the editors' selection strategy for the West Indian poets and proposing that readers "simply dismiss the non-U.S.A., non-Negro writers as beyond the pale of a thoroughly unified principle and settle down to the native American Negroes." ${ }^{\prime 10}$

A number of reviewers mention what they read as having a relatively depressing tone. First Lady Roosevelt admits, "I'm afraid I can't say that many of us will enjoy this poetry. Nevertheless, it should be read. Over and over again the bitterness and disillusionment and the sorrow of a race appear on its pages. The poems are all interesting and some of them are beautiful." 11 The tone, she implies, is a result of the actual suffering this population has seen, and the poetry is a reflection of that experience.

In a similar vein, other reviewers of The Poetry of the Negro see it as or expect it to be a textual embodiment of the entire history of Black expressive culture, rather than just of poetry written by Blacks. A reviewer writing for the New York Times complains, "There are no folksongs (spirituals, blues, jubilees) and no explanation of why they are omitted. For these, many readers would gladly sacrifice those spacious and fussy tributary poems." ${ }^{12}$ John Frederick Nims, reviewing the anthology for the Chicago Daily Tribune, calls the anthology a "solid and satisfying volume," confessing that he did not know the Negro poetry tradition went back two hundred years and was "surprised and pleased by the 18 th century primitives, perhaps derived from the attitudes and 
moods that inspired the spirituals." ${ }^{33}$ The Poetry of the Negro, for Nims, is a transparent history of African American oppression and its impact on the population's literary capacity: "The very silences and inadequacies of the earlier work testify to the difficulties of an oppressed people." Although he notes that the later work is better he still says that it tends to be derivative. A second "artistic defect" evident in the volume, from his perspective, is "that a good deal of the poetry is, by intention and passion, propaganda poetry-how could it fail to be when the Negro artist felt (above all) the need for [a] change of status." He finds the sections on the Caribbean and the Tributary Poems by Non-Negroes "somewhat less compelling in their interest ... but they help to fill in the picture sketched so starkly in the first part." 14

A review in The Tiger's Eye expresses a slightly different perspective, highlighting the aesthetic value and implications of the anthology: "The most valuable point this book proves is that a good poem is a good poem whether it is written by a white man or a negro or a whoever." ${ }^{15}$ Another in the New York Herald Tribune simultaneously praises the anthology as a text that "can help the reader understand the Negro's emotions, longings and values" and points to it as evidence of "the thoughtful development of Negro talent to the point where one questions the necessity (other than for its social evidence) of the specialization of 'Negro' in the title."'16

\section{Sister and Brother Anthologies}

These reviewers would have had a number of anthologies with which to compare The Poetry of the Negro since artists, writers, and scholars during this period often sought to articulate their stances on the proper definition, form, content, purpose, and audience of Black literature by editing anthologies. The three decades between 1920 and 1950 saw the publication of a number of poetry anthologies, including James Weldon Johnson's The Book of American Negro Poetry (1922), four editions of Robert Kerlin's Negro Poets and Their Poems (1923, 1935, 1940, 1947), Newman Ivey White and Walter Clinton Jackson's An Anthology of Verse by American Negroes (1924), and Countee Cullen's Caroling Dusk: An Anthology of Verse by Negro Poets (1927), as well as Beatrice Murphy's Negro Voices (1938) and Ebony Rhythms (1948). ${ }^{17}$ In the eyes of their editors, these anthologies serve primarily to encourage Whites' recognition of 
Blacks' intellectual capacity, equality, and literary skill. ${ }^{18}$ Most of them work toward this end by including only U.S. Black writers in their anthologies and emphasizing U.S. Black writers' connections and claims to broader American and English literary traditions. ${ }^{19}$

Robert Kerlin (Negro Poets and Their Poems) positions the Black authors and cantors of spirituals as the foreparents of canonical Black and White American writers: "those untaught singers of the old plantations of the South, whose melodious lullabies to the babes of both races entered with genius-quickening power into the souls of Poe and Lanier, Dunbar and Cotter." ${ }^{20}$ He makes the point that the Negro poet, like other American poets, "is the heir of Anglo-Saxon culture" (3) and "has been nurtured in the same spiritual soil as his contemporary of the White race, the same traditions of language, form, imagery, and idea as his" (3). ${ }^{21}$

In the foreword to Caroling Dusk: An Anthology of Verse by Negro Poets (1927), Countee Cullen writes, "Since theirs is also the heritage of the English language, their work will not present any serious aberration from the poetic tendencies of their times." ${ }^{22} \mathrm{He}$ notes further that "as heretical as it may sound, there is the probability that Negro poets, dependent as they are on the English language, may have more to gain from the rich background of English and American poetry than from any nebulous atavistic yearnings toward an African inheritance." ${ }^{23}$

Beatrice Murphy, in Negro Voices (1938), links the production of her anthology to the recognition of the Negro as a contributor to the American nation: "If this anthology does nothing more than to convince the American public of the great potentialities within the race which have not yet been brought to light, and it serves as continuing evidence that the Negro is continuing to make his contribution to American civilization, then it has been well worth the effort."24

In the preface to his 1922 anthology, The Book of American Negro Poetry, James Weldon Johnson ties U.S. Black writers to American, Anglophone, and transnational Black literatures and histories.

The public, generally speaking, does not know that there are American Negro poets-to supply this lack of information is, alone, a work worthy of somebody's effort. Moreover, the matter of Negro poets and the production of literature by the colored people in this country involves more than supplying information that is lacking. ${ }^{25}$ 
Johnson argues, though, that supplying information about the existence of Negro poets is not just filling in a knowledge gap. Producing and showcasing great literature and art is a crucial way for Blacks to demonstrate their greatness as a people and to be seen as making a "distinctive and valuable contribution to American poetry."26

For the most of the editors, though, this interest in situating U.S. Black writers in relation to broader U.S. and English traditions does not lead to an investment in using the pages of their anthologies to link those writers to a wider transnational Black one. James Weldon Johnson is one of the few for whom it does. Johnson's definition of "Negro poetry," as posited in his preface, includes the writing produced by people of African descent in the Caribbean and Latin America. He takes pains to contextualize the U.S.-born poets that constitute the bulk of the volume in relation to Black poets from these other parts of the world. He includes extensive discussion of the Cuban poet Plácido (including a detailed biography and an analysis of one of his sonnets) along with his references to Plácido's contemporary and compatriot, Juan Francisco Manzano, Machado de Assis of Brazil, and the Haitian writers Vieux and Durand. He goes on to make an intriguing argument.

The colored poets of greater universality have come out of the Latin-American countries rather than out of the United States ... [because] the colored poet in the United States labors within limitations which he cannot easily pass over. He is always on the defensive or the offensive. The pressure upon him to be propagandic is well nigh irresistible. These conditions are suffocating to breadth and to real art in poetry ... the colored poet of Latin America can voice the national spirit without any reservations. And he will be rewarded without any reservations, whether it be to place him among the great or declare him the greatest. ... So I think it is probable that the first world-acknowledged Aframerican poet will come out of Latin America. Against this probability, of course, is the great advantage possessed by the colored poet in the United States of writing in the world-conquering English language. ${ }^{27}$

His perception that these writers produce poetry that is more "universal" than that of their U.S. peers is based on his belief that they have greater access to "the national spirit" of their countries. Johnson's switch between 
the terms Negro and Aframerican is noteworthy because it positions $\mathrm{Ne}$ gro as a nationally bounded identifier and Aframerican as a transnational term that indexes continental origin and residence. Although, as he sees them, both populations are connected by their common status as "colored," they cannot be painted with a single broad brush and/or described using the same terms. He allows for the possibility that they may not all be considered "Negro" in their own countries and that they may not define themselves as such.

The existence of these anthologies and the stances of their editors on the core questions of the definition, content, form, audience, and purpose of "Negro poetry" illustrate that in editing The Poetry of the Negro, Hughes and Bontemps were definitely wading into challenging waters. Their inclusion of both poems by U.S. Blacks that do not explicitly treat race and also those of European and U.S. White poets sheds significant light on their interest in exploring a flexible definition of "the poetry of the Negro." It is the Caribbean section, however, that lays bare their wrangling with these questions and their struggle with the impossibility of a solitary definitive answer.

The Negro Poets of the U.S.A.

In the "Negro Poets of the U.S.A." section, whether a poem qualifies as "poetry of the Negro" is based primarily on the poet's race and country of birth. In this, The Poetry of the Negro seems to replicate contemporaneous anthologies' basic definition of Negro poetry as poetry written by people who "belonged to the group, which is defined in the United States as Negro" (vii). As might be expected, most of the poems in this section are either first-person-narrated poems written in the voice of a Black speaker commenting on an aspect of Black life or third-person-narrated poems that speak about an aspect of the "experience of the Negro in the Western world."

George Moses Horton's "On Liberty and Slavery" and James Weldon Johnson's "Fifty Years 1863-1913" exemplify the first-person poems. The speaker in "On Liberty and Slavery" is a slave, likely Horton himself, calling on Heaven and Liberty to free him from "this slavish chain" (line 2) and "to soothe the pain-to quell the grief / and anguish of a slave" (lines 11-12). The voice in "Fifty Years" is one Black man speaking to "brothers" (line 4) "on the Fiftieth Anniversary / of the Signing / of the 
Emancipation Proclamation" (lines 1-3) reminding them that "this land is ours by right of birth / this land is ours by right of toil / we helped to turn its virgin earth / our sweat is in its fruitful soil" (lines 20-24).

The third-person poems include Frances E. W. Harper's "The Slave Auction" and Frank Horne's "On Seeing Two Brown Boys in a Catholic Church." The speaker in "The Slave Auction" describes the emotional scene surrounding the auction and sale of children, women, and men into slavery. The story is told in the third person: "The sale beganyoung girls were there" (line 1). But it is clear that the speaker sympathizes or empathizes with the individuals being sold, their families, and their communities: "And mothers stood with streaming eyes / and saw their dearest children sold / Unheeded rose their bitter cries / While tyrants bartered them for gold" (lines 5-8). The speaker in Horne's poem actually addresses the two brown boys: "it is fitting that you be here / little brown boys / with Christ-like eyes / and curling hair" (lines 1-4).

The "Negro Poets of the U.S.A." section also includes poems that appear to center on an aspect of the broader human condition without any specific reference to race, including Phillis Wheatley's "On Imagination" and Angelina Weld Grimkés "A Winter Twilight." Although the collection does not include any poems by Louisiana freemen of color, Hughes and Bontemps include this population in their history of Negro poetry. They are part of the history even though they "had not been taught to link themselves personally with the condition of the slaves, and their poetry scarcely touched racial feeling" (ix). The section undoubtedly illustrates Hughes and Bontemps's statement that "where the author is Negro any theme is considered within" to be part of "the poetry of the Negro" (vii).

\section{Tributary Poems by Non-Negroes}

The "Tributary Poems by Non-Negroes" section features poems by White American and European poets including Walt Whitman, William Blake, William Wordsworth, Henry Wadsworth Longfellow, and John Greenleaf Whittier. The poems range from those written in the voice of the Negro him- or herself to those written by someone observing him or her. The first-person verses include some from Blake's "The Little Black Boy." The third-person poems include Whitman's renderings of encounters with "the runaway slave."28 
Hughes and Bontemps do not share their rationale for creating this section or for the poems they chose to include therein. One can surmise that, in these editors' eyes, the poems fall under the rubric of "the poetry he [the Negro] inspired others to write" (viii). The implication is that the poetry of the Negro includes poetry about the Negro as well as poetry written by him or her. They are arguing, then, for attentiveness to the impact of the reciprocal gazes of White and Black toward each other on the definition and content of the Western literary tradition in general, and Black literary history in particular. As is clear from the commitment to a racially based definition of Negro poetry that Hughes and Bontemps show in the first section of the volume, they do not wish to do away with it. They seem to be suggesting, though, that accepting it as the only defining characteristic is fundamentally limiting, and not sufficiently reflective of the true scope of the Negro's presence in and impact on the Western world. ${ }^{29}$

This section highlights a tension that is hinted at in Hughes and Bontemps's statements about and poem selection in the "Negro Poets of the U.S.A." section and in their reference to the Louisiana men of color whose poetry "scarcely touched on racial feeling"; it is a tension between a vision of Negro poetry as the expression of the Negro's experience from his own soul and pen and of Negro poetry as an aesthetic or artistic project that may not necessarily (1) come from a Black person's soul or pen or (2) express anything that is explicitly about the Negro experience in the Western world. Again, then, we see Hughes and Bontemps's willingness to sit with fungibility and imprecision in their approach to articulating (through editing) exactly what makes poetry "Negro."

\section{The Caribbean}

The Caribbean section of Poetry of the Negro includes forty-one poets. It is divided by country, with Jamaica (seventeen poets) and Haiti (sixteen poets) featured most prominently. Poets from Cuba, Martinique, British Guiana, British Honduras, Barbados, Trinidad, and French Guiana are also represented. ${ }^{30}$

In their prefatory discussion of the Caribbean section, Hughes and Bontemps make peace with the fact that neither their inclusion of the Caribbean nor their selection of particular poems and poets from the region meshes with conventional understandings about definitions of 
Negro poetry, including the ones they themselves posit at other points in their preface.

The common thread, of course, is the Negro's experience in the Western world. Where the author is a Negro, any comment on any subject is considered within this limit. Poems by others are included only when they touch the subject directly, except in the case of the Caribbean countries, where a departure from this principle seemed necessary in a few cases in order to make representative selections. (vii)

Representative of what, though? Are they suggesting that their selections adumbrate which poems and poets are "representative" of the Caribbean, in general, or of poetry in the Caribbean or of "the poetry of the Negro" in the Caribbean, in particular? These questions become even more vexed once we take into consideration their very next statement.

Another factor, too, blurred this logic a little. Racial distinctions vary from country to country. Any effort to apply the yardstick of the United States to the other Americas is likely to confuse more than it clarifies. No such attempt was made by the compilers. (vii)

They are admitting that their stated focus, "the poetry of the Negro," is always already a moving or, at the very least, dynamic target, and explicitly stating their willingness to take on that dynamism. Hughes and Bontemps go on to describe the fungibility of their topic/target by saying, "In the predominantly Negro countries around the Caribbean, selections of representative poems were made sometimes without respect either to racial implications in the verses or to the identity of the poets" (viii).

A closer examination of the Jamaican poets included in the anthology reveals the types of choices Hughes and Bontemps make in their construction of the Caribbean section, and the extent to which, through those decisions, they posit a definition of "the poetry of the Negro" that confronts complexities of race not addressed by any of their anthologyediting contemporaries. Although individuals like Marson and McKay appear, most of the Jamaican writers included in The Poetry of the Negro are British Creoles-the American-born children of Europeans, individuals who would likely have been classified as White in the United States (discussed in the next section of this chapter). ${ }^{31}$

Hughes and Bontemps showcase several Jamaican poets whose biog- 
raphies and corpuses suggest that they identify as Negro and/or would be classified as Negro in the United States. Among these is Jamaica's Una Marson. Her biographical note in The Poetry of the Negro describes her as having "had a brilliant career as a journalist, lecturer, and poet," working in London "with the League of Colored Peoples from 1933 to 1935," accompanying Haile Selassie "to the meeting of the League of Nations at which he undertook to deal with the Italo-Ethiopian problem," and serving as "editor and broadcaster in the West Indies Program of the BBC, London, from 1941 to 1946 " (402).

The speaker in Marson's poem "Hunted" likens herself to a "hunted hare" trying to evade a pack of dogs. She says, "The hunted hare seeks out some dark retreat / And hopes the pulsing pack will pass him by" (lines 1-2). The poem goes on to use hunting as a metaphor for a romantic relationship. It begins in the voice of a person observing a hare. Gradually the person recognizes the parallels between her experience and that of the hare: "So hunted still by love's relentless might / ... I seek some refuge, hidden from his sight" (lines 5, 7). Reeling from a love lost, the speaker wishes to find a refuge to which to escape and forget the pain. Although its focus on the hunted suggests that it is written from the perspective of the marginalized, the poem has no explicitly racial markers.

The second Marson poem in The Poetry of the Negro is "Nightfall," a poem about absent love. It begins "How tender the heart grows / At the twilight hour" (lines 1-2). Loneliness and pain are the poem's two key themes. Twilight, for the speaker, intensifies both for her, so she wishes for night to come so she may have relief. Although further research into their correspondence would be needed to uncover their rationale, it is worth noting that Hughes and Bontemps include two of Marson's least political poems that also do not feature any racial markers.

Hughes and Bontemps do include more explicitly political poems by Walter Adolphe Roberts, a Jamaican poet who spent much of his life in the United States. His biographical note in Poetry of the Negro states:

Walter Adolphe Roberts ... grew up in the town of Mandeville and became a reporter on the Daily Gleaner at the age of sixteen. Two years later he arrived in the United States and began a journalistic career that has since included work on newspapers and magazines from New York to San Francisco.... His books include novels, biographies, and such vivid historical works as The Caribbean, and The French in the West Indies. (404) 
That Hughes and Bontemps had communication with Roberts is clear from the note included with his poems: "reprinted by permission of Walter Adolphe Roberts." Nine of his poems are featured, more than almost any other poet in the entire anthology, save for Hughes and Bontemps themselves, Claude McKay, and Countee Cullen. The poems include "Boyhood Etchings," about the natural sounds, scents, and images that permeate life in the Caribbean. The first stanza of the poem, in a section entitled "Tropic Sunset," exemplifies the focus of the poem.

Oh full and soft upon the orange trees

Flamed forth bright beams of glory from the West!

And through the boughs there sighed a gypsy breeze,

Bearing a thousand perfumes on its breast. (lines 1-4)

The last stanza, the end of a poem section entitled "Tropic Storm," focuses on the same topic, even though the tone is quite different.

But now a sullen murmur breaks the calm, The gathering East wind stirs the vapors warm, The roll of thunder smites upon the ear, The lightning flashes red-and bursts the storm. (lines 21-24)

Also included are "The Captains," a poem about the streets of Jamaica's harbor towns mourning the loss of the ship captains who used to circulate through them, and "San Francisco," in which the speaker dreams backward about a visit to the Bay City he describes in romantic terms.

\section{I found a woman city}

Suave as a cooing dove

I sought her as a lover,

But was too young for love. (lines 9-12)

"Villanelle of Washington Square" is a romantic reflection on the vibrancy and beauty of this New York City park: "Jasmines are in her arms and clouded quite / with lilac is the nimbus of her hair / the starshine on the Arch is silver white" (lines 6-9). "Villanelle of the Living Pan," in its very first line, avows that "Pan is not dead, but sleeping in the brake" (line 1). "Peacocks" says of the birds "they came from Persia to the Sacred Way / and rode in Pompey's triumph, side by side / with odalisques and 
idols, plumes flung wide / A flame of gems in the chill Roman day" (lines 1-4). "Vieux Carre"" praises the cultural, historical, and aesthetic richness of New Orleans (the French Quarter in particular): “This city is the child of France and Spain" (line 1) and "The braided iron of the balconies / is like locked hands, fastidiously set / to bar the world. But the proud mysteries / showed me a glamour I may not forget / Your face camellia-white upon the stair / framed in the midnight thicket of your hair" (lines 9-14).

The only poem by Roberts in Poetry of the Negro that centers on a definitively Black subject is "The Maroon Girl." The perspective is that of a spectator: "Of flesh the hue of cinnamon. The clean / Blood of the hunted, vanished Arawak / Flows in her veins with blood of white and black. ... / She is Jamaica poised against attack" (lines 3-5, 8). He names her "the Maroon girl," emphasizing her ties to the cimarron African communities of the island. Roberts makes her multiracial, reflecting one thread in the island's protonational discourse reflected in the national motto Jamaica adopted at independence, "Out of Many, One People." This reification of the mixed-race figure as the symbol of the nation mirrors the thinking of the individual who is the focus of the other Roberts poem included in Poetry of the Negro-José Martí. In "On a Monument to Marti" Roberts represents Cuba as a brown woman and Martí as her savior: "Cuba, disheveled, naked to the waist / Springs up erect for the dark earth and screams / Her joy in liberty. The metal gleams / where her chains broke. Magnificent her haste / To charge into battle and to taste / Revenge on the oppressor. Thus she seems / But she were powerless without the dreams / Of him who stands above, unsmiling, chaste" (lines 1-8). Roberts emphasizes the messianic vision; the second stanza actually includes the words "he died to make her free" (line 12).

H. D. Carberry's "I Shall Remember" posits a vision of a Jamaica that is distinguished and defined by the voices of Black and brown workingclass folk. The speaker in "I Shall Remember" is an emigrant-to-be imagining the details he will recall about Jamaica once he leaves. He goes on to anticipate remembering the people of the island and contrasting them with those in his new country, saying,

And in strange cities

Among unaccustomed people

Who move pale faced with tired staring eyes

I shall remember

The warmth and gaiety of my people 
The polyglot colour and variety of their faces,

The happy fusion of our myriad races

In the common love that unites and binds us to this land. (lines $35-42)$

He presents "fusion" and "common love" as the glue that connects Jamaicans to each other and to the island, contrasting it with the people in his destination land who "move pale faced." He goes further by specifically positioning the darker and poorer people as the most valuable aspect of the island for him. He says he shall "yearn" for "faces black and bronzed," "people with dark sparkling eyes / With ready tongue / And laughter loud and unashamed" (lines 43-47). The reference to the "ready tongue" and "laughter loud and unashamed" indexes the working classes criticized by the middle and upper classes (as well as those aspiring to be such) for being uncouth and lacking in decorum.

The most strident politically focused poems in the section are from McKay (including "If We Must Die" and "White Houses"), but even they do not explicitly specify their object/subject as a racialized or Black one. Even Una Marson, the creator of the Caribbean Voices program on the $\mathrm{BBC}$, whose affiliations with a number of race-specific organizations are indexed in her biographical note, is not represented via angry, explicitly radical, and/or race-focused poems.

By including poems by these poets about such a wide range of topics, Hughes and Bontemps argue that the Caribbean section, to truly represent the region, cannot be exclusively or primarily about race. For these editors it has to explore as many aspects of Caribbean literature, life, and intellectual and political discourse as the editors could fit-poets' relationships to the colonial mother country, engagements with socioeconomic class differences, references to nature as fact or metaphor, choices about whether and how to use traditional English poetic form and/or meter, and perceptions of the significance of the color, race, or ethnicity of the islands' people.

\section{White Creole Jamaicans in Poetry of the Negro}

Hughes and Bontemps also include Jamaican poets whose biographies suggest that they would not be classified as Negro in the United States and whose poetry does not treat the Negro experience in any way. The 
first author in the Caribbean section, and in the Jamaican subsection that begins it, is (Barbara) Stephanie Ormsby. The biographical note on her reads: "educated at Colonial High School in Kingston and at Whitelands College, Putney, England. She has been writing poetry since childhood" (403). There are a number of pieces of information, even in this brief biography, that index her class position and her ancestry, especially her attending one of the most prestigious high schools on the island as well as one in England. Whether Hughes and Bontemps are aware of or interested in, or think their readership might be aware of or interested in, the class and racial codes embedded in this poet's biography is not clear, though.

Hughes and Bontemps's inclusion of Ormsby indicates, however, that they intended her presence to advance, or at least relate to, their stated focus on the "poetry of the Negro." Hughes and Bontemps present one poem by Ormsby, "The Caribbean" (309). ${ }^{32}$ In two quatrains, it seeks to encapsulate key aspects of the region's history, including brutal piracy and a sea that carries the region's history within it. Ormbsy writes, "Here where the pirate chieftains sailed / in quest of gore and gold" (lines 1-2) and "The white foam flashes as of yore / and melts in pearls and tears" (lines 7-8). The poem portrays nature and the sea as not only timeless but also supreme to humans and their quests and might. Despite the pirate chieftains, their quest, and brutal, bloody might, the "white foam" still "flashes as of yore," not countenancing or remembering them at all. Ormsby's choice of form and meter also hints at a notable degree of affinity for traditional English models. ${ }^{33}$

Tom Redcam (the pen name of Thomas MacDermot) is the second Caribbean poet presented in the section. Hughes and Bontemps's biographical note on him says that he was "educated at Falmouth Academy and at the Church of England Grammar School at Kingston. He started his career as a schoolmaster and gradually moved into journalism and literature. His patriotic songs have earned him a high place in the esteem of the island where his countrymen sometimes called him 'The Uncrowned Laureate of Jamaica"' (404).

Hughes and Bontemps include one poem by Tom Redcam entitled "San Gloria." It, like Ormsby's "The Caribbean," foregrounds the extent to which history is embedded in the natural features of the region. The poem is addressed to the "Captain of the wide western seas" and asks him whether he remembers the region's "spice-'censed breeze," and the "still flowering gyneps" that "tempt the bees" (pp. 309-10, lines 1, 3, 16). 
The "Captain" appears to be Christopher Columbus, ${ }^{34}$ but the poem neither praises nor decries his actions in the region. Instead, it foregrounds the power of the region's seas, sounds, sights, and scents, and the indelible imprint that they have likely left on Columbus, wherever he is these many centuries later. The islands, their sea, their flora, and their fauna are almost personified. They engage, respond to, and interact with each other as well as with the captain's ship and soul. In the lines "White-sanded curves where serried trees / Filed backward as thy sharpened prow / Sheared into foam the racing seas" (lines 4-6) we see the sea responding to Columbus's ship. In the next few stanzas, though, man becomes progressively less relevant, and timeless nature continues on whether or not he is present: "San Gloria's wood-carved mountain frieze / In the blue bay is mirrored now / As when thy white sail wooed the breeze" (lines 7-9), "The thunder of insurgent seas / Beats yet the rough reef's ragged brow / Roaring by green, far-stretching leas" (lines 10-12), and "Yet through the wood the peony flees / and frets with gold the night-dark bough / down the long avenue of trees" (lines 13-15).

The biographical note on Agnes Maxwell Hall, the third Jamaican poet included in Poetry of the Negro, describes her as

educated in London, Boston, and in New York City, where she studied short-story writing at Columbia University. Her stories and poems have appeared in little magazines in the United States and England. She owns and operates a dairy in the Jamaica mountains at Kempshot, the site of the observatory of her father, the late Maxwell Hall, F.R.A.S., F.R.M. et S. (402)

As with Ormsby and Tom Redcam, there are indicators here of Maxwell Hall's ancestry and class position..$^{35}$ They include the facts that her father owned an observatory, and that he was a Fellow of the Royal Astronomical Society. Also significant is the fact that her family dairy has a name.

The two poems by Maxwell Hall included in Poetry of the Negro, "Jamaica Market" and "Lizard," are both centered on the flora and fauna of the island. "Jamaica Market" is a creative cataloging of the names of Jamaican fruits, vegetables, spices, and other items typically found in one of the island's outdoor markets (thirty-eight items total). ${ }^{36}$ It begins "Honey, pepper, leaf-green limes / Pagan fruit whose names are rhymes" (lines 1-3). The poem's meter and the absence of any full stops until the end of the final line forces the reader to hear the rhythm of the words 
and, by implication, of the market and the island. This is, and is intended to be, a profoundly Jamaican poem, one that encapsulates Jamaican life through specific words, images, and rhythms. ${ }^{37}$ The structure of the poem - the virtually undisrupted cataloging and the use of distinctively Jamaican words for particular fruits and vegetables-ensures that it will transport any Jamaican reader who has ever visited the market on a Saturday, back there. He or she will recall the specific sights, sounds, and scents. The poem ends by referencing the skin color of the people at the market: "Black skins, babel-and the sun / That burns all colours into one" (lines 17-18). These final lines, a rhyming couplet, also indicate that, for the speaker, the market is a synecdoche for the country-the one into which all colours are burned.

The poem is written from the perspective of an observer, not that of a participant in the market, and these last lines, in which the people are mentioned, signal this distance. The market participants only appear through the synecdoche of the phrase "Black skins." Similarly, "babel" works metonymically, presenting the voices of the people in the market as an undifferentiated mass-as a cacophony.

Maxwell Hall's second poem "Lizard," written from the perspective of the lizard, contrasts with "Jamaican Market." 38 The lizard recounts its life and encourages the reader to experience it. It is not either explicitly or implicitly a political poem but rather a playful representation of one aspect of Jamaica's natural environment. The poem reads, in part,

$\mathrm{O}$, what would people say if you

Ate bitter-tasting ants, drank dew,

Caught gnats as blue as summer skies

And swallowed painted butterflies? (lines 1-4)

The poem reads as a simple nature poem. There is nothing in the poem to suggest that the lizard is a metaphor, or that the poem is intending to make any commentary on anything beyond the experience of the lizard.

This poem, and the others in the section, which are simple poems about nature or other uncontroversial aspects of Caribbean existence, such as H. D. Carberry's "Nature," demand that we ask why they are included. The issue is not simply that Hughes and Bontemps include these poems by writers who would likely be understood as White in the United States, but that Hughes and Bontemps position them as representative voices in a volume entitled The Poetry of the Negro. As we have seen, in 
a number of cases, their poems are not about "the Negro experience in the Western world," being neither about Negroes nor written by Negroes. For Hughes and Bontemps, that detail seems to matter less than the fact that they are "representative" of either the Caribbean or Caribbean poetry. It seems that, for them, a volume called The Poetry of the Negro would not be complete without the Caribbean, so they choose to include as many Caribbean writers as they can.

Both their valuing of the Caribbean and their interest in presenting the work of Caribbean writers diverge from the approaches taken by virtually all the other editors of anthologies of African American poetry during this period. These other editors see Negro poetry in exclusively national terms, and understand themselves as producing anthologies to demand recognition of African Americans' contribution to American letters, in particular, and society, more generally.

Hughes and Bontemps's inclusion of poems in the Caribbean section that are neither by nor about Negroes does contradict their own stated basis for the other two sections of the anthology—the poems must be either written by individuals classified as Negro in the United States or about Negroes. These British Creole writers were, in many ways, part of the same tradition as the Romantic poets included in the "Tributary Poems by Non-Negroes" section. ${ }^{39}$ The main difference is that they happened to be from the exotic locale about which they were writing verses full of images, sounds, scents, emotions, flora, and fauna. This is very different from Negro poets writing about their or their community's experiences, and writing to ensure that their humanity and intellectual capacity will be recognized. The question is, then, what was the significance of "the Caribbean" for Hughes and Bontemps, and what does their decision to include not just the region, but writers from the Caribbean who would be likely considered White in the United States, tell us about the definition of "poetry of the Negro" they aim to articulate through the anthology?

Perhaps the answer lies in their use of the phrase "in the predominantly Negro countries around the Caribbean" (viii) in their explanation of why they chose writers from this region "without respect either to racial implications in the verses or to the identity of the poets" (viii). This formulation suggests they felt the need to include the Caribbean in their anthology because the majority of the population is Negro. Even if neither the subjects of poetry nor the poets are Negro, the fact that the poetry was written by individuals from a predominantly Negro place 
makes it worthy of inclusion. Although at other points in the preface, Hughes and Bontemps refer to their volume as intended to present "the verse [the Negro] has written and inspired" (ix), they do not explicitly make this argument in their framing of the Caribbean section. Nevertheless, the idea that the Caribbean is a predominantly Negro space, and that anything that comes out of it is necessarily connected to Negroness in some way, does still seem to undergird their selections of poets and poems. Hughes and Bontemps allow that the Negroness of the Caribbean is inherent in the region's terrain, and they do not require that the poems they include from the region be explicitly about or by Negro people. Representations of the terrain, sights, scents, and sounds of nature, and the histories embedded therein, make poems Caribbean enough, in Hughes and Bontemps's eyes, to be included in this section.

They do also feature poems by British Creoles that are more political, and in which nature appears more clearly as a metaphor for the sociopolitical environment, though.

P. M. Sherlock's "Dinner Party 1940" dramatizes the nonchalance of the English upper class about the deaths of soldiers and civilians in the war. It reads, in part,

Do you mind the news while we eat?

So, guests assenting,

The well-bred voice from Daventry

Mingled with sounds from the pantry

..."and at

Narvik where for 5 days a storm has raged a few were killed"

More mutton Alice? Yes, it's delicious dear" (lines 1-4, 8-10)

The ubiquitous $\mathrm{BBC}$ voice permeates the air, but the content of the broadcast is sublimated to dinner-party pleasantries.

Hughes and Bontemps's commitment to presenting the political and cultural dynamics of the region is further evidenced in their presentation of Jamaican-born English Creole J. E. McFarlane's poem "On National Vanity," a critical commentary on man's drive to create nations. Among its most vital lines are "Nation on Nation follows, Sun on Sun // But we are blind and see not. In our pride / We strain toward the petrifying mound" (lines 3-5). The poem appears in The Poetry of the Negro at a moment in which Jamaicans were in the midst of deciding whether and how to demand independence. By including "On National Vanity" 
Hughes and Bontemps provide a window into a crucial element of the intellectual and political discourse on the island, and in the region, at this time. It was McFarlane who founded the Jamaica Poetry League, a branch of the Empire Poetry League in England, in 1923. It was McFarlane who had edited the very first anthology of Jamaican poetry, published in 1929. Entitled Voices from Summerland, it featured twenty-five poets, including many of the aforementioned ones that Hughes and Bontemps later end up presenting in their anthology. ${ }^{40}$ In addition to Ormsby, Roberts, McKay, Redcam, Hollar, and McFarlane himself, Voices from Summerland also offers the poetry of H. S. Bunbury who was "born at Waterford, Ireland" (McFarlane, Voices, 303), William Morrison who was "born in the parish of Grange, Banffshire Scotland" (McFarlane, Voices, 304), and Rev. John Radcliff who was "born at Slievniskie, Castlewellan, County Down, Ireland." Race is not referenced in Voices from Summerland. Birth in or identification with Jamaica is the editor's primary focus. He writes in his preface, "this anthology [is] representative of Jamaica's best thought for a generation or more" (McFarlane, Voices, n.p.).

As noted earlier, the decades between the publication of Voices from Summerland and The Poetry of the Negro marked the beginning of a crucial period in the development of Caribbean literature and national identities. Among the key questions being debated were: What is Caribbean poetry? How different is it or should it be from English poetry in areas such as form, meter, specific flora and fauna represented, and content more generally? What should be the relationship between poetry and the daily lives of everyday Caribbean people? Many of the Jamaican writers presented in The Poetry of the Negro were deeply involved in these debates, often through their poetry as well as through the organizations and activities in which they chose to be involved. Stephanie Ormsby, for example, participated in the Empire and Jamaica poetry leagues, presenting poems there as early as October $26,1926 .{ }^{41}$ This moment also saw increased access for Afro-Caribbean young people to educational and cultural institutions in "the mother country." Caribbean Voices, the pioneering $\mathrm{BBC}$ radio program that gave many Caribbean writers their first opportunity to share their work with the world beyond their islands, was created by Una Marson, among others, in $1946 .{ }^{42}$ Caribbean writers and artists also began to create their own publication outlets in the region. Among these were the journal Bim created in 1942 by Frank Collymore of Barbados, Kyk Over Al founded in 1945 by A. J. Seymour in British Guiana, and Focus (1943) edited by Edna Manley in Jamaica. 
The questioning and concern with self-determination displayed by these Caribbean writers and artists was driven by material conditions on the ground, most particularly the dire economic conditions brought about by the Great Depression and the diminishing of work opportunities in Latin America. ${ }^{43}$ The result was conflict between colonial policies and workers' demands for rights, fair wages, and a voice in shaping their futures. Writers and artists concerned about the situation posited new aesthetics and approaches to crafting and disseminating their work, which had sought to engage and reflect the voices and perspectives of the sufferers. The rise of Focus, for example, as Laurence Breiner has described it, "introduced a new Jamaican poetry of protest and social consciousness" not always well received by traditionalists. ${ }^{44}$ Of the new writers, McFarlane notes with regret, "Jamaica is becoming active and articulate" (Breiner, 63). He notes that "something of great value has been lost to the modern Jamaican" and longs for "the faith of Tom Redcam and of Bunbury ... the joy of Constance Hollar," which from his perspective are "positive qualities making for the stability and direction of the life of the community" (Breiner, 64). Donnell and Welsh describe him as promoting "a version of poetry in which Anglocentric canonical criteria and texts remain unchallenged." ${ }^{45}$

Hughes and Bontemps were certainly aware of these happenings. Hughes actually writes to Bontemps about Bim: "The magazine, B.I.M., volume III, No. 9, just arrived. It is published in Barbados, and I think you ought to have it for your collection." ${ }^{46}$ They were clearly in contact with Caribbean writers and communities during this period. In the same letter in which he mentions Bim, Hughes also lets Bontemps know about the availability of Collymore's volume Flotsam: Poems 1942-1948. Other letters between the two editors about the Caribbean include one from October 18, 1947, in which Hughes informs Bontemps about his experiences in Jamaica: "this is a wonderful island-where everybody talks Ja-MAI-can!" (Nichols, 226) and another from May 11, 1948, in which Hughes tells Bontemps, "The West Indians got all your books and were highly pleased." ${ }^{47}$ Also, on September 8, 1949, Bontemps writes to Hughes about the visit by Trinidadian writer Harold Talemaque to New York. ${ }^{48}$

These two editor-poets were also aware of the racial complexities at work as these questions about national, aesthetic/literary, and cultural identity were being worked out. A letter that Hughes writes to Bontemps on August 21, 1948, as they are thinking about the best way to craft their preface to the volume, reflects this fact. He says, "It should be made clear 
(for the sake of the critics and also for the comfort of the West Indianswhom one drop of white blood makes white, and not the other way around as it is here) that we have drawn no color line in our anthology, using the work of all poets who write even obliquely on Negro themes, peoples, or lands." ${ }^{49}$

\section{Reappraising The Poetry of the Negro in Context}

The Caribbean is only present in most of the anthologies of "Negro poetry" produced during this period via the inclusion of Claude McKay. James Weldon Johnson includes the aforementioned preface comparing the relative access to the "national spirit" of U.S. Blacks and "Aframericans" in Latin America and the Caribbean, in addition to including one other Caribbean poet in the Book of American Negro Poetry. That poet, George Margetson, also appears in White and Jackson's Anthology of Verse by American Negroes.

The only anthology editor during this period who approximates Hughes and Bontemps's feat is Beatrice Murphy, editor of the aforementioned Ebony Rhythms and Negro Voices. In Negro Voices, she includes a Jamaican poet named Lloyd G. Oxley who does not appear in either The Poetry of the Negro or Voices from Summerland. Oxley, she tells her readers, was "educated at St. George's College and Saint Mungo's in Glasgow, Scotland" in addition to being "the founder of the Colored Poetic League of the World and is at present engaged in research work of Negro literature in foreign countries." 50 "Death Sows a Seed" and "The Suttee" are the two poems of his that she presents. Ebony Rhythms includes three Caribbean-descended poets. ${ }^{51}$ The poems of Samuel Haynes, "a native of Belize, British Honduras," who "is copy editor of the Afro-American Newspapers Inc., in Baltimore" and "was former confidential secretary and personal representative of the late Marcus Garvey" are undoubtedly and explicitly racial and political in orientation. His poem "Warning" begins with the lines "Listen white man / Listen well" (Murphy, Ebony Rhythms, pp. 1-2, lines 50-51), leaving no doubt about the speaker's perspective. The other Caribbean poets in Ebony Rhythms are Edward Richards, who "was born in Saint Thomas, Virgin Islands" and whose "poetry has appeared in the Afro-American, The People's Voice and other publications" and Edna L. Harrison, "a native of Boston Massachusetts" who "is of British West Indian parentage" (Murphy, Ebony Rhythms, 125, 79). 
The value of The Poetry of the Negro lies in its bringing together the voices of Negroes themselves, with those who are looking at them, in many cases from a distance, with those who have grown up in a context defined in intangible ways by their presence. The Poetry of the Negro juxtaposes (or reflects the real-world juxtaposition of) the Negro's own uses of poetry as a mode of self-expression and/or as a political intervention, White Americans' and Europeans' attempts to use poetry to represent the feelings and thoughts that looking at the Negro stirred up within them, and Caribbean writers' willingness and/or ability to speak to, from, and/ or about the experiences of the majority population of their region..$^{52}$

In light of our current interest in the Black Atlantic, diaspora, and transnational blackness, an appraisal of the specific ways editors of anthologies of Black literature envision, enact, belie, or reject the persistence of prevalent notions about the geographies and locations of Black literature is particularly useful. It will provide insight into a range of definitions of blackness, perceptions about whether and how literature can be a tool used to change the material conditions of Black people locally and globally, and of the role of Whites in that process.

Notes

1. Langston Hughes, "The Negro Artist and the Racial Mountain," in Angelyn Mitchell, Within the Circle: An Anthology of African American Literary Criticism from the Harlem Renaissance to the Present (Durham: Duke University Press, 1994), 59.

2. As exemplified by Du Bois's "Criteria of Negro Art" (1926), reprinted in Mitchell, Within the Circle, 60-68; Sterling Brown's "Our Literary Audience" (1930), reprinted in Mitchell, 69-78; Richard Wright's "Blueprint for Negro Writing" (1937), reprinted in Mitchell, 97-106; and J. Saunders Redding's "American Negro Literature" (1949), reprinted in Mitchell, 107-16.

3. Langston Hughes and Arna Bontemps, eds., The Poetry of the Negro, 1746-1949 (Garden City, NY: Doubleday, 1949). Quotations from this edition will be cited parenthetically. A much revised later version of the anthology (also briefly discussed in this essay) was published by Doubleday in 1970.

4. "Ogden Nash Verse Is Added to Public Library Shelves," The Star (Chicago) March 18, 1949, 13.

5. Martin, Gertrude, "January Hughes' Month of Books," Chicago Defender, January $15,1949$.

6. "30o years of Negro Poetry Bound in Doubleday Collection," Kingsport Times, January 16, 1949.

7. Eleanor Roosevelt, Review of The Poetry of the Negro, 1746-1949, by Langston Hughes and Arna Bontemps, eds., El Paso Herald Post, January 14, 1949, 3. 
8. Kirkus 16:609, Review of The Poetry of the Negro, 1746-1949, by Langston Hughes and Arna Bontemps, eds., November 15, 1948; Book Review Digest, 1949, 441.

9. John Lovell, "Hughes, Langston and Bontemps, Arna (eds.) The Poetry of the Negro: 1746-1949," Journal of Negro Education 19, no. 1 (Winter 1950): 67.

10. Lovell, 67 .

11. Roosevelt, 3 .

12. Hubert Creekmore, “Two Rewarding Volumes of Verse," New York Times, January $30,1949$.

13. John Frederick Nims, "Inclusive Anthology of Negro Poetry," Chicago Tribune, January 30, 1949, B4.

14. Nims, B4.

15. Review of The Poetry of the Negro, 1746-1949, The Tiger's Eye, March 15, 1949.

16. "Weekly Book Review," New York Herald Tribune, January 16, 1949, 17.

17. For the purposes of this essay, I focus primarily on poetry anthologies.

18. Although not an anthology, Dorothy B. Porter's North American Negro Poets: A Bibliographical Checklist of Their Writings, 1760-1944 (Hattiesburg, MS: The Book Farm, 1945) is a noteworthy example of the ways in which African American writers used anthologies during this period as a way to intervene in, interrogate, and contradict the prevailing narratives about African Americans' rights, capabilities, and identities. It is based on Arthur A. Schomburg's 1916 bibliography that included two hundred and thirty-six titles. As is evident in his Bibliographical Checklist of American Negro Poetry (New York: Charles F. Heartman, 1916), Schomburg's definition of "American Negro Poetry" includes poetry by people of African descent from the United States and other nations across the Americas, including Cuba's Gabriel de a Concepción Valdes (aka Plácido), Haiti's Justin Therison, Puerto Rico's Gonzalo Marin, and Martinique's Leon Laviaux. Porter expands Schomburg's checklist by doubling the number of U.S. titles but reduces the number of writers from the other Americas by choosing to include only those "West Indian writers who have lived an appreciable time in the United States or who have had their works published here in the English Language" (n.p.). In editing this bibliography she aims to intervene into contemporaneous debates over the definitions and parameters of "Negro poetry." She states explicitly that the "olden question" "'is poetry racial?" is not a valid objection to the usefulness of a bibliography of Negro poetry such as hers or Schomburg's because "it has been shown that a poem can be racial in content while remaining poetic in form" (n.p.). Her bibliography is intended for "those who may wish to study the facets of race consciousness in Negro expression as well as the aesthetic factors" (n.p.).

19. V. F. Calverton, editor of the 1929 Anthology of American Negro Literature (1929; reprint, New York: Modern Library, 1976), traces the genealogy of "Negro literature" all the way back to ancient Africa. He notes that "in the Songhay empire ... education was advanced to such a point that people came from all over the Islamic world to teach in its schools" (1), and further that "throughout the Sudan ... university life was fairly extensive" (1). Delineating this genealogy serves two related functions, in Calverton's eyes-helping Americans "understand [the Negro's] achievement in American art and literature in terms of environmental evolution," undercutting the idea that "every Negro genius is a product of White miscegenation" (2), and treating "the growth of the new Negro literature as a fad" (3). He goes on to argue that the Negro has been a vital and constitutive element of the nation's culture: "The contributions of the Negro 
to American culture are as indigenous to our soil as the legendary cowboy or goldseeking frontiersman" (3). Calverton goes one step further, though, arguing that the Negro has done more to define and distinguish American culture than the White man: "The Negro . . has developed out of the American milieu a form of expression, a mood, a literary genre, a folk-tradition, that are distinctly and undeniably American. This is more than the White man has done" (4).

Also particularly notable is the massive 1,081-page anthology edited by Sterling Brown, Arthur P. Davis, and Ulysses Lee, The Negro Caravan: Writing by American Negroes (New York: Dryden Press, 1941). It was intended: “(1) to present a body of artistically valid writings by American Negro authors, (2) to present a truthful mosaic of Negro character and experience in America, and (3) to collect in one volume certain key literary works that have greatly influenced the thinking of American Negroes, and to a lesser degree, that of Americans as a whole" (v). Their work differs from and expands on the existing range of anthologies by presenting multiple genres, paying significant attention to the "numerous and influential writers of the nineteenth century," and including new writing by Langston Hughes, Zora Neale Hurston, and Charles Johnson, among others. The anthology includes a unique section of "folk literature" that includes spirituals, slave seculars, aphorisms and ballads, work songs and social songs, social protest songs, blues, folktales, and folk sermons.

Although the focus of this essay, in general, and this section, in particular, is anthologies of poetry, I include Negro Caravan in this note because of its size and significance as well as because of the thought-provoking statements the editors make in their introduction about the existence or validity of the term Negro literature. They "do not believe that the expression 'Negro literature' is an accurate one and ... have avoided using it" because "writings by Negroes do not seem to the editors to fall into a unique cultural pattern. Negro writers have adopted the literary traditions that seemed useful for their purposes" (6). They state clearly, "the editors consider Negro writers to be American writers, and literature by American Negroes to be a segment of American literature" (7). They reject the term Negro literature, saying, "The next step is a double standard of judgment . . . 'a Negro novel,' thought of as a separate form, is too often condoned as 'good enough for a Negro"' (7).

20. Robert Kerlin, Negro Poets and Their Poems, 1st ed. (Washington, DC: Associated Press, 1923), n.p.

21. Like Kerlin, Newman Ivey White and Walter Clinton Jackson, editors of $A n$ Anthology of Verse by American Negroes (Durham, NC: Trinity College Press,1924), highlight the growth and quality of Black poetry over the centuries. Their introduction is a tremendously detailed history of Negro poetry beginning with Jupiter Hammon's broadside, and it includes a number of writers rarely mentioned even today. White and Jackson also decry White American society's ignoring of poetic production by Blacks.

22. Countee Cullen, "Foreword," in Countee Cullen, ed., Caroling Dusk: An Anthology of Verse by Negro Poets (New York: Harper and Bros., 1927), xi.

23. Cullen, 11 .

24. Beatrice M. Murphy, Negro Voices: An Anthology of Contemporary Verse (New York: Henry Harrison, 1938), n.p.

25. James Weldon Johnson, "Preface," in James Weldon Johnson, ed., The Book of American Negro Poetry (New York: Harcourt, 1922), 47.

26. Johnson, "Preface," 47. 
27. Johnson, "Preface," 40.

28. Hughes's affinity for Whitman's work has been well documented by scholars.

29. Nancy Cunard's Negro: An Anthology (London: Wishart, 1934) is worth mentioning here because it presents such a comprehensive picture of Black literature, experience, and intellectual as well as political thought. It parallels Poetry of the Negro in its presentation of work by Whites as well as by people of African descent from around the world. It is intended, Cunard avers, "for the recording of the struggles and the persecutions and the revolts against them, of the Negro peoples" (xxxi).

30. Including African Gold Coast poet Aquah Laluah, presented under the heading "Africa."

31. Without DNA evidence or other evidence that these writers ever entered the United States or were ever officially assigned to a racial category in the United States, it is impossible to prove that this statement is unassailably accurate. It is possible, however, to identify the national origins of their parents, the circles in which they moved in Jamaica, and the affinities they expressed in their words and actions.

32. They note that the poem is included "by permission of the author," suggesting that they had some form of communication or correspondence with Ormsby.

33. A review of Jamaica Gleaner issues from 1920 to 1950 reveals that Ormsby was a regular participant and occasional winner of the island's poetry competitions. In 1926 she presented her poem "The Poet" at the prestigious Empire Poetry League meeting. In 1930, her poem "Castle in Spain" was among those "highly recommended" by the judges in the Jamaica Gleaner Christmas competition for poetry. In 1934, Ormsby actually wins second prize in the Christmas Competition with her poem "Summer Moon." The announcement describes "that fine artist Stephanie Ormsby, whose 'Summer Moon' is an excellent example of her ability to get her effects with a minimum of effort" (Jamaica Gleaner, December 22, 1934, 25). Lines from the poem include, "There was a fawn that peered at me / Behind the bale of a wayside tree" (1-2). In contrast with the poems presented in the Gleaner, the poems by her included in Poetry of the Negro focus explicitly on Caribbean rather than European flora and fauna.

34. Martin Banham and Errol Hill, eds., The Cambridge Guide to African and Caribbean Theatre (Cambridge: Cambridge University Press, 1994), 147.

35. I am less interested in the fact of Maxwell Hall's White/European ancestry than I am in how Hughes and Bontemps present these writers, and how they handle the markers of class and race implicit in the writers' biographies/life histories. Were Hughes and Bontemps reading these writers as White, but turning a blind eye to their race because they were from the Caribbean, a space they view as fundamentally Negro? Or did they not know that most of these writers would have been seen as White in both the United States and Jamaica?

36. I, along with my classmates at primary school in Jamaica, had to memorize and recite this poem quite frequently.

37. It was even the basis of the 1 st and 3 rd prize winning entries in the Jamaica Broadcasting Corporation's National Song competition in 1968.

38. This poem appeared in the 1942 Jamaica Poetry League Yearbook and was featured in the October edition of Caribbean Voices-the BBC radio program. Maxwell Hall was a well-known figure on the Jamaican literary scene well before then. In 1935, for example, her poem "Zanzibar" was "highly commended" by the judges in the Jamaica Gleaner Christmas competition. Lines include: "In Zanzibar-in Zanzibar / 
striped zebras wash the town / date palms throw patterns on the street / where slaves come marching down / From dust-blue mountains far away" (lines 1-5). Her poem "Tropic Garden" was similarly recognized in 1936. It features the lines, "At dawn there is the silence of the lilies / and the beat of the drums / Red drums that sound wild glory for the Ackee trees / and scatter yellow jasmine stems upon the grass / at noon I hear the bright green cymbals of the lotus leaves / and clanging golden tongues of hibiscus" (lines 1-6).

Importantly, Miss Maxwell Hall was also active in the movement to help England, "the mother country," financially during World War II. She sat on the "Buckingham at Mt. Horus Committee," a group created by the concerned residents of St. James parish (Jamaica) who convened in October 1939 to help England "with the current crisis there." Of the meeting the newspaper reported "enthusiasm ran high as speaker after speaker outlined schemes he had evolved by which each and every one could help in his own way to ensure victory for the Mother Country and her allies" (Jamaica Gleaner, October 12, 1939, 15).

39. Agnes Maxwell Hall, for example, repeatedly introduced new or forgotten English poems to the Jamaica Gleaner's editorial-page readers through letters to the editor. The poems included Sir Henry Newbolt's poem “Drake's Drum” (September 7, 1940, 42) and Francis Thompson's poem about a cricket match between English teams Lancashire and Gloucestershire (October 5, 1947, 6).

40. J. E. McFarlane, Voices From Summerland: An Anthology of American Poetry. (London: Fowler Wright, 1929).

41. Jamaica Gleaner, October 26, 1926, 4.

42. John Figueroa has edited a collection of poetry, based on his in-depth review and selection of scripts from the program. It features a moving foreword by Philip Sherlock. See Caribbean Voices: Dreams and Visions (London: Evans Brothers Limited, 1971).

43. Alison Donnell and Sarah Lawson Welsh, eds., The Routledge Reader in Caribbean Literature (London: Routledge, 1996), 107.

44. Laurence A. Breiner, An Introduction to West Indian Poetry (Cambridge: Cambridge University Press, 1998), 66.

45. Donnell and Welsh, 110.

46. Langston Hughes to Arna Bontemps, January 15, 1949, Arna Bontemps Papers, Box 8, Folder 5, Special Collections Archive, Franklin Library, Fisk University.

47. Charles H. Nichols, ed., Arna Bontemps-Langston Hughes Letters, 1925-1967 (New York: Dodd, Mead, 1980), 226, 234.

48. Nichols, 264.

49. Hughes to Bontemps, August 21, 1949, in Nichols, 235.

50. Murphy, Negro Voices, 119.

51. Beatrice M. Murphy, Ebony Rhythm: An Anthology of Contemporary Negro Verse (New York: Exposition Press, 1948). This is in addition to poets born in Mexico, the Philippines, Haiti, Puerto Rico, and Liberia.

52. In compiling the 1970 edition, Bontemps excises the Caribbean section completely, along with any references to it or the fungibility of "racial yardsticks" that were present in the initial edition. Arna Bontemps and Langston Hughes, eds., The Poetry of the Negro (2nd ed., New York: Doubleday, 1970). 
William J. Maxwell

\section{EDITORIAL FEDERALISM}

\section{The Hoover Raids, the New Negro Renaissance, and the Origins of FBI Literary Surveillance}

Thanks to disclosures forced by the U.S. Freedom of Information Act (FOIA), we now can see that the Federal Bureau of Investigation (FBI) kept an eye peeled on the Harlem Renaissance. And that it trained on the builders of this movement, the laboratory of Afro-modernism, its legendary system for archiving and exploiting the results of intelligence work. Gwendolyn Bennett, Sterling Brown, W. E. B. Du Bois, Langston Hughes, Georgia Douglas Johnson, Alain Locke, Claude McKay, Louise Thompson Patterson, J. A. Rogers, George Schuyler, Walter White: all were favored with FBI files, the nation's highest medal of radical honor, some thin (Douglas Johnson's is all of 6 sheets) and some as thick as windy literary biographies (Du Bois's scales 756 pages). While the $\mathrm{Bu}-$ reau's voguish interest in Harlem's New Negroes faded with the Great Depression, its inspection of Afro-modernist writing persisted from World War II through the Black Arts Movement formally declared in 1965. In the early 1940s, the FBI began compiling dossiers on such traveling targets as Lloyd Brown, Chester Himes, John O. Killens, Richard Wright, and early Barack Obama mentor Frank Marshall Davis. In the depths of the Cold War, unsurprisingly a busy season of FBI ghostreading, no fewer than twenty-two African American literary intellectuals were first tracked by Bureau paperwork, among them Alice Childress, Harold Cruse, Ralph Ellison, Lorraine Hansberry, Bob Kaufman, Willard Motley, and William Gardner Smith. Three Cold War files created in the 1950s-James Baldwin's, Amiri Baraka's, and Hoyt Fuller's-look forward to the last great wave of FBI book-clubbing, an elaborate counterintelligence program to outwrite the Black Arts Movement drawing from dossiers on Addison Gayle Jr., Larry Neal, Dudley Randall, Sherley 
Anne Williams - and likely many more. FOIA rules sanely stipulate that third-party historians may examine copies of personal FBI files only after their subjects' deaths. Absent self-requests made public by living Black Arts veterans (Baraka's file, self-deposited at the Moorland-Spingarn Research Center at Howard University, is one), we can only guess at the existence of dossiers on Ed Bullins, Nikki Giovanni, Haki Madhubuti, and the rest. When the full tally is accessible, it will shock and awe if Bureau "filing" of Black Arts writers did not top the presently documented zenith of the Cold War nadir.

Not everything, then, can yet be known about the FBI's half-century of spying on black authorship, an institutionalized passion stretching from the heat of the Red Summer to J. Edgar Hoover's death in the Bureau saddle just weeks before the Watergate break-in. Especially unhelpful in the search for knowledge is the recent destruction of Margaret Walker's file and other irreplaceable historical records under a misnamed federal Records Retention Plan. ${ }^{1}$ For all this, a number of meaningful conclusions about the collision of black letters and Bureau surveillance can already be reached. My 101 FOIA requests, supplemented by the detective work of prior researchers, reveal that the Washington, D.C., national headquarters of the FBI opened a minimum of forty-seven files on individual African American authors and critics active during the Hoover years, 1919 to 1972 . Comprising more than 13,000 pages in all, the sheer bulk of these files outweighs the Bureau's assurances that it hatched no dedicated programs of reader response. Taken together, the contents of the forty-seven files demonstrate that modern African American writing repeatedly excited high-strung state scrutiny, a by-product of the New Negro Renaissance that ranged into the "Renaissance II" of the Black Arts Movement.

According to the Bureau's own declassified word, Hoover and lesser FBI ghostreaders pored over scores of Afro-modernist poems, plays, essays, stories, novels, reviews, treatises, and transcribed table talk-some even before publication with the aid of bookish informers at magazines and publishing firms. Scandalously, the files reveal that the FBI readied preventive arrests of more than half of the black authors shadowed in its archive. Twenty-six of forty-seven, to be exact, were caught in the invisible dragnet of the Bureau's "Custodial Detention" index and its successors, hot lists of pre-captives "whose presence at liberty in this country in time of war or national emergency," Hoover resolved, "would be dangerous to the public peace and the safety of the United States Government." By the 
time of the Panthers and Black Power, Hoover's literary G-Men were indeed sufficiently versed to produce an Afro-modernism of their own, an eccentric style of state minstrelsy bent to classic counterintelligence purposes of simulation, infiltration, and plausibly deniable manipulation. ${ }^{3}$ The early and creative intensity of the Bureau's watch on black literature has been unknowingly minimized, the files collectively suggest, both in literary studies and in historical exposés harnessing FOIA requests to uncover either the Bureau's "war on words" or its "secret file on black America," parallel tracks that should acknowledge their underground crossings. ${ }^{4}$ The backdating and thick description of Bureau surveillance of legal dissent, a muckraking preoccupation since Hoover's passing, is thus due for extension into the field of African American literary history.

Which impulses and investments led to the FBI's worried fascination with black letters? Why was the Bureau first among publicly funded institutions of literary study in treating Afro-modernist writing as no ineffectual fad? This chapter aims to answer these questions by sifting through the remains of the meeting of young J. Edgar Hoover, the first American Red Scare, and the dawning of the New Negro Renaissance. Hoover's Bureau, I will document, arrived early at a practice of "editorial federalism" calculated to win friendly readers and influence errant authors at all stages of the textual life cycle. Here, if nowhere else, Addison Gayle Jr.'s figure of the "invisible censor, white power," assumed substantial form, incarnating the black writer's racialized self-doubt as a looming federal interloper, a state spook who sat beside the creative "sanctuary of [the] private room." Examining the origins of FBI editorial federalism is thus one means of illuminating the broad, color-coded "social dimension that informs the particular exchanges involved in [the] textual production" of African American literature. ${ }^{6}$ It is also a means of suggesting that recent editorial theory should enlarge its anti-Romantic concept of socialized authorship to entail the Hooverite figure of the federal editor-a figure socialized to represent the national security state's collective interests in the transindividual network of literary creation.

\section{Hoover in the Hoover Raids: The Librarian's Red Scare}

"Wanted. A servant at 413 Seward Square." So reads an item in J. Edgar Hoover's earliest surviving literary production, a two-page neighborhood newspaper from 1906 that the eleven-year-old reported and 
published on his own. Apart from advertising the Hoover family's comfortable place in the federally employed D.C. middle class, the Weekly Review hints at several of J. Edgar's lasting rhetorical preferences. These include the proverbial saw ("Where there is a will, there is a way"); the prescriptive guide to better health and blameless appearance ("Eat slowly. Don't eat adulterated food. Don't eat too much. Don't eat between meals. Clean your teeth."); and the case study of disaster bravely averted ("Escaped from death. On Friday, about 12:15 o'clock, Mrs. Hoover, of 413 Seward Square, S.E. came near to losing her life. She was frying some eggs for lunch, and the blaze caught to her back. ...") (Powers, 20). From the standpoint of the Bureau's historic entanglement with Afro-modernist literature, the most revealing item arrives at the end of a feature on the bicentennial of Benjamin Franklin, the American thinker-tinker whose Autobiography (1793) shines through Hoover's maxims on the virtues of will and steady chewing. "Franklin's two-hundredth anniversary was celebrated on Wednesday last," notes the Bureau director-to-be (21). "At the Library [of Congress] there were books which he has printed, papers written by him, and the Declaration of Independence, signed by him" (21).

Both the Franklin plan of textual governance and the archival muscle that exhibited it impressed Hoover's literary education and molded the operation of his FBI. Within this document-squirreling police bureaucracy, the last word of the director's signature was preceded by binding marginalia in distinctive blue ink and augmented by a torrent of books, files, leaflets, manuals, articles, index cards, press releases, top-secret reports, and mass-market hype vetted, bylined, or authored by the agent/ editor-in-chief. Bureau operations, observes William H. Epstein, consisted "primarily of a huge catalogue of words." Redrafted by Hoover, the foundational model of the FBI writer-director mushroomed into a thoroughgoing literarization, strategic and obsessive, of federal police administration. Under his autograph, the Bureau became a purveyor of what I call editorial federalism, state supervision pursued through a cluster of text-centered desires and activities ranging from the archival to the authorial, the interpretive to the revisionary. Not just a kind of intragovernmental newspaper, a provider of crime bulletins and special investigative reports to Congress and the executive branch, Hoover's FBI grew to be a very real and very ambitious library, publisher, critic, and author-function, often aiming to catapult its words beyond the Beltway. Binding these various literary identities together was the central, 
unsecret mission of Hooverite editorial federalism: crossing the theoretically bright line between the compulsions of state power and the literate volunteerisms of civil society, inserting a beefed-up, well-read federal police presence into the print public sphere. The Bureau's sensitive cultural antenna quickly perceived alternatives to this sphere in a blossoming mass-media ecology-the FBI was only too happy to lend its technical advice and improbable star image to radio, the movies, and, later in the publicity game, television. All the same, Hoover's aggressive cultural programming never agreed to the demotion of the literary word, and never questioned the vitality of print within the citizens' theater of discursive exchange and political participation long involved in U.S. nation-building. Hoover's FBI entered this theater with words blazing, determined to rewire a public sphere originally intent on keeping police power at a critical distance. ${ }^{9}$

Passionate about "making personal replies to citizens who write to him praising the F.B.I.," the mature Hoover of the 1930 officially reserved his late-night hours for heroic authorship, scribbling away "past midnight" in his Justice Department office. ${ }^{10}$ Had his daytime schedule as FBI director allowed him to administer the physical printing of the Bureau's publications, he might have leaped at this literary task as well. The preteen Hoover ran off the Weekly Review at first hand, most likely on the government-issued letterpress of the Steamboat Inspection Service, where his brother Dick built his own small kingdom in the state bureaucracy (Powers, 20). Hoover's father, showing the way, had followed his own male parent into the print shop of the U.S. Coastal and Geodetic Survey (USCGS) and prepared for his managerial job by making plates for nautical charts. FBI scholars have relished speculating on the consequences of Hoover's upbringing in a patriarchal culture of cartography. Literary critic William Beverly is most inventive in claiming that the scientific national land survey that preoccupied the USCGS during the last decades of the nineteenth century provided a road map for the FBI's federalization of crime fighting. To Beverly's mind, the USCGS's transcontinental project ensured that "the unification and scientific refinement of regional representations into national maps [became] the family business" of Hoover men, a tradition of "suturing ... the nation's space" passed down through three generations. ${ }^{11}$ When a male Hoover graduated from removing local cartographic tics to eradicating interstate crime, his "effort to federalize police communication and surveillance" naturally "applied the nationalizing and mapping principles of his fore- 
fathers' work with the USCGS laterally to another medium." ${ }^{12}$ The notion of a lateral pass from uniform USCGS national maps to uniform FBI national crime reports is not implausible; in the parallel case of Soviet intelligence, the NKVD (predecessor of the KGB) thought it prudent to ingest the entire national map business. ${ }^{13}$ Yet the largest inheritance the USCGS left the Bureau was probably less abstract. Corroborating Franklin's self-publishing example, Hoover's print-shop legacy encouraged him to oversee Bureau representations at plate level, meddling everywhere from conception to consumption. Good press, the family business advised, belonged to those who operated one.

Guidelines for managing the publications of FBI foes, meanwhile, emerged from another federal paper mill, the Library of Congress, where Hoover first saw Franklin's documents and worked for tuition money while studying law at George Washington University. In 1913, Hoover was hired as a junior messenger, filling the Library's lowliest position to the tune of $\$ 30$ a month. When he left the Library in 1917, he was taking home twice this salary and tipped as a curatorial star in the making (Powers, 39-40). "I'm sure he would be the chief librarian if he'd stayed with us," a coworker later remarked. ${ }^{14}$ Over the four years in which Hoover discovered his talent for bibliography, the Library was pushed past the million-volume mark and into the front rank of American research collections by director Herbert Putnam, an "early example of the bureaucratic empire builder" eventually embodied by Hoover himself (Powers, 39). Putnam's first imperious scheme took aim at the Library's antiquated cataloging method, a "meager, rigid, and inelastic" tool, he protested, helpless to rescue the tons of unsifted paper rotting in the basement. ${ }^{15}$ Rejecting the Dewey Decimal system as arbitrary in its division and numeration of subjects, Putnam spearheaded the development of the entirely new Library of Congress classification, envisioned as a national standard from its auspicious origin in 1900.

In Clint Eastwood's murky Hollywood biopic J. Edgar (2011), the young Hoover seems to invent the Library of Congress cataloging system on his own from scratch and grit, the better to win the (typing) hand of his lifelong secretary/coconspirator, Helen Gandy. As it happened, however, Hoover's advancement at the Library required him to master Putnam's earlier creation, which replaced irregular, handwritten catalogs with mechanically reproducible printed cards, their finely differentiated subject headings set on anatomizing the whole of human knowledge. Posted afterward to the FBI, Hoover took Putnam's cards with 
him. Reorganizing scattered Bureau records once dominated by a masssurveillance listing of all known prostitutes, he installed an elaborate "Editorial File System" of his own. With this import from the Library of Congress, Hoover appears to turn the Michel Foucault of Discipline and Punish (1975) on his head. Foucault's discipline-dealing nineteenthcentury sociologists borrow the epistemic machinery of the card index from the Parisian criminal records division, quietly benefiting from the discoveries of sweeping penal surveillance. ${ }^{16}$ Reversing the pattern, the FBI chief seizes the card index back from the human sciences, rebalancing interdisciplinary accounts to the advantage of the police. In more homely terms of comparison, however, Hoover's file system kept Herbert Putnam rightside-up, embracing Library of Congress-style multidirectional cataloging in a "scientific format," each new item receiving a unique code, a generic classification, and all pertinent cross references. ${ }^{17}$ According to Hoover's arrangement, crimes, actual and potential, were logged and interlogged like the Library's books, and more than a few books like crimes. Possibly unlawful articles of language and literature ate up index cards as the FBI assumed the Library of Congress's national ambition, striving to become the criminological equivalent of Putnam's "bureau of information for the entire country." ${ }^{18}$ The novel plots and felonies invited by the instantaneous telegraph, the rapid surface transport stoking the "migratory nature" of modern radicals-both necessitated a central police directory, Hoover reasoned, a national register able to "ascertain in a few minutes the numerous ramifications" of suspicious persons, places, and texts. ${ }^{19}$

Hoover's opportunity to revise the Library of Congress classification was provided by an unbookish summons: a suicide bomb that demolished the front porch of Attorney General A. Mitchell Palmer's Washington home one night in June 1919, hard on the heels of a May Day bombing campaign aimed less accurately at dozens of senators, cabinet secretaries, Supreme Court justices, and the commissioner of immigration at Ellis Island. "The outrages of last night," a shaken Palmer lectured reporters on the morning after, "indicate nothing but the lawless attempt of an anarchistic element in the population to terrorize the country and stay the hand of the government." "Free speech has been outraged long enough," roared a more vengeful Washington Post. "Let there be a few free treatments in the electric chair." ${ }^{20}$ The Red Summer best known to students of African American literature, a season of labor strikes, twenty-five or more white riots, and unprecedented instruction in black self-defense, 
was thus initiated by a wave of radical terrorism and untamed conservative recoil. In its own time, this wave was credited to the revolutionary contagion of the biennio rosso, the "Red Years" baptized by the Italian Left and inaugurated by the 1917 Bolshevik takeover in Russia (Powers, 56). Since the devastation at the Pentagon and World Trade Center in 2001, the wave has been rediscovered as the "first $9 / 11$," a suddenly legible precedent raising questions on the balance of patriotism and pluralism, civil liberty and public security. ${ }^{21}$

Like the second 9/11, the first presented a shaken federal government, wounded in its city of refuge, with the chance to secure a secretpoliceman's wish list. No later than the end of June, Palmer's snap prediction that the bombings "will only increase and extend the activities of our crime detecting force" had been fulfilled. ${ }^{22}$ Congress supplemented the Justice Department's $\$ 1.5$ million antiradical drive by $\$ 500,000-$ about an extra $\$ 3,780$,000 and change in 2010 dollars. ${ }^{23}$ The increase went to fund a new unit within the Bureau of Investigation, the Radical Division, open for business on the first of August. Within a year, this forerunner of the Martin Luther King Jr.-harassing Domestic Intelligence section was the largest department in the FBI, boosting the number of Bureau agents from 301 to 579, occupying more than half of all headquarters' staff time, and confidently renaming itself the General Intelligence Division. ${ }^{24}$

The overt task of the Radical Division was to serve as a judicious, Department-of-Homeland-Security-style aggregator of terrorist threats to domestic tranquility, Palmer's eyes, ears, and editor in seeking "a thorough-going understanding of the situation as a whole." ${ }^{25}$ Equally weighty was the unwritten charge to consolidate the Bureau's advantage over the Secret Service and other intragovernmental police rivals while completing the federalization of political intelligence, the transfer of countersubversive power-knowledge away from autonomous urban "bomb squads" and Pinkerton-style private labor spies. This nationalizing of antiradical data-collection was given an enduring rationale by the antistatist Marxist internationalism of the Russian Revolution, and a trained constituency by World War I, the inspiration for blanket federal investigations of leftists under cover of the Espionage (1917), Sedition (1918), and Alien Acts (1918). According to Frank J. Donner, the dean of civil libertarian intelligence historians, the same Great War that bred "awareness of the potential effectiveness of intelligence as a weapon against domestic enemies" also mustered a bonus army of intelligence operatives, a large class of "soldiers, ex-officers, reservists, [and] patri- 
otic amateur detectives" schooled in espionage and "thirsting for peacetime assignments" once the firing stopped (47). The patriotic but draftdeferred Hoover did not have to wait long after the Armistice to reapply the craft of intelligence he had studied at the Enemy Alien Registration unit, a wartime annex of the Justice Department. In 1919, two years out of law school and the Library of Congress, he was tapped as the first head of Palmer's fledgling Radical Division and ordered to ensure there would be no repeat of the first $9 / 11$.

"Modern life requires the nimble brain of youth for work like that of [the Bureau]," theorized the Louisville Courier-Journal, favorably spinning Hoover's tender age. "Courage, daring, intuition, what is known as the 'sixth sense,' boldness tempered always by prudence," the paper affirmed, "are the requirements for success in intelligence work." ${ }^{26}$ In reality, off the feature page, the twenty-four-year-old Bureau administrator applied more boldness than prudence to the role of the New Spy, an unfriendly relative of the New Woman and the New Negro, one in a long string of smartly youthful modernist social types. Hoover's preventative war against "red terror" found him micromanaging an unparalleled roundup of radicals, judged by scope alone one of the most audacious police actions in American history. In November 1919 and again in January 1920, agents of the Bureau burst simultaneously into meeting halls, bowling alleys, theaters, and cafés, seizing upward of 10,000 mostly noncitizen anarchists, Communists, and Communist Labor supporters in over thirty U.S. cities. ${ }^{27}$ Membership in the affected radical parties was flexibly determined. Bureau agents arrested everyone at a session of a “Tolstoi Club," for example, enforcing their superiors' tendency to confound literary and political affiliations. ${ }^{28}$ Hundreds of casualties of the "dragnet inquiry" were then deported in line with extralegal procedures Hoover had rehearsed at the Enemy Alien unit: temptingly, the banishment of noncitizen revolutionaries did not qualify as a criminal proceeding under a 1918 congressional statute enshrining guilt by association. While the Harlem socialists at the Messenger magazine rationalized "that you cannot deport true ideas and principles by deporting persons" ("Deportation"), Hoover's Bureau had grounds to brag that the raids unsurgically removed the "brains of the ultra-radical movement." ${ }^{29}$

Years later, after the warrantless snatch-and-exile maneuver passed unfavorably into history as "the deportations delirium," then as the first "Red Scare," a model eruption of the paranoid style in American politics, 
Hoover adopted a firm policy of declining all responsibility. Don Whitehead's The FBI Story (1956), the closest thing to an authorized institutional biography, paints the roundup as a dark pre-Hooverite episode, a relatively irresponsible witch-hunt in which "the Bureau's agents were not trained to protect civil liberties." 30 The anticommunism of Hoover's Cold War FBI inherited none of the excesses of "Palmer's 'Red Raids," Whitehead attests, coining a formula for Palmer's responsibility more reductively possessive than even the more common "Palmer Raids." ${ }^{11}$ In truth, however, the facts and style of the matter suggest that history should recall the "Hoover Raids," sweeps designed amid the regimented fervor of the newborn Radical Division, as the crux of the Bureau's makeover as a national countersubversive command center. No pure product of mass hysteria, the Hoover Raids mark the rise of American anticommunism as a political initiative preceding the emergence of the Soviet Union as a genuine threat to U.S. security-all this while the $\mathrm{Bu}$ reau privately suspected that the 1919 bombings were the work of small anarchist cells. ${ }^{32}$

The single major decision on the raids Hoover did not makeconfining the ambush to easily expelled noncitizens-was one he could be counted on to perfect, having received the Radical Division post primarily because of his qualifications as an "alien expert" (Powers, 66). As for the rest of the planning, Hoover took operational control of "the attack on radicalism during the summer and fall of 1919" (66). With the media-coached wits of the New Spy, he isolated particular Communist factions and anarchist celebrities (never sharply distinguished) to lend a face to the enemy. Emma Goldman, the feminist-anarchist and free-loving "Queen of the Reds," became the raids' totemic target after Hoover's shocked review of "Patriotism: A Menace to Liberty" (1908) and like-minded Goldman contributions to Mother Earth. He personally presented the government's case at Goldman's deportation hearing, writing a long brief against the Communist Party that became a touchstone of the anticommunist imagination when reprinted during the Cold War. ${ }^{33}$ Conceivably relying on his father's contacts, he obtained detailed maps of northern Russia to assist the navigation of the U.S.S. Buford, the "Soviet Ark" that delivered Goldman and 248 other deported radicals to the infant Soviet Union (Powers, 88). Most crucial for the Bureau's management of editorial federalism, he prepared for all of the above by building the FBI into one of the world's great libraries of radical writ- 
ing, a collection larger than any American peer, whether private, public, or, like the Bureau's, taxpayer-funded, shamelessly peddled, and aggressively off-limits.

Hoover was unembarrassed to advance the impression that the Radical Division chief should more closely resemble Herbert Putnam of the Library of Congress than Sir Edward Henry of Scotland Yard, the dashing modernizer of the London Metropolitan Police who survived an assassin's bullet in 1912, then testified on his assailant's behalf. Like Henry's detectives, Hoover's were brain-working investigators, unlicensed to make arrests or carry guns until the gangster clashes of the 1930s. (In FBI apocrypha, the Bureau's call to arms is commemorated in Machine Gun Kelly's panicky coinage of an undying nickname: "Don't shoot, G-Men!") Yet unlike the tenants of Scotland Yard, Hoover's Gfor-government men were fact-finders who inspected more treatises than crime scenes (G-women were, then and later in the Hoover era, exceedingly few outside the typing pool). Those responsible for "bomb outrages," Hoover explained through an Annual Report of the Attorney General, split their time between assembling explosives and arranging insurrectionary phrases. ${ }^{34}$ Perhaps thinking of the pamphlets found at the sites of all the 1919 bombings, he claimed that the ultraradicals' "sole purposes were to commit acts of terrorism and to advocate, by word of mouth and by the circulation of literature, the overthrow of the Government of the United States by force and violence." 35 To Hoover, eager for deportation-worthy verbal evidence of revolutionary intent, propaganda of the deed and word were barely distinguishable, and literary knowledge was a heavy weapon of both terrorism and its governing foe. Gone was the Victorian insistence that labor agitators understood one rhetoric alone, physical force. In its place, Hoover's modern theory of bilingual extremism may have beaten the post-Marxist New Left to the conclusion that literary language in and of itself performed political action. ${ }^{36}$ In any event, Hoover's theory practically demanded that the Bureau swiftly obtain the "nucleus for an excellent working library."

Even in the storm of the Hoover Raids, this working library was nourished by a systematic extraction of leftist texts. "All literature, books, papers and anything hanging on the walls should be gathered up," the Bureau instructed agents prior to the busts (quoted in Schmidt, 285). Following the 1919 invasion of the Russian People's House in Manhattan, "several trucks" were requisitioned to remove dangerous treasure: not crates of firearms, but reams of writing (Powers, 78). Entire institutional 
libraries were swallowed by Hoover's, twenty-five tons worth in New York in January 1920 alone, commandeered "almost say by the bale," in the boast of Attorney General Palmer. ${ }^{38}$ Private collections were pinpointed for forced acquisition, with detectives prepared to infiltrate common hiding places for rare books: walls, ceilings, carpets, and mattresses, in addition to desks and safes. ${ }^{39}$ One down-and-out Italian philosopher returned home to find his one-of-a-kind set of anarchist theory packed as an involuntary donation (88). Sonia Kaross, a Lithuanian immigrant to Philadelphia detained in the second dragnet, marveled at the attention paid to "all my books, all my letters ... every little paper they could get hold of. They threw it all into big bags like the post office has . . . and I could never get anything back." 40 Thanks to Hoover's librarian-pirates, the Radical Division's "collection of pamphlets and books" soon contained the "constitutions, programs, and platforms of practically all of the extreme radical groups." ${ }^{\text {"1 }}$ Every pound of the collection was "savage material," declared Palmer, "but much of it infernally well written and appealing to the thoughtless, dissatisfied crowd." ${ }^{2}$ As conducted by the Bureau, the Hoover Raids were in no small part crusades to capture the left's devilishly attractive written relics.

No surprise, then, that Hoover's cataloging of the spoils called upon the imperial scope of the Library of Congress classification, calculated to allow specification within great volume, and acutely attentive to literary distinctions. The largest and longest-to-construct grouping in the Library classification was the Language and Literature category, what cataloging historians honor as the "monumental Class P." ${ }^{33}$ In Hoover's revision, the subjects of this grouping enjoyed comparably close attention. Already in December 1921, the cabinets of the Radical Division were crammed with "approximately 450,000" index cards addressing ominous "activities and subjects," many literary-criminal. ${ }^{44}$ For civil libertarians such as Louis Post, assistant secretary of labor, the Radical Division's "card-index system" was the heart of a "kaiseristic police mechanism," an appliance of the same Old World despotism the United States had only just defeated at the Marne and Belleau Wood..$^{45}$ For its fast-talking creator, however, this system was a welcome engine of publication as well as a signature apparatus of modern radical hunting.

Besides identifying candidates for deportation via "paper membership in a revolutionary group" (Donner, 39), Hoover's index served as a writerly black box in which text collection modulated into text creation, and the stimulus of Putnam's Library of Congress merged with that of 
the USCGS print shop. An exceptional state archive arose as a result, flaunted as a national treasure like its French and British relations but accessible to the public only through self-issued catalogues raisonnés. Rifling through the index for fresh affronts, the Radical Division furnished sympathetic newspapers with precomposed printing plates designed to warn "homes, religion and property" of the latest "menace of Bolshevism" (Donner, 39). Hoover edited a government-only paper of his own, the biweekly Bulletin of Radical Activities, its miscellaneous safety tips and atrocity exhibits recalling the recipe of his boyhood Weekly Review (Powers, 108). A pamphlet dubbed The Red Radical Movement (1920), circulated more generously to "all the magazines and newspapers in the United States," assembled photostats of the most militant publications grabbed during the Hoover Raids, a procession of radical spoils uncertain of historical victory. "Striking passages" had been "marked for convenience," instructed the pamphlet, inviting blood-curdling headlines and editorials (Schmidt, 295). Attorney General Palmer, after the June 1919 bombing a reader experienced with nighttime terror, blurbed the finished product as "interesting, significant, and entertaining" but unsafe for "late at night, when you are at home in your own house. It gives you the creeps a little." ${ }^{\prime 7}$ More literal-minded than the CIA, whose headquarters once disguised itself behind a plaque reading "Government Printing Office," the Bureau's Radical Division made itself a genuine government publisher, its central card index, the building block of editorial federalism, inspiring gothic tales ${ }^{48}$ Hoover's first formal publications, the index ensured, were essays in anticommunist bibliography laced with spythriller chills.

2. Hoover and the New Negro Renaissance:

\section{Radicalism and Sedition at Home}

Yet every other fruit of the Bureau's library paled next to a publication focused where editorial federalism bred with confrontational New Negroism. Before The Red Radical Movement raised its eerie head, Hoover lent his archive's authorial services to Radicalism and Sedition Among the Negroes as Reflected in Their Publications, a twenty-six-page narrative written and released in late 1919. The FBI's maiden voyage into advanced book-chat, Radicalism and Sedition rates as the American state's earliest acknowledgment of the New Negro Renaissance and as a seminal 
document of African Americanist criticism produced from any quarter. All bitter ironies admitted at the outset, this Hooverite production, promptly denounced by the Messenger as "vicious, reactionary, and race prejudiced," introduced nearly as much shaping pressure into the Afromodernist literary field as Langston Hughes's "The Negro Artist and the Racial Mountain" (1926), Zora Neale Hurston's "Characteristics of Negro Expression Expression" (1934), or Richard Wright's "Blueprint for Negro Writing" (1937), manifestos it prepared the Bureau to read as a matter of national gravity. ${ }^{49}$

Radicalism and Sedition, sometimes wrongly attributed to Hoover alone, was most likely researched, outlined, and slanted by several hands within the federal espionage community, among them lead ghost Robert Adger Bowen of the FBI's Bureau of Translations and possibly Major Arthur Loving of Army intelligence, the most valuable African American secret agent of World War I. ${ }^{50}$ Whatever its standing as an interracial, interdepartmental collaboration, however, the text's primary inspiration lay in Hoover's anxious scrutiny of the black share of the Red Summer. The finished text's schedule of deployment, moreover, was tightly bound with Hoover's ever-more-public role as a tract- and mindreading congressional informant, an expert purveyor, as David Levering Lewis terms it, "of confidences about the actions, ideas, and morals of American citizens." ${ }^{51}$ Starting life as a special report to the Attorney General, Radicalism and Sedition was exposed to Congress in 1919 in the Senate-mandated publication Investigation Activities of the Department of Justice, then extracted on the front page of the New York Times and distributed in pamphlet form by Hoover in 1920. Its opening sentence speaks ill of two repeat offenders: the first, the summer 1919 "race riots in Washington, Knoxville, Chicago, Omaha, and Arkansas"; and the second, the "more radical Negro publications ... quick to avail themselves of the situation as cause for the utterance of inflammatory statementutterances which in some cases have reached the limit of open defiance and a counsel of retaliation." ${ }^{2}$

With their fighting words, the New Negro voices amplified by Radicalism and Sedition opened a fresh domestic front in the war of verbal terrorism Hoover elsewhere fought against enemy aliens-a front identified, in this case, with widespread civil disorder rather than targeted assassination. Hoover personally witnessed the first race riot on Radicalism's list in the weeks before his posting to the Radical Division. Passing the worst of the Washington bloodshed on his way down Pennsylvania 
Avenue, the White House sidewalk a battle royale, Hoover's eyes were stung by "the Negro's pride in fighting back" (Radicalism and Sedition, 181). Radicalism and Sedition aptly quotes, at astonished length, an insider's report that Washington blacks "openly declare the war here ... the greatest event since the Civil War. The Negro has demonstrated right in sight of the White House and Congress which refuse to protect him or reward his loyalty that he is afraid neither to kill nor to die for so sacred a thing as liberty and home" (181). Facing "bands of armed mobs," the insider continues, D.C. blacks had organized themselves into gaily disciplined ensembles "shouting jubilant war songs, as if it were a carnival and gala day" (181). Those veiled in the belated segregation of the capital had noisily returned to light.

With New Negro militancy blurring the lines drawn during Hoover's adolescence-lines in Washington social geography, and perhaps in his own ancestry-Radicalism and Sedition retaliates with flights of fantastically definitive intelligence. "There can no longer be any question," it pronounces, "of a well-concerted movement among a certain class of $\mathrm{Ne}$ gro leaders of thought and action to constitute themselves a determined and persistent source of a radical opposition to the Government" (162). Trumpeting signs that the "ill-governed reaction toward race rioting" of these leaders invited both an "outspoken advocacy of the Bolsheviki" and an "openly expressed demand for social"-read sexual-"equality," the publication solders together an epochal conceptual chain (162). Radicalism and Sedition documents the birth-moment when Hoover's firstwave anticommunism fused with his defensive racism, and the Radical Division's speech-sensitive countersubversion program was bound to an imaginative New Negrophobia. The rest, as they say, is history-in this case, the history of an editorial federalism that climaxed in plans to arrest African American literature, via "Custodial Detention," at midcentury.

Attentive to several strains of black American writing, Radicalism and Sedition's survey of New Negro poetry, the groundwork genre of the Harlem Renaissance, is especially charged and scrupulous. Hoover and comrades cast this verse as the distillation of black-Red connection-the lyrical cement of the conceptual chain just mentioned-and reproduce nine poems encountered in an exhaustive survey of black periodicals. Surprised to learn that several of "the Negro magazines are expensive in manufacture, being on coated paper throughout, well-printed, and giving evidence of the possession of ample funds" (Radicalism and Sedition, 
162) Radical Division print-culture historians had launched a special project to monitor the "Negro Press" - the only ethnic English-language press so tracked by the FBI's Publication Section, later designated the Book Review Section (the cultural pages within the Bureau pictured as a true-crime magazine). ${ }^{53}$ The Bureau's spy-readers sweated over every issue of the groundbreaking Harlem Renaissance journals, the most intellectually significant black-run institutions of the Harlem Renaissance, classed by the bibliocentric Hoover among the "principal phases of the Negro movement into which inquiry should be made" (quoted in Kornweibel, 23). A. Philip Randolph's Messenger-a journal "well known to me," wrote Hoover ${ }^{54}$-struck the FBI director as a veritable "headquarters of revolutionary thought" (Kornweibel, 23). Marcus Garvey's multilingual Negro World impressed him as a disloyal advocate of "Soviet Russian Rule," despite the pages of anticommunist testimony to the contrary (quoted in Kornweibel, 23). The Harlem Crusader, Cyril Briggs's organ of the authentically Soviet-supporting African Blood Brotherhood, received the Bureau rating of "entirely radical" and unwittingly employed an undercover FBI mole, Earl E. Titus, as an advertising agent (Kornweibel, 230). All three of these journals, and fourteen more, play credited roles in Radicalism and Sedition, ransacked to demonstrate that "the Negro is 'seeing red"' and quoted "as fully therefrom" as space allowed (Radicalism and Sedition, 163). Catching word of all the spy-reading, W. E. B. Du Bois mordantly commented, "We black folk have for some years been trying to get the United States Department of Justice to look into several matters that touch us," lynching before magazine work..$^{55}$

What emerges from Radicalism and Sedition's tangle of citation is one of the better anthologies of early New Negro poetry, beating James Weldon Johnson's Book of American Negro Poetry to the punch by three full years, and Locke's 1925 New Negro edition of the Survey Graphic by half a modernist generation. The fourteen end-rhymed lines of Claude McKay's "If We Must Die" (1919) are reprinted with care, their communal extension of Measure for Measure's "If I must die" ${ }^{6}$ even then the designated driver of Harlem's renaissance.

If we must die, let it not be like hogs

Hunted and penned in an inglorious spot

While 'round us bark the mad and hungry dogs

Making their mock at our accursed lot. (lines 1-4) 
Couched as "a much-quoted poem about the negro [sic] with his back against the wall and fighting to the death," the sonnet's viral spread through the Negro world is charted in detail (Radicalism and Sedition, 163). Noncanonical hymns to martial self-sacrifice, McKay's silent partners in the shift from plantation dialect to a furiously elevated Standard English, are also presented in block. Carita Owens Collins's "This Must Not Be!" is transplanted intact from the Garveyite press.

And that same blood

So freely spent on Flanders fields

Shall yet redeem your race.

Be men, not cowards.

And demand your rights. (lines 11-15)

"Don't Tread on Me," a chorus from Harlem socialist-turned-jazz lyricist Andy Razaf, is relocated from the Crusader.

It's time for us "to do or die,"

To play a bolder part.

For by the blood you've spilled in France

You must and will be free.

So from now on let us advance

With this: Don't tread on me! (lines 11-16)

Brows are creased over "Her Thirteen Black Soldiers," a poem by American Negro Academy president Archibald Grimké commemorating actual Negro troops who absorbed McKay's teaching and retaliated against white assailants in Houston.

[America] had ears, but she stuffed them with cotton That she might not hear the murmured rage of her black soldiers.

They suffered alone, they were defenseless against insult and violence,

For she would not see them nor hear them nor protect them.

Then in desperation they smote the reptilian thing,

They smote it as they had smitten before her enemies,

For was it not her enemy, the reptilian thing, as well as their own?

(lines 9-15) 
Without quite meaning to, the collected verse of Radicalism and Sedition argues that the renaissance-firing paradigm change traced to McKay's "violent sonnets" in fact stems from a larger anomaly, the open-air laboratory of the New Negro's summer of retribution.

By contrast, Radicalism and Sedition's deliberate critical glosses offered little competition for Locke's or Weldon Johnson's. Most are thin, steeped in a stunted interpretive code in which literary interest is measured by ideological admissibility rather than by truth, beauty, or a less Romantic appetite for social action: "For certain of these publications there is not a good word to be said - all of their effort and product is bad, and intentionally bad" (Radicalism and Sedition, 87). Formal questions arise as pretexts for mockery, as in the aside noting "that a discriminating taste in verse structure and grammar was not one of the cultural effects of Harvard University upon the minds of the editors of the Messenger" (179). The uneasy comedy poking ivy-covered New Negroes nonetheless shades into Radicalism and Sedition's confessed respect for black writers "of education," their brash lyrics "not to be dismissed lightly as the ignorant vaporing of untrained minds" (162). The Negro World's pride in race authors equipped with "fine, pure English, with a background of scholarship behind them," was "not an idle one," Hoover and company finally concede (162). Reviewing Radicalism and Sedition for the New York Age, James Weldon Johnson shrewdly underscored that the honing of a "clear, intelligent, and forcible" New Negro voice "is what shocks the writer of the report more than anything else." 57 "He is a man who has evidently, like many others, been asleep on the Negro," Johnson deduces, and what "astonishes him most is the fact that these articles are written by Negroes who know how to use the English language" (n.p.). Robert Bowen's preliminary drafts of the report would have given Johnson deadlier ammunition, owning up to the "marked ability" of militant black authors and distinguishing their products from the "bombast and nonsense" of the "plantation negro preacher," an archetypal "Old Negro" authority. ${ }^{58}$ The New Negro "means business," Bowen confirmed, "and it would be well to take him at his word."59

The same Radical Division publication that made history by introducing Red Summer reaction to Red Years anticommunism thus also previewed FBI editorial federalism's long-haul posture toward Afromodernism. Here, as later in the age of Hoover, that posture was flexibly conflicted: versed in industrious, sometimes unrivaled research; 
deathly serious, if often inexact, about the seeming hotline between black aesthetic defiance and urban restiveness; leavened by ridicule of alleged technical deficiencies; yet shot through with nervous admiration for black erudition and sophistication of purpose, unwanted blows to the cultural crutches of racial hierarchy. How many refinements of "verse structure and grammar" finally separated McKay's barrack-room counsel from Hoover favorite Robert Service, the "Canadian Kipling" who hatched "The Shooting of Dan McGrew" (1907)? In the style of the Jamaican Kipling's “If We Must Die," Service's poems of racial regeneration through violence advised strivers to smile and scrap when facing unbeatable, evenly metrical walls.

If you're up against a bruiser and you're getting knocked aboutGrin.

If you're feeling pretty groggy, and you're licked beyond a doubt-

Grin. (“Grin," lines 1-4)

How comfortably distinct was Razaf's "Don't Tread on Me" from the pugnacious sing-song of "The Bully Bolsheviki," a poem scrapbooked and perhaps composed by Hoover himself, disrespectfully "dedicated to 'Comrade' Louie Post," the leading nemesis of the Hoover Raids?

The "Reds" at Ellis Island

Are as happy as can be.

For Comrade Post at Washington

Is setting them all free. (lines 1-4)

Confronting early New Negro verse, the margins of racial difference narrowed and blurred. Egged on by prickly likeness, enabled by a comprehensive indexed archive and its enticements to publication, the impulse to supervise African American writing became a constitutive inclination of Hoover's FBI, the enduring upshot of its linked investments in New Negro modernity and national literary influence. In the long run, the Bureau's observation of the darkening mirror of black literature was as vital to its cultural impact as the "War on Crime," the deadly and glamorous Depression-era battle with John Dillinger, Bonnie and Clyde, and other heartland mobsters/social bandits that ushered Hoover into the gossip columns and supposedly introduced the FBI to 
its classic self. When even shrewd Bureau historians defer to Hoover's promotion engine and plug the gangster era as the crucible in which a "band of amateurish agents" picked up the gun and became "the professional crime-fighting machine of yore," 60 they slight evidence that the "Hoover boys" wet their teeth by professionalizing literary surveillance for the American century. Studious G-Men (the $G$ is for ghostreading, too) transformed the Bureau into the head office of U.S. editorial federalism, part library, part authors guild, part literary-critical school, and part editorial board, all parts committed to sowing state authority in the print public sphere. For decades after winning the first of several crime wars, they aimed this federalism at public enemies armed with book contracts, dozens of them the creators of Afro-modernism.

Notes

1. In correspondence with an official of the FBI's Record/Information Dissemination Section, I learned that Margaret Walker's national headquarters dossier was in all probability "destroyed on November 12, 2003" under provisions of a joint FBI-National Archives Records Retention Plan, the ironic result of a 1980 case brought to prevent wholesale file-purging and preserve FBI documents of special historical value (David M. Hardy, Section Chief, Record/Information Dissemination Section, Federal Bureau of Investigation, letter to the author, 14 Nov. 2006). Another cache of FBI paperwork on Walker, once kept by the Bureau's Miami field office, was similarly "destroyed [in] September of 1990" (Hardy, letter to the author, 16 May 2007). Procedures for judging the historical importance of aging Bureau files thus show the need for a consulting African Americanist. Much more rarely, Bureau records policy would do well to err on the side of repression. My FOIA request for the file of William Attaway, author of Blood on the Forge (1941), for example, mistakenly outed the thirty-page file of "Wild Bill" Attaway, volunteer Bureau informant and "American Republican Revolutionist" (Federal Bureau of Investigation, William ["Wild Bill"] Attaway file obtained under provisions of the Freedom of Information Act: assorted documents dated 6 June 1945 to 5 July 1950, internal case file no. 14-34720).

2. J. Edgar Hoover, Directive to FBI field offices on Custodial Detention policy, 6 Dec. 1939. In U.S. Select Committee to Study Governmental Operations with Respect to Intelligence Activities, Hearings before the Select Committee to Study Governmental Operations with Respect to Intelligence Activities of the United States Senate: Vol. 6 (94th Cong., 1st sess.; Washington, DC: GPO, 1976), 409.

3. For more on what I elsewhere describe as "COINTELPRO minstrelsy", or the efforts of FBI counterintelligence officers to counterfeit and frustrate the literature of Black Power, see chapter 2 of my forthcoming book FB Eyes: How J. Edgar Hoover's Ghostreaders Framed African American Literature.

4. Accounts of the Bureau's "war on words" - a vivid phrase of journalist Natalie Robins that unintentionally snubs the Bureau's war of words-can be found in her 
indispensable book Alien Ink: The FBI's War on Freedom of Expression (New York: William Morrow, 1992), as well as in Herbert Mitgang's Dangerous Dossiers: Exposing the Secret War Against America's Greatest Authors (New York: Ballantine, 1989); Claire A. Culleton's Joyce and the G-Men: J. Edgar Hoover's Manipulation of Modernism (New York: Palgrave Macmillan, 2004); and the Claire A. Culleton and Karen Leick-edited anthology Modernism on File: Writers, Artists, and the FBI, 1920-1950 (New York: Palgrave, 2008), which explores the FBI's prying into Continental European film and art culture as well as Anglo-American literature. Erin G. Carlston includes an illuminating review of this last title, complete with reflections on the burgeoning academic genre of "the criticism of FBI files," in "Modernism under Surveillance: American Writers, State Espionage, and the Cultural Cold War" (American Literary History 22, no. 3 [2010]: 617). On the somewhat better-studied topic of the Bureau's "secret file on black America" - a phrase of intelligence historian Kenneth O'Reilly's-see his influential history "Racial Matters": The FBI's Secret File on Black America, 1960-1972 (New York: Free Press, 1989) and his documentary collection Black Americans: The FBI Files (New York: Carroll and Graf, 1994), assembled with editorial help from David Gallen. See also, among a growing array of sources on individual cases, volume two of Robert A. Hill's edition of The Marcus Garvey and Universal Negro Improvement Association Papers (Berkeley: University of California Press, 1983); Clayborne Carson's Malcolm X: The FBI Files (New York: Carroll and Graf, 1991), also edited by David Gallen; Michael Friedly's Martin Luther King, Jr.: The FBI File (New York: Carroll and Graf, 1993), yet another Gallen-assisted compilation; and David Garrow's scrupulously measured study The FBI and Martin Luther King, Jr.: From "Solo" to Memphis (New York: W. W. Norton, 1981). Synthesizing "war on words" and "secret file on black America" approaches to FBI history is a basic purpose of this chapter.

5. Addison Gayle Jr., Introduction to The Black Aesthetic, ed. Gayle (Garden City, NY: Anchor-Doubleday, 1972), xx.

6. John K. Young, Black Writers, White Publishers: Marketplace Politics in Twentieth-Century African American Literature (Jackson: University Press of Mississippi, 2006), 7.

7. Richard Gid Powers, Secrecy and Power: The Life of J. Edgar Hoover (New York: Free Press, 1987), 20. Subsequent references to this work will be made parenthetically.

8. William H. Epstein, "Counter-Intelligence: Cold-War Criticism and EighteenthCentury Studies," ELH 57, no. 1 (1990): 77.

9. On the comparatively humble function of intelligence services as intragovernmental newspapers-"global news service[s], delivering daily bulletins"-see Tim Weiner's discussion of President Harry Truman's plans for the CIA (Legacy of Ashes: The History of the CIA [New York: Doubleday, 2007]). On the coalition of printcapitalism, the public sphere, and national identity in the uniting of the United States, see Michael Warner's seminal The Letters of the Republic: Publication and the Public Sphere in Eighteenth-Century America (Cambridge: Harvard University Press, 1990), and its recent, disuniting challenges in Trish Loughran's The Republic in Print: Print Culture in the Age of U.S. Nation Building, 1770-1870 (New York: Columbia University Press, 2007) and Leonard Tennenhouse's The Importance of Feeling English: American Literature and the British Diaspora, 1750-1850 (Princeton: Princeton University Press, 2007). 
10. Alexander Jack, "The Director-I," New Yorker (25 Sept. 1937): 20.

11. William Beverly, On the Lam: Narratives of Flight in J. Edgar Hoover's America (Jackson: University Press of Mississippi, 2003), 33; emphasis in original.

12. Ibid.

13. Alexey V. Postnikov, "Maps for Ordinary Consumers versus Maps for the Military: Double Standards of Map Accuracy in Soviet Cartography, 1917-1991," Cartography and Geographic Information Science 29, no. 3 (July 2002): 248.

14. Quoted in Curt Gentry, J. Edgar Hoover: The Man and the Secrets (New York: W. W. Norton, 1991), 67.

15. Leo E. LaMontagne, American Library Classification: With Special Reference to the Library of Congress (Hamden, CT: Shoe String Press, 1961), 229.

16. Michel Foucault, Discipline and Punish: The Birth of the Prison, trans. Alan Sheridan (New York: Vintage, 1979), 281.

17. U.S. Dept. of Justice, Annual Report of the Attorney General of the United States for the Fiscal Year 1919 (Washington: GPO, 1920), 173.

18. Charles A. Goodrum and Helen W. Dalrymple, The Library of Congress (Boulder: Westview Press, 1982), 37.

19. U.S. House, Attorney General A. Mitchell Palmer on Charges Made Against Department of Justice by Louis F. Post and Others: Hearings Before the Committee on Rules. 66th Cong., 2nd sess., Part 1 (Washington: GPO, 1920), 166. Subsequent references to this source will be made parenthetically.

20. The quotations in this paragraph all appear in "'Attempt to Terrorize Has Failed, Says Palmer," Washington Post, 4 June 1919, 1.

21. Kenneth D. Ackerman, Young J. Edgar: Hoover, the Red Scare, and the Assault on Civil Liberties (New York: Carroll and Graf, 2007), 392.

22. Quoted in “'Attempt," 1.

23. Frank J. Donner, The Age of Surveillance: The Aims and Methods of America's Political Intelligence System (New York: Vintage, 1981), 33. Subsequent references will appear parenthetically.

24. Rhodri Jeffreys-Jones, The FBI: A History (New Haven: Yale University Press, 2007), 72.

25. U.S. Dept. of Justice, Annual Report of the Attorney General of the United States for the Fiscal Year 1919 (Washington: GPO, 1919), 13.

26. Quoted in J. Edgar Hoover, Scrapbooks. Records of the Federal Bureau of Investigation (RG 65), Director's Office Records and Memorabilia, J. Edgar Hoover's Scrapbooks, box 1, July 1921 to Dec. 1924 folder. U.S. National Archives and Records Administration, College Park, Maryland.

27. David Williams, "The Bureau of Investigation and Its Critics, 1919-1921: The Origins of Federal Political Surveillance," Journal of American History 68, no. 3 (Dec. 1981): 561.

28. Williams, 562 .

29. Regin Schmidt, Red Scare: FBI and the Origins of Anticommunism in the United States (Copenhagen: Museum Tusculanum Press, 2000), 275.

30. Don Whitehead, The FBI Story: A Report to the People (New York: Random House, 1956), 14.

31. Whitehead, 46. 
32. Schmidt, 19, 149, 362 .

33. The Cold War eminence of Hoover's 1920 case against the Bolsheviks is highlighted by J. Edgar Hoover Speaks Concerning Communism (1970), a quotable tool for "all anti-Communists" compiled by James D. Bales (Bales, front matter). "Hoover's prophetic and chilling brief on the Communist Party delivered in 1920" is hailed on the dust jacket and enshrined in a chapter of its own.

34. U.S. Dept. of Justice, Annual, 1920, 171.

35. Annual, 1920, 172.

36. Sean McCann and Michael Szalay, "Do You Believe in Magic? Literary Thinking after the New Left," Yale Journal of Criticism 18, no. 2 (2005): 440-41.

37. Annual, 1920, 178.

38. U.S. House, Attorney General, 18.

39. Max Lowenthal, The Federal Bureau of Investigation (New York: William Sloane, 1950), 88 .

40. Bud Schultz and Ruth Schultz, It Did Happen Here: Recollections of Political Repression in America (Berkeley: University of California Press, 1989), 162.

41. U.S. Dept. of Justice, Annual, 1921, 129.

42. U.S. House, Attorney General, 18.

43. LaMontagne, 246.

44. U.S. Dept. of Justice, Annual, 1921, 129.

45. Louis F. Post, The Deportations Delirium of Nineteen-Twenty (New York: Da Capo, 1970), 47.

46. U.S. House, Attorney General, 208.

47. U.S. House, Attorney General, 155.

48. Allen Dulles, The Craft of Intelligence (New York: Harper and Row, 1963), 6-7.

49. "A. Mitchell Palmer," The Messenger 2, no. 7 (August 1920): 75.

50. David Levering Lewis, W. E. B. Du Bois: The Fight for Equality and the American Century, 1919-1963 (New York: Henry Holt, 2000), 7.

51. Ibid.

52. U.S. Senate, Radicalism and Sedition Among the Negroes as Reflected in Their Publications. Exhibit 10, Investigation Activities of the Department of Justice, 66th Cong., 1st sess, doc. 153 (Washington: GPO, 1919), 161-62. Further references to this document will be made parenthetically.

53. Theodore Kornweibel Jr., "Seeing Red": Federal Campaigns Against Black Militancy, 1919-1925 (Bloomington: Indiana University Press, 1998), 71. Subsequent references to this source will be made parenthetically.

54. Quoted in Patrick S. Washburn, A Question of Sedition: The Federal Government's Investigation of the Black Press During World War II (New York: Oxford University Press, 1986), 23.

55. Quoted in Jeffreys-Jones, 6.

56. William Shakespeare, Measure for Measure [1623] (New York: Washington Square-Folger Shakespeare Library, 2005), 3.1.93.

57. James Weldon Johnson, "Report of the Department of Justice on Sedition Among Negroes," The New York Age, 12 Dec. 1919: n.p. 
58. Robert Adger Bowen, "Radicalism and Sedition Among the Negroes as Reflected in Their Publications," draft of 2 July 1919, ts. Robert Adger Bowen Papers, box 10, folder 86, Special Collections Unit, Clemson University Libraries, Clemson, South Carolina: 1.

59. Ibid.

6o. Bryan Burrough, Public Enemies: America's Greatest Crime Wave and the Birth of the FBI, 1933-34 (New York: Penguin, 2005), front matter. 


\author{
Gene Andrew Jarrett
}

\title{
LOOSENING THE STRAIGHTJACKET
}

\author{
Rethinking Racial Representation \\ in African American Anthologies
}

Right now, I am preparing a major anthology of African American literature spanning from the eighteenth century until the present. To be published by Wiley-Blackwell, the anthology requires the consideration of several intellectual and editorial issues, such as the historical value of certain literary works, their ongoing scholarly relevance, their commercial viability, their pedagogic utility, their copyright expenses, and the diversity of their authors, forms, and themes. While conducting research, I have surveyed the opinions of many teachers, students, and scholars who either specialize in African American literary studies or engage this academic field in passing. The ideas and suggestions they have offered are meaningful not only to the anthology itself, but also to the affirmationwhich, personally, I was also seeking - that the texts and contexts of African American literature remain exciting topics of inquiry.

The Wiley-Blackwell anthology's scope testifies, first of all, to the remarkable growth of African American literary studies since its academic expansion and institutionalization in the 1960s and 1970s. Periodized according to race, ethnicity, politics, history, culture, and methodology, the scope ranges from the literatures of Africa, Middle Passage, slavery, and freedom in the early national and antebellum periods; to the modern period of New Negro aesthetics, culture, and politics between the Civil War and World War II; to the contemporary period in which the canon, tradition, and criticism of African American literature have undergone reform. The scope also incorporates either the reassessment of American canons more broadly or the rediscovery and close reading of texts still absent from them. The scholarly field has come to appreciate the hemispheric expanse of American literature beyond the geographic 
boundaries and imaginaries of the United States proper; to outline the literature's transatlantic and transnational dimensions; to identify its documentation of contact between and among writers of putatively different races or ethnicities; and to limn its historical interface of cultural aesthetics with politics, informally and formally understood. ${ }^{1}$ Such forays of American literary studies, I believe, should find reflection in any comprehensive yet cutting-edge anthology of African American literature. For that reason, while the Wiley-Blackwell anthology reprints and discusses a particular literary canon or tradition, it is not restricted to the scholarly canon or tradition that has historically focused on it alone.

Compiling the anthology has been challenging so far. I have been grappling with its inherent contradiction: the tension between the political legacy of race in African American anthology-making-a core activity in canon formation-and the "postracial" vogue during which the anthology likely would be marketed, sold, and taught. Subtly, that tension emerges, for example, in the venerable anthology of African American literature, principally edited by Henry Louis Gates Jr. and Nellie Y. McKay, first released by W. W. Norton in 1997 and again as a second edition in 2004. In "Principles of Selection," the second part of the preface to the first edition, we learn that "The Norton Anthology of African American Literature is a celebration of two centuries of imaginative writing in English by persons of African descent in the United States." ${ }^{2}$ The second edition elaborates the anthology's goal as not solely a "celebration" but also a canonical strategy, implementing "our [or the general and section editors'] argument that the scholars of our literary tradition needed first to construct a canon before it could be deconstructed," or before that canon's limitations could be exposed.

Our task, then, was not primarily to bring lost or obscure texts back into print; rather, it was to make available in one representative anthology the major texts in the tradition and to construct a canon inductively, text by text, period by period, rather than deductively-that is, rather than through a priori ideological or thematic principles agreed upon in advance, which would function like a straightjacket for our selections. (My italics) ${ }^{3}$

The peculiarity of this mission lies in the relationship between, on the one hand, the editorial desire to avoid "agree[ing] upon in advance" certain "a priori ideological or thematic principles" and, on the other, the 
stated "argument that the scholars of our literary tradition needed first to construct a canon before it could be deconstructed." What makes something "ideological" (as opposed to philosophical) is the extent that, in order to exist, it does not necessarily require actual, verbalized consent among its purveyors. As political scientist Michael C. Dawson notes, ideology is "a worldview readily found in the population, including sets of ideas and values that cohere, that are used publicly to justify political stances, and that shape and are shaped by society." Canonical "ideas and values" could well be invisible to the eyes of anthologists but still prescribe their vision. The problem of preparing an anthology, I would argue, is not whether anthologists should or should not agree on and deduce canonical selection from a set of "ideological or thematic principles." Rather, the problem is how to render that ideology visible, to explain how and why a "worldview" responsible for these principles could become so "readily found in the population" in the first place. More to the point, as an anthology editor, I am more than willing to accept the default a priori status of ideology as a precondition for canonical methodology. I am more concerned about how such ideology could become the "straightjacket" of canon formation and, if we continue with the cynical metaphor, how we could loosen its grip.

For the balance of this essay, I will make the case that the methodology and organization of African American anthologies have been, and continue to be, crucial to understanding and critiquing what I regard as the double-laced straightjacket in question: a priori literary ideologies of race and racism. Loosening its grip requires rendering less familiar, less intuitive, the doctrine that the best African American anthologies are those that authentically portray the cultural expressions and political struggles of African Americans. I aim to cast new light on the "surprising" idea, for example, that "the trade edition [of The Norton Anthology of African American Literature] was purchased in great numbers by nonacademics, often members of the growing African American reading

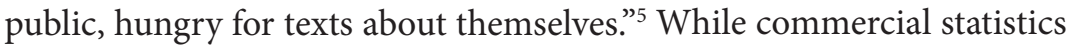
may support this statement-even its claim to an exacting racial demography of the anthology's readership-I am suspicious of the allegation, applicable to this collection and many others, that an anthology's appeal to African American readers results from the latter's aching desire for literary self-portraiture, and that fulfilling this desire could, in turn, become a basis for canon formation. As the new millennium progresses, such an allegation runs counter to the increasing diversity of the African 
Diaspora in the United States as well as to the increasing ambivalence, if not contestation, of the nation's readers over the dominance of race in categorizing this group. The election of Barack Obama, a man born from a black Kenyan father and a white Kansan mother, as the fortyfourth president of the United States has persuaded some that, despite the nation's checkered past of racial prejudice and discrimination, we are living in a world where race no longer matters-insofar as race no longer prohibits the political success of African Americans as much as it had in the past. How does one usher a canon into a new millennium, then, whose political circumstances, in some ways, undercut that canon's historical claim to racial politics? Here, I will suggest that editing an African American anthology in a postracial era entails counterbalancing the idea that its readers might be "hungry for texts about themselves" against the idea that they might also be awaiting their own disarticulation from the straightjacket of racial authenticity and representation in African American political history.

We cannot take this political history lightly. To imply, as many anthologies have, that "African American literature" signifies literature by, about, and for African Americans is not merely to utter a definition but also to determine many other things: such as the way authors think about and write the literature, the way publishers classify and distribute it, the way bookstores receive and sell it, the way libraries catalog and shelve it, the way readers locate and retrieve it, the way teachers, scholars, and anthologists use it, the way students learn from it-in short, the way we know it.

In controversial terms, Ward Connerly has alluded to this point. In "Where 'Separate but Equal' Still Rules," a New York Times Op-Ed article published on May 8, 2000, the chairman of the American Civil Rights Institute urges bookstores to resist classifying and judging the content of a book solely by the author's skin color. Consistent with his relentless agitation against racial preferences in U.S. higher education, the article bemoans the "racial profiling" of his books and of books published by those who share his likeness.

The shelving of their books in a special section [called "AfricanAmerican Interest"] deprives black authors or "race" authors of significant sales opportunities, putting them at a competitive disadvantage compared with authors whose books are not ghettoized. But the economic harm pales in contrast to the intellectual 
and cultural damage caused by the bookstores' version of racial profiling. They have fallen into the trap of thinking that a writer's skin color is a reliable guide to judging the contents of his or her books. My book, like those by other writers who happen to be black, is meant for readers of any race interested in the subjects and controversies I address. By relying on a blatant stereotypethat blacks are the only ones interested in the history, culture, and politics of black people-the bookstores marginalize some writers and limit their ability to reach out to a broader audience and to share common bonds and values. ${ }^{6}$

Let me stress here that quoting Connerly's words at length does not mean that I endorse his mission to enforce color-blind policies in higher education. Reciting them does begin to show, though, the extent that his frustration with what Katya Gibel Azoulay, a cultural theorist, has termed an "essentialist reification of race" has resonated in a mainstream venue (such as the New York Times) and should be taken seriously. Policy motives aside, his reference to a customary racial metonym in bookstores (the "African American Interest" shelf) reveals, to borrow Azoulay's words again, the "theoretical gap" between the bookstore's marketing of his work and his identification of his own work.?

The commercial and academic customs of U.S. bookstores and of African American literary anthologies, respectively, are not so different. In U.S. academic culture, the commerce and criticism of African American literature are overlapping enterprises. Both tend to elevate historical conventions of racial politics - that is, the prominent role that race has played in power relations, either in government or in informal society, among people across time-over the individual, and sometimes contrasting, interests of authors whom this history has cast as part of the long African American civil rights struggle. Put bluntly, the pride of African American anthologies lies in its literary compilation of racial politics, which have a lot to do with representations of racial authenticity.

Since slave narratives were published in the first half of the nineteenth century, literature written by African Americans-or, more precisely, by people who are identified or who identify themselves as African American-must be "the real thing," a window into the African American experience, in order to have any aesthetic, cultural, social, political, or commercial value. The additional promotion of certain images and tropes through the African American canon typifies a long-standing 
and quite anxious effort among the canon's authors and arbiters, dating back to their intellectual critiques of blackface minstrelsy, to control cultural and political portrayals of the race as much as possible, to shield them from stereotypes and other kinds of racist contamination. While understandable and, on countless occasions, necessary for redressing misconceptions of African Americans writ large, such an obsession with racial representation has perpetuated the wrongful belief that the best and most useful African American literature depicts the race. ${ }^{8}$

In the few decades after slavery, the earliest and most remarkable example of a writer who suffered from the culture of racial authenticity is Paul Laurence Dunbar, whose legacy is enjoying a scholarly renaissance today. A century ago, Dunbar died both separated from his wife and an alcoholic at the young age of thirty-three. By the time he died in 1906, he had published four novels, four collections of short stories, and fourteen books of poetry, as well as many songs, plays, and essays in newspapers and magazines around the world. He was the first professional writer born to emancipated slaves to become a phenomenon in this country. The centennial of his death has led to a recent blitz of publications. Beyond these issues, what makes Dunbar so remarkable today is that the circumstances of his emergence as the first "Negro Laureate" of the United States continue to teach us not to prejudge a book by the author's skin color.

In the early months of 1896 , James A. Herne, a preeminent actor and playwright, returned to his hotel in Toledo, Ohio, where his play Shore Acres was running, and learned that Dunbar had left him a gift with the hotel clerk. After attending and enjoying Shore Acres, Dunbar decided to leave Herne a complimentary copy of his second and latest book of poetry, Majors and Minors. Herne turned out to be well acquainted with the "Dean of American Letters," William Dean Howells, and Herne passed Majors and Minors on to Howells. Both men were captivated by the frontispiece of the book, an image of Dunbar at age eighteen. Howells found the image so compelling that he decided to review the book in Harper's Weekly. Howells called Dunbar "the first man of his color to study his race objectively" and "to represent it humorously, yet tenderly, and above all so faithfully." For the benefit of his readers, he also described Dunbar's facial features: "In this present case I felt a heightened pathos in the appeal from the fact that the face which confronted me when I opened the volume was the face of a young negro, with the race traits strangely accented: the black skin, the woolly hair, the thick outrolling lips and 
the mild, soft eyes of the pure African type."9 A black star was born, but perhaps for the wrong reasons. What Howells did, although in an antiquated and especially racist fashion, is similar to what readers do today: they presume what a book is about based on what the author looks like. ${ }^{10}$

During Dunbar's time and afterward, it turned out that some of our most celebrated African American authors had written noteworthy, even beautiful, literature resisting prevailing conventions of racial representation, despite the cost of critical dismissal and commercial failure. Certain authors have tried to counteract literary acts of racial profiling. The most famous case is Jean Toomer. Against the advice of publisher Horace Liveright that he mention his "colored blood" in the publicity for Cane (1923), Toomer reiterated his autonomy: "My racial composition and my position in the world are realities which I alone may determine." Toomer preferred to be called a national or American writer; he refused to allow race to determine too much his identity as a person and an artist. ${ }^{11} \mathrm{Un}$ fortunately, this kind of historical record-of authors' rebuffing the racial identities thrust upon them-has had little impact on the definition of African American literature. This definition has long imposed a mythical "one-drop rule" on authors, meaning that one drop of African ancestral blood coursing through their bodies makes them black. It has also dictated African American canon formation and misled readers into believing that African Americans write best only about African Americans. And readers continue to have this belief not because they think about it as deeply as they should, but because they focus on the author's likeness. Although readers know by heart "not to judge a book by its cover," they are still likely to remain superficial and prejudge the content of a book based on the author's skin color. And if that book defies their expectations or presumptions, they ignore or devalue it.

Over the past century, anthologies of African American literature have indoctrinated generations of readers into taking for granted this sort of theoretical, or taxonomic, gap between how writers identify themselves and their works and how their readers are inclined to. That gap has led to a host of problems, even when anthologists have appreciated and, in some cases, tried to recover the authors for posterity. According to one relatively recent academic forum, the anthologies indicate "the collective project, ongoing since the late sixties, of expanding the canon and curriculum of American literature, especially in response to the activism and scholarship of feminists and people of color." While aiming to teach students about the ethnic diversity of American culture, the collections also presume an authentic version of ethnic literature in 
which the representation of ethnic characters must correspond to the actual ethnic identity of their authors. ${ }^{12}$ The reason for this tendency has a lot to do with politics.

The political value of canon formation obtains even in something as innocuous as the activity of preparing an anthology. Selecting entries, even as this process accounts for the unavoidable restrictions of textual word count and, if they exist in the private domain, copyright costs, could privilege certain forms, themes, and methodologies in the scholarly fields to which the anthologists belong. In African American canon formation, there has been an ideological consistency, across history, in the exclusion of unconventional or anomalous texts from African American literary anthologies, a consistency resulting from what theorist John Guillory has called a relationship between "a politics of representation in the canon" and "a democratic representational politics" in the U.S. academy. ${ }^{13}$ A consequence of ethnic canon formation, however progressive it may be in introducing underrepresented ethnic minorities into American literature, has been the denigration or neglect of a class of writers whose literary works defy the protocols of ethnic authenticity and representationnamely, the casting of ethnic protagonists and the use of their historically associated typologies of vernacular, historical themes, cultural geographies, political discourses, or subjectivities. "African American literature" is no exception: the canonical conditions responsible for the marginality of certain texts come from the presumption that exhibiting African American experiences in authentic and representative ways is necessary-the analogous kind of presumption, ironically, that had justified moving African American literature in the late 1960s from the margins to the center of the larger American canon, precisely because portrayals of African American experiences had been missing from it.

The marginalization of certain literary texts has been a recurring structural consequence of canon formation to the extent that we could even accept it as an unavoidable problem. Yet I would counter that if our preoccupation with authentic political representations of race and racism happens to inspire that marginalization, then we should consider alternative methodologies and organizations of canonical anthologies. At the very least, doing so would mitigate the inherent gravitation of these representations toward reducing the sophistication of literary narratives of human experience. Literary reductionism of this sort should not be inevitable, despite the ostracizing tendencies of canon formation, as long as editorial principles are properly developed to counteract it.

I should state here that my critique does not necessarily intend to 
erase the categories of African American literature and, generally, ethnic literature, simply because such reductionist canons exist. Just as certain universities once warranted-and, in some cases, still warrant-the institution of African American studies as a self-contained department or as one program among many underrepresented ethnic Others under the rubric of American studies, African American literature likewise warrants anthologization as an individual entity. ${ }^{14}$ Yet, although anthologies work to protect underrepresented ethnic literature from marginality in canons founded on, say, the racism of white supremacy, we still must try to overcome the racial essentialism that may afflict our reading of canons. Put another way, just as we must overcome the erroneous myth that certain races must have certain essential characteristics, we must overcome the one saying that appreciable African American literature must have essential characteristics. I submit that editorial ventures should neither restrict anthologies to these myths, which are often grounded in race, nor forget the ways that certain African American writings, even if not anthologized, could still be noteworthy for trying to move beyond race.

In 2006, I edited a collection, African American Literature beyond Race: An Alternative Reader, that sought to demonstrate this canonical philosophy. The book features a number of authors who, though canonical in their own right, wrote literature whose casting of racially white, unmarked, or ambiguous characters in leading roles tended to be a historical aberration. (A number of preeminent scholars, including George Hutchinson, one of the editors of this book, wrote headnotes to introduce and examine these anomalous texts.) Seeking to overcome the critical and commercial demands for racial representation, the published short stories, novelettes, or full novels include Francis Ellen Watkins Harper's Sowing and Reaping (1876-77); Paul Laurence Dunbar's The Uncalled (1898); Nella Larsen's "The Wrong Man" and "Freedom" (1926); Jean Toomer's York Beach (1929); Wallace Thurman's The Interne (1932); Ann Petry's Country Place (1947); Zora Neale Hurston's Seraph on the Suwanee (1948); Chester Himes's Cast the First Stone (1952); Richard Wright's Savage Holiday (1954); James Baldwin's Giovanni's Room (1956); Samuel R. Delany's “Time Considered as a Helix of Semi-Precious Stones" (1968); Toni Morrison's "Recitatif" (1983); and Octavia Butler's "Bloodchild" (1984). The challenges these unconventional works of fiction have faced include going unread, undersold, or out of print in the commercial marketplace, while being stigmatized by scholars as anomalous within the authors' oeuvres or in African American literary history. 
African American Literature beyond Race has aimed to recover these books, arguing that African American avoidances of racial representation were not literary failings but innovative ways of investigating our common humanity, in spite and because of racial differences. ${ }^{15}$

I would be remiss if I do not reiterate here in 2012, as I did in 2006, that describing any move beyond human difference, such as race, must proceed with caution. The concept of "postrace" has emerged, most notably, in reference to well-educated, exciting, elected, and mostly Democratic African American officials, whose dates of birth reveal that they were only children during the modern Civil Rights movement, and whose credentials at Ivy League institutions highlight their common ability to navigate majority-white societies while excelling in rigorous academic environments. ${ }^{16}$ In part, this profile explains why the "appeal" of Cory Booker, mayor of Newark, New Jersey, and President Barack Obama "transcends race," according to magazine writer Peter J. Boyer: "Both men, reared in the post-Selma era and schooled at elite institutions, developed a political style of conciliation, rather than confrontation, which complemented their natural gifts and, as it happens, nicely served their ambitions." ${ }^{17}$ In the popular imagination, a postracial moment promises a present and a future in which race is no longer the main determinant of social relations and of the nation's democratic growth.

A more deliberate, scholarly approach, however, would suggest that the idealism of a postracial era should not distract us from the cultural and political realities of race today. We should balance the two, if such a postracial world is worth striving for, and guidance for doing so does not necessarily have to come from our contemporary moment. Words from "The Value of Race Literature," the lecture Victoria Earle Matthews delivered on July 30, 1895, at the First Congress of Colored Women of the United States, have proven prophetic enough. In the final paragraph, Matthews describes the generational importance of anthologizing "Race Literature," or what we now call African American literature.

The lesson to be drawn from this cursory glance at what I may call the past, present and future of our Race Literature apart from its value as first beginnings, not only to us as a people but literature in general, is that unless earnest and systematic effort be made to procure and preserve for transmission to our successors, the records, books and various publications already produced by us, not only will the sturdy pioneers who paved the way and laid the 
foundation for our Race Literature be robbed of their just due, but an irretrievable wrong will be inflicted upon the generations that shall come after us.

In the century after this address, anthologies of African American literature have met Matthews's challenge, reprinting an assortment and abundance of literature authored by African Americans. Yet, such textual abundance and generic range, however welcome and necessary, belie the fundamental tendency of anthology editors to ignore Matthews's assertion in the lecture's first sentence, of all places: "By Race Literature, we mean all the writings emanating from a distinct class-not necessarily race matter; but a general collection of what has been written by the men and women of that Race." Race Literature does not have to be blatantly racial to have special meaning to the Race, as Matthews would have put it. She would have urged us to expand our imagination so that our canonical notions of African American literature would not succumb to axioms of racial authenticity. She would have advised that the mere fact that African American literature even exists, that African Americans over the centuries have demonstrated an unwavering commitment to the idea and act of literary writing, is enough to signify racial progress. African American literature in diverse genres- "History, Biographies, Scientific Treatises, Sermons, Addresses, Novels, Poems, Books of Travel, miscellaneous essays and the contributions to magazines and newspapers"indicate well enough the full range and promise of literary authorship. ${ }^{18}$

In today's terms, I would agree with and advance Matthews's speech by saying that race should not determine too much the idea of African American literature, and that this stance must bulwark against the axiomatic momentum of racial authenticity that has ingrained the political necessity of racial representation to such a degree in African American canon formation that the literary portrayal of African American experiences has become nothing less than a normative proxy for aesthetic beauty. African American literature deserves more than that. It should be appreciated because it instructs and delights us, breaks the rules of the world we live in, and enables us to grapple with the complexities of humanity, which may or may not invoke race. Just as literary art, in general, is what editor Jerome Beaty calls "the very thing humanity can least afford to do without," African American literature should be respectfully defined in the broadest way possible: as the literature written by those who identify themselves as African American, but whose ambition to cre- 
ate art that touches many readers, sometimes regardless of race, is equally meaningful, if not more, due to the enormous historical political burden of racial representation that African American writers have had to bear. ${ }^{19}$

Along these lines, Toni Morrison delivered the keynote lecture at the "Race Matters" conference, held at Princeton University in April 1994, urging our sensitivity to valences of literary creativity including but also beyond race. The Nobel Laureate described her vision of literature in terms at once "race-specific," free of "racial hierarchy," and celebratory of American cultural nationality: "I have never lived, nor have any of us, in a world in which race did not matter. Such a world, one free of racial hierarchy, is usually imagined or described as dreamscape-Edenesque, utopian, so remote are the possibilities of its achievement. ... I prefer to think of a world-in-which-race-does-not-matter as something other than a theme park, or a failed and always-failing dream, or as the father's house of many rooms. I am thinking of it as home." ${ }^{20}$ Morrison's imagination of "a-world-in-which-race-does-not-matter" does not perpetuate a historical denial about "race matters" but actually attends to their historical realities and complexities, to how they bear on contemporary humanity, even as she aspires to create literary worlds challenging the dominance of race.

Let us put Morrison's words in the broader context of her oeuvre to realize their gravity. Her novels and essays have always asserted the significance of race, but she has also been concerned with the tendency of race to determine too much and reduce the complexity of human identity, relations, and culture, especially as portrayed in African American literature. In her 1989 essay "Unspeakable Things Unspoken: The AfroAmerican Presence in American Literature," Morrison interrogates the assumptions and definition of African American literature: "The question of what constitutes the art of a black writer, for whom that modifier is more search than fact, has some urgency. In other words, other than melanin and subject matter, what, in fact, may make me a black writer? Other than my own ethnicity-what is going on in my work that makes me believe it is demonstrably inseparable from a cultural specificity that is Afro-American?"21 Neither Morrison nor I would discount the fact that, in some way, race matters to us all. Yet, in confronting that fact, in embracing the political salience of canons of African American literature, we should also acknowledge and contribute to that large and ongoing conversation spurred by the fundamental question, "What is African American literature?"22 
Morrison's 1998 novel of postmodern hermeneutics, Paradise, also defies the conventional readings of American literature by complicating both "blackness" and "whiteness" in literary characterization. In explaining the racial ambiguity of characterization in this novel-such as its refusal to disclose conclusively the racial identities of the female protagonists-Morrison provides insight not only into her rather unheralded (in comparison to her novels) 1983 short story "Recitatif" but also into her long-standing philosophy about the literary identity of race and about the nature of readers: "The tradition in writing is that if you don't mention a character's race, he's white. Any deviation from that, you have to say. What I wanted to do was not to erase race, but force readers either to care about it or see if it disturbs them that they don't know." ${ }^{23}$ The character is "white" not because of the presence but, rather, because of the absence of racial markers. The lack of racial information (or the underdetermination of race) has been just as successful in defining "whiteness" as the excess of racial information (or the overdetermination of race) has been in defining "blackness." Into that void of identification constitutive of whiteness, according to Morrison, readers often project their usual imagination of universal humanity as "white" humanity. Ironically, Morrison complicates the role of race in literary reading and writing to such a degree that she unsettles the idea of African American literature, even as she has historically been and continues to be celebrated in anthologies and in the public at large as its most accomplished representative.

Years ago, when I edited African American Literature beyond Race, I was hoping to devise an alternative to the conventional anthology, presenting intriguing works by canonical African American authors that, over the course of time, consistently became noncanonical. I was seeking to explain how race, representation, authenticity, genre, canon, and tradition factored - and still factor-into the way scholars read, anthologies organize, instructors teach, and students learn African American literature. And I was attempting to take one step toward minimizing the neglect of African American literature experimenting with nonnormative ways of representing race and the real world. Hence the title and even the mere structure of African American Literature beyond Race were loaded with political meanings: the word beyond, to repeat an earlier point, did not necessarily assert an optimistic belief that we could advance beyond race in our world. To do so would be naive, forgetting the persistence and predominance of racism that continues to cripple African Americans at the most fundamental social, educational, economic, and political levels. And to do so would be ignorant of the historical and ongoing roles of 
African American literature in indicting racism, if not also redressing it in actual readers. Nonetheless, the 2006 anthology hoped to force prevailing canon formation to account for African American authors who wrote, or wished to write, literature beyond race. Today, the challenge for anthologists, myself included, is partly to remain aware that readers today may be more ready than ever to understand the literary problems and possibilities of a "postracial" era. That means being prepared to loosen the ideological straightjacket of racial authenticity and representation that has been restraining the African American canon from expressing itself in more ways than one.

Notes

1. The current complement to the stated anthology of African American literature is Gene Andrew Jarrett, ed., A Companion to African American Literature (Malden, MA: Wiley-Blackwell, 2010). For details about the current state of American literary studies, see the collection of thirty-three scholarly essays edited by Caroline F. Levander and Robert S. Levine, A Companion to American Literary Studies (Malden, MA: Wiley-Blackwell, 2011).

2. Henry Louis Gates Jr. and Nellie Y. McKay, "Preface," The Norton Anthology of African American Literature, ed. Gates and McKay (New York: W. W. Norton, 1997), xxvii-xli, on xxxvi.

3. Gates and McKay, "Preface to the Second Edition," The Norton Anthology of African American Literature, ed. Gates and McKay (New York: W. W. Norton, 2004), xxix-xxxiii, on xxx.

4. Michael C. Dawson, Black Visions: The Roots of Contemporary African-American Political Ideologies (Chicago: University of Chicago Press, 2001), 4.

5. Gates and McKay, "Preface to the Second Edition," xxx.

6. Ward Connerly, "Where 'Separate but Equal' Still Rules," New York Times (May $8,2000)$.

7. Katya Gibel Azoulay opposes "the essentialist reification of race and agree[s] that race operates as a metonym of culture at the price of ideology" ("Outside Our Parents' House: Race, Culture, and Identity," Research in African Literatures 27, no. 1 [Spring 1996]: 129-42, on 129).

8. I elaborate these issues in my new book, Representing the Race: A New Political History of African American Literature (New York: New York University Press, 2011).

9. William Howells, "Life and Letters," Harper's Weekly: A Journal of Civilization 40 (1896): 630.

10. I describe this story and its implications in chapters 1 and 2 of my earlier book, Deans and Truants: Race and Realism in African American Literature (Philadelphia: University of Pennsylvania Press, 2007).

11. For the quotation and its context, Matthew Guterl, introduction, "York Beach [by Jean Toomer]," in African American Literature beyond Race: An Alternative Reader, ed. Gene Andrew Jarrett (New York: New York University Press, 2006), 143-46. 
12. "Forum: What Do We Need to Teach," American Literature 65, no. 2 (June 1993): 325-61, on 326. "What Do We Need to Teach" is a forum in which several scholars discuss the academic and cultural politics of the anthologization or canonization of American literature.

13. John Guillory, Cultural Capital: The Problem of Literary Canon Formation (Chicago: University of Chicago Press, 1993), 5.

14. The second edition of The Norton Anthology of African American Literature, for example, states that it attempts "to make the canon of African American literature accessible to teachers and students" and "essential for the permanent institutionalization of the black literary tradition within departments of English, American Studies, and African American Studies" (Gates and McKay, xxix).

15. See Jarrett, ed., African American Literature beyond Race.

16. Booker was born in 1969 and Obama in 1961; Booker earned his degrees from Stanford University, Oxford University (as a Rhodes Scholar), and Yale University Law School, and Obama earned his from Occidental College, Columbia University, and Harvard Law School.

17. Peter J. Boyer, “The Color of Politics," New Yorker (February 4, 2008), 38-51, on 38.

18. Victoria Earle Matthews, "The Value of Race Literature," Massachusetts Review (Summer 1986): 169-85; first quotation on 185 and the second two on 170.

19. Jerome Beaty, "Foreword," The Norton Introduction to Literature, Shorter 8th edition, ed. Beaty (New York: W. W. Norton, 2002), xxxii.

20. Toni Morrison, "Home," The House That Race Built: Black Americans, U.S. Terrain, ed. Wahneema H. Lubiano, 1st ed. (New York: Pantheon Books, 1997), 3-12, on 3.

21. Toni Morrison, "Unspeakable Things Unspoken: The Afro-American Presence in American Literature," Michigan Quarterly Review 28, no. 1 (1989): 1-34, on 19.

22. In We Wear the Mask Rafia Zafar declares that "critics of African American literature must at some point wrestle with the question of what makes a writer, or her texts, black. Can African descent alone establish a writer's membership in the canon of African American writers?" (6). In Authentic Blackness J. Martin Favor pursues this idea from another angle: "Does a person's racial categorization, the classification of the subject as black, white, or other, necessarily lend a 'racial' character to that person's cultural work?" (5). Finally, Claudia Tate puts the question succinctly in Psychoanalysis and Black Novels: "What constitutes a black literary text in the United States? Must it be written by, about, and/or for African Americans?" (3). See Rafia Zafar, We Wear the Mask: African Americans Write American Literature, 1760-1870 (New York: Columbia University Press, 1997); J. Martin Favor, Authentic Blackness: The Folk in the New Negro Renaissance (Durham: Duke University Press, 1999); Claudia Tate, Psychoanalysis and Black Novels: Desire and the Protocols of Race (New York: Oxford University Press, 1998).

23. Morrison, quoted in Shelley Fisher Fishkin, "Desegregating American Literary Studies," Aesthetics in a Multicultural Age, ed. Emory Elliott et al. (New York: Oxford University Press, 2002) 121-34, on 124-25. 


\title{
James W. Smethurst
}

\section{“LET THE WORLD BE A BLACK POEM"}

\author{
Some Problems of Recollecting and \\ Editing Black Arts Texts
}

My entrée into editorial theory was the direct result of my interest in cultural history and the practical problems of presenting and teaching my work on the Black Arts Movement of the 1960s and 1970s, including selecting, assembling, and contextualizing texts for a Black Arts reader with my coeditors, John Bracey Jr. and Sonia Sanchez, over the last few years. These problems arose as I researched and wrote a history of the origins of Black Arts. One major problem I have often had when I talk about my research, and the Black Arts Movement generally, with colleagues at the University of Massachusetts beyond those in my department, interested scholars who are not Black Arts specialists, students, and potentially interested people outside academia, is that so many of the key texts of the movement are out of print despite a growing body of criticism and literary and cultural history examining the movement. The relative handful of frequently anthologized and cited pieces by a very small number of Black Arts authors often give a distorted or one-sided view of Black Arts. As a result people feel like either they know nothing or they know everything they need to know about this subject-neither of which makes for a productive intellectual dialogue. Until very recently, even much of the best scholarship on African American literature of the 1960 s and 1970 seemed to assume that readers somehow knew and basically understood the shape and scope of Black Arts, allowing for more narrowly focused studies, when the difficulty of actually reading a truly representative sample of texts from the movement was great unless one had access to a major research library and the time and energy to essentially put together a sort of makeshift anthology via photocopy, scan, PDF, and so on, or assemble one in one's head. As I will mention again at 
the end of this essay, such improvisatory and increasingly legally dubious editing was a necessary and potentially risky task for anyone who wanted to teach the Black Arts Movement for many years.

In addition, certain aspects of the Black Arts Movement cause me to think more deeply about textuality, the material production of texts, and the relation of texts to performance than I might have done otherwise. One of the most perceptive scholars of the Black Arts Movement, Mike Sell, persuasively argues that it was "a textually supported anti-textual movement." That is to say that Black Arts (and Black Power) significantly came to be understood as a national phenomenon through the circulation of printed texts, including such journals as Liberator, Freedomways, Negro Digest (later Black World), Black Dialogue, Soulbook, Black America, Black Theatre, and the Journal of Black Poetry, such anthologies as Amiri Baraka and Larry Neal's Black Fire (1968) and Stephen Henderson's Understanding the New Black Poetry (1972), and the broadsides and books of such black presses as Broadside Press, Third World Press (now the oldest literary black publisher in the United States), Lotus Press, Journal of Black Poetry Press, and Jihad Productions. In fact, one can make the claim that these journals and presses were the most significant and enduring institutions of the Black Arts Movement. Certainly, they make up the most valuable documentary record of the movement now.

At the same time, as Sell notes, there was often a privileging of the oral and of a performance ethos, often linked in poetics and practice with black music. ${ }^{2}$ Not only was performance in almost every conceivable public space where black people gathered a major feature of Black Arts poetry, often in hybrid conjunction with other genres and media (especially music, dance, drama, and the visual arts), but poetic (and even critical/theoretical) texts often drew on the resources of African American rhetoric and performance and thematized performance even if those texts were not actually performed. It might be true, as Lorenzo Thomas claims, that the formal arrangement of Black Arts poetry on the page was often a sort of score for performance. ${ }^{3}$ However, it was in fact not until some years after its initial publication that Sonia Sanchez read "a/Coltrane/poem" in public_and then only upon request. She recalls that the performance was a success, but that it took some considerable effort to translate aloud the poem's lineation and spatial arrangement of words designed to recreate a sense of John Coltrane's chordal explorations on the page. ${ }^{4}$ Similarly, though the poet A. B. Spellman's work was deeply inflected by the performance of such post-bebop jazz musi- 
cians as Sonny Rollins, John Coltrane, Ornette Coleman, and Cecil Taylor, Spellman never felt comfortable as a public reader and wrote for the printed page. In short, one aspect of the Black Arts Movement is that it was, in general, extraordinarily concerned with investigating the text (and the presentation of the text to an audience) and its relationship to the outside world, especially language and expressive culture beyond the printed page, seeing that relationship as a sort of process rather than a product suitable for framing. I, in turn, felt obligated to take the text and its presentation and circulation as seriously as did the participants in the movement.

As a result of this concern and the problems I encountered in discussing and teaching the movement, it occurred to me that a Black Arts reader that included key belletristic, critical, and theoretical texts, as well as crucial paratexts, would be a really helpful scholarly and pedagogical tool that would have considerable appeal beyond academia. I have given some thought to the challenges of creating such a reader, and this essay will focus on these challenges. It is my hope that it might in some small way be helpful not only in inspiring other readers and anthologies but also in understanding and teaching the movement.

The challenges to putting together an effective Black Arts reader fall into three basic categories: logistical, contextual, and aesthetic. Obviously, these categories are interrelated and not unique to the Black Arts Movement. Some of the examples that I will cite could easily be moved from one category to another.

The fundamental logistical problem is that a large number of important Black Arts texts (especially the many that only appeared in regionally or locally based journals, newspapers, or small press chapbooks and broadsides) are now hard to find. Others, like most of the work of the Chicago-based poet Amus Mor (whose jazz poetry had an enormous influence on the diction, rhythm, and reading styles of Amiri Baraka, Larry Neal, and other major Black Arts poets), was transmitted primarily orally through readings and other sorts of performances-though it is possible to find various sorts of recordings or transcripts of this material. ${ }^{5}$ This may seem obvious, but the challenge for an editor is not to take the easy way out and publish the usual subjects from more readily available books and journals, reinforcing our sense of what is "major" and what is "minor" (if one knows that the minor exists at all) without sufficient empirical evidence on which to base that judgment. And, one has to admit, in assembling anthologies this is a challenge that we 
often fail to meet. Take the Harlem or New Negro Renaissance, for example. How many anthologies draw on the same handful of books and journals (usually The Crisis, Opportunity, and The Messenger) and ignore significant, but more locally based (and non-New York-based) journals, such as Boston's Saturday Evening Quill? As a result, important writers of the New Negro Renaissance, say, Waring Cuney (along with Langston Hughes and Sterling Brown, an early innovator of the blues poem), many of whose most interesting early poems appeared in the Quill, are slighted or misrepresented.

One of the most important (and frustrating to scholars and would-be anthologists) aspects of the Black Arts Movement was its wide regional distribution and diversity. Again, as scholars have increasingly made us aware in recent years, many earlier African American cultural movements had a far wider geographical reach than such descriptors as "Harlem Renaissance" or "Chicago Renaissance" would suggest. But I am not aware of any black art movement-or even any U.S. art movement-that had the same sort of nationwide grassroots distribution as did the Black Arts Movement. There was virtually no city or campus in the United States with any appreciable number of black people where there was not a Black Arts bookstore, theater, community school, writer's workshop, art gallery, dance company, musicians' collective, poetry reading series, magazine, or newspaper. Often there would be many of these institutions. The movement even touched many smaller towns. This was brought home to me while I taught at the University of North Florida in Jacksonville. There I had a student in her forties who had been a part of a black theater group in Cross Creek, Florida (the small, unincorporated rural town famed mostly as the setting of Marjorie Rawlings's The Yearling), while she was in high school during the early 1970s. She saw this group as very much part of the black cultural upsurge of that moment. In short, I felt, if it was happening in Cross Creek, it was happening practically everywhere that African Americans lived in appreciable numbers.

While one could trace ideological, aesthetic, and infrastructural continuities and connections between many of these institutions, there were considerable local differences based on regional histories, demographics, cultural traditions, political formations, economics, and even the personalities of leading Black Arts activists. It made a difference, for example, for Black Arts and Black Power founders in the Northeast, that Malcolm X was a regular and surprisingly accessible presence in Harlem. One would miss something vital about the movement, too, if work from 
the important New Orleans-based BLKARTSOUTH (and its journal Nkombo), which covered a region in which the legacy of Jim Crow (and the mass movement that arose to fight it) deeply inflected Black Arts and notions of African American self-determination, were missing.

I suppose the contextual problem is also obvious and certainly not restricted to the texts of the Black Arts Movement. One of the inherent challenges for putting together anthologies is to figure out how to select and frame material so as not to distort or misrepresent whatever category or classification of literature it seeks to present while keeping the selections to a manageable length. There is never an entirely satisfactory solution to this problem. However, at times the distortions of the material and the movement, formation, or period represented by the material that occur are extremely irritating, though all too common. To take a non-Black Arts example, it has always seemed to me sort of criminal to constantly anthologize as a short poem William Carlos Williams's "The Red Wheelbarrow" without the rest of section XXII of Spring and All"The Red Wheelbarrow" really is an entirely different thing seen in the explosion of words that characterizes the rest of section XXII. Similarly, a poem like Langston Hughes's "Harlem" takes on a much different cast when placed within the frame of the rest of the poems of Montage of a Dream Deferred where it appeared in 1951 as an untitled part of a long lyric sequence.

Historical framing is absolutely crucial in the case of the Black Arts Movement, especially given the various claims about black "racism" and black nationalism that have emerged frequently throughout the Obama administration - not to mention even longer-standing, and often liberalleft, attacks on "identity politics" that cite Black Arts and Black Power as the beginning of social and cultural decline. When students (and others) read some central Black Arts texts, say, Amiri Baraka's "Black Art," they have a tendency to think that these works are crazy-or else they do what too many Black Arts and Black Power activists (and others) do retrospectively - which is try to pound the square peg of Black Arts radicalism into the round hole of today's sensibilities, to try to smooth out the contradictions and complexities of the movement and the moment. The challenge is not only the profanity, the violent rhetoric, the homophobia, the misogyny, and the anti-Semitism of a number of Black Arts texts (though homophobia, misogyny, and anti-Semitism are not as ubiquitous and unchallenged with the movement as received wisdom often accepts), but also the belief that radical social transformation was 
not simply possible but imminent. I find that even my most politically engaged, radical, and/or black nationalist students today do not expect sweeping social change or a liberated African American state any time soon-however much they agree with the political critique of U.S. society contained within Black Arts/Black Power texts.

While editors and readers inevitably read back from their own moment (and, in fact, the significance and even the value of the anthologized period, movement, genre, and so on, are always inextricably linked to the sensibilities and concerns of the moments in which anthologies appear and continue to be read), still the challenge is to frame the texts, to provide the scholarly introductions and apparatus, so as to explain how powerful, often brilliant artists and intellectuals could arrive where they did aesthetically and ideologically while not glossing over the contradictions and even ugly aspects of the movement. What does one make of a poem like Sonia Sanchez's "TCB," which seems like an effective poem to me even though it largely consists of the repeated phrase "wite/ motha/fucka"?6 In other words, the Black Arts Movement was not, in general, a sociopathic cult; neither was it an Upper Westside Democratic Reform Club in New York City-though one can find characterizations now that make it seem like both (and even though the movement did include some reformers and some sociopaths).

One runs into an aesthetic problem here. On one hand, few of us undertake an anthology of literary texts unless we like a large number of the texts on some level-usually a sense of "importance" alone is not enough for us unless we think the text is good. Otherwise, if it were simply a question of cultural importance, as Jane Tompkins pointed out in Sensational Designs a quarter of a century ago, Moby Dick and many other canonical texts of the "American Renaissance" would have vanished from the earth (which Moby Dick more or less did for decades before its critical revival in the twentieth century) or at least been taught far less frequently than Uncle Tom's Cabin, which was vastly more widely circulated, and socially and even culturally more influential than Melville's novel. ${ }^{7}$ Still, despite the influential and now long-standing efforts of Tompkins and other champions of nineteenth-century sentimental literature to rethink what is "good," and to remind us how value is connected to race, gender, class, and the politics of a certain moment or series of moments, such as the Cold War, I have not yet encountered any campus where Stowe's novel is more likely to be taught than Melville's-and certainly none where many professors are likely to claim that Uncle Tom's Cabin is superior to Moby 
Dick. The point here is that however forewarned and forearmed we are about our possible aesthetic and ideological prejudices and shortcomings, we tend to include work that we think is aesthetically or artistically valuable, for the most part-and did so even before the critical return to "beauty." For example, one can look at the various anthologies of the Harlem Renaissance and find virtually no work by the Garveyite nationalist poets who published in the pages of Negro World despite the fact that they often had more readers than the poets who published in The Crisis, Opportunity, and The Messenger. Why? Well, in significant part because most of us would consider the work of these Garveyite poets to be stale, trite, old-fashioned, certifiably not modernist-in short, bad. We can also see this at work in African American literary anthologies (excepting Call and Response: The Riverside Anthology of the African American Literary Tradition), where, until recently, the selections of the Black Arts Movement have been generally those that most conform to almost a new critical vision of what a good poem or story should be. For instance, if you look at the Sonia Sanchez selections in the Norton Anthology of African American Literature, you will find that, for the most part, the editors chose poems that were among the least formally radical in lineation, diction, syntax, and so on. In other words, there is a pronounced tendency to include poems that conform most to our sense of what is aesthetically good, which can skew our sense of an author's larger corpus and can slight important writers who we don't feel are very good. To some extent this may not only be a problem of taste but also one relating to the original logistical problems I cited earlier-important writers who have never published with a mainstream commercial or university press, such as Askia Touré or Amus Mor, or who lived outside the main loci of literary and academic production, such as Lorenzo Thomas in Houston, Eugene Redmond in East St. Louis, or Norman Jordan in Cleveland, tend to be under-represented (if represented at all) in most general African American literature anthologies-again, the Riverside (within the limits of space constraints) is largely an exception. Of course, an anthology (and the long-term importance of a literary moment or movement) is hard to sell to publishers, teachers, students, and general readers if you are not able to argue that the bulk of the material contained within it is aesthetically valuable.

Another contextual problem is that the format of most anthologies is not really congenial to the original format of most Black Arts publications. There were a significant number of Black Arts anthologies, such as 
Baraka and Neal's 1968 Black Fire and Dudley Randall's 1971 The Black Poets, and individual works by important Black Arts writers, such as Baraka, Nikki Giovanni, and Ishmael Reed, published by so-called mainstream commercial presses. You might call these books that looked like literary books as we now understand them (the mainstreaming of the graphic novel notwithstanding)-basically pages of type with few or no images between two covers. However, as I mentioned before, a tremendous number of Black Arts texts were printed by African Americanowned, African American-operated presses, such as Broadside Press, Third World Press, Jihad Publications, Journal of Black Poetry Press, Nkombo Publications, Lotus Press, and so on. Obviously, there is a different feel to this sort of publication.

And beyond the fairly intangible question of feel, there is the far more concrete issue of cover art and often internal illustrations that are far more crucial to the framing of the text than was and is generally the case with large-press publications. Again, this is not a new problem. Even when speaking of large-press publications, it is worth recalling, as Cary Nelson does in Repression and Recovery, that there was a time when such cover art and illustrations meant a lot more than they do today. For example, like Nelson, I have always thought the decisions not to include the illustrations of Charles Cullen in the anthology of Countee Cullen's work, My Soul's High Song (1990), and to omit the drawings of E. Simms Campbell from the version of Sterling Brown's Southern Road contained in The Collected Poems of Sterling A. Brown (1980), to be ill-considered. ${ }^{8}$ Paul Laurence Dunbar's books that combine his poetry with the photographs of the Hampton Institute Camera Club, too, have a far different impact than those collections that simply reproduce the verbal texts, such as Joanne Braxton's The Collected Poetry of Paul Laurence Dunbar (1993) - as grateful as I am to Braxton for making it possible to teach Dunbar in an effective way. However, I think that in the case of the Black Arts Movement, such framing was an even more crucial aspect of the reader's experience in approaching these texts.

This raises the issue of Black Arts aesthetics. Again, as many scholars have noted, one hallmark of the Black Arts Movement was that it was multimedia, multigeneric, and oriented toward performance. One can overstate the oral/performance nature of the movement-there were authors, such as the aforementioned A. B. Spellman, who were much more comfortable with the printed page. And, again, given the geographical dispersion of Black Arts, it would have been almost impossible to imag- 
ine it as a national movement without the printed texts of publishers like Broadside Press and Third World Press and of journals like Black World and Journal of Black Poetry binding it together, however loosely. Still, it is fair to say that the Black Arts Movement, whether one is talking of literature, the visual arts, music, or theater, in general tried to engage a mass audience in public places, streets, housing project courtyards, theaters, bars, community centers, parks, and so on. These performances were often hybrid, multimedia presentations as in, say, performances by Sun Ra and his Arkestra or by the Los Angeles-based Pan Afrikan Peoples Arkestra, which mixed dance, poetry, theater, the visual arts, and music-often simultaneously. There were many records of Black Arts music-literature performances issued-though most are hard to get hold of now. Black Arts texts were often constructed in such a way as to convey this sense of orality and generic hybridity even when, as in the case of Sanchez's "a/Coltrane/poem," it might have been some years, if ever, before the poem was actually performed.

Once again, I suppose that this is an old problem. Reading Allen Ginsberg's "Howl" on the page is much different from hearing a recording of him declaiming in the 1950 s while members of the audience shout "Go"-and Ginsberg himself claimed that his inspiration for the long lines of "Howl" was bebop-era jazz soloing. However, again, I think that the Black Arts Movement is distinguished by the depth of centrality of performance as a practice and as a model to its art. After all, the New York poets, such as Frank O'Hara, Barbara Guest, and John Ashbery, did do a considerable number of poetry readings, but even in their cases, they were or are relatively indifferent readers for the most part, and their texts existed primarily for the printed page. The same cannot be said for many Black Arts writers. In fact, if one listens to recordings of Amiri Baraka from different points in his career, one might track his evolution from New American/Beat/New York poet to Black Arts activist from the late 1950 s to the mid-1960s by his improvement as a performer of his own work. To my ears at least, Baraka's reading on a 1959 recording of "Freedom Suite (For Sonny Rollins and Franz Kline)" is relatively tentative; his reading of "Black Art" on the 1965 Jihad Productions album Sonny's Time Now captures his emergence as one of the great performers of poetry in our time. ${ }^{9}$ So, obviously, capturing this crucial performative aspect of the movement presents major problems for the would-be Black Arts anthologist.

What does this mean concretely for the Black Arts anthologist? It 
means, again, that the scholarly framing and criteria for making the selections are crucial. One obvious thing is to make sure that a wide range of Black Arts texts, geographically, aesthetically, ideologically, and institutionally, is represented. I say obvious, but again, just because it is obvious doesn't mean that it always or even often happens. This part is relatively easy. It does require work, time, and a certain amount of judgment based not only on one's sense of literary value but also on a familiarity with the cultural discussions and debates of the movement. Consulting with living Black Arts veterans, such as Sonia Sanchez, Jayne Cortez, Amiri Baraka, Kalamu ya Salaam, Haki Madhubuti, Woodie King, Barbara Watkins, Askia Touré, Johari Amini, and Marvin X, about what they saw as the key journals and texts, is essential in honing that judgment. And again, one of the crucial challenges is to avoid removing the rough edges of the movement without making it seem like a freak show-or to recall that if it is freaky in the light of today's political and cultural sensibilities, it made a lot of sense in that era of national liberation and the Cold War national security state.

The question of what sort of scholarly apparatus one creates is key to justifying and understanding the sort of choices one will have to make if one is going to accurately capture the Black Arts Movement and moment. The issue of such scholarly framing and apparatus is fairly simple in theory, if not in practice. What is important is the recognition that strong opinions about the Black Arts Movement and the Black Power Movement are legion, but serious scholarship is still relatively thin, if rapidly growing. That means that, unlike the anthologist of the Harlem Renaissance, the Black Arts anthologist will need to spend much more space defining and framing the movement. In the case of the Black Arts reader that I am coediting with Sonia Sanchez and John Bracey, we have not only included such elements as an introductory overview of the anthology and the movement and a timeline, but also introductions to the different sections of the reader written by Black Arts veterans who were particularly active in the genres covered by the sections. We have also incorporated a number of reminiscences by Black Arts activists giving a sense of the felt experience or everyday texture of, say, Black Arts theater or poetry performance in the 1960 os and 1970s. One lasting contribution of these introductions and reminiscences is that they offer an immediate sense of the movement by its veterans who, at the same time, have had some decades to reflect upon and process their experiences. We have also included a section of manifestos, statements of purpose, and vari- 
ous sorts of paratexts (often aesthetic and political declarations) that accompanied publications by Broadside Press, Third World Press, and the other presses, newspapers, and journals of the movement.

The system of organizing the selections is a crucial aspect of framing and could be approached variously. One tried-and-true method is to do it generically-essays, poetry, fiction, drama, and so on-which is how we chose to arrange our reader. In fact, this was how such seminal Black Arts era anthologies as Black Fire and Black Voices were typically organized. Another method would be some sort of chronological order with the notion that this would best display the development of the movement. Another plausible arrangement would be geographical so as to demonstrate the significant regional variation of the movement-and to ensure adequate regional representation (an issue that still provokes Southern Black Arts veterans today). All have their drawbacks. A generic ordering tends to obscure the essentially multigeneric, multimedia hybridity and generic interchange of the movement. Chronological order tends to flatten out or disguise geographical distinction. Geographical organization obscures the genuinely national aspects and interconnections of the movement and makes tracing the evolution of the movement over time more difficult. And what do you do with the many Black Arts figures, such as Jayne Cortez, Tom Dent, Lorenzo Thomas, Askia Touré, John O. Killens, Sonia Sanchez, and Amiri Baraka, who over time play significant roles in two or more regions? As I mentioned before, in the end we followed the generic model-though through our use of the various introductions and reminiscences we tried to get across a sense of the cross-generic, multimedia nature of the movement as well as its historical development.

The most difficult aspect of context bleeds into the question of representing Black Arts poetics and aesthetic practice. One obvious move, which has become a standard of African American literature anthologies (and now other sorts of poetry anthologies) is to include an accompanying $\mathrm{CD}$ with example of writers reading their works. In general, these CDs contain simple poetry readings or else illustrative examples of music and folk rhetorical practices on which the writers draw, say, a Scott Joplin rag, a sermon, or Bessie Smith singing "Backwater Blues." Rarely do you get the sort of music-poetry interface so common in the Black Arts erawith a few exceptions, such as works by Gil Scott-Heron or the Last Poets. Again, it is worth examining whether our sense of genre and medium is more rigid than we might otherwise think. In short, maybe it is a copy- 
right problem, but it seems to me that the recording of Baraka performing "Black Art" with Sunny Murray's jazz group is an essential document for a collection attempting to represent the Black Arts moment.

A more knotty question in terms of producing an anthology that people can actually afford to buy concerns the more visual dimensions of the movement. It is no doubt unrealistic, but it would be wonderful if there could be a CD-ROM accompaniment that included video of say, poets reading with music and dance (say, an Ntozake Shange choreopoem), Sun $\mathrm{Ra}$ in concert, theater performances, documentary, and so on. It seems to me that it would not be too difficult to at least have a CD-ROM with PDF files reproducing how the original texts on the page, covers of books, chapbooks, and magazines, and so on, actually looked.

In the end here, what I am talking about is not simply the editing and anthologizing of Black Arts texts but really an approach to teaching them. It is, in fact, basically how most people I know who do teach these texts approach them. In essence, we have cobbled together out of various materials a skeletal version of a Black Arts reader trying to capture its ideological, geographical, and aesthetic diversity. In that sense we have all had to be anthologists if we wanted to teach African American literature and culture of the 1960s and 1970s. We have all had to think deeply about the nature of Black Arts texts and their relationship to other sorts of expressive culture.

One of the things that almost all of us have discovered is that, contrary to what had been the dominant or received wisdom about Black Arts in the academy when I went to graduate school (the early and mid1990s), the movement was not theoretically averse, but intensely theoretical. Larry Neal did not have to read Jonathan Culler to find out about structuralism - he had already encountered it as a graduate student in folklore at the University of Pennsylvania in the early 196os. Black cultural and political activists in the early and mid-196os studied psychoanalytic theory (via Frantz Fanon) and the work of Antonio Gramsci and other Marxist thinkers as well as a range of nationalist and postcolonial/ anticolonial theorists in the study groups and workshops that were major incubators of Black Arts. They also created their own homegrown versions of reader response theory, insisting that meaning could not exist independent of an audience and that the audience was an essential feature in creating meaning-hence, one of the reasons for the emphasis on a performance ethos in which artist, work, and audience are intimately bound. While many aesthetic and ideological issues were taken up, none 
seemed as pressing as discussing what made a text "Black" and what, in fact, a text was and what it was for. So in the end, my desire to teach the Black Arts Movement (and to write a cultural history of its origins and early development) inevitably led me to attempt to create a usable anthology that takes texts and textuality in a manner as serious and nuanced as did most of the participants in the movement themselves.

Notes

1. Mike Sell, "Ed Bullins as Editorial Performer: Textual Power and the Limits of Performance in the Black Arts Movement," Theatre Journal 53, no. 3 (October 2001): 418.

2. Sell, 411-12.

3. Lorenzo Thomas, Extraordinary Measures: Afrocentric Modernism and Twentieth-Century American Poetry (Tuscaloosa: University of Alabama Press, 200o), 211.

4. Author's conversation with Sonia Sanchez, January 15, 2003, Philadelphia, Pennsylvania.

5. For an example of Mor's poetry and performance style, see (or hear) his reading on the record Black Spirits (Black Forum, 1972).

6. Sonia Sanchez, We a BaddDDD People (Detroit: Broadside Press, 1970).

7. Jane Tompkins, Sensational Designs: The Cultural Work of American Fiction, 1790-1860 (New York: Oxford University Press, 1986), xiv-xv.

8. Cary Nelson, Repression and Recovery: Modern American Poetry and the Politics of Cultural Memory, 1910-1915 (Madison: University of Wisconsin Press, 1989), 90-97, 193-94.

Other critics have echoed Nelson in this regard. George Bornstein, like Nelson, points out that the omission of Weinhold Reiss's original illustrations in later reprints of Alain Locke's 1925 The New Negro not only weakens the impact of the anthology but substantially changes its ideological cast as an interracial project (George Bornstein, Material Modernism: The Politics of the Page [New York: Cambridge University Press, 2001], 150-52).

9. Our Souls Have Grown Deep Like the Rivers: Black Poets Read Their Work (Rhino/ Word Beat, 2000); Sunny Murray, Sunny's Time Now (Jihad Productions, 1965). 


\section{Margo Natalie Crawford}

\section{TEXTUAL PRODUCTIONS OF \\ BLACK AESTHETICS UNBOUND}

The paratext of the first book, in African American literature, with the title "Black Power"-Richard Wright's 1954 travel narrative-reframes the frame of slave narratives and makes readers wade in the water before entering the text proper. Instead of the typical words "as written by himself" or "as written by herself," and the former slaves' signatures that almost make the texts legal documents of the mastery of literacy, the paratext of Wright's Black Power deforms mastery. ${ }^{1}$ The layered framing of Black Power includes:

two photographs of Kwame Nkrumah (one with traditional Ghanaian clothing, one with a business suit);

a letter written by Nkrumah, certifying that Wright is "a fit and proper person to be allowed to visit the Gold Coast";

a map of Northwest Africa;

a dedication to "The Unknown African";

the question "What is Africa to Me?" from Countee Cullen's poem "Heritage";

one line from Walt Whitman 's poem 'To a Common Prostitute"; and one sentence, written by Robert Briffault, explaining that all human development is "transmitted social heredity."

The layers in this paratext dramatize a long passageway into the inner space of the text. I indent the middle section because, in this center of the paratext, Wright makes readers move to the unknown, to that which cannot be mapped and framed in the manner of the photographs of Nkrumah and the map of Northwest Africa. As Richard Wright writes about his travel to Ghana, he foregrounds the lack of "Black Power" in Africa and his own discovery that he is African American, not African. 
The paratext introduces the pivot, in this travel narrative, between what is known and what is unknown. The unknowing and skepticism may make the title "Black Power" very different from the meaning of "Black Power" in the 1960 s and early 1970 os Black Power movement. The common ground, however, between Wright's Black Power and the textual production of the Black Arts Movement (the artistic counterpart of the Black Power movement) may be the framing of the physical book itself in terms of what it contains and what it cannot contain. The tension between the bound and the unbound propels readers' travel into the interior textual space.

The 1960 s and early 1970 s Black Arts Movement remains the first African American cultural movement that performed the production of books written specifically for black people. In order to gain a fuller grasp of the role of textual production in the creation of the specific literary traditions that are understood as "African American," we must appreciate the Black Arts Movement's explicit framing of the book as "Black." Even the color of the cover of Black Arts literary texts was often black. The founding of black-owned publishing houses was a vital part of this production of the black book. Dudley Randall founded Broadside Press in 1965, when he created a broadside of his poem "Ballad of Birmingham" that responded to the 1963 church bombing that killed four young African American girls. Third World Press (which remains the largest independent black press) began in Chicago in 1967, when the young poet Haki Madhubuti (Don Lee), with the help of the poets Johari Amini and Carolyn Rodgers, created the first publication with a used mimeograph machine.

How did the Black Arts Movement understand the idea of the black book? The movement made the black book a type of counterpublic, a particular type of public space that aimed to offer a privacy for the ideal black readers. ${ }^{3}$ The movement hailed ideal readers and created desire to "think black" (one of the very titles of one of Haki Madhubuti's poetry volumes). One of the movement's most dramatic examples of the hailing of ideal black readers was the textual production of Amiri Baraka and Fundi Abernathy's In Our Terribleness (1970). The book begins with a full-page mirror image that demands that readers see their face, and the title "In Our Terribleness," inscribed on the face, as readers enter this "long image story in motion." Readers enter black, urban, 1960s, South Side Chicago. The "Black Book," during this movement's reenergizing of black urban space, was the textual production of African Americans' rec- 
lamation of the city as their intimate dwelling place. Toward the beginning of In Our Terribleness, Baraka shapes the book into a guide for ideal black readers' new way of moving through the city. He counsels, "Who inhabits the cities possesses the thrust of life to power. ... Man woman child in a house is a nation. More than them we become large cities that shd have, domes, spires, spirals, pyramids, you need somethin flashy man. Some red and bright green or yr black self. The cities the cities our dominion." As Baraka's words interact with Fundi's photographs, there are "domes" and "spirals" of words becoming more concretely visual and photographs gaining more abstract dimensions. The book itself becomes the binding, bursting at its seams, trying to hold this large "dominion" of black urban style.

This book's interplay of words and images is framed specifically as a "black book" mission in a letter that the Chicago photographer Fundi Abernathy sent to Baraka as they were struggling to expedite BobbsMerrill's publication of In Our Terribleness. Abernathy met Baraka when he and wife Laina temporarily left Chicago in order to be a part of the Spirit House collective in Newark, New Jersey. After Abernathy returned to Chicago and he and Baraka had already completed the manuscript for In Our Terribleness, he sent Baraka a letter expressing his frustration with the publisher Bobbs-Merrill and his commitment to the "Black Book."

Like many Black Arts poems, the letter works written language for its most visual and oral possibilities. The full letter reads:

TO

IMAMU

DIG

TO SUE BOBBS-MERRILL

NO MATTER WHAT

GON DO THAT BOOK

AND FINISH IT CLEAN

NO MATTER IT MEANS

LATER FOR ANY SLOW-MOTION

ideas

of any bodies

THE BLACK ARTIST MOVE SPEEDY

DOING WHATSINEVER is

NEEDY

FAST PASS PAST MOVIN METEORITE 
BLINDING THE PACE OF LITE

WE GO WE OUT O SIGHT

WE BLACK BLACK \& RIGHT

WE GIT TA GETHER GIT OUR GAME UPTIGHT

WE SUE WE SUE WE SUE

\& do \& do the SACRED BOOK

WITH OR WITHOUT ANYBODY YOU DIG!

\& ITS CREATION WILL SIGNAL THE WORLD

ITS GREATEST BIRTH BEGINNING-A NATION

SO BLACK

A NEW WORLD OF IMAMU AMEER BARAKA'S

BEAUTIFUL BLACK CONCEPTION A WORLD

BLACK ART FILLED BLACK WORLD

YOU CAN DIG IT

ITS REAL

Our BLACK BOOK WILL BE THE

WORLD"S GREATEST CREATION

FOR BLACKNESS

MIND MIRROR MAGIC

the Hypnotic force of BLACK LOVE will

conquer UGLINESS AND endure for sure as

do sue do sue do sue do sue do do do do

MASTERS sue due do due sue we we we WEEEEEEEEEEE

BANG! BANG! BANG! Love (Billy Abernathy) Fundi May 5

$1969^{5}$

This letter is similar to the performance poems and broadsides created during this movement, and, like these Black Arts poetic and visual texts, the letter includes a play with the atypical arrangement of words on the page and the use of capitalized letters that make the words approach "poster art," one of the tenets of the movement's central visual arts collective AfriCobra (African Commune of Bad Relevant Artists). Abernathy's emphasis, in the letter, on the mirror and "hypnotic" effect of the "black book" explains why he and Baraka decided to frame this "black book" with a full-page mirror. The opening title page of the book includes a silver mirror surface (that appears to be pasted in an intentionally homemade manner) with the words "In Our Terribleness" engraved in the center. The Black Arts Movement shaped the reading of the black book into ideal black readers' process of imagining that they were looking into 
a counter-mirror, a mirror that countered a dominant, hegemonic lensthe white gaze. Instead of the slave narrative paratext (the documents that authenticate that the narrative "was written by himself," or "written by herself"), this Black Arts Movement paratext replaces the slave narrative's opening certificate of the slave's literacy with the mirror certification that an actual face is reading a book, that the reading process has a materiality.

This materiality is also dramatized in Toni Morrison's preface to the legendary African American text that was given the literal name "The Black Book." This text was published, in 1974, by Random House. It is a collection of words and images that explain the historical trauma and the cultural production of African Americans. Henry Louis Gates Jr. has aptly referred to it as the "the ultimate treasure chest of the black expe-

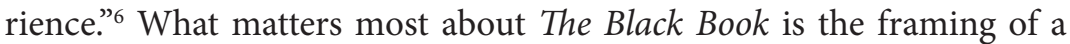
specifically black book as a book that contains an archive, that creates that "treasure chest" effect described by Gates. The Black Book is a surreal collection of slave auction ads, folklore, music lyrics, photographs, minstrelsy posters, a huge range of newspaper stories, color photographs of quilts and other examples of art created by enslaved Africans, and many other texts and images. In the preface to The Black Book (the original preface that also appears in the 2009 new edition), Toni Morrison begins with the words "I am The Black Book" and ends with the words "I am not complete here; there is much more, / but there is no more time and no more space ... and I have journeys to take, / ships to name, and crews."7

With these last words, Morrison channels the words of the slain Black Arts Movement poet Henry Dumas. Six years after his murder (by a white police officer), Morrison makes his poetic words the beginning and the end of The Black Book. His words are not only the last words in the preface; they are also the final words framing (on the last page of the book) an untitled, undated photograph of an elderly African American man, wearing a tattered suit, sitting on a porch chair, and looking at the camera's lens with an expression that is difficult to read. Is it contempt, expectancy, or simply unknowable? The unreadability of this facial expression performs the lack of closure of The Black Book. Morrison's prefatory words linger: "I am not complete here."

The Black Arts Movement "Black Book" also has this lack of closure. Consider the final words of In Our Terribleness: "Now get up and go." It matters that The Black Book is published as the Black Arts Movement is ending. The editors of The Black Book collected words and images that 
define the "black" experience. The Black Arts Movement was invested in a similar collection process and also in black collection of blackness, as opposed to what the movement saw as the dominant (white) culture's collection of African American culture. The black books, produced by the Black Arts Movement, were the textual performance of the antitext, the performance of writing and producing books that would be too action-oriented to be held as a precious object of highbrow capital.

Unless we remember the word and image interplays in the Black Arts books, we forget the role of process-oriented conceptual art in these books that were performing antitextuality. The inclusion of the images allowed the Black Arts Movement to dramatize the pictures embedded in words and words-as-pictures, as the movement attempted to situate the black aesthetic as that which W. J. T. Mitchell refers to as the "imagetext." When the visual arts collective AfriCobra made "mimesis at midpoint" one of their prime tenets, in addition to "lettering" (the need to add words to murals and other visual art), the movement was conceptualizing the hybrid form of the imagetext as the collective mission of creating an alternative understanding of text. ${ }^{9}$ The use of the mirror at the beginning of In Our Terribleness makes readers see themselves as a part of the black book. The black book incorporates the black body. We see this same emphasis on the intertwining of book and body when Baraka writes the word gesture on the right-hand margin of one page. The word gesture appears at the very edge of the page where readers would turn the page. The black book not only hails black readers; it also incorporates the bodily gestures of readers. The open text produced by readers is dramatized in Black Power coloring books. These coloring books (published by Black Arts Movement presses, such as Third World Press) emblematize the counterliteracy. These coloring books echo Morrison's words in The Black Book, "I am not complete here." The coloring process, the filling in, and the collaboration required from the readers made these coloring books antitext acts of becoming like Black Arts performance poetry. Black Arts poets, as well as Black Arts visual artists, made words into visual signs. The poets and visual artists dramatized the visual shape of language but they also used the visual to dramatize how lines that create clear shapes also morph into the shapes that cannot be named.

Black Arts word and image interplays show that the writers and visual artists were thinking about lines (verbal lines and drawn or painted lines) as the means for the literal production of more space between the lines. The 1968 Third World Press broadside of Don Lee's poem "for 
black people (and negroes too): a poetic statement on black existence in America with a view of tomorrow" is one of the most pronounced examples of this play with the space between lines. The cover of this broadside was designed by the AfriCobra artist Omar Lama. The cover image is a profile of a woman. Geometric shapes (an array of lines) form the profile and the area surrounding the profile. The force of this drawing derives from the artist's ability to create the aura of stained glass without using any colors other than the black lines and the white paper. This thick paper broadside is folded so that the cover image opens up to two pages of Don Lee's poetry. The poem, like many Black Arts performances, performs the purging of the dominant ideology that the movement ties to whiteness. When the poem is framed by Lama's drawing, the poem's "view of tomorrow" may seem much more concrete than the abstract geometric forms in the drawing. If the drawing is comparable to a precoloring template for a stained-glass design, Lee's poem delivers concrete words that aim to shatter the glass of Catholicism (and the whiteness it signifies in the poem). Lee's worrying of the lines of the Catholic prayer "Hail Mary" into "Hell Mary" drains the color out of the stained glass Catholic church image, and the form discovered after the purging can be visualized through the broadside cover image of the pre-stain. When connected to the drawing, the poem's "view of tomorrow" is a shape waiting to be colored, the Black Arts Movement hailing of more lines that can enclose areas and create space. Half of the woman's profile (the darker part of the image) is foreground but the other half merges with the background. The profile of the woman could tilt outward or inward, away from or deeper within the background of geometric forms. The tilt to the left would make the real face emerge, outside of the abstract forms. The tilt to the right would make the real face become entirely abstract. Lama was practicing the AfriCobra aesthetic principle of "mimesis at mid-point." Lee's poem also has this mid-point tension.

As the Black Arts Movement made "Black" into such a powerful sign, it became an abstract sign, like the shape of a traffic stop sign that can be recognized in the distance even if the color of the sign cannot be seen when visibility is poor. Signs become abstract shapes when they are silhouetted in order to make the shape of the sign matter more than the details in the interior. In Nelson Steven's 1973 mural "Work to Unify African People," the map of Africa is the abstract sign that is the center of the mural. ${ }^{10}$ The northeast part of this map is a black silhouette, and the rest of the map is red. Like Lama, Stevens was an AfriCobra member. His de- 


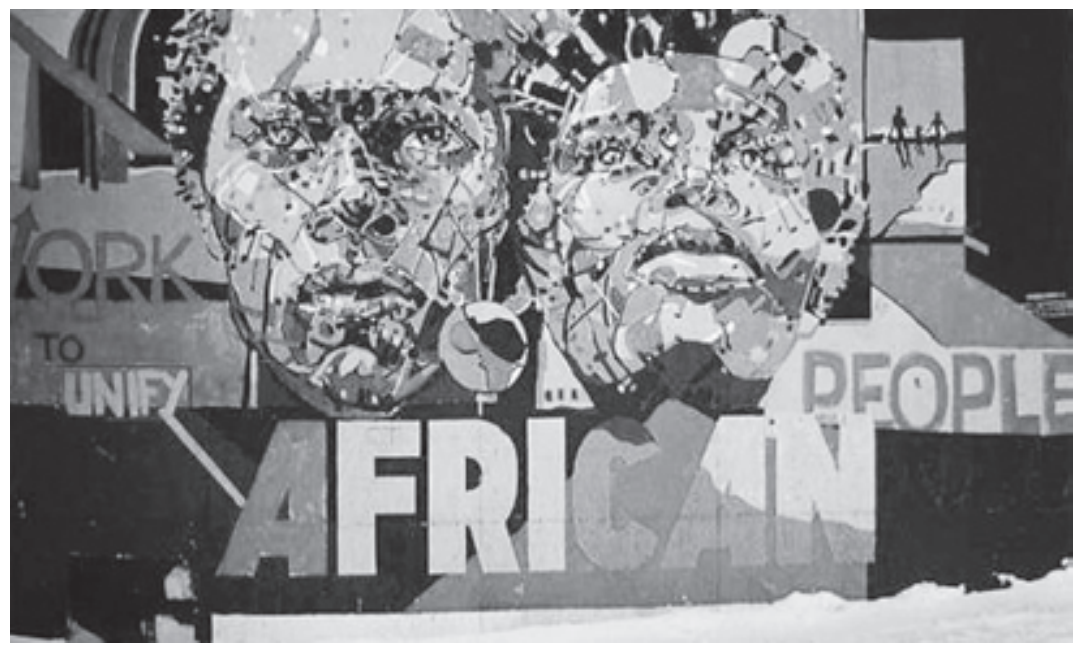

Fig. 1. "Work to Unify African People." Nelson Stevens.

piction of "mimesis at mid-point" is a stunning coloring of the black and white "stained glass" in Lama's drawing. Lama shows the woman's profile that is a realistic sign tilted as if it is in the process of entering the outer space of the abstract (that which the AfriCobra manifestos describe as "superreal").

Stevens shows what might appear when the profile turns into the full facial view. The two faces painted by Stevens are realistic and abstract. The clear facial features are the signs of realism but the explosion of colors (red, light blue, yellow, green) are signs of the abstract. The color black is most prominent around the hair line and the eyes. The mural captures the tension between black as a sign of race and black as an abstract sign (the "koolaid colors" embraced by the AfriCobra collective). The faces in the mural depict the mimesis at mid-point. The circle with the map of Africa is painted in between the faces. The aspects of realism in the faces are not only under siege by the nonblack "koolaid" colors"; the realism is also under siege by the partial silhouette of the map of Africa. This circle makes viewers focus on the abstract shape of the map of Africa as they contemplate the message in the painted words "Work to Unify African People." Abstract shapes become powerful signs when they deliver a message without the need for words. Nelson Stevens's in- 
clusion of the words follows the AfriCobra rule of "lettering" (the collective's decision to make the message explicit through words) but Stevens's multicolor painting of some of the letters underscores that the letters, like the image of Africa, are shapes. ${ }^{11}$ The movement pivoted on an investment in words as images; the new literacy was a performance of word pictures. The movement needed word pictures because words that were not treated as images would have been too private. The public language that the movement demanded was an insular blackness made public. The word pictures were tied to AfriCobra's "mimesis at mid-point" in the sense that they were public like graffiti (literally in the painting of the outdoor murals) and private like coded hieroglyphics. The flow, layering, and rupture that Tricia Rose ties to the graffiti of Hip Hop also explain the graffiti of this earlier movement-the Black Arts outdoor murals and the symbolic writing on the "walls and in the streets" of the entire cultural movement. ${ }^{12}$ The Black Arts writing "on the walls and in the streets" was the flow, layering, and rupture of visual and poetic lines.

Ted Joans's poetry volume Afrodisia (1970) highlights the Black Arts word pictures' conversation with the larger 196os conceptual art movement. This poetry volume intersects in complicated ways with the word and sign (and word as sign) layer of the 1960s conceptual art movement as well as the experimental typography layer of conceptual art. Joans mixes the pages with poems with pages of collages of cutout photography and other images (what he called "outagraphy"). Some of the cutout parts of photographs are used as silhouettes. The cover image is a collage that includes a cutout silhouette image of a phallus. The boldface black letters also have this cutout silhouette effect. Joans's word and image collages and the collages without words (placed on a separate page after particular poems) are conceptual art, in the sense that Joans makes readers/viewers think about the process of cutting and creating the collage of word and image as opposed to encountering the poems or collages as fully formed or complete. Joans's term outagraph signals that his poems and collages are an acting out, a type of conceptual art poetry.

This peculiar form of conceptual poetry is even more dramatic in the "neglphics" section of Larry Neal's Black Boogaloo. In "Neglphics: Or Graffetti Made Respectable," Neal lists propositions (such as "Bird Lives!!!" and "Black Power / Every Hour") that could be spray painted as graffiti. The propositions are separated by short lines, formed by asterisks (******************) ). ${ }^{13}$ After two pages with these graffiti tags, Neal then, in the next three pages, creates conceptual poetry that gives 
instructions for black poets, black painters, black musicians. These conceptual poems have the shape of prose poems-in-progress. The conscious engagement with conceptual art is most apparent when Neal includes a marginal note, after the "Notes for Black Painters," that is entitled "Idea for a Mural" (43). This same focus on the idea for a work, and not the completion of a work, shapes Larry Neal's manifesto "Some Reflections on the Black Aesthetic." In the first edition of The Black Aesthetic (1971), which includes this manifesto, the following words preface the beginning of this most visual verbal manifesto: "This outline below is a rough overview of some categories and elements that constituted a 'Black Aesthetic' outlook. All of these categories need further elaboration, so I am working on a larger essay that will tie them all together." ${ }^{14}$ This manifesto is printed in such a manner that readers must rotate the book and read this work in process horizontally, with a counterliteracy gaze that literally changes the normal orientation of the textual object. When we consider "Some Reflections" as conceptual art, the "idea," the black aesthetic, emerges as pure assemblage. Neal shows that one vital layer of the movement was the commitment to not textualizing the ephemeral.

In Taking It to the Streets: The Social Protest Theater of Luis Valdez and Amiri Baraka (1997), Harry Elam recognizes that urgency "by definition is ephemeral." ${ }^{15}$ Elam's insight is as crucial as Kimberly Benston's claim that the Black Arts Movement staged the "essential gesture of authentic blackness" (italics mine). ${ }^{16}$ We may initially think the oppositethat the urgency of a movement that was performing black nationalism, collective black consciousness, and Black Power would demand that which is profoundly solid, not that which is ephemeral. When we connect the movement's critique of the text as an object (and the critique of art itself as an object of cultural capital) to the movement's emphasis on institution-building, we gain a new way of understanding the urgency of process and the ephemeral as coterminous with the urgency of Haki Madhubuti's insistence that black nationalism "means publishing our own books." 17 In order for the "Black Book" to not become an object, it needed to somehow remain open; it had to make readers feel that it was not a monument but a happening, an event. Indeed, in the opening essay in the anthology Black Fire (1968), James Stewart framed this pivotal Black Arts text as "fragile" and "not fixed." He wrote, "The work is fragile, destructible; in other words, there is a total disregard for the perpetuation of the product, the picture, the statue, and the temple." ${ }^{18}$ In order to understand why and how this movement made the evanescent matter, 
we must remember the explicit theorizing about process as the highest aesthetic value. In the opening essay of Black Fire, Stewart warns readers to not transform this grassroots process of consciousness-raising into a frozen object of study. Stewart asserted, "Art goes. Art is not fixed. Art can not be fixed. Art is change, like music, poetry and writing are, when conceived" (4-5).

The movement's critique of the treatment of text as object was deeply connected to the movement's critique of the white power structure. In the play Malcolm: '71, or Publishing Blackness: Based Upon a Real Experience (1971), Ed Bullins critiques the academy's production of books that collect and frame the movement in a manner that crushes the spirit of black self-determination at the core of the movement. This play dramatizes the problem of who frames whom and who collects whom. In this short play, "WHITEGIRL" calls "BLACKMAN" in order to ask him to "collect a section" in an anthology she is editing. ${ }^{19}$ The play ends when "BLACKMAN" ends this conversation once he hears the woman address her dog named "Malcolm." The final lines read:

BLACKMAN: Hey ... could I ask you a question?

WHITEGIRL, beaming: Oh ... why surely.

BLACKMAN: Is your dog named "Malcolm"?

WHITEGIRL: Yes.

BLACKMAN: Who is it named after?

(Pause. Dog barks.)

whITEGIRL, hesitant: After Malcolm X.

(The BLACKMAN gently hangs the phone up.)

Lights down.

Blackness. (136)

Bullins connects the taming of Black Power to the white collection of the black sources. The play shows that an archive controlled by the dominant (white) power structure aimed to absorb the movement and the repertoire of black self-determination. Bullins recognized that short plays could stage the revolution in a manner similar to performance poetry. In his manifesto "A Short Statement on Street Theater" (1968), he explained, "Short, sharp, incisive plays are best ... Each individual in the crowd should have his sense of reality confronted, his consciousness assaulted" (288). Just as Diana Taylor counsels, "The live can never be contained in the archive," Bullins warns, in Malcolm: '71, that the textual production 
of blackness cannot remain on the "leash" of those who produce books that intentionally or unintentionally claim ownership of experiences they have not lived. ${ }^{20}$ Another Black Arts writer, Kalamu ya Salaam, uses the image of the leash as he thinks about what is at stake in black textual production. As he describes the role of white patronage during the Harlem Renaissance, he argues that Harlem Renaissance writers "were always on the leash of white patrons and publishing houses."21 Salaam, Bullins, and the other aestheticians of Black Power were hyperconscious of the fact that the textualization of subaltern knowledge (each textual production that claims knowledge of the subaltern) can reinforce a dominant culture industry that often becomes White Power.

Fight the Power! From the Harlem Renaissance to the Art of Black Power

The danger tied to the textualization of movement, gesture, sound, and performance is dramatized during the Black Arts Movement. As writers in the Black Arts Movement fought against the textual taming of radical black processes and actions, they produced texts that performed the packaging of the unpackageable. Many of the differences between the Harlem Renaissance and the Black Arts Movement are tied to the different collection practices during these movements. The Black Arts Movement staged the black collection of blackness.

In Signs and Cities: Black Literary Postmodernism (2003), Madhu Dubey argues that the 1970 s is the beginning of African American literary postmodernism. She bases this argument partly on the fact that by the 1970s the majority of African Americans, whether Southern or Northern, are urban. She sets up black postmodernism as an urbanity that is, in many cases, set apart from the "face to face" imagined communion in the rural South. She also defines black literary postmodernism as embodying a skeptical stance toward print literacy. The beginning of the Black Arts anthology Black Fire dramatizes this skepticism about the book. The opening note reads:

It is obvious that work by: Don Lee, Ron Milner, Alicia Johnson, Carl Boisssiere, Katibu (Larry Miller), Halisi, Quincy Troupe, Carolyn Rodgers, Jayne Cortez, and Jewel Lattimore Shd be in this collection. Various accidents kept this work from appearing 
in 1st edition. We hoped it wd be in the paperback, but these devils claim it costs too much to reprint. Hopefully, the 2nd edition of the paperback will have all the people we cd think of. The frustration of working thru these bullshit white people shd be obvious. ${ }^{22}$

Dubey's theory of skepticism about print literacy gains new dimensions when we remember this opening note in Black Fire. This anthology blurs the boundaries between Dubey's theory of African American postmodernism and Houston Baker's theory of African American modernism as "deformation of mastery." The postmodern is then, as many have recognized, that continuation of the most radical aspects of modernism. The collaborations and conflicts that shaped both the Harlem Renaissance and the Black Arts Movement are finally a steady reckoning with one of the key tenets of literary modernism and postmodernism-the difference between process and object. The critical questions about blackness, during these movements, were questions about blackness as process and blackness as object.

Comparing anthologies shows that the Black Arts Movement staged blackness as both object and process, whereas the Harlem Renaissance lacked any real focus on what the Black Arts Movement imagined as an ideology that could be named "black." Indeed, in the latest edition of Black Fire, Baraka, in the new introduction, explains that BARTS (Black Arts Repertory Theater School) "self-destructed" because "Black' is not an ideology." ${ }^{23}$ During the Harlem Renaissance, there were clearly celebrations of racial and cultural pride, but this cultural movement, unlike the Black Arts Movement, did not boldly and consistently attack whiteness as a dominant cultural aesthetic. The Black Arts Movement fought against a white dominant culture industry that constantly transformed grassroots culture into the capital of dominant culture institutions. James Stewart, in the first essay in Black Fire, argues that white art depends on matrixed art that requires an object, as opposed to nonmatrixed black art. In the very first pages of Black Fire, there is great emphasis on the different aesthetic criteria that shape Western, white art and black art. Stewart asserts that white aesthetics depends on the precious, enclosed art object in contrast to the openness of black art. This essay, entitled "The Development of the Black Revolutionary Artist," is a call for black art that resists the enclosed nature of the "white models" and the transformation of culture into capital. In the opening essay of the Harlem Renaissance anthology The New Negro, Alain Locke presents art as the gift 
that the Negro offers, the gift that proves that Negroes should be treated as worthy, fellow citizens. These two movements, in these anthologies, were literally packaged as having very different understandings of the relation between African American art and dominant culture capital.

Grassroots collaboration can differ greatly from the modes of production of the dominant culture industry. The collaboration embodied in the anthology Black Fire was grassroots. The poetry in the anthology was performed in outdoor and indoor community centers and rallies. Its oral and performative nature enabled this poetry to circulate widely among people who were not usually reading poetry or buying poetry books. The slim broadside poetry volumes were sold at public gatherings and community poetry readings. Standard single-page poetry broadsides enabled this grassroots poetry to become entirely portable, as captured in the following words in a poetic tribute to Gwendolyn Brooks, written by Haki Madhubuti: "pee wee used to carry one of her poems around in his back pocket" (Don't Cry, Scream, 1969). Protest and cultural movements such as the Black Arts Movement rely on an everyday type of collaboration between community leaders, writers, organizers, visual artists, event participants, and audience members. This organic collaboration is fully the zone of process as opposed to the textual collaboration archived in anthologies (in books that are inevitably an object). To what extent are literary and cultural movements inevitably reconstructed and remembered as textual collaborations, as opposed to process-oriented, antiobject collaborations? Through the texts, how do we recover the seams, the processes of collaboration and conflict?

The New Negro bursts apart at the seams when one attempts to reconcile the editor's celebration of transformation and racial uplift and many of the younger poets' depiction of an everyday living that is, as Langston Hughes writes, "beautiful and ugly too." The New Negro was Locke's first book. He had published essays, but the editing of the anthology was his newfound currency. As he gathered the voices of the younger poets, he gave names and definitions to a movement in the process of unfolding. He announced, "In the very process of being transplanted, the Negro is becoming transformed." ${ }^{44}$ His anthology was also a site of transformation. The anthology gave national, transnational, and interracial visibility to the poets and sought to transform their individual poetics into the poetics of the New Negro aesthetic. The young poets, in The New Negro, sometimes use black in their poems, instead of negro. The words the new negro carried very different connotations from the everyday feel- 
ing tied to the word black in the 1920s, pre-Black Power period. In the poem "Dream Variation," written by Langston Hughes, the word Black is used in the following manner: "Dance! Whirl! Whirl! / Till the quick day is done. / Rest at pale evening, / A tall, slim tree, / Night coming tenderly / Black like me." Whereas Locke, in his editorial framing, makes the term New Negro signify a cultural awakening and the shared consciousness of those who are participating in this cultural renaissance, Hughes makes the word Black a bodily state of rest after the whirlwind of identity maneuvers. Locke's introduction attributes considerable motion to the "New Negro"; Hughes's poem imagines "black" as a state of tender rest. In the very beginning of Locke's introduction, the "old Negro" is figured as the troubling state of fixity. Hughes's use of "black" as tender rest, following a dance whirlwind, mediates between Locke's "New Negro" commotion and his "Old Negro" lack of motion. This mediating term signals that African Americans can travel and dwell, that the standing still need not be shameful, that a most local and grounded type of being need not be shameful nativism. In Locke's editorial frame, he celebrates the internationalism tied to the "Negro world in Harlem." He writes, "The pulse of the Negro world has begun to beat in Harlem" (633). This transnational pulse is quite different from the individual pulse of the resting black body that Hughes presents in the poem "Dream Variation."

Does the book (the textualization of this "pulse") crush the "beat" of it? As Locke curated the exhibition of "The New Negro" writers, he used one particular caption that reveals how the object status of the book can objectify the subjects described in the book. This telling "caption" appears in the essay "Youth Speaks." Locke writes, "Our poets have now stopped speaking for the Negro-they speak as Negroes. Where formerly they spoke to others and tried to interpret, they now speak to their own and try to express. They have stopped posing, being nearer to the attainment of poise" (659). It matters that Locke describes the young poets' seeming refusal of the external audience even as he (in the book he edits) presents the poets to the external audience. As Locke plays the role of the interpreter, he reveals, in this passage, that some of the young artists are aiming to stop the interpretation, the translation for "others." The subtitle of the first edition of The New Negro was indeed "An Interpretation." The posing that occurs in the editorial framing (to twist Frantz Fanon's words, the "Look, a New Negro" moments in Locke's editorial frame) is very different from the "attainment of poise" he sees in the anthologized literature. 
In the one published issue of Fire!! there is a move against this exhibition. The younger artists collaborate in the creation of Fire!! The title itself anticipates the Black Arts title, Black Fire. Instead of the opening essay, in The New Negro, Fire!! begins with a poem written by Langston Hughes. In this poem, fire is an image of becoming. The language of becoming and process is remarkably different from the object of study in Locke's framing of The New Negro. The riotous tone of this poetic epigraph fully anticipates the poetics of the Black Power movement. This magazine, with a red and black cover, aimed to burn the packaging of the New Negro. Hughes ends this poem with the vernacular words "Fy-ah, / Fy-ah, Lawd, / Fy-ah gonna burn ma soul." Whereas Locke argues, in The New Negro, that the final value of folk forms derives from their ability to be transformed into high art, Hughes makes the folk vernacular into the end product (the final product) of the process of becoming represented by the metaphor of fire. The entire poem, before the final vernacular black dialect, pivots on the present participle: "flaming, searing, penetrating, warning, revitalizing, melting, poking, weaving, satisfying, blazing." The present participle, in this poem named "Foreword," frames the final black dialect words and the entire magazine as a meditation on a black folk form that can exist on its own terms, not as raw material for a different register of New Negro folk art that would separate low brow and high brow, or, in Locke's terms, old Negro and New Negro. The most compelling image in this poem is of the "livid tongues [poking] between stone apertures." After an image of "steel and iron" bars of a gate, Hughes presents this image of the bruised tongue penetrating the small opening of a keyhole or decorative artwork on the gate. The gatekeepers of the New Negro movement are critiqued as Hughes's opening words frame Fire!! as a crude alternative to the polish of The New Negro anthology. The note of the crude is rendered directly in Hughes's reference to "beauty unadorned."

After this poetic Foreword, "Cordelia the Crude" is the first text included in this anthology. Wallace Thurman, in this short story, not only foregrounds the same grittiness as the poetic foreword (the grit created when the stone gates and walls are destroyed), but also a certain resistance to the transformation of culture into capital. Cordelia, the protagonist in this short story, is a sixteen-year-old "potential prostitute." This potentiality, not inevitability, is set up through Wallace Thurman's focus on Cordelia's assumption of the prostitute role when she happens to walk into the theater "simultaneously" with the narrator. She begins, as 
they sit in this movie theater, to perform the role (through her words) of an experienced prostitute, but the narrator does not play the role of the typical male client. He "had not even felt her legs" (6). When they leave the theater, he walks her home, they kiss, and he then gives her "two crumpled one dollars bills." At the end of the short story, we learn that he had given Cordelia her "firs' two bucks." His assumption that she is a prostitute, that their intimacy cannot be separated from the power relation of the money exchange, spurs Cordelia to begin living the life of a prostitute. It matters that this depiction of prostitution is included as one of the opening frames in Fire!! The note of prostitution resounds as writers in the Black Arts Movement accuse the Harlem Renaissance artists of pandering to white audiences and being controlled by white patronage. Fire!! did not last; this magazine only had one issue. As Thurman anthologized the more "crude" aspects of sexual politics, neurotic obsessions with lighter-skinned blackness, queer desire, and black love of the black primitive, he worked within the master's house with the great desire to destroy the master's house and create a less packaged space of black art. On the page that thanks the patrons of Fire!! there is a list of patrons, ending with Carl Van Vechten. At the end of the page, the "Board of Editors" write, "For the second issue of Fire we would appreciate having fifty people subscribe ten dollars each, and fifty more to subscribe five dollars each." Since the journal never had a second issue, the questions about culture and capital embedded in the art in Fire!! are as noteworthy as the literal lack of enough capital to sustain the journal.

After the list of patrons and the call for subscribers to the second issue, the following words appear: "We make no eloquent or rhetorical plea. Fire speaks for itself." These words suggest a refusal to perform, a refusal to make a dramatic appeal. These words also signal that the board of editors (Thurman, Hughes, Gwendolyn Bennett, Richard Bruce, Zora Neale Hurston, Aaron Douglas, and John Davis), as they collaborate in this production, decide to not give Fire!! any rigid frame. It is much more open than The New Negro. The title "Fire" is not a racial designation; it unnames. Through the lens of one of the poems in Fire, Edward Silvera's "Jungle Taste," this unnaming in the title "Fire" can be connected to the power of naming embedded in the word black. Silvera, in "Jungle Taste," uses the word black as he depicts the songs of men and faces of women. Within this troubling gender divide between male sound and female embodiment (awfully similar to Jean Toomer's "She does not sing; her body is a song"), Silvera repeatedly uses the word black as he refers 
to the identity of the men singing and women being viewed. The racial identity of the speaker in the poem is not given in the first stanza. He is initially the unnamed speaker who can unname the songs as he rewrites the "weird strangeness" that outsiders hear as "not strange to me." In the second stanza, the speaker moves from the power of the unnaming to the power of renaming. He (the speaker) is identified as "Black" when "Black" emerges as the name given to subjects who can see what outsiders cannot see: "Dark hidden beauty / In the faces of black women / Which only black men / See." This shift from the unnaming (the first step when the old name must be canceled out, the impulse to add not to the standard word) to the renaming (the next step of a self-determination set apart from the outside gaze) fully anticipates the poetics of the 1960 and early 1970 B Black Arts Movement.

When some of the young poets in the Harlem Renaissance used the word black, not Negro, they were being transgressive since they knew that the bourgeois, racial-uplift types did not approve of the term. In the 1920s, in the United States, the term black was very multivalent. For some African Americans in the 1920s, the term black simply meant dark skin. Overall, African Americans in the 1920 did not use the term as a reference to the race. In "What Are We?", an article published in 1926 in The Messenger, George Grant argues that the term Black American satisfies "a long felt want." As he explains the difference between the name Black American and the name Negro, he writes, "The argument for it begins with the fundamental assertion that we are not Negroes (niggers) or colored people (cullud fellahs) but Americans; if it is necessary to distinguish us from the white Americans, then we are BLACK AMERICANS; not all of us are black, not all of white people are white, but 'black' and 'white' are used here to classify rather than to describe." ${ }^{25}$ This rationale, during the Harlem Renaissance, for using black was different from the argument used in the Black Arts Movement. Grant insists that black may only be necessary as an addition to American; the term American is the base term, in his view, and black signifies a secondary racial classification. During the Harlem Renaissance, the term Negro was often equivalent to the term Black in the Black Arts Movement. Negro as opposed to colored was a source of pride. The term black, when used in the poem "Jungle Taste" in Fire!!, signals a kind of cultural and racial pride that has a different valence from the pride tied to the word Negro. The very title of Silvera's poem - "Jungle Taste"-emphasizes that the blackness depicted is not tied to the racial uplift of the New Negro discourse. Silvera names 
the beauty that only "black men" can see; his use of the term black is anchored in the difference between the gaze of those in the "jungle" (a term he is clearly reclaiming) versus the outsiders' ways of seeing. During the Black Arts Movement, the word Black (in a capitalized form, not the lowercase version in Silvera's poem and many other Harlem Renaissance poems) is staged as a name that explicitly rewrites the sensibility tied to the word Negro.

Black Fire begins with the call for nation building and ends with the inner space of consciousness. Black Arts poetics constantly crossed the boundary between black inner space and black public grassroots space. The anthologizing of the movement, in Black Fire, performs this movement through public and inner space. The editors, Larry Neal and Amiri Baraka, through their foreword and afterword (written by Neal), move from the call for black nation building and liberated minds to Neal's celebration of the space created by the destruction of double consciousness. Larry Neal uses the words "the destruction of double consciousness" as he explains, in the Afterword of Black Fire, that the young Black Arts writers are refusing to see themselves through the eyes of others. Du Bois's theory of double consciousness finally pivots on the binary between "self-consciousness" and "the eyes of others." As Neal channels and expands Du Bois's theory, he revels in the "peculiarly black sensation" of suddenly breaking out of the binaries by experiencing the entire world as "black." There is a fundamental difference, in this anthology, between the setting of boundaries between black and white and Neal's final move to the celebration of an aesthetic that makes blackness "contain multitudes." ${ }^{26}$ Like the journal Black World (edited by Hoyt Fuller), Black Fire was the textual production of a counterworldview, hence the focus on the precise meaning of the word cosmology, in the anthology's opening essay.

\section{Coda}

During the Black Arts Movement, "Black" is bound as the unbound. The Black Arts impulse to make art that defied the dominant norms was tied to the impulse to make art that was too excessive to be contained in books. The dreams of artists to find more room to breathe within oppressive structures made them yearn to break out of the rules that defined painting, murals, sculpture, poetry, drama, and prose. In each of the genres, the artists moved to what the AfriCobra collective named 
"mimesis at mid-point," the shift from the mimetic ("black is") to the abstract and the layered ("black might be...."). Mimesis at mid-point is also a way of thinking about the relation between the black mirrors (in this movement's love affair with blackness) and the state of suspension and pauses that occurred as people stopped and began to analyze the movement that was unfolding. The experimental art of the movement was bound by the ideological frames of the movement, but the experimental art also created the movement's contours and frames. African American cultural movements settle in books and keep moving. "Gon do that book [... ] Our Black Book" - those words from the visual artist to the writer (in Abernathy's letter to Baraka) were the words of a photographer who, like the other Black Arts photographers, was consciously attempting to document a movement as it unfolded. The photographers' impulse to create the visual archive as the movement was unfolding was the impulse to capture that which was beginning and that which was always already beginning to end. The flash of their cameras offers a vivid way of understanding the "black book" as imagined by the Black Arts Movement; the black book was the container of the evanescent, an archive of the ephemeral. Those telling last words of In Our Terribleness"Now get up and go"-signal the Black Arts Movement's refusal to allow the black book to be a still object of cultural capital that could be appropriated by an external, non-black dominant structure. The Black Arts Movement was a movement to build black cultural institutions, but this institution-building was not disconnected from a critique of texts as objects, commodities, or monuments.

Abernathy's epistolary appeal to Baraka "To Imamu DIG [ . . . ] NO MATTER WHAT / GON DO THAT BOOK [ . . . ] LATER FOR ANY SLOW MOTION / ideas / of any bodies" echoes the call for words that embody movement in the poem "Black Art"- "live words of the hip world live flesh \& coursing blood." The black book, in the Black Arts imagination, is a peculiar container, an open container of "live words." Interstices, an architecture journal, frames the call for papers for a special issue on "unsettled containers-aspects of interiority" with the question "When is a set of walls an interior, when is an object a container, and when is a container a world?" In a similar manner, Baraka insists, in "Black Art," that "We want a black poem. And a / Black World. / Let the world be a Black Poem." This probing of the difference between the object that is a container and the container that opens up to a "world" explains the Black Arts rage against reproducing books of highbrow capital and the Black Arts belief in books that would resist closure. Indeed, 
after the publication of In Our Terribleness, the book transformed into a travelling four week "photographic exhibition." In a 1971 issue of Black World, this post-book exhibit was advertised in the following manner.

\begin{abstract}
Jihad Productions sponsors 'A Photographic Exhibition/ In Our Terribleness,' featuring photos by Fundi from the book, In Our Terribleness, by Fundi and Imamu Amiri Baraka. The exhibit is made available to museums, universities, schools, churches, galleries and other institutions. The approximate shipping weight of the framed 43 photos in the exhibit is 500 pounds. Cost for a four week exhibition is $\$ 125.00$, plus shipping charges. ${ }^{27}$
\end{abstract}

The physical book was not supposed to contain the fire. The book was not a post-exhibit catalog; the traveling exhibit was the post-book event.

\title{
Notes
}

1. Houston A. Baker Jr., Modernism and the Harlem Renaissance (Chicago: University of Chicago Press, 1987). Baker uses the term deformation of mastery throughout this study of African American modernism.

2. Richard Wright, Black Power (New York: Harper \& Brothers, 1954). The complete dedication "To the Unknown African" is: "TO THE UNKNOWN AFRICAN who, because of his primal and poetic humanity, was regarded by white men as a 'thing' to be bought, sold, and used as an instrument of production; and who, alone in the forests of West Africa, created a vision of life so simple as to be terrifying, yet a vision that was irreducibly human ..." (n.p.).

3. I am clearly drawing upon Michael Warner's theory in Publics and Counterpublics (2005).

4. Imamu Amiri Baraka and Billy Abernathy, In Our Terribleness (Some Elements and Meaning in Black Style) (Indianapolis: Bobbs-Merrill, 1970). This text is unpaginated.

5. Moorland Spingarn Research Center, Howard University, Amiri Baraka papers, Box 12.

6. Book cover quote, Middleton A. Harris, The Black Book (New York: Random House, 1974).

7. Ibid., preface, n.p.

8. In Our Terribleness, n.p.

9. In the catalog for the 1973 AfriCobra III exhibit at University of Massachusetts Amherst, the "aesthetic principle" of "mimesis at mid-point" is described in the following manner: "B. MIMESIS AT MID-POINT, design which marks the spot where the real and the unreal, the objective and the non-objective, the plus and the minus meet. A point exactly between absolute abstractions and absolute naturalism." 
10. This mural was created in 1973 at United Community Construction Workers Labor Temple, Roxbury, Boston, Massachusetts.

11. In the 1973 AfriCobra catalog, the principle of lettering is described in the following manner: "The subject matter must be completely understood by the viewer, therefore lettering would be used to extend and clarify the visual statement. The lettering was to be incorporated into the composition as a part of the visual statement and not as a headline."

12. Tricia Rose, Black Noise (Middletown: Wesleyan University Press, 1994).

13. Larry Neal, Black Boogaloo: Notes on Black Liberation (San Francisco: The Journal of Black Poetry Press, 1969), 40.

14. Larry Neal, "Some Reflections on the Black Aesthetic," in The Black Aesthetic, ed. Addison Gayle Jr. (Garden City, NY: Doubleday, 1971), 13.

15. Harry J. Elam Jr., Taking It to the Streets: The Social Protest Theater of Luis Valdez and Amiri Baraka (Ann Arbor: University of Michigan, 1997), 132.

16. Kimberly Benston, Performing Blackness: Enactments of African-American Modernism (New York: Routledge, 2000), 32.

17. Haki Madhubuti, GroundWork: New and Selected Poems of Don L. Lee/Haki R. Madhubuti (Chicago: Third World, 1996), 21.

18. LeRoi Jones and Larry Neal, Black Fire: An Anthology of Afro-American Writing (New York: William Morrow, 1968), 4.

19. WHITEGIRL says, "Hush, Malcolm! . . you wouldn't imagine how terribly, terribly radical and revolutionary this book is going to be! ... And I was hoping that, if you could collect a section for the Blacks ... I mean the Black poets, of course, ..." (136). Ed Bullins, Ed Bullins: Twelve Plays and Selected Writings, ed. Mike Sell (Ann Arbor: University of Michigan Press, 2006), 135-36.

20. Diana Taylor, The Archive and the Repertoire: Performing Cultural Memory in the Americas (Durham: Duke University Press, 2003), 173.

21. Kalamu ya Salaam, The Oxford Companion to African-American Literature (New York: Oxford University Press, 1997), 40.

22. Amiri Baraka and Larry Neal, Black Fire: An Anthology of Afro-American Writing (Baltimore: Black Classic Press, 2007), xvi.

23. Amiri Baraka and Larry Neal, Black Fire: An Anthology of Afro-American Writing (Baltimore: Black Classic Press, 2007), xviii. The full passage reads: "The Black Arts Repertory Theater School self- (and FBI) destructed because 'Black' is not an ideology and so the unity gained under that finally nationalist but reductionist label, though it was an attempt to locate \& raise the National Consciousness, could not hold. In that emotional spontaneity there was not an advanced enough unity to maintain the eclectic entity that 'Black' had brought together, Nationalists, Muslims, Yoruba devotees, Marxists, under the cover integrationists, Christians, all the above-ists."

24. Alain Locke, ed., The New Negro: Voices of the Harlem Renaissance (New York: Touchstone, 1997), 6.

25. George Hutchinson, The Harlem Renaissance in Black and White (Cambridge: Belknap Press, 1995): 298.

26. I am echoing Walt Whitman's famous words in "Song of Myself" - "Do I contradict myself? / Very well then I contradict myself, / (I am large, I contain multitudes.).”

27. Black World 21 (Dec. 1971): 50. 



\section{SELECT BIBLIOGRAPHY}

The following lists are designed to introduce specialists in African Americanist studies and textual scholarship to each other's fields, while also covering previous studies that have combined both disciplines.

\section{Overviews of Editorial Theory}

Bornstein, George, and Theresa Tinkle, eds. The Iconic Page in Manuscript, Print, and Digital Culture. Ann Arbor: University of Michigan Press, 1998.

Bornstein, George, and Ralph G. Williams, eds. Palimpsest: Editorial Theory in the Humanities. Ann Arbor: University of Michigan Press, 1993.

Bryant, John. The Fluid Text: A Theory of Revision and Editing for Book and Screen. Ann Arbor: University of Michigan Press, 2002.

Cohen, Philip, ed. Devils and Angels: Textual Editing and Literary Theory. Charlottesville: University of Virginia Press, 1991.

Eggert, Paul. Securing the Past: Conservation in Art, Architecture, and Literature. Cambridge: Cambridge University Press, 2009.

Genette, Gerard. Paratexts: Thresholds of Interpretation. Trans. Jane E. Lewin. Cambridge: Cambridge University Press, 1997.

Greetham, D. C., ed. The Margins of the Text. Ann Arbor: University of Michigan Press, 1997.

Greetham, D. C. Theories of the Text. Oxford: Oxford University Press, 1999.

Loizeaux, Elizabeth Bergmann, and Neil Fraistat, eds. Reimagining Textuality: Textual Studies in the Late Age of Print. Madison: University of Wisconsin Press, 2002.

McGann, Jerome J. A Critique of Modern Textual Criticism. Chicago: University of Chicago Press, 1983.

McGann, Jerome J. Black Riders: The Visible Language of Modernism. Princeton: Princeton University Press, 1993.

McGann, Jerome J. Radiant Textuality: Literature after the World Wide Web. New York: Palgrave, 2001.

McGann, Jerome J. The Textual Condition. Princeton: Princeton University Press, 1991.

McKenzie, D. F. Bibliography and the Sociology of Texts. 1985. Cambridge: Cambridge University Press, 1999. 
Parker, Hershel. Flawed Texts \& Verbal Icons: Literary Authority in American Fiction. Evanston: Northwestern University Press, 1984.

Pettit, Alexander, ed. Textual Studies and the Common Reader: Essays on Editing Novels and Novelists. Athens: University of Georgia Press, 2000.

Shillingsburg, Peter. From Gutenberg to Google: Electronic Representations of Literary Texts. Cambridge: Cambridge University Press, 2006.

Shillingsburg, Peter. Resisting Texts: Authority and Submission in Constructions of Meaning. Ann Arbor: University of Michigan Press, 1997.

Shillingsburg, Peter. Scholarly Editing in the Computer Age: Theory and Practice. 3rd ed. Ann Arbor: University of Michigan Press, 1996.

Tanselle, G. Thomas. Textual Criticism and Scholarly Editing. Charlottesville: University of Virginia Press, 1990.

Williams, William Proctor, and Craig S. Abbott. An Introduction to Bibliographical \& Textual Studies. 4th ed. New York: Modern Language Association, 2009.

\section{Overviews of African Americanist Theory}

Awkward, Michael. Negotiating Difference: Race, Gender, and the Politics of Positionality. Chicago: University of Chicago Press, 1995.

Bernasconi, Robert, and Tommy L. Lott, eds. The Idea of Race. Indianapolis: Hackett, 2000.

Edwards, Brent Hayes. The Practice of Diaspora: Literature, Translation, and the Rise of Black Internationalism. Cambridge: Harvard University Press, 2003.

Gates, Henry Louis, Jr. Figures in Black: Words, Signs, and the "Racial" Self. Oxford: Oxford University Press, 1997.

Gates, Henry Louis, Jr. The Signifying Monkey: A Theory of African-American Literary Criticism. Oxford: Oxford University Press, 1988.

Gikandi, Simon. "Race and the Idea of the Aesthetic." Michigan Quarterly Review 40 (2001): 318-50.

Gilroy, Paul. The Black Atlantic: Modernity and Double Consciousness. Cambridge: Harvard University Press, 1993.

Harris-Lopez, Trudier. South of Tradition: Essays on African American Literature. Athens: University of Georgia Press, 2002.

hooks, bell. Black Looks: Race and Representation. Boston: South End Press, 1992.

Jarrett, Gene, ed. African American Literature Beyond Race: An Alternative Reader. New York: New York University Press, 2006.

Kawash, Samira. Dislocating the Color Line: Identity, Hybridity, and Singularity in African-American Literature. Stanford: Stanford University Press, 1997.

Mills, Charles W. Blackness Visible: Essays on Philosophy and Race. Ithaca: Cornell University Press, 1998.

Mills, Charles W. The Racial Contract. Ithaca: Cornell University Press, 1997.

Morrison, Toni. Playing in the Dark: Whiteness and the Literary Imagination. New York: Vintage, 1993.

Moten, Fred. In the Break: The Aesthetics of the Black Radical Tradition. Minneapolis: University of Minnesota Press, 2003. 
Napier, Winston, ed. African American Literary Theory: A Reader. New York: New York University Press, 2000. In this volume see especially Hortense J. Spillers, "Mama's Baby, Papa's Maybe: An American Grammar Book"; Deborah E. McDowell, "Black Feminist Thinking: The 'Practice' of 'Theory"; and Harryette Mullen, "African Signs and Spirit Writing."

Warren, Kenneth W. What Was African American Literature? Cambridge: Harvard University Press, 2011.

\section{Combined Approaches}

Andrews, William L. “Editing 'Minority' Texts.” In The Margins of the Text, ed. D. C. Greetham. Ann Arbor: University of Michigan Press, 1997.

Bornstein, George. "Afro-Celtic Connections: Hybridity and the Material Text.” In $\mathrm{Ma}$ terial Modernism: The Politics of the Page. Cambridge: Cambridge University Press, 2001.

Bornstein, George. "Textual Scholarship and Diversity: Which Needs Affirmative Action More?” Textual Cultures 3, no. 1 (2008): 65-76.

Bornstein, George. "W.E.B. Du Bois and the Jews: Ethics, Editing, and The Souls of Black Folk." Textual Cultures 1, no. 1 (2006): 64-74.

Brody, Jennifer Devere. "The Blackness of Blackness . . Reading Invisible Man.” Theatre Journal 57 (2005): 679-98.

Carson, Clayborne. “Editing Martin Luther King, Jr.: Political and Scholarly Issues.” In Palimpsest: Editorial Theory in the Humanities, ed. George Bornstein and Ralph G. Williams. Ann Arbor: University of Michigan Press, 1993.

Gardner, Eric. "Remembered (Black) Readers: Subscribers to the Christian Recorder, 1864-1865." American Literary History 23, no. 2 (Summer 2011): 229-59.

Hutchinson, George. The Harlem Renaissance in Black and White. Cambridge: Belknap Press, 1995.

Jackson, Leon. "The Talking Book and the Talking Book Historian: African American Cultures of Print-The State of the Discipline." Book History 13 (2010): 251308.

Marx, Steven. "Beyond Hibernation: Ralph Ellison's 1982 Version of Invisible Man." Black American Literature Forum 23 (1989): 701-21.

McCoy, Beth. "Perpetua(l) Notion: Typography, Economy, and Losing Nella Larsen." In Illuminating Letters: Typography and Literary Interpretation, ed. Paul C. Gutjahr and Megan L. Benston. Amherst: University of Massachusetts Press, 2001.

McHenry, Elizabeth. Forgotten Readers: Recovering the Lost History of African American Literary Societies. Durham: Duke University Press, 2002.

Raynaud, Claudine. "Changing Texts: Censorship, 'Reality,' and Fiction in Native Son." In Richard Wright: New Readings in the 21st Century, ed. Alice Mikal Craven and William E. Dow. New York: Palgrave Macmillan, 2011.

Sullivan, James D. "Killing John Cabot and Publishing Black: Gwendolyn Brooks's Riot." African American Review 36 (2002): 557-69.

Vogel, Todd, ed. The Black Press: New Literary and Historical Essays. New Brunswick: Rutgers University Press, 2001. 
Ween, Lori. “This Is Your Book: Marketing America to Itself.” PMLA 118 (2003): 90102.

Wilson, Ivy G. "Periodicals, Print Culture and African American Poetry." In A Companion to African American Literature, ed. Gene Andrew Jarrett. London: Blackwell, 2010.

Young, John K. Black Writers, White Publishers: Marketplace Politics in 20th-Century African American Literature. Jackson: University Press of Mississippi, 2006. 


\section{CONTRIBUTORS}

George Bornstein is C. A. Patrides Professor of Literature, Emeritus, at the University of Michigan, Ann Arbor. He has written or edited twenty books on nineteenth- and twentieth-century literature, most recently The Colors of Zion: Blacks, Jews, and Irish, 1845-1945 (Harvard) and a facsimile edition of W. B. Yeats's The Winding Stair and Other Poems (Scribner). A former president of the Society for Textual Scholarship, he has received numerous fellowships and awards, including from the Guggenheim Foundation, National Endowment for the Humanities, and American Council of Learned Societies.

Margo Natalie Crawford is an Associate Professor of African American literature, performance, and visual culture in the Department of English at Cornell University. She is the author of Dilution Anxiety and the Black Phallus and the coeditor of New Thoughts on the Black Arts Movement. Her essays appear in a wide range of books and journals, including The Cambridge Companion to American Poetry Since 1945, Callaloo, American Literature, Black Renaissance Noire, Black Camera, and The Cambridge Companion to the Harlem Renaissance.

George Hutchinson is a Professor of English and the Newton C. Farr Professor of American Culture at Cornell University. He is the author of In Search of Nella Larsen: A Biography of the Color Line (Harvard University Press, 2006), which won the Christian Gauss Award of Phi Beta Kappa among other honors; The Harlem Renaissance in Black and White (Harvard University Press, 1995); and The Ecstatic Whitman: Literary Shamanism and the Crisis of the Union (Ohio State University Press, 1986). He has edited The Cambridge Companion to the Harlem Renaissance (Cam- 
bridge University Press, 2007) and American Cocktail: The Memoir of Anita Thompson Reynolds, forthcoming in 2013 from Harvard University Press. He has held fellowships from the Guggenheim Foundation (201112) and the National Endowment for the Humanities (1992-93).

Gene Andrew Jarrett is Professor and Chair of the English Department at Boston University. He is the author of two books, most recently Representing the Race: A New Political History of African American Literature (New York University Press, 2011). He is also the editor of several books of African American literature or literary criticism, the latest being $A$ Companion to African American Literature (Wiley-Blackwell, 2010). Jarrett's work has been supported by a 2010 fellowship from Harvard's Radcliffe Institute for Advanced Study, where he began writing his third book, about the life and literature of Paul Laurence Dunbar.

William J. Maxwell is Associate Professor of English and AfricanAmerican Studies at Washington University in St. Louis, where he teaches twentieth-century American and African-American literatures. He is the editor of Claude McKay's Complete Poems (2008) and the author of New Negro, Old Left: African-American Writing and Communism between the Wars (1999) and the forthcoming FB Eyes: How J. Edgar Hoover's Ghostreaders Framed African-American Literature. He serves on the editorial boards of American Literature and American Literary History.

Ifeoma Kiddoe Nwankwo is Associate Professor of English at Vanderbilt University. Her publications include Black Cosmopolitanism: Racial Consciousness and Transnational Identity in the Nineteenth Century Americas, "The Promises and Perils of African American Hemispherism: Latin America in Martin Delany's Blake and Gayl Jones' Mosquito" (American Literary History 18, no. 3 and Hemisphere and Nation, ed. Robert S. Levine and Caroline Levander), "Insider and Outsider, Black and American: Rethinking Zora Neale Hurston's Caribbean Ethnography” (Radical History Review 87, ed. Lisa Brock, Robin Kelly, and Karen Sotiropoulos), and "Langston Hughes and the Translation of Nicolas Guillén's Afro-Cuban Culture and Language" (Langston Hughes Review 16, nos.1 \& 2, ed. Lesley Feracho). Nwankwo is coeditor (with Mamadou Diouf) of Rhythms of the Afro-Atlantic World and editor of African Routes, Caribbean Roots, Latino Lives (Journal of Latin American and Caribbean Ethnic Studies special issue) and Critical Approaches to Louise Bennett 
(Journal of West Indian Literature special issue) in addition to being the Founding Director of Voices from Our America, an international Public Humanities initiative.

James W. Smethurst teaches Afro-American Studies at the University of Massachusetts, Amherst. He is the author of The New Red Negro: The Literary Left and African American Poetry, 1930-1946 (1999), The Black Arts Movement: Literary Nationalism in the 1960s and 1970 (2005), winner of the Organization of American Historians' James A. Rawley Prize, and The African American Roots of Modernism: From Reconstruction to the Harlem Renaissance (2011). He is also the coeditor of Left of the Color Line: Race, Radicalism and Twentieth-Century Literature of the United States (2003) and Radicalism in the South Since Reconstruction (2006). He is currently working on the forthcoming S.O.S.-Calling All Black People: A Black Arts Movement Reader with John Bracey and Sonia Sanchez.

Ivy G. Wilson is an Associate Professor of English and Director of the Program in American Studies at Northwestern University, where he teaches courses on the comparative literatures of the black diaspora, with a particular focus on African American cultural studies. In addition to recently publishing Specters of Democracy: Blackness and the Aesthetics of Politics in the Antebellum U.S., his work on African American print cultures includes publishing the collected works of Albery Allson Whitman and James Monroe Whitfield as well as a forthcoming special section of African American Review on archives.

John K. Young is a Professor in the Department of English at Marshall University, where he teaches twentieth- and twenty-first-century American and British literatures, focusing especially on African American fiction and modernism. He is the author of Black Writers, White Publishers: Marketplace Politics in Twentieth Century African American Literature (2006), as well as several articles on the interpretive consequences of textual production history. Current projects include Implied Texts: Narrative Versions and Material Textuality. Young is the executive director of the Society for Textual Scholarship. 



\section{INDEX}

Note: Page numbers in italic indicate illustrations.

A. and C. Boni (publishing house), 100, 101

Abernathy, Fundi, 15, 189, 190, 207

abolition, 20, 21, 24, 33

advertising and publicity, $7,22,56,77,79$, $87,101-2,208$. See also marketing aesthetics. See also mimesis at mid-point authorial authenticity and, 164 Black Arts, 177, 178, 180-87, 193, 19798

Black Power and, 199

classes, economic, and, $180-81$

colonialism and, 129

Hughes and Bontemps and, 117

Kant's, 76

Larsen and Fauset and, 53

Neal and, 206

New Negro Renaissance and, 109, 110, 160

paratexts and, $188-89$

politics and, 10, 161, 170

process and, 198

racialist, 80

thick racialist, 69

Tiger's Eye and, 112

typography and, 52

white, 200

Wright and, $71,77,81$

"Aframericans," 114, 115, 130

Africa, 42, 57, 60, 72, 73, 113, 114, 165, 188, 194, 195
"Afric-American Picture Gallery" (Wilson), 23-25, 26

Afric-American Quarterly Repository, 18,21

Africana: Encyclopedia of the African and African American Experience (Gates \& Appiah, eds.), 34

African/American Library, 57

African American Literature beyond Race: An Alternative Reader (Jarrett), 168-69, 172

African American studies, 11, 34, 160-61

African Blood Brotherhood, 151

African Civilization Society, 21-22

AfriCobra (African Commune of Bad

Relevant Artists), 191, 193, 195, 196.

See also mimesis at mid-point

Afro-American (journal), 54

Afro-American Newspapers Inc., 130

Afrodisia (Joans), 196

Alcott, Louisa May, 52

Alexander, Lillian, 53

Alfred A. Knopf, Inc., 6, 51-52, 54-57, 63, 94, 95, 104

Aliened American, The (newspaper), 20

Allen, Thomas, 105

Along this Way (J. W. Johnson \&

R. Johnson), 96

Alternative Reader of African American

Literature (Jarrett), 14

American Abolition Society, 21 
American Hunger (Wright), 67, 84, 8788. See also Black Boy (Wright)

American identity, 9, 77, 85, 95, 98, 205. See also nationalism

American Negro: His History and Literature, The (Katz, ed.), 27-28

American Women Writers Series, 52, 53,58

Amini, Johari, 184, 189

Anderson, Sherwood, 85, 95, 97

Andrews, William L., 3

Anglo-African Magazine, 12, 18-35

Anglo-Saxons, 13, 94, 113. See also entries beginning white...

anthologies, 7, 11, 12, 14-15, 32, 160-73, $175,177-78$. See also specific anthologies

Anthology of Verse by American Negroes, $A n$ (N. White and Jackson), 112, 130 anticommunism, 145, 148, 150, 151, 15354. See also communism

anti-Semitism, 84, 100, 179

antitextuality, 15, 192-93

Appiah, Anthony, 96. See also specific works

Appleton, 94

Ara Vos Prec (Eliot), 104

Armstrong, Louis, 105

Arno Press, 1, 27-28

art and illustrations, 15, 45, 46, 101, 182, 189, 191-92, 193. See also covers and design; individual artists

Ashbery, John, 183

assimilation, 50

Assis, Machado De, 114

Aswell, Edward C., 70-72, 78, 82-86, 87

Atlantic Monthly (magazine), 24, 26, 79 audiences (readers)

anthologies and, 112, 115

Black Arts and, 15, 177, 183, 186, 189, 201, 202, 204

"black books" and, 191-92

black insurrections and, 25

"black literature" and, 11

Connerly and, 164

creation of, 102, 103 demographics and, 23

double, 5,68

fluid texts and, 9

Hughes and, 54

magazines and, 20, 26

Passing and, 58

white, 5, 24, 40, 50, 58, 78

whiteness and, 172

Wright and, 69, 74, 76, 77-78, 79, 87

authorial intention and authenticity, 7-8, $10,11,67-68,89,164,170$

authoritative texts, 2

Autobiography (Franklin), 139

Autographs for Freedom (Griffiths, ed.), 25

avant-garde, the, 13, 94, 95, 100

Azoulay, Katya Gibel, 164

Baker, Houston A., Jr., 5, 12, 41, 200

Baldwin, James, 8o-81, 136, 168

"Ballad for Americans," 93

"Ballad of Birmingham" (Randall), 189

"Ballad of the Brown Girl" (Cullen), 46

"Ballad of the Harp-weaver" (Millay), 46

Banjo (McKay), 53

Baraka, Amiri. See also specific works anthology formats and, 182

Black Arts Movement and, 184, 185, 186,197

"black books" and, 189-90

FBI and, 136, 137

oral performances of, $177,183,186$

Barbados, 117, 128, 129

Barnes, Albert, 101

BARTS (Black Arts Repertory Theater

School), 200

BBC, 122, 127, 128

Beacon Press, 61

Beardsley, Aubrey, 45

Beaty, Jerome, 170

"Behind a Mask" (Alcott), 52

Belize, 130

Bell, Phillip A., 21

Beloved (Morrison), 6

Bennett, Gwendolyn, 136, 204

Benston, Kimberly, 197 
Beowulf, 3

Bernays, Edward, 101

Beverly, William, 140

Bibb, Henry, 20

Bibb, Mary E., 18

bibliographic codes, 94, 100-101

Big Sea, The (Hughes), 97-98

Billy Budd (An Inside Narrative) (Melville), 2

Bim (journal), 128, 129

Black Aesthetic, The (Neal), 57, 197

Black America (journal), 176

"Black art," 108-9

"Black Art" (Baraka), 179, 183, 186, 207

Black Arts Movement. See also individual authors; specific texts

"American" vs. "Negro" and, 9

"black literature" and, 12

blackness and, 12, 197

Black versus American identity and, 9

books and, 189

editing and, 175-87

FBI and, 136, 137

material forms and, 14-15

performance and, 15

Silvera and, 205

textualization and, 199-205

Black Arts Repertory Theater School

(BARTS), 200

Black Boogaloo (Neal), 196-97

Black Book, The (Harris, Smith, Levitt \& Furman, eds.), 192

black books, 189-91, 197, 207

Black Boy (Wright), 13, 67, 81-89. See also American Hunger (Wright)

Black Dialogue (journal), 176

black editors, 12, 13, 19-20, 20-35, 23, 28, 33, 34, 44. See also Anglo-African Magazine; individual black editors

Black Fire (Baraka \& Neal), 176, 182, 185, 197, 198, 199-200, 206

Black Hearts of Men, The (Stauffer), 33

Black Hope (Wright), 82

Black Man: His Antecedents, His Genius, and His Achievements, The (W. W. Brown), 27
Black Poets, The (Randall), 182

Black Power, 176, 178, 179, 193, 197, 198, 199

Black Power (Wright), 188-89

black publishers, 23, 197. See also individual publishers

"black representational space," 11, 13, 39, 41,53

Black Riders (McGann), 7

Black Theatre (journal), 176

Black Voices, 185

Blackwell Anthology of African American Literature (Jarrett), 14, 160-61

Black World (journal), 57, 183, 206

Blake, William, 3, 102-3, 116

Blake; or, the Huts of America (Delany), $25,26,29-31$

BLKARTSOUTH, 179

"Bloodchild" (Butler), 168

Bloomsbury modernists, 99

"Blueprint for Negro Writing" (Wright), $69,89,149$

Bobbs-Merrill, 190

Boissiere, Carl, 199-200

Bonfire (Fisher), 82

Boni and Liveright, 94, 99-102, 103, 104, 105

Bontemps, Arna, 12, 13-14, 63, 99, 10831. See also Poetry of the Negro, The (Hughes and Bontemps, eds.)

bookbinders, 21, 22

Booker, Cory, 169

Book of American Negro Poetry (J. W. Johnson), 99, 112, 113-14, 130, 151, 153

Book of American Negro Spirituals, The

(J. W. Johnson and R. Johnson), 96

Book-of-the-Month Club, 13, 67-89

Book Review Section (FBI), 151

Borzoi book imprint, 98

Boston (Massachusetts), 23, 94, 95

Bowen, Robert Adger, 149, 153

Bowers, Fredson, 8

Boyer, Peter J., 169

"Boyhood Etchings" (Roberts), 120

Brace, Donald, 98 
Bracey, John Jr., 14, 175, 184

Braithwaite, William Stanley, 44-45

Braxton, Joanne, 182

Breiner, Laurence, 129

Bridge, The (Crane), 99

Briffault, Robert, 188

Briggs, Cyril, 151

Brighter Coming Day, A (Foster, ed.), 32

British Guiana, 117, 128

British Honduras, 117, 130

Broadside Press, 176, 182, 183, 185, 189

Brody, Jennifer DeVere, 3

Brooks, Gwendolyn, 201

Brown, Charles Brockden, 3

Brown, John, 33

Brown, Lloyd, 136

Brown, Sterling A., 28, 99, 136, 178, 182

Brown, William Wells, 9, 21, 27, 30, 58

Bruce, Richard, 204

Bryan, Vincent, 105

Bryant, John, 9, 30, 68

Bulletin of Radical Activities (Hoover), 148

Bullins, Ed, 1, 137, 198-99

"Bully Bolsheviki, The" (possibly Hoover), 154

Bunbury, H.S., 128

Bushell, Sally, 9

Butler, Octavia, 168

Cahan, Abraham, 94

Call and Response: The Riverside Anthology of the African American Literary Tradition, 181

Calvin, Floyd, 101-2

Campbell, E. Simms, 182

Canby, Henry Seidel, 78-79

Cane (Toomer), 9, 43, 44, 103-4

canonization, 5, 11, 29

"Captains, The" (Roberts), 120

Carberry, H. D., 121-22, 125

Carby, Hazel, 32

Caribbean authors, 12, 15, 57, 108-31

Caribbean Voices (radio program), 122, 128

Caroling Dusk: An Anthology of Verse by Negro Poets (Cullen, ed.), 11, 42,

44-45, 111, 112

Carson, Clayborne, 3

Cary, Mary Ann (Shadd), 18, 31

Cast the First Stone (Himes), 168

Cather, Willa, 3

Catholicism, 103, 194

CBS radio, 93

CDs, $185-86$

CEAA, 2, 3

Celtic Twilight movement, 102

Cerf, Bennett, 100

Chace Act (1891), 102

"Characteristics of Negro Expression" (Hurston), 149

Chaucer, Geoffrey, 3

Chicago (Illinois), 56, 68, 81, 84, 87, 99, $110,149,177,178,189-90$

Chicago Daily Tribune (newspaper), 111-12

Chicago Defender (newspaper), 110

Chicago Race Riots, July 1919 (Sandburg), 99

Child, Lydia Maria, 24

Childress, Alice, 136

Chiles, Katy, 30

CIA, 148

cities, 190, 199

City University of New York, 32

Civic Club dinner, 101

civil rights, 11, 98

Civil Rights movement, 28, 31, 52

classes, economic

aesthetics and, 180

audiences and, 22

"Dinner Party" and, 127

"For a Lady I Know" and, 42

Gay Woman and, 75

Hall and, 124

Hoover and, 139

"I Shall Remember" and, 121-22

Native Son and, 72

Ormsby and, 123

Passing and, 47, 55, 58, 61

Clotel (Clotelle/Miralda) (W. W. Brown), $3,9,30-31$ 
Coates, Benjamin, 27

Cohan, George M., 105

Cold War, 136, 137, 184

Coleman, Ornette, 177

Collected Poems of Sterling A. Brown, The

(M. Harper, ed.), 182

Collected Poetry of Paul Laurence Dunbar, The (Braxton, ed.), 182

Collier Books, 1, 57

Collins, Carita Owens, 152

Collymore, Frank, 128, 129

colonialism, 129

Color (Cullen), 42-43, 44-45, 47

color blindness, 10, 52, 164

Colored American (newspaper), 21, 22, 23

Colored Poetic League of the World, 130

coloring books, 193

Colors of Zion, The: Blacks, Jews, and Irish from 1845-1945 (Bornstein), 93-94

Coltraine, John, 176-77

"Coltraine/poem, a/" (Sanchez), 176, 183

Colum, Mary and Padraic, 95

Columbus, Christopher, 124

Commentary, 28

commercial factors

aesthetics and, 181

Anglo-African Magazine and, 26-27

anthologies and, 162, 164, 168

Baker on, 5

Book-of-the-Month Club and, 68, 71$72,78,81-82$

CDs and, 186

costs, 22

digital editions and, 3

Fire!! and, 204

Morrison and, 6

Native Son and, 69

New Negro and, 101

Nigger Heaven and, 59

Oprah and, 4

Passing and, 56-57

price, 21

racial profiling and, 163-64, 166, 168

Reynolds and, 82-83

scholarship and, 2

J. M. Smith and, 33 communism, 70, 72, 81, 87, 93, 144. See also anticommunism

Complete Poems of Frances E. W. Harper (Graham, ed.), 31-32

conceptual art, 193, 196-97

Connerly, Ward, 163

contexts, 14, 179-82

"coon songs," 105

Copper Sun (Countee Cullen), 44-46

copyright protection, 102

"Cordelia the Crude" (Thurman), 203-4

Cornish, Samuel, 20, 21, 23, 24

Cortez, Jayne, 184, 185, 199-200

cosmology, 206

Cotter, Joseph Seamon, 113

countermodernism, 13

Country Place (Petry), 168

covers and design. See also art and il-

lustrations

bibliographic work and, 7

Black Arts and, 189, 194, 196

digital editions and, 186

Fire!! and, 203

Native Son and, 79

Passing and, 49, 50, 57, 58-59, 60-61, 62

Quicksand and, 50

Yeats and, 102

Craft, Ellen, 28

Crane, Hart, 99

Crawford, Margo Natalie, 1, 9, 14-15

creoles, 118, 122-30, 126, 127

Crisis, The (journal), 44, 178, 181

Critique of Modern Textual Criticism, A

(McGann), 7

Croce, Benedetto, 99

"Cross" (Hughes), 50

Cross Creek (Florida), 178

cross-cultural fertilization, 96. See also specific national influences

Crusader, 151, 152

Cruse, Harold, 136

Cuba, 29

"Cuban Glide, The" (Bryan \& Tilzer), 105

Cullen, Charles, 45, 46, 182 
Cullen, Countee, 11, 13, 39-47, 6o, 112, $113,120,182$

Culler, Jonathan, 186

Cuney, Waring, 178

Daily Review (Hayward), 110

Dark Shadows (Du Bois), 98-99

Davis, Arthur P., 28

Davis, Frank Marshall, 136

Davis, John, 204

Davis, Thadious, 61

Dawson, Michael C., 162-63

"Death Sows a Seed" (Oxley), 130

Delany, Martin R., 13, 18, 19, 25, 28-30

Delany, Samuel R., 168

democracy, 98, 103, 167, 169

Dent, Tom, 185

design and covers. See covers and design

"Development of the Black Revolutionary Artist, The" (Stewart), 200

Dickinson, Emily, 32

digital texts, 3, 15, 30

"Dilemma of the Negro Author, The" (J. W. Johnson), 4, 68

Dillinger, John, 154

"Dinner Party 1940" (Sherlock), 127

Discipline and Punish (Foucault), 142

Donnell, Alison, 129

Donner, Frank J., 143-44

"Don't Tread on Me" (Razaf), 154

Dostoevsky, Fyodor, 99

"double audience," 5, 68

double-consciousness theory, 206

Doubleday, 71, 111

Douglas, Aaron, 101, 204

Douglass, Frederick, 3, 19-20, 26, 29, 33. See also specific works

Douglass, Sarah M., 31

Douglass Papers, 34

Dracula (Broadway Show), 100

"Dream Variation" (Hughes), 202

Dreiser, Theodore, 85, 99

Dubey, Madhu, 199-200

Dubliners (Joyce), 95

Du Bois, W. E. B., 58, 69, 96, 98-99, 136, 151, 206
Du Bois, Yolande, 46

Dumas, Alexander, 21

Dumas, Henry, 192

Dunbar, Paul Laurence, 42, 113, 165-66, 168,182

Durand, Oswald, 114

Dust Tracks on a Road (Hurston), 8, 9-10

Early, Gerald, 41

Ebony Rhythms (Murphy), 112, 130

Economic Consequences of Peace

(Keynes), 99

economic factors. See classes, economic; commercial factors

editorial federalism, 14, 138, 139-40, 153-55

"Editorial Problem of Final Authorial Intention, The" (Tanselle), 8

Eggert, Paul, 6, 7, 9

Elam, Harry, 197

electronic editions, 3, 15, 30

Eliot, T. S., 95, 97, 99, 104-5

Ellis, Aimé J., 72

Ellison, Ralph, 105, 136

Elmer, Jonathan, 72

Emerson, Ralph Waldo, 95

Empire Poetry League (England), 128

Encyclopedia Africana (Africana: Encyclopedia of the African and African American Experience) (Gates \& Appiah, eds.), 34

English, Darby, 11, 39

English influences, 44-45, 123-25, 128. See also individual authors

ephemeral, the, 197-98

Epstein, William H., 139

essentialism, 168

European authors, 94, 95, 99, 131. See also individual authors

European immigrants, 95, 96, 103

European Library imprint, 98, 99

Evangelist (newspaper), 21

everyday life, 201

Exiles (Joyce), 96 
Eysteinsson, Astradur, 76

Ezra Pound: His Metric and Poetry

(Eliot), 104

Fadiman, Clifton, 84

Fanon, Frantz, 186, 202

Faulkner, William, 99, 100

Fauset, Jessie, 52-53, 54, 62, 99, 101, 102

FBI (Federal Bureau of Investigation), $14,136-55$

FBI Story, The (Whitehead), 145

feminism, 31, 32, 33, 34, 58, 145, 166. See also gender

Feminist Press, The, 32, 33

"Fifty Years 1863-1913" (J. W. Johnson), $115-16$

Fine Clothes to the Jew (Hughes), 54

Fire!!, 35, 203-4

Fire and the Flint, The (W. White), 97

Fisher, Dorothy Canfield, 67-68, 78, 80, $81,82,84-86,88$

Fisher, Pearl, 53-54

Fisher, Rudolph, 53-54

Flotsam: Poems 1942-1948 (Collymore), 129

"fluid text," 3, 9, 30-31, 68, 89

Fluid Text, The (Bryant), 8, 9

Focus (journal), 128, 129

FOIA (Freedom of Information Act), $136,137,138$

folk vernacular, 203

"for black people (and negroes too) ..." (Lee), 193-94

Forster, E. M., 99

Foster, Frances Smith, 32, 35

Foucault, Michel, 142

Four Negro Poets (Locke), 43-44

framing, historical, 179-82, 184-85

Frank, Waldo, 99, 103-4

Franklin, Benjamin, 139

Frederic, Harold, 3

Frederick Douglass' Paper (newspaper), 22, 23, 31

"Freedom" (Larsen), 168

Freedom of Information Act (FOIA), $136,137,138$
Freedom's Journal, 20, 23

"Freedom Suite (For Sunny Rollins and Franz Kline)" (Baraka), 183

Freedomways (journal), 176

French Guiana, 117

Freud, Sigmund, 101

"From the Dark Tower," 46

Fugitive Slave Act (1850), 9

Fuller, Hoyt, 57-58, 136, 206

Gabler, Hans Walter, 8

Gandhi, Mahatma, 95

Gandy, Helen, 141

gangsters, 154-55

Gardner, Eric, 34

Garnet, Henry Highland, 22, 29

Garrison, William Lloyd, 23, 24

Garvey, Marcus, 130, 151

Garveyites, 181

Gates, Henry Louis, Jr., 5, 11, 12, 31, 34, 161,192

Gayle, Addison, Jr., 12, 136, 138

gender, 204-5. See also feminism; women

Genette, Gerard, 2

geographical organization, 185

gesture, 193

Gikandi, Simon, 76

Gilman, Charlotte, 32

Ginsberg, Allen, 183

Giovanni, Nikki, 137, 182

Giovanni's Room (Baldwin), 168

Glebe, The (journal), 100

Godey's Lady's Book (magazine), 26

God's Trombones (J. W. Johnson \&

R. Johnson), 96

Gogol, 97

Gold, Mike, 99

Goldman, Emma, 145

Gorki, Maxim, 95

Gottlieb, Robert, 6

Gourmont, Remy de, 99

graffiti, 196

Graham, Maryemma, 31-32

Gramsci, Antonio, 186

Grant, George, 205 
Great Depression, 129

Greg, W. W., 8

Griffith, Julia, 25

Grimké, Angelina Weld, 116

Grimké, Archibald, 152

Grosset \& Dunlap, 78

Guest, Barbara, 183

Guggenheim fellowships, 80

Guillory, John, 167

Guinzburg, Harold, 96

Haitian authors, 18, 117

Halisi, 199-200

Hall, Agnes Maxwell, 124-25

Hamilton, Thomas, 12, 19-27

Hampton Institute Camera Club, 182

Hansberry, Lorraine, 136

Harcourt, Alfred, 95, 98

Harcourt, Brace, 95, 98, 100, 104

"Harlem" (Hughes), 179

Harlem Gallery (Tolson), 93

"Harlem: Mecca of the New Negro" (special issue), 101

Harlem (New Negro) Renaissance anthologies and, 178, 181

Black Arts Movement and, 137, 199205

black representational space and, 13

Cullen and, 41, 42

FBI and, 14, 151, 153

Hoover and, 138, 148-55

Jewish publishers and, 47, 59, 61

Malcolm X and, 178

Passing and, 47, 59, 61

Poetry of the Negro and, 109

Van Vechten and, 97

visual artists, 101

White Power and, 199

Harlem Shadows (McKay), 99

Harmonium (Stevens), 97

Harper, Frances E. W., 13, 19, 26, 31-33,

$61,62,116,168$

Harper \& Brothers, 13, 41, 67-89, 71, 77, 79,82

HarperCollins, 67

Harper's (Bazaar, Weekly, and Monthly)

(magazines), 24, 26, 41, 94-95, 165
"Harrigan" (Cohan), 105

Harris, Cheryl, 79

Harrison, Edna L., 130

Hauptmann, Gerhardt, 95

Hayford, Harrison, 2

Haynes, Samuel, 130

Hayward (California), 110

Hecht, Ben, 99

Hellman, Lillian, 97, 99

Hemingway, Ernest, 99

Henderson, Stephen E., 12

Henry, Edward, 146

Henry Holt \& Co., 98

Herald Tribune (newspaper), 56

"Heritage" (Countee Cullen), 42-44, 51, 60

Herne, James A., 165

"Heroic Slave, The" (Douglass), 25

Hershey (Pennsylvania), 110

Herskovits, Melville, 101

"Her Thirteen Black Soldiers" (Archibald Grimké), 152

"Hidden Name and Complex Fate" (Ellison), 105

Himes, Chester, 136, 168

Hodges, Willis A., 20

Hollar, Constance, 128, 129

Holly, James Theodore, 18, 25

Holmes, Oliver Wendell, 86-87

"Home" (Toni Morrison), 6

homophobia, 179

Hoover, J. Edgar, 136-55

Horne, Frank, 116

Horton, George Moses, 115

Houghton Mifflin, 94

Howard University, 11, 137

"How Bigger Was Born" (Wright), 76

Howells, William Dean, 2, 94, 165-66

"Howl" (Ginsberg), 183

Huebsch, B. W., 95-97

Hughes, Langston

aesthetics and, 117

"African American" and, 12

audiences and, 54

everyday life, on, 201

FBI and, 136

Fire!! and, 204 
"Harlem," 179

Knopf and, 51

misrepresentation of, 178

process and, 203

Van Vechten and, 54

white, as, 12

whiteness, on, 129-30

works

Big Sea, The, 97-98

"Cross," 50

"Dream Variation," 202

Fine Clothes to the Jew, 54

"Harlem," 179

Montage of a Dream Deferred, 179

"Negro Artist and the Racial Mountain, The," 149

Poetry of the Negro, The (with Bontemps, eds.), 13-14, 108-31

Weary Blues, The, 97

Hundred Miles and Running, A (Craft), 28

"Hunted" (Marson), 119

Hurston, Zora Neale, 4, 8, 9-10, 32, 33, $69,149,168,204$

Hutchinson, George, 168

hybridity theorists, 96

identity politics, 179

ideology, 162-63, 179-82, 184-85, 207. See also politics

"If We Must Die" (McKay), 122, 151-52, 154

images, 189, 191-93, 193-94, 207-8. See

also antitextuality; art and illustrations

Imagistes, Des, 100

Imes, Elmer S., 53, 57, 59

Informer, The (O'Flaherty), 97

In Our Terribleness (Baraka \& Aberna-

thy, eds.), 15, 189-91, 192-93, 207,

208

In Our Time (Hemingway), 99

Interne, The (Thurman), 168

Interstices (journal), 207

Investigation Activities of the Department of Justice (U.S. Senate), 149

Invisible Man (Ellison), 5
Iola Leroy (Harper), 31, 32, 61

Irish, African American, 93-106

Irish Fairy and Folk Tales (Yeats, ed.), 102

Irish influences, 128. See also individual authors

"I Shall Remember" (Carberry), 121-22

Jackson, Deborah, 22

Jackson, Leon, 6

Jackson, Walter Clinton, 112, 130

"Jamaica Market" (Hall), 124-25

Jamaican poets, 117, 118-30

Jamaica Poetry League, 128

JanMohamed, Abdul R., 74

Jarrett, Gene, 14, 47, 160-61, 168-69, 172

jazz, 105, 152, 176-77, 183, 186. See also specific artists and works

Jews, 4, 13, 93-106. See also individual authors and publishers

Jihad Productions, 176, 182, 183

Joans, Ted, 196

Johnson, Alicia, 199-200

Johnson, Barbara, 80

Johnson, Douglas, 136

Johnson, Georgia Douglas, 136

Johnson, James Weldon. See also "double audience"

Memorial Collection, 11-12

publishers and, 51

Radicalism and Sedition, on, 153

Van Vechten and, 54, 98

works

Along this Way, 96

Book of American Negro Poetry, 99, 112, 113-14, 130, 151, 153

Book of American Negro Spirituals, The, 96

"Dilemma of the Negro Author, The," 4, 68

"Fifty Years 1863-1913," 115-16

God's Trombones, 96

Second Book of Negro Spirituals, The, 96

Johnson, Rosamond, 96

Jordan, Norman, 181

Journal of Black Poetry, 176, 183 
Journal of Black Poetry Press, 176, 182 Journal of Negro Education, 111

Joyce, James, 8, 95, 96, 97

"Jungle Taste" (Silvera), 204-6, 205

Kallen, Horace, 103

Kant, Immanuel, 76

Kaplan, Carla, 49

Kaross, Sonia, 147

Katibu (Larry Miller), 199-200

Katz, William Loren, 27, 28

Kaufman, Bob, 136

Kelley, James, 45

Kellogg, Paul, 101

Kerlin, Robert, 112, 113

Keynes, John Maynard, 99

Killens, John O., 136, 185

King, Martin Luther, Jr., 3, 11

King, Woody, 184

King Bolo, 106

Kingsport Time (TN), 110-11

Kirkus Review, 111

Knopf, A. A. (publishing house), 6, 5152, 54-57, 63, 94, 95, 104

Knopf, Alfred A., 56, 97, 98

Knopf, Alfred A., Jr., 98

Knopf, Blanche, 55, 97

Ku Klux Klan, 103

Kyk Over Al (journal), 128

Lama, Omar, 194

Lanier, 113

Larsen, Nella, 13, 47-63, 97, 168

Larson, Charles R., 1

Last Poets, 185

Later Works (Wright) (Rampersad, ed.), 67

Latin America, 114, 130. See also individual authors

Lattimore, Jewel, 199-200

Lawrence, D. H., 95, 97

Leaves of Grass (Whitman), 30

Leavitt, James S., 19

Lebanon Daily News (Hershey), 110

Lee, Don (Haki Madhubuti), 137, 184, 189, 193-94, 197, 199-200, 201

Lee, Ulysses G., 28 lettering, 196

Levine, Robert S., 29

Lewis, David Levering, 149

Lewis, Sinclair, 85, 98, 99

Liberator, The (journal), 23, 31, 104, 176

libraries, public, 27

Library of America, 67

Library of Congress, 141-42, 147-48

Life (magazine), 87

"Lindy Lou" ("The Watermelon Vine") (Allen), 105

Lippincott, 9

"Litany of the Dark People, The" (Cullen), 46

literacy, 199-200

Little, Brown (publishing house), 94

"Little Black Boy, The" (Blake), 116

Little Leather Library (Boni), 99

Liveright (publishing house), 95

Liveright, Horace, 99-100, 103, 104

"Lizard" (Hall), 124, 125

Locke, Alain, 42-45, 100, 101, 136. See also specific works

Long Dream, The (Wright), 70

Longfellow, Henry Wadsworth, 95, 116

Lori-Parks, Suzan, 4

Lotus Press, 176

Louisiana freemen of color, 116, 117

Louisville Courier-Journal (newspaper), 144

Lovell, John, 111

Loving, Arthur, 149

Lucy, Beth, 78

Lugosi, Bela, 100

lullabies, 113

Lustra (Pound), 97, 104

MacDermot, Thomas (Tom Recam), 123-24, 128, 129

Machine Gun Kelly, 146

Macmillan, 102

Madhubuti, Haki (Don Lee), 137, 184, 189, 193-94, 197, 199-200, 201

Madison, Charles A., 95

Main Street (Lewis), 99

Majors and Minors (Dunbar), 165

Malcolm: '71, or Publishing Blackness: 
Based Upon a Real Experience (Bullins), 1, 198-99

Malcolm X, 178

Manley, Edna, 128

Mann, Heinrich, 99

Manzano, Juan Francisco, 114

Mapps, Grace, 31

maps, 141-42, 145

March Hare notebook (Eliot), 106

Margetson, George, 130

marginalization, 119, 167-68

Marinoff, Fania, 51

marketing, 5, 7, 55-62, 68-69, 78-83. See also advertising

"Maroon Girl, The" (Roberts), 121

Marshall, Paule, 12

Marson, Una, 118, 119, 122, 128

Martí, José, 121

Martin Delaney, Frederick Douglass, and the Politics of Representative Identity (Levine, ed.), 29

Martinique, 117

Martin R. Delany: A Documentary Reader (Levine, ed.), 29

Marvin X, 184

Marxists, 186

Masters, Edgar Lee, 85

Matthews, Victoria Earle, 169-70

Maxwell, William J., 14

McCoy, Beth, 50-51, 52

McDowell, Deborah E., 32, 58-6o, 61

McFarlane, J. D., 127-28, 129

McGann, Jerome, 7, 8-9

McGraw-Hill, 71

McHenry, Elizabeth, 19

McKay, Claude

"African American" and, 12

Banjo, 53

FBI and, 136

Harlem Shadows, 99

"If We Must Die," 122, 151-52, 154

Poetry of the Negro, in, 118, 120, 130

Service and, 154

Voices from Summerland, in, 128

"White House, The" ("White

Houses"), 42, 44, 122

McKay, Nellie Y., 161
McLean, Alabama Falkner, 100

Medea and Some Poems, The (Countee Cullen), 46

media, 140, 148

Melville, Herman, 2, 29-30

Mencken, H. L., 85

Men of Mark (Simmons), 28

menorahs, 96

Mercer, William T., 27

Merriman, Brian, 103

Messenger, The (journal), 144, 149, 151, $153,178,181,205$

Mexicans, 103

Midnight Court, The (Merriman), 103

Millay, Edna St. Vincent, 46

Miller, Floyd J., 29

Miller, Larry (Katibu), 199-200

Mills, Charles, W., 15-16, 76, 81

Milner, Ron, 199-200

mimesis at mid-point, 194, 195, 196, 207

minstrel songs, 105, 138, 165

Miralda (Clotel/Clotelle) (W. W. Brown), $3,9,30-31$

misogyny, 179

Mitchell, W. J. T., 193

Moby Dick (Melville), 30, 180-81

Modern American Poetry (Untermeyer), 99

modernism

African-American, 200

Anglo-American, 94

Bloomsbury modernists, 99

Boni and Liveright and, 99

Celtic Twilight movement and, 102

counter-, 13

editorial method and, 68

Eliot and, 106

Liveright and, 100

McGann and, 8

Native Son and, 76

paratexts and, 80

publishers and, 93-106

social types and, 144

Modern Library, The, 60, 78, 99, 100, 102

Monroe, Willima C., 18 
Montage of a Dream Deferred (Hughes), 179

Moorland, 11

Mor, Amus, 177, 181

Morely, Christopher, 95-96

Morrison, Toni, 6, 60, 168, 171-72, 192, 193

Morrison, William, 128

Mosquitoes (Faulkner), 99

Moten, Fred, 4

Mother Earth (magazine), 145

Motley, Archibald, 61

Motley, Willard, 136

Mrs. Dalloway (Woolf), 72

Mulvey, Christopher, 3

murals, 193, 194-96, 197, 206-7

Murphy, Beatrice, 112, 113, 130

Murray, Sunny, 186

music, 105, 152, 176-77, 183, 185, 186, 196. See also specific artists and works

My Bondage and My Freedom (Douglass), 33

"My Evangeline" (Sloan), 105

My Soul's High Song (Countee Cullen), 182

NAACP, 98

Narrative of the Life of Frederick Douglass

(Douglass), 33

National Anti-Slavery Standard (newspaper), 22

national identity and nationalism. See also American identity; transnational factors

African American poets and, 126

Caribbean and, 121, 126, 127-28, 129, 130

Colors of Zion and, 94

Huebsch and, 96

Hoover and, 140-41, 143

Irish, 94, 102

New Negro and, 201, 202

race and, 12

segregation and, 11

nationalism, black, 179, 197 nationalist theory, 186

Native Americans, 103

Native Son (Richard Wright), 13, 67-81, 88-89

naturalism, 109

"Nature" (Carberry), 125

Neal, Larry, 12, 136, 177, 186, 196-97. See also specific works

"negliphics," 196

Negritude, 109

"Negro Artist and the Racial Mountain, The" (Hughes), 149

Negro Caravan (Brown, et al. eds.), 28

Negro Digest (Black World) (journal), 176

Negro Poets and Their Poems (Kerlin), 112,113

Negro Renaissance, 14

Negro Voices (Murphy), 112, 113, 130

Negro World, The, 151, 153, 181

Nelson, Cary, 182

New Negro, The (New Negro: An Interpretation, The) (Locke, ed.), 43-44, 100-101, 151, 153, 200-202, 203

New Negroes. See Harlem (New Negro) Renaissance

New Orleans (Louisiana), 179

Newton, Jane, 88

New York Age, 153

New York Amsterdam News, 93

New York City (New York), 94, 95, 103, 129, 178. See also specific journals and newspapers

New York Herald Tribune, 112

New York Public Library, 11, 41

New York Times, 1, 27-28, 111, 149, 163, 164

New York World, 50

Nietzsche, Friedrich, 99

Nigger Heaven (Van Vechten), 50-56, 59,97

"Nightfall" (Marson), 119

Nims, John Frederick, 111-12

9/11, second, 143

Nixon, Robert, 88

Nkombo (journal), 179

Nkrumah, Kwame, 188 
NKVD, 142

North Star, The (newspaper), 19-20, 23

Norton Anthology of African American Literature, The, 34, 161-62, 181

"Notes of a Native Son" (Baldwin), 81

Obama, Barack, 136, 163, 169, 179

Oberlin College, 22

object and process, 200, 207-8

O'Faolain, Sean, 96-97

O'Flaherty, Liam, 97, 99

O'Hara, Frank, 183

Okker, Patricia, 29

“On a Monument to Marti” (Roberts), 121

O’Neill, Eugene, 99

"On Imagination" (Wheatley), 116

"On Liberty and Slavery" (Horton), 115

"On National Vanity" (McFarlane), 127-28

"On Seeing Two Brown Boys in a Catholic Church" (Horne), 116

On These I Stand (Countee Cullen), 42, 46-47

Oppenheimer, George, 96

Opportunity (journal), 41, 54, 178, 181

Oprah's Book Club, 4

oral expression, 5, 176, 183. See also performance ethos

Ormsby, (Barbara) Stephanie, 123, 128

Our America (Frank), 103

"Our Greatest Want" (Harper), 32

outagraph, 196

Oxford Collected Black Writing Series

(Gates, Jr., ed.), 11, 34

Oxford University Press, 31

Oxley, Lloyd G., 130

packaging. See covers and design

paganism, 41, 42

painters, 197. See also individual painters

Palmer, A. Mitchell, 142, 143, 145, 147, 148

Pan Afrikan Peoples Arkestra, 183

Paradise (Morrison), 172

paratexts, 2, 15, 52, 86, 188-89

Parker, Dorothy, 97, 99
Passing (Larsen), 13, 47-63, 97

"Patriotism: A Menace to Liberty"

(Goldman), 145

Patterson, Louise Thompson, 136

Pavannes and Divisions (Pound), 97

Pennington, J. W. C., 25

People's Press, 23

performance ethos, 3, 5, 15, 176-77, 183, 184, 185, 186, 190-91, 201. See also

oral expression

"perspective," 89

Petipas' restaurant, 95

Petry, Anne, 168

Pittsburgh Courier, The (newspaper), 101-2

Plácido, 114

Plum Bun (Fauset), 53, 54, 61

Poe, Edgar Allan, 26, 113

Poems (Eliot), 97, 104

Poems of William Blake (Yeats), 102-3

Poetry of the Negro, The (Hughes \& Bontemps, eds.), 13-14, 108-31

poets, African American, first published, 97

political poems, 119, 122

politics. See also ideology; propaganda; individual political figures

aesthetics and, 10

African American Literature beyond

Race and, 172

Anglo-African Magazine and, 24

anthologies and, 167

Delany and, 34

Haynes and, 130

identity, 179-80

1960 and, 186

Poetry of the Negro and, 127-28

race and, 163, 164

racial representation and, 171

typography and, 52

popular culture, 105-6

Portrait of the Artist as a Young Man

(Joyce), 95

Post, Louie, 154

postcolonialism, 186

postmodernism, $8,172,199-200$ 
postracial era, 161, 163, 169-73. See also individual figures

poststructuralism, 2

Pound, Ezra, 97, 99-100, 104, 105

Prehistoric Burials (Sassoon), 97

printers, 21, 22

process and object, 197-98, 200, 201, 203, 207-8

propaganda, 55, 97, 101, 112, 114, 146

"Prospectus of the Afric-American Quarterly" (Whitfield), 18

Prosser, Gabriel, 29

Provincial Freeman and Weekly Advertiser, 18,20

Prufrock and Other Observations (Eliot), 104

psychoanalytic theory, 186

publicity and advertising, 7, 22, 56, 77, 79, $87,101-2,208$

publishers, African American, 23, 197. See also individual publishers

Publisher's Weekly, 56, 101

Putnam, Herbert, 141, 142, 146

Quicksand (N. Larsen), 48-49, 50, 58, 59, 97

Quill, Saturday Evening (journal), 178

Quinn, John, 100

Rabinowitz, Rachel, 106

Race Literature, 169-70. See also racial profiling of books

"Race Matters" (conference), 171

racial profiling of books, $163-64$

racial representation, $160-73,172$

racism, 10, 40, 42, 69, 168, 172-73, 179.

See also color blindness; politics; white control/dominant culture

Radcliff, John, 128

Radical Division (FBI), 143, 144, 145, 147, 148

Radicalism and Sedition Among the Negroes as Reflected in Their Publications (Hoover), 148-53

Rampersad, Arnold, 67

Ram's Horn, The (newspaper), 20
Randall, Dudley, 136, 182, 189

Randolph, Philip, 151

Random House, 94, 100, 192

Rawlings, Marjorie, 178

Ray, Charles Bennett, 21

Razaf, Andy, 152, 154

readers. See audiences

realism, 109, 195

"Recitatif" (Morrison), 168, 172

Redcam, Tom (Thomas MacDermot), $123-24,128,129$

Redmond, Eugene, 181

Red Radical Movement, The (pamphlet), 148

Red Summer (summer of retribution), $142-43,149,153$

reductionism, 167-68

"Red Wheelbarrow, The" (W. C. Williams), 179

Reed, Ishmael, 182

Reiss, Winold, 101

Repression and Recovery (Nelson), 182

Republican party convention, 93

Resisting Texts (Shillingsburg), 9

Reynolds, Paul, 70-71, 82-84, 86

Richards, Edward, 130

Rights of All (newspaper), 20

riots, 97, 99, 142, 149-50

Rise of David Levinsky, The (Cahan), 94

Rising Son, The; or, The Antecedents and

Advancement of the Colored Race

(W. W. Brown), 21

Roberts, Walter Adolphe, 119-20, 128

Robeson, Paul, 93

Rodgers, Carolyn, 189, 199-200

Rodin, August, 95

Rogers, J. A., 136

Rollins, Sonny, 177

romanticism, 41, 44, 120, 126, 153

Roosevelt, Eleanor, 111

Rose, Tricia, 196

Rossetti, Dante Gabriel, 3

Rowley, Hazel, 70, 85

Rukeyser, Muriel, 97

Russia, Soviet, 142, 151

Russian authors, 97 
Russian People’s House (New York City), 146

Russian Revolution, 143, 145

Russwurm, John B., 20

Rustic, Jane, 26, 31

Rutgers University Press, 58

Sacred Wood, The (Eliot), 97, 104

Salaam, Kalamu ya, 184, 199

Sanchez, Sonia, 14, 176, 180, 181, 183, 184, 185. See also specific works

Sandburg, Carl, 99

"San Francisco" (Roberts), 120

"San Gloria” (Redcam), 123-24

Sassoon, Siegfried, 97

Saturday Evening Quill (journal), 178

Saturday Review, 95-96

Savage Holiday (Wright), 168

scholarship, 1-12, 15-16, 29, 33, 34-35, 50, 53. See also individual scholars

Schomburg edition of Watkins Harper's complete poetry, 32

Schomburg, Arthur, 11

Schomburg Library of NineteenthCentury Black Women Writers, 31-32

Schuyler, George, 136

Scott-Heron, Gil, 185

Scottish influences, 128, 130. See also individual authors

"Scottsboro, Too, Is Worth Its Song" (Countee Cullen), 46

Sealts, Merton M., Jr., 2

Seasoned Timber (Fisher), 84

Second Book of Negro Spirituals, The

(J. W. Johnson and R. Johnson), 96

Securing the Past (Eggert), 9

Security Leagues, 103

segregation, 39

self-determination, 54, 129, 179, 198, 205

Sell, Mike, 176

Sensational Designs (Tompkins), 180

Seraph on the Suwanee (Hurston), 168

Service, Robert, 154

sexuality

Black Boy and, 68, 82
Color and, 45

Midnight Court and, 103

Native Son and, 68, 69-81

Passing and, 58, 59, 62-63

Shadd, Mary Ann (Cary), 18, 20

Shakespeare, William, 99

"Shakespeare Rag, The," 105

Shange, Ntozake, 60-61

Shapiro, Karl, 93

Shaw, George Bernard, 99

Sherlock, P. M., 127

Shillingsburg, Peter, 9, 68

"Shooting of Dan McGrew, The" (Service), 154

Shore Acres (Herne), 165

"Short Statement on Street Theater, A" (Bullins), 198

Signifying Monkey, The (Gates, Jr.), 5

signs, abstract, 194-95

Signs and Cities: Black Literary Postmodernism (Dubey), 199-200

Silvera, Edward, 204-6

Simmons, William J., 28

Simon and Schuster, 94

Sinclair, Upton, 97

"Slave Auction, The" (Harper), 116

slavery and slaves. See also abolition

Anglo-African Magazine and, 24, 25

Dunbar and, 165

narratives by slaves, 4,164

periodicals and, 19-20

poems and, 115, 116

white editors's narratives and, 4, 80, 192

Wright and, 188

Sloan, Mae, 105

Smethurst, James W., 9, 14, 175

Smith, Gerrit, 27, 33

Smith, James McCune, 13, 19, 23, 26, 33-35

Smith, William Gardner, 136

"social text" editing, 94

Soldier's Pay (Faulkner), 99

Sonny's Time Now (album), 183

Soulbook (journal), 176

Southern Road (Brown), 182 
Soviet Russia, 142, 151

Sowing and Reaping (Harper), 168

Spellman, A. B., 176-77, 182

Spingarn, Joel, 11, 98, 104

Spirit House collective, 190

Spy, The (Gorki), 95

Star (Chicago), 110

Stauffer, John, 33-34, 34-35

Steinbeck, John, 97

Steinberg, Jacob, 93

Steven, Nelson, 194-96

Stevens, Wallace, 97

Stewart, James, 197, 198, 200

Stillinger, Jack, 8

Story (magazine), 71, 80

Stowe, Harriet Beecher, 24

structuralism, 186

Sundquist, Eric J., 29

Sun Ra and his Arkestra, 183, 186

Survey Graphic, 35, 42, 101, 151

"Suttee, The" (Oxley), 130

"Sweeney Among the Nightengales"

(Eliot), 106

Taking It to the Streets: The Social Protest Theater of Luis Valdez and Amiri Baraka (Elam), 197

Talemaque, Harold, 129

Tanselle, G. Thomas, 8

Taylor, Cecil, 177

Taylor, Diana, 4, 198

Taylor, Paul, 69

“TCB” (Sanchez), 180

terrain, 127

Text as Process (Bushell), 9

Textual Condition, The (McGann), 7

textualization, 197, 199-205, 202

theater, 184,186

There is Confusion (Fauset), 101, 102

Third World Press, 176, 182, 183, 185, 189, 193-94

"This Harlem" (P. Fisher), 54

“This Must Not Be!” (Collins), 152

Thomas, Lorenzo, 176, 181, 185

"Threnody for a Brown GIrl" (Cullen), 46
Thurman, Wallace, 168, 203-4

Tiger's Eye, The, 112

Tilser, Harry von, 105

Time, 79

"Time Considered as a Helix of SemiPrecious Stones" (Delany), 168

Time Exposures (Frank), 103

Titus, Earl E., 151

"To John Keats, Poet. At Springtime" (Countee Cullen), 47

Tolson, Melvin, 93

Tolstoi Club, 144

Tompkins, Jane, 180

Toomer, Jean, 9, 43, 44, 99, 103, 104, 168

"To the Not Impossible Her" (Cullen), 46

"To the Not Impossible Him" (Millay), 46

Touré, Askia, 181, 184, 185

To Wake the Nations (Sundquist), 29

Townsend, J. Holland, 25

transnational factors, 113-15, 131, 161, 201, 202

Trinidad, 117, 129

"Triumph of Freedom-A Dream"

(Harper), 32

Troupe, Quincy, 199-200

Turgenev, Ivan, 97

Turner, Nat, 29

Twayne (publishing house), 93

Twelve Million Black Voices (Wright), 96

"Two Offers, The" (Harper), 32

typography, 50-52, 196

Ulysses (Joyce), 8, 75

Uncalled, The (Dunbar), 168

Uncle Tom's Cabin (Stowe), 180-81

Uncle Tom's Children (Wright), 71, 80

Unexpected Places (Gardner), 34

"University" (Shapiro), 93

"Unspeakable Things Unspoken: The Afro-American Presence in American Literature" (Morrison), 171

Untermeyer, Louis, 99

USCGS (U.S. Coastal and Geodetic Survey), 140-41, 148 
U.S. Coastal and Geodetic Survey (USCGS), 140-41, 148

U.S. Committee on Public Information, 101

Ussher, Arland, 103

"Value of Race Literature, The" (Matthews), $169-70$

Van der Zee, James, 58

Van Vechten, Carl, 50-56, 59-60, 97, 98, 204

Venus (Rodin), 95

Vesey, Denmark, 28

Vice Society, 103

Vieux, 114

Viking Press, 51, 94, 96-97

"Villanelle of Washington Square" (Roberts), $120-21$

Virgin Islands, 130

visual art, 11. See also individual artists

Vogel, Todd, 19

Voice of the Fugitive (H. Bibb), 20

Voices from Summerland (McFarlane), 128,130

Walker, Alice, 58, 6o

Walker, David, 28

Walker, Margaret, 88, 137

Walrond, Eric, 12, 99

"Warning" (Haynes), 130

Warren, Kenneth W., 10, 11

Washington, Mary Helen, 32

Washington Post (newspaper), 142

Waste Land, The (Eliot), 104-6

"Watermelon Vine, The" ("Lindy Lou") (Allen), 105

Watkins, Barbara, 184

Weary Blues, The (Hughes), 97

Weavers, The (Hauptmann), 95

Weekly Advocate, The (newspaper), 20

Weekly Anglo-African (newspaper), 27, 29

Weekly Review (Hoover), 139, 140

Welsh, Sarah Lawson, 129

Werfel, Franz, 97

West, Cornel, 96
Western World, 109-10, 115, 117, 118, 126, 200

"What are We?" (Grant), 205

"What Shall We Do With the White People," 25

What Was African American Literature? (Warren), 10

"What White Publishers Won't Print" (Hurston), 69

Wheatley, Phillis, 116

"Where 'Separate but Equal' Still Rules" (Connerly), 163

White, Newman Ivey, 112-13, 130

White, Walter, 51, 54, 97, 136

white audiences (readers), 5, 24, 40, 50, $54,58,74,76,78-79,204$

white authors. See also Anglo-Saxons; creoles; individual white authors

Hamilton and, 22

Poetry of the Negro and, 13-15, 111, 115, $116-17,118,125,126,130-31$

publishers and, 94

scholarship and, 2

spirituals and, 113

Tiger's Eye and, 112

White Buildings (Crane), 99

white control/dominant culture. See also postracial era; racism

Black Arts Movement and, 193, 194, 198-99, 200

Larsen and, 59

Passing and, 51, 59

scholarship and, 2, 4-5

typography and, 52

white editors. See also white publishers; individual editors

Cullen and, 41, 44, 45, 47

Douglass and, 33

Hamilton and, 22-25

slave narratives and, 4, 80, 192

Wright and, 68-69

Whitehead, Don, 145

"White House, The" ("White Houses")

(McKay), 42, 44, 122

whiteness, 12, 62, 79, 172, 194. See also double-consciousness theory 
white patrons, 40, 51, 199, 204

white publishers, 40, 100, 199. See also Anglo-Saxons; white editors; specific publishers

Whitfield, James Monroe, 18-19, 21, 29

Whitman, Walt, 2, 29, 30, 32, 116, 188

Whittier, John Greenleaf, 116

Wilde, Oscar, 99

Wiley-Blackwell, 160, 161

Williams, Sherley Anne, 136-37

Williams, William Carlos, 179

Wilson, William J., 23-25

"Winter Twilight, A" (A. W. Grimké), 116

Woman's Home Companion (magazine), 84

women, 31-33, 52-53, 82, 204-5. See also feminism; individual women

Women's Studies International Forum, 59

Woolf, Virginia, 99

Wordsworth, William, 116

Works of James McCune Smith, The (Stauffer, ed.), 33-34

"Work to Unify African People" (mural), 194-96, 195
World and Africa, The (Du Bois), 96

World War I, 101, 143-44

Wright, Richard, 13, 67-89, 96, 136, 149, $168,188-89$

"Wrong Man, The" (Larsen), 168

W. W. Norton, 161. See also Norton Anthology of African American Literature, The

Yale University Press, 3 Yearling, The (Rawlings), 178

Yeats, John Butler, 95

Yeats, W. B., 99, 102-3

Yekl: A Tale of New York (Cahan), 94-95

Yoknapatawpha saga, 72

York Beach (Toomer), 168

Young India (Gandhi), 95

"Youth Speaks," 202

Ziegfeld Follies, 105

Žižek, Slavoj, 74

Zuille, John J., 21

Zweig, Stefan, 97 